\title{
Subcellular Localization \\ Of Nicotiana tabacum \\ TGA Transcription Factors
}

\author{
Dissertation
}

zur Erlangung des Doktorgrades

der Mathematisch-Naturwissenschaftlichen Fakultät

der Georg-August-Universität zu Göttingen

vorgelegt von

Kaloian Iliev Nickolov

aus Sofia, Bulgarien

Göttingen 2002 
D 7

Referentin: $\quad$ Prof. Dr. C. Gatz

Korreferent: $\quad$ PD. Dr. G. Hinz

Tag der mündliche Prüfung: $\quad 30.01 .2003$ 
„... but sooner or later, no matter young or old, a moment will come when the undone will call for you ... "

Evgeni Guljakovski 


\section{Contents:}

1. Introduction ................................................................ 1

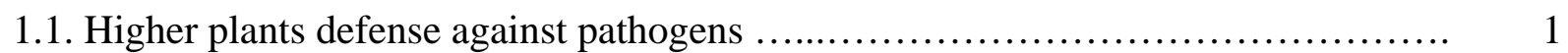

1.2. The role of salicylic acid (SA) in plant defense response .......................... 2

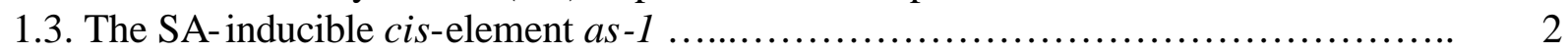

1.4. TGA transcription factors bind to the $a s-1$ element ................................ 4

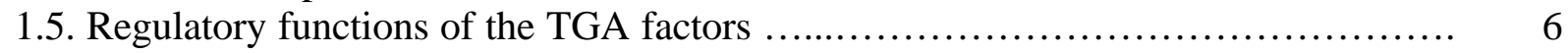

1.6. GFP as an in vivo reported for protein localization .............................. 8

1.7. Aims of the project ......................................................... 11

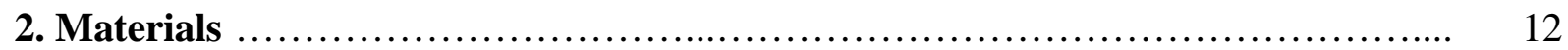

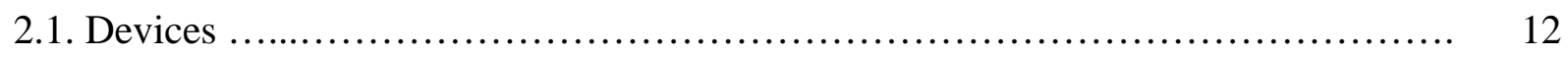

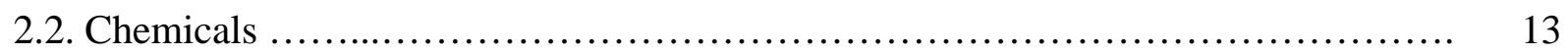

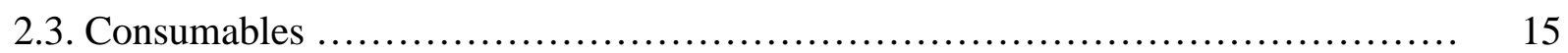

2.4. Buffers, solutions and media ............................................... 15

2.4.1. Buffers ....................................................... 15

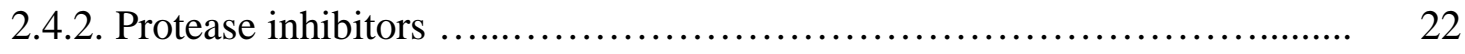

2.4.3. Media and additives ................................................. 23

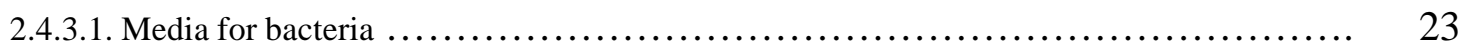

2.4.3.1. Media for plants ......................................................... 24

2.4.4. Additives ............................................................ 25

2.5. Nucleic Acids ............................................................ 25

2.5.1. Oligonucleotides and DNA fragments ............................... 25

2.5.1.1. PCR primers ................................................... 25

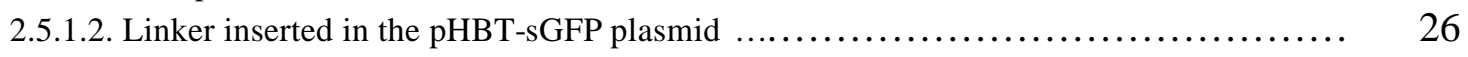

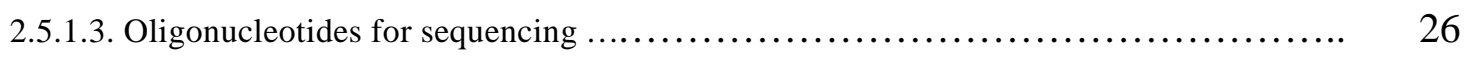

2.5.1.4. as-1-fragment for EMSAs ............................................ 26

2.5.1.5. Hybridization probes ................................................. 26

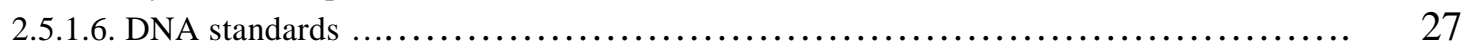

2.5.2. Plasmids .......................................................... 27

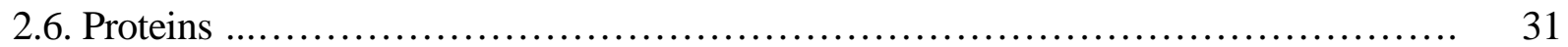

2.6.1. Antibodies .......................................................... 31

2.6.2. Enzymes ........................................................ 31

2.6.3. Protein standards ............................................... 31

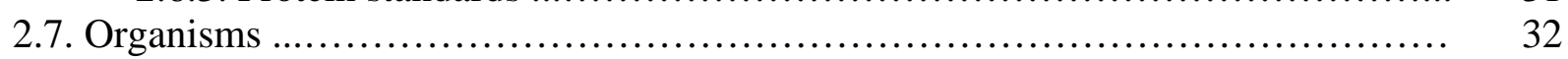

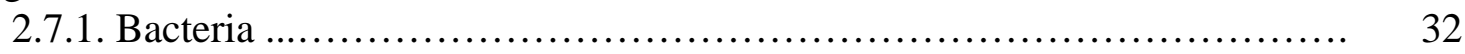

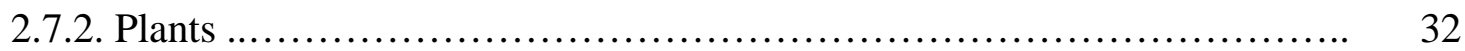

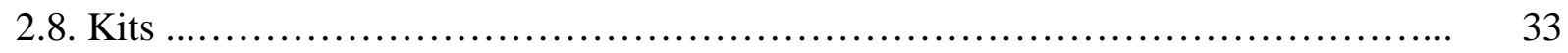

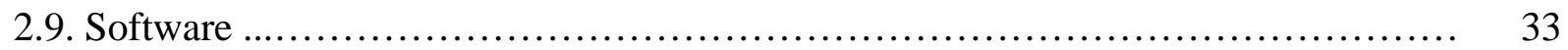

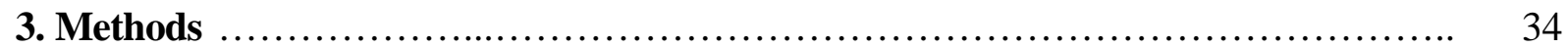

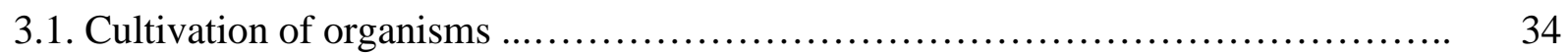

3.1.1. Cultivation of bacteria ............................................... 34

3.1.2. Cultivation of Nicotiana tabacum ....................................... 34

3.2. Isolation, purification, quantification and manipulation of nucleic acids ............... 35

3.2.1. Isolation of nucleic acids ........................................ 35

3.2.1.1. Analyticatscale preparation of plasmid DNA from E. coli ...................... 35

3.2.1.2. Large-scale preparation of plasmid DNA ............................... $\quad 35$

3.2.1.3. Isolation of total RNA from $N$. tabacum leaves ............................... 35 
3.2.1.4. Estimation of the concentrations and purity of nucleic acids ................... 35

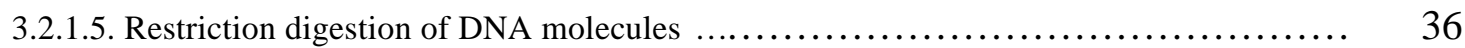

3.2.1.6. Fill-in of 3'-overhangs with Klenow fragment of DNA polymerase I ............... 36

3.2.1.7. Dephosphorylation / phosphorylation of DNA fragments ..................... 37

3.2.1.8. Hybridization of single -stranded into double-stranded oligonucleotides ............. 37

3.2.2. Gel electrophoresis of nucleic acids ............................. 37

3.2.2.1. Separation of DNA fragments on agarose gels $\ldots \ldots \ldots \ldots \ldots \ldots \ldots \ldots \ldots \ldots \ldots \ldots \ldots . \ldots \ldots$

3.2.2.2. Separation of RNA on denaturing agarose gels $\ldots \ldots \ldots \ldots \ldots \ldots \ldots \ldots \ldots \ldots \ldots \ldots . . \ldots \ldots$

3.2.2.3. Recovery of DNA molecules from agarose gels ........................... 38

3.2.3. Ligation of DNA fragments ...................................... 38

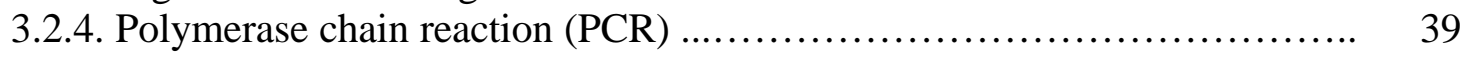

3.2.4.1. Screening bacterial colonies with PCR .................................... 39

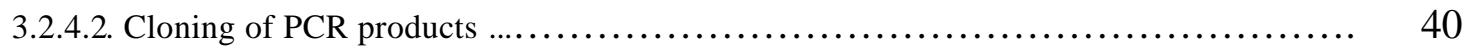

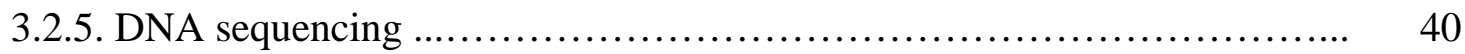

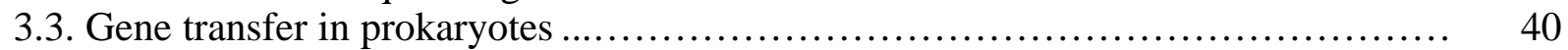

3.3.1. Gene transfer in Escherichia coli ................................. 40

3.3.2. Gene transfer in Agrobacterium tumefaciens .......................... 41

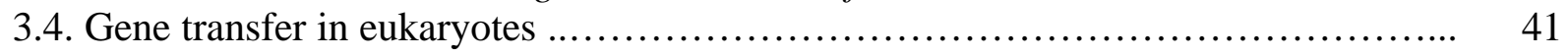

3.4.1. Plasmids for transient expression of diverse fusions of TGA factors with 41 GFP

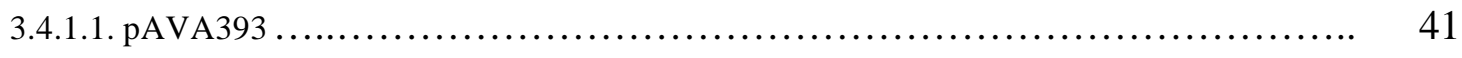

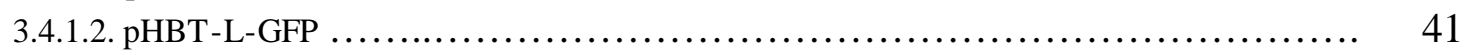

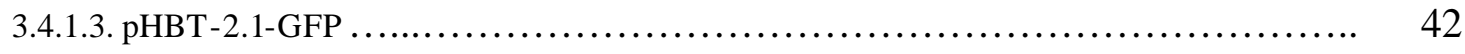

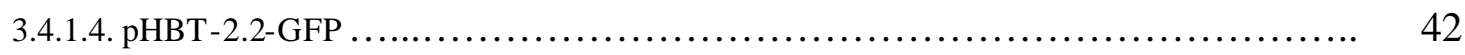

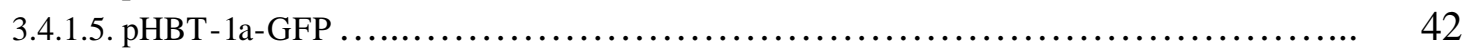

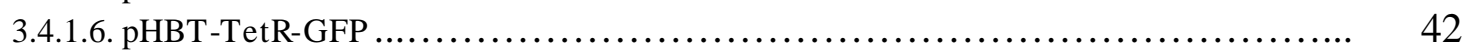

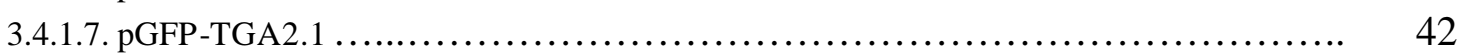

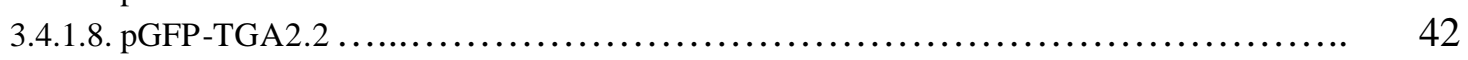

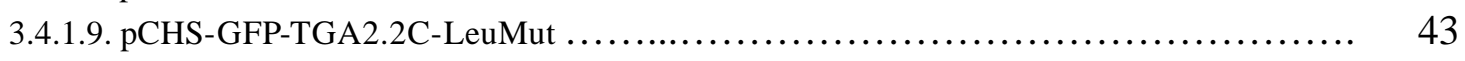

3.4.2. Transient expression of fusion proteins in $N$. tabacum protoplasts ........... 43

3.4.2.1. Preparation of mesophyl protoplasts from $N$. tabacum ......................... 43

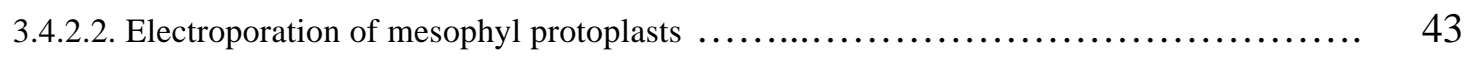

3.4.2.3. Preparation of protoplasts from BY-2 tobacco suspension cells $\ldots \ldots \ldots \ldots \ldots \ldots \ldots \ldots .43$

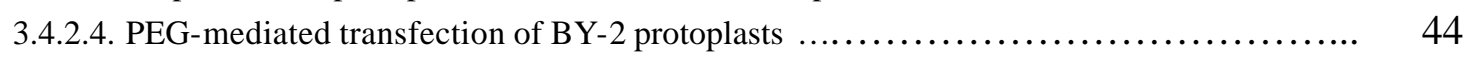

3.4.3. Stable transformation of Nicotiana tabacum .......................... 44

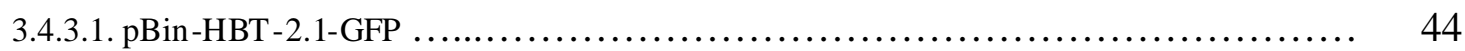

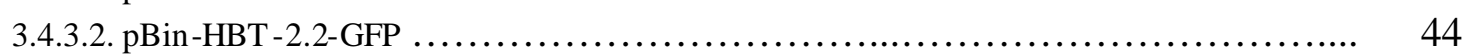

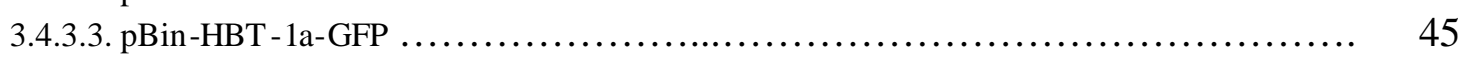

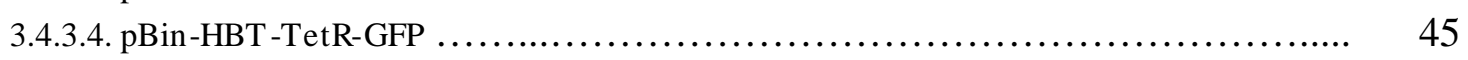

3.4.3.5. Stable transformation of Nicotiana tabacum .............................. 45

3.5.1. Induction of gene expression in Nicotiana tabacum ..................... 46

3.5.2. Infiltration of Nicotiana tabacum leaf discs with Leptomycin B (LMB) ... 46

3.6. Northern blotting ....................................................... 46

3.6.1. Radioactive labeling of DNA probes for hybridization .................. 46

3.6.2. Transfer of RNA onto nylon membranes ............................. 47

3.6.3. Hybridization of Northern blots .................................... 47

3.6.4. Stripping and re-probing of Northern membranes ..................... 47

3.7. Biochemical methods ................................................. 48

3.7.1. Raising polyclonal antiserum against the C-termini of TGA2.1 and $\quad 48$ TGA2.2 
3.7.1.1. Plasmids for inducible expression of GST-2.XC constructs $\ldots \ldots \ldots \ldots \ldots \ldots \ldots \ldots \ldots .48$

3.7.1.2. Expression of recombinant GST-2.XC-fusion proteins in E. coli .................... 48

3.7.1.3. Purification of GST-fused proteins ................................. 48

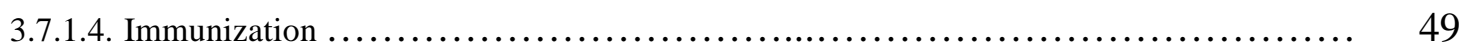

3.7.2. Purifications of the anti-2.XC specific antibodies ...................... 49

3.7.2.1. Coating of $\mathrm{CNBr}$-activated Sepharose with antigen ......................... 49

3.7.2.2. Affinity purification of the anti-2.XC antibodies ........................... 49

3.7.3. Preparation of protein extracts from $N$. tabacum leaves .................. 49

3.7.3.1. Preparation of nuclei ............................................ 49

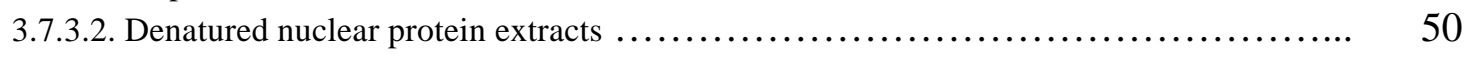

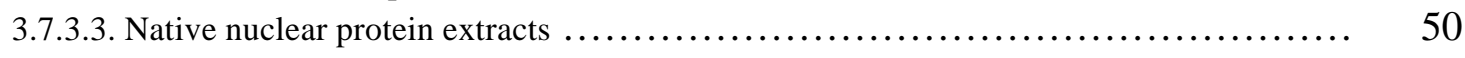

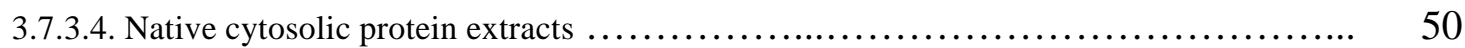

3.7.3.5. Native total cellular protein extracts (Fix Prot) .......................... 51

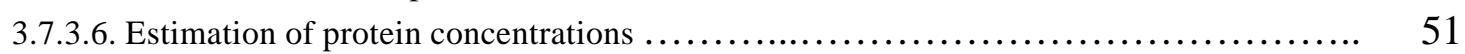

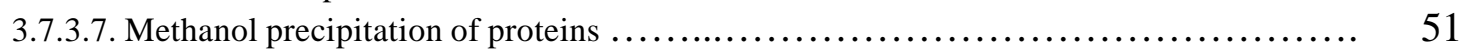

3.7.4. Denaturing SDS-polyacrylamide gel electrophoresis (SDS-PAGE) ........ 51

3.7.5. Coomassie staining of proteins separated on SDS-PAGE ............... 52

3.7.6. Immuno-blotting (Western blot) ............................... 52

3.7.6.1. Semi-dry transfer of proteins onto a PVDF membrane ...................... 52

3.7.6.2. Immuno-detection of the proteins with specific antibodies $\ldots \ldots \ldots \ldots \ldots \ldots \ldots \ldots \ldots \ldots . \ldots 2$

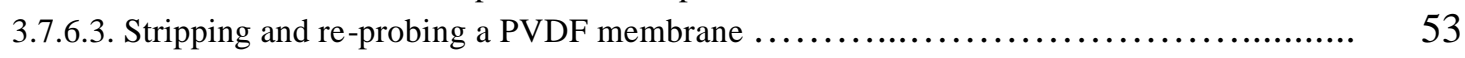

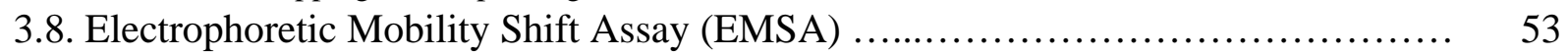

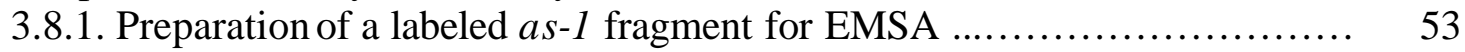

3.8.2. Electrophoretic Mobility Shift Assay (EMSA) ....................... 54

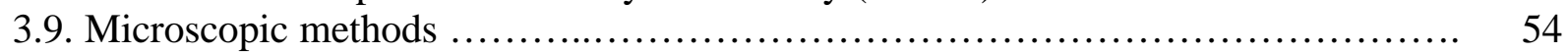

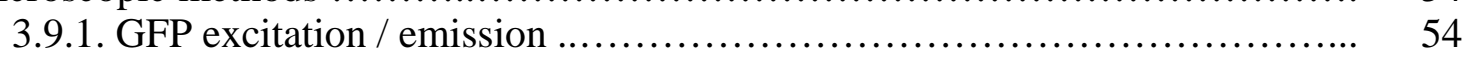

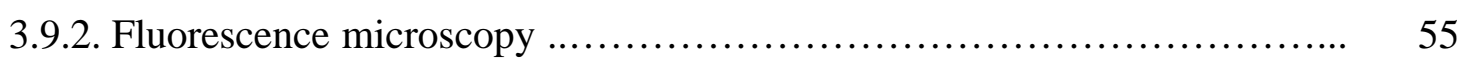

3.9.3. Confocal laser-scanning microscopy (CLSM) ........................ 55

3.9.4. Fluorescence correlation spectroscopy (FCS) ....................... 55

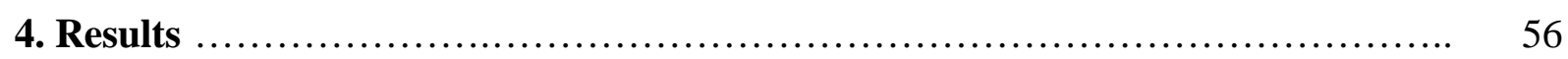

4.1. Construction and transient expression of GFP-tagged TGA factors ................ 56

4.1.1. Construction of plasmids for transient expression of C-terminal fusion $\quad 56$ proteins of the TGA transcription factors with GFP under the control of the HBT promoter

4.1.2. Construction of plasmids for transient expression of $\mathrm{N}$-terminal fusion proteins of the TGA transcription factors with GFP under the control of the CaMV 35S promoter

4.1.3. Construction of GFP fusions with $\mathrm{N}$ - or $\mathrm{C}$-terminal domains of TGA factors

4.1.4. Subcellular sorting of homo-/hetero-dimers ......................... 64

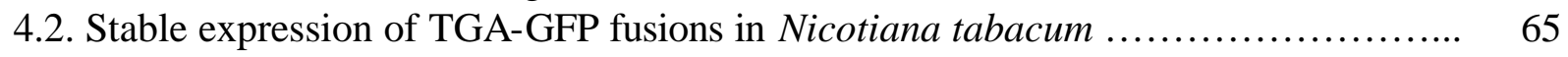

4.2.1. as-1-binding activity in TGA-GFP transgenic plants ................... 67

4.2.2. Influence of TGA-GFP fusions of the SA- or 2,4-D- inducible gene 68 expression

4.2.2.1. Influence of TGA2.X-GFP factors on the level of Nt103 mRNA-/+ SA induction ......

4.2.2.2. Influence of TGA-GFP fusions on the Nt103 m RNA level after SA or 2,4-D treatment . 69

4.2.2.3. Influence of TGA-GFP fusions on the expression level of Nt103 m after SA or 2,4-D 71

treatment in leaves in different developmental stages

4.3. Biochemical studies ............................................... 75

4.3.1. Preparation of antiserum recognizing both TGA2.1 and TGA2.2 C-termini 75 
4.3.2. A cytosolic pool of as-1-binding activity is detectable in EMSAs ......... 77

4.3.3. Western blots of nuclear and cytosolic proteins extracts from leaves ....... 78

4.4. Mobility behavior and fractions of TGA-GFP fusions in different leaf cell types .... $\quad 80$

4.4.1 Characterization of the mobility properties of TGA2.1-GFP in nuclei of 81 leaf cells

4.4.1.1. Mobility of TGA2.1-GFP in nuclei of trichoma cells

4.4.1.2. Mobility of TGA2.1-GFP in nuclei of stomata guard cells $\ldots \ldots \ldots \ldots \ldots \ldots \ldots \ldots \ldots . .63$

4.4.1.3. Mobility of TGA2.1-GFP in nuclei of epidermal cells $\ldots \ldots \ldots \ldots \ldots \ldots \ldots \ldots \ldots \ldots \ldots . . \ldots 5$

4.4.2 Characterization of the mobility properties of TGA2.2-GFP in nuclei of 86 leaf cells

4.4.2.1. Mobility of TGA2.2-GFP in nuclei of trichoma cells ....................... 87

4.4.2.2. Mobility of TGA2.2-GFP in nuclei of stomata guard cells ........................ 88

4.4.2.3. Mobility of TGA2.2-GFP in nuclei of epidermal cells ...................... 90

4.4.3 Characterization of the mobility properties of TGA1a-GFP in nuclei of leaf 92 cells

4.4.3.1. Mobility of TGA1a-GFP in nuclei of trichoma cells $\ldots \ldots \ldots \ldots \ldots \ldots \ldots \ldots \ldots \ldots . .62$

4.4.3.2. Mobility of TGA1a-GFP in nuclei of stomata guard cells ......................... 95

4.4.3.3. Mobility of TGA1a-GFP in nuclei of epidermal cells $\ldots \ldots \ldots \ldots \ldots \ldots \ldots \ldots \ldots \ldots \ldots . . \ldots 7$

4.4.4 Characterization of the mobility properties of TetR-GFP in leaves ........ 98

4.4.4.1. Mobility of TetR-GFP in nuclei of trichoma cells $\ldots \ldots \ldots \ldots \ldots \ldots \ldots \ldots \ldots \ldots \ldots \ldots . . \ldots 9$

4.4.4.2. Mobility of TetR-GFP in stomata guard cells $\ldots \ldots \ldots \ldots \ldots \ldots \ldots \ldots \ldots \ldots \ldots \ldots \ldots \ldots . \ldots \ldots \ldots$

4.4.4.3. Mobility of TetR-GFP in epidermal cells $\ldots \ldots \ldots \ldots \ldots \ldots \ldots \ldots \ldots \ldots \ldots \ldots \ldots \ldots \ldots \ldots \ldots$

4.4.5. Summary of the mobility patterns of the TGA-GFP fusions .............. 103

5. Discussion ............................................................ 104

5.1. Subcellular localization of the GFP-tagged full-length TGA transcription factors ... 104

5.2. Transient expression of separate $\mathrm{N}$ - or C-termini of TGA factors ................. 106

5.3. DNA-binding properties of the TGA-GFP fusion proteins ..................... 107

5.4. Effects of the expression of TGA-GFP fusions on the $a s-1$-mediated gene 109 expression

5.5. Analysis of the mobility properties of the TGA-GFP fusion proteins in nuclei ...... 110

5.6. Outlook ......................................................... 112

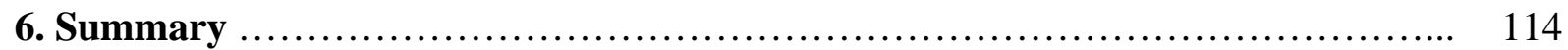

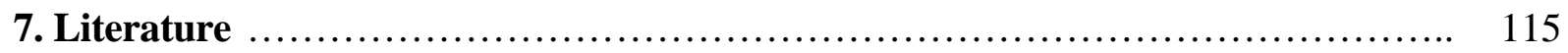

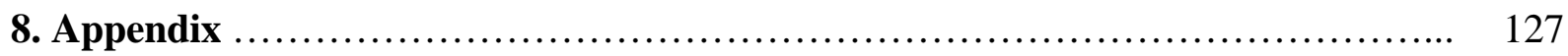

\section{Acknowledgements}

\section{Curriculum vitae}


Abbreviations:

A

A. tumefaciens

a.a.

Ac

Amp

$\mathrm{Amp}^{\mathrm{r}}$

approx.

APS

Ar-laser

as-1

as-103

ASF-1

A. thaliana

ATP

bp

BSA

BY-2

bZIP

${ }^{\circ} \mathrm{C}$

CaMV

cDNA

$\mathrm{Ci}$

CLSM

cpm

C-terminus

cv.

2,4-D

dA

DAPI

dATP

dCTP

ddT

DEPC

dGTP

DMF

DMSO

DNA

DNAse

dNTPs

dsDNA

dT

DTT

dTTP
Ampere

Agrobacteruim tumefaciens

aminoacid(s)

Acetate

Ampicillin

Ampicillin resistance

approximately

Ammonium persulfate

Argon laser

activating sequence-1

as-1-like element in the Nt103 promoter (N. tabacum)

Activating sequence factor 1

Arabidopsis thaliana

Adenosine triphosphate

basepairs

Bovine serum albumin

Bright-Yellow-2 Nicotiana tabacum suspension cells

basic region / leucine-zipper domain

Degree Celsius

Cauliflower Mosaic Virus

copy-DNA from mRNA

Curie

Confocal laser-scanning microscopy

counts per minute

Carboxyl-terminus

Cultivar

2,4-dichlorphenoxyacetic acid

Deoxyadenine

4,6-diamidino-2-phenylindole

2 ' -deoxyadenosine-5' -triphosphate

2'-deoxycytosine -5'-triphosphate

Dideoxythymidine

Diethylpyrocarbonate

2 ' -deoxyguanosine-5' -triphosphate

Dimethylformamide

Dimethylsulfoxide

Deoxyribonucleic acid

Deoxyribonuclease

Deoxynucleotide -5'-triphosphates

Double-stranded DNA

Deoxythymidine

Dithiothreitol

2' -deoxythymidine-5' -triphosphate 


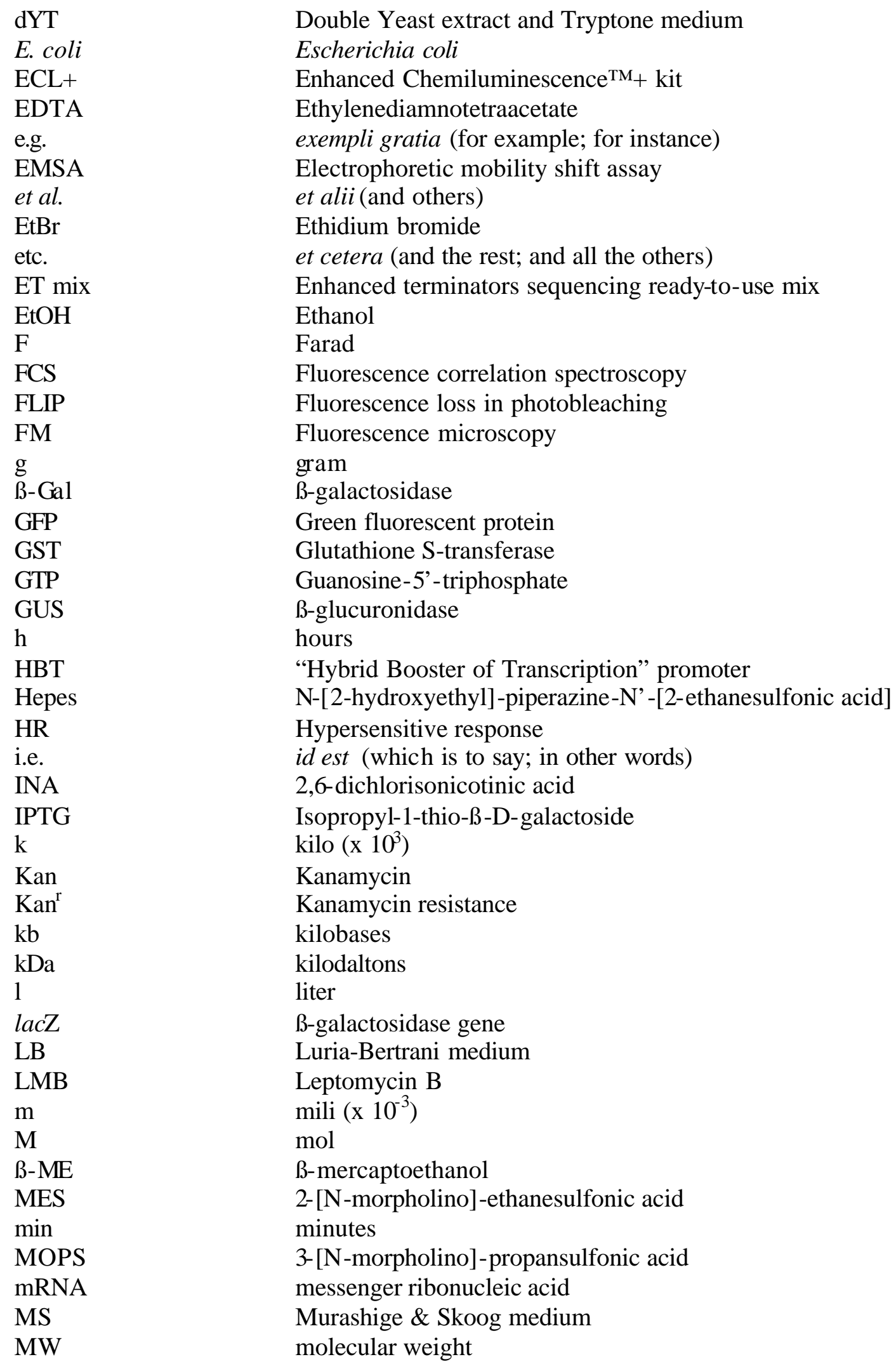




\begin{tabular}{|c|c|}
\hline $\mathrm{n}$ & nano $\left(\mathrm{x} 10^{9}\right)$ \\
\hline NA & Numerical aperture \\
\hline NAA & a-naphthalineacetic acid \\
\hline NES & Nuclear export sequence \\
\hline NLS & Nuclear localization sequence \\
\hline nos & Nopaline synthase \\
\hline $\begin{array}{l}\text { NPR1, nprl } \\
\text { nt }\end{array}$ & $\begin{array}{l}\text { Non-expressor of pathogenesis-related genes } 1 \\
\text { nucleotide }\end{array}$ \\
\hline N. tabacum & Nicotiana tabacum \\
\hline N-terminus & Amino-terminus \\
\hline ocs & Octopine synthase \\
\hline OD & Optical density \\
\hline $\mathrm{o} / \mathrm{n}$ & overnight \\
\hline $\mathrm{pA}$ & Polyadenylation signal \\
\hline PAA & Polyacrylamide \\
\hline PCR & Polymerase chain reaction \\
\hline PEG & Polyethyleneglycol \\
\hline $\mathrm{pH}$ & Negative decimal logarithm of the proton concentraction \\
\hline PMSF & Phenylmethylsulfonylfluoride \\
\hline poly-dIdC & Polydeoxyinosine-deoxycytosine \\
\hline PR & Pathogenesis-related \\
\hline PVDF & Polyvinylendifluoride \\
\hline PVP & Polyvinylpolypyrolidone \\
\hline RNA & Ribonucleic acid \\
\hline RNAse A & Ribonuclease A \\
\hline ROS & Reactive oxygen species \\
\hline rpm & rotations per minute \\
\hline RT & Room temperature \\
\hline s. & see \\
\hline SA & Salicylic acid \\
\hline sail & salicylic-acid-insensitive 1 \\
\hline SAR & Systemic acquired resistance \\
\hline SDS & Sodiumdodecylsulfate \\
\hline $\begin{array}{l}\text { SDS-PAGE } \\
\text { sec }\end{array}$ & $\begin{array}{l}\text { Denaturing SDS-polyacrylamide electrophoresis } \\
\text { seconds }\end{array}$ \\
\hline SIPK & Salicylic-acid-inducible protein kinase \\
\hline snil & suppressor of npr-1, inducible \\
\hline SNN & Samsun NN tobacco cultivar \\
\hline $\mathrm{SSC}$ & Strandard saline citrate buffer \\
\hline ssDNA & Single-stranded DNA \\
\hline TAE & Tris-acetate-EDTA buffer \\
\hline $\mathrm{T}_{\mathrm{ann}}$ & Annealing temperature \\
\hline$T a q$ & Thermophylus aquaticus \\
\hline TBE & Tris-borate-EDTA buffer \\
\hline TEMED & $\mathrm{N}, \mathrm{N}, \mathrm{N}^{\prime}, \mathrm{N}^{\prime}$-tetramethylethylenediamine \\
\hline TetR & Tetracycline repressor \\
\hline
\end{tabular}




\begin{tabular}{|c|c|}
\hline TMV & Tobacco Mosaic Virus \\
\hline Tris & Tris-(hydroxymethyl)-aminomethane \\
\hline TSR & Template suppress reagent \\
\hline $\mathrm{U}$ & Unit (enzyme activity) \\
\hline $5^{\prime}$-UTR & 5 - untranslated region \\
\hline UV & Ultraviolet light \\
\hline $\mathrm{V}$ & Volt \\
\hline vol & volume \\
\hline$\%(\mathrm{v} / \mathrm{v})$ & volume \% (volume-per-volume) \\
\hline $\mathrm{W}$ & Watt \\
\hline wt & Wild-type \\
\hline$\%(\mathrm{w} / \mathrm{v})$ & Weight \% (weight-per-volume) \\
\hline $\mathrm{X}-\mathrm{Gal}$ & 5-chlor-4-brom-3-indolyl- $\beta$-D-galactopyranoside \\
\hline $\mathrm{Y} 2 \mathrm{H}$ & Yeast two-hybrid system \\
\hline a & Antiserum \\
\hline$?$ & Wavelength, bacteriophage Lambda \\
\hline$\mu$ & micro $\left(\times 10^{-6}\right)$ \\
\hline $\mathrm{O}$ & Ohms \\
\hline
\end{tabular}

Aminoacid one- and three-letter codes:

$\begin{array}{llllll}\text { A } & \text { Ala } & \text { Alanine } & \text { M } & \text { Met } & \text { Methionine } \\ \text { C } & \text { Cys } & \text { Cysteine } & \text { N } & \text { Asn } & \text { Asparagine } \\ \text { D } & \text { Asp } & \text { Aspartic acid } & \text { P } & \text { Pro } & \text { Proline } \\ \text { E } & \text { Glu } & \text { Glutamic acid } & \text { Q } & \text { Gln } & \text { Glutamine } \\ \text { F } & \text { Phe } & \text { Phenylalanine } & \text { R } & \text { Arg } & \text { Arginine } \\ \text { G } & \text { Gly } & \text { Glycine } & \text { S } & \text { Ser } & \text { Serine } \\ \text { H } & \text { His } & \text { Histidine } & \text { T } & \text { Thr } & \text { Threonine } \\ \text { I } & \text { Ile } & \text { Isoleucine } & \text { V } & \text { Val } & \text { Valine } \\ \text { K } & \text { Lys } & \text { Lysine } & \text { W } & \text { Trp } & \text { Tryptophane } \\ \text { L } & \text { Leu } & \text { Leucine } & \text { Y } & \text { Tyr } & \text { Tyrosine }\end{array}$

Nucleotide code:
A Adenine
$\mathrm{R} \quad \mathrm{A}$ or $\mathrm{G}$ (purine)
C Cytidine
$\mathrm{Y} \quad \mathrm{C}$ or $\mathrm{T}$ (pyrimidine)
G Guanine
$\mathrm{K} \quad \mathrm{G}$ or $\mathrm{T}$ (keto-base)
$\mathrm{T}$ Thymidine
$\mathrm{M} \quad \mathrm{A}$ or $\mathrm{C}$ (amino-base)
B C, G or T
D $A, G$ or $T$
$\mathrm{S} \quad \mathrm{G}$ or $\mathrm{C}$
$\mathrm{H} \quad \mathrm{A}, \mathrm{C}$ or $\mathrm{T}$
W A or T
$\mathrm{V} \quad \mathrm{A}, \mathrm{C}$ or $\mathrm{G}$
$\mathrm{N} \quad \mathrm{A}, \mathrm{C}, \mathrm{G}$ or $\mathrm{T}$ 


\section{Introduction}

\subsection{Higher plants defense against pathogens}

Higher plants defend themselves against the attacks of pathogenic bacteria, viruses and fungi by a variety of strategies. The passive defense includes mainly mechanical hindrances (e.g. rigid cell walls, cuticles, etc.) and production of substances with antimicrobial effects. If the pathogen organisms are able to surmount those barriers and come into contact with the cells, resistant plants often are able to recognize the invading pathogen via the so-called "gene-for-gene" interactions (Bent, 1996; Ellis and Jones, 1998) between products of pathogen avirulence (Avr) genes and plant host receptors, many of which are encoded by disease resistance $(R)$ genes. This recognition usually triggers rapid local cell death of the plant cells at the site of the infection (hypersensitive response, HR) in order to destroy the pathogen organisms and to prevent the ir further spreading in the whole plant (for review see Yang et al., 1997 and Delaney, 1997). The fast and timely recognition of the pathogen as well as a subsequent effective activation of the defense mechanisms determine the resistance or the susceptibility of the plant against the attacking pathogen; if the $a v r$ gene of the pathogen or the corresponding $R$ gene of the plant are missing or not functional, the plant defense is activated quite late or not activated at all, leading to a spreading of the (virulent) pathogen in the (susceptible) plant system and resulting in severe damages to the plant or even its death. Despite this "racespecific" resistance plant species often display a more general "non-host-specific" resistance; similar processes seem to be involved in both mechanisms. One of the earliest reactions (within minutes) after pathogen attack is a rapid increase of reactive oxygen species (ROS) at the infection site, known as "oxidative burst" (Sutherland, 1991); this burst occurs regardless of whether the plant eventually resists or succumbs to the pathogen infection; only in resistant plants a second sustained increase of ROS develops a few hours later (Dempsey et al., 1999). Elevated levels of ROS are suggested to be involved in the direct killing of the pathogen (Peng and Kuc, 1992), in cross-linking and lignifications of the cell walls (Bradley et al., 1992; Bolwell et al., 1995) and also as messengers for the activation of defense genes (Levine et al., 1994; Garreton et al., 2002). Other early responses include ion fluxes, activation of $G$ proteins and protein kinases (Blumwald et al., 1998), activation of enzymes from the phenylpropanoid pathway (e.g. phenylalanine-ammonia-lyase, PAL) which are involved in synthesis of salicylic acid (SA) and also of phytoalexins, activation of glutathione-S-transferases, etc. Few hours or days after these fast early reactions plants activate additional defense mechanisms, which in many cases lead to the development of hypersensitive reactions, characterized by local lesions at the sites of infection due to localized programmed cell death (Lam et al., 2001). Just prior or concurrent with the development of HR is the activation of a variety of pathogenesis-related (PR) genes encoding for hydrolases and other proteins with yet unknown functions (Kombrink and Somssich, 1997), some of which are also expressed later in the systemic non-inoculated leaves of the plant (Ward et al., 1991). This expression of PR proteins in non-infected leaves is concomitant with the development of a systemic acquires resistance (SAR) in the plants, due to which plants that survive the primary pathogen infection become less susceptible to secondary infections with the same and also with other pathogens (Ryals et al., 1996). 


\subsection{The role of salicylic acid (SA) in plant defense responses}

Salicylic acid (SA) is an important signaling molecule in the local (HR) and in the systemic (SAR) plant response against pathogen attacks (for review see Dempsey et al., 1999). More than 20 years ago (White, 1979) it was discovered that tobacco leaves incubated with salicylic acid or acetylsalicylic acid (aspirin) inc rease their resistance to infection with tobacco mosaic virus (TMV). Subsequent studies had shown that exogenous SA treatment enhances plant resistance to many bacterial, fungal and viral pathogens and induces PR gene expression (Malamy et al., 1992) in the same manner as they are expressed during SAR in Nicotiana tabacumand Arabidopsis thaliana (Ward et al., 1991; Uknes et al., 1993a). In inoculated leaves of the TMV-resistant tobacco cultivar Xanthi-nc in parallel to an activation of the synthesis of PR proteins SA levels increased 20-50-fold 24 hours after infection and continued to rise for up to 8 days; in the upper non-inoculated leaves a 10-fold rise in SA concentration correlated with accumulation of PR transcripts was also detected (Malamy et al., 1990). Further information that SA is necessary for PR expression and SAR came from experiments with plants expressing a bacterial salicylate hydroxylase (encoded by the nahG-gene) which converts SA to inactive cathehol; those plants were unable to express PR genes and to mount SAR in non-inoculated leaves (Gaffney et al., 1993). When a bacterial enzyme converting chorismate to SA in a two-step-process was expressed in tobacco plants, that resulted in a constitutive accumulation of SA leading to higher resistance against pathogens and constitutive expression of some PR genes (Verberne et al., 2000); these effects also were observed in Arabidopsis mutants with constitutive high SA levels (see Yang et al., 1997). Besides PR, several other groups of plant defense genes are also activated by SA; the SA inducible genes can be classified into two groups depending on when they are expressed after stimulation (Durner et al., 1997):

- Immediate-early-expressed genes - their activation is independent of de novo protein synthesis i.e. all regulatory factors for their expression seem to be already present at the moment of stimulation with SA; examples from this group are tobacco genes encoding for glutathione-S-transferases (Nt103-1, Nt103-35, Nt107-2, Boot et al., 1993) and for glucosyltransferases (IEGT, Horvath and Chua, 1996)

- Late-expressed genes - their activation is dependent on the de novo synthesis of proteins and cycloheximide (CHX, an inhibitor of protein synthesis) blocks their expression; examples from this group are the $P R$ genes (Uknes et al., 1993b)

\subsection{The SA-inducible cis-element as-1}

The promoters of genes involved in plant defense often contain cis-elements, which confer SA- or/and pathogen-inducible gene expression (summarized in Yang et al., 1997). One group of those cis-elements, known as activating sequence-1 (as-1)-like elements is present in the promoters of many tobacco early genes e.g. Nt103-1, Nt103-35, IEGT, etc. (Droog et al., 1995; van der Zaal et al., 1996; Horvath et al., 1998) and late 
genes e.g. PR-1a (Strompen et al., 1998). The as-1 element was originally identified by analysis of deletion derivatives of the $35 \mathrm{~S}$ promoter from Cauliflower Mosaic Virus (CaMV). This promoter mediates constitutive high expression in almost all plant tissues (Odell et al., 1985) while the region upstream from the transcription start +1 until -90 was able to confer reporter gene expression only in root tips, apical meristems, protoplasts and calli (Fromm et al., 1989; Benfey et al., 1989; Liu and Lam, 1994). These tissue-specific activation properties had been assigned to a $20 \mathrm{bp}$-long stretch (located from -82 to -62 position) containing two TGACG imperfect palindrome motifs (Fig. 1.1) $34 \mathrm{bp}$ upstream from the TATA box of the CaMV $35 \mathrm{~S}$ promoter.

\section{5'-TGACGTAAGGGATGACGCAC-3'}

Fig. 1.1. Sequence of the as- 1 -element from the CaMV $35 \mathrm{~S}$ promoter

Besides as-1-like elements in the promoters of the pathogen-induced genes and in the CaMV 35S promoter, as-1-like elements are also found in other plant viruses, plantpathogenic bacteria and in the Agrobacterium tumefaciens' T-DNA in the promoters of opine-synthase genes e.g. nos (nopaline synthase), ocs (octopine synthase), mas (manopine synthase), etc. (Bouchez et al., 1989).
CaMV 35S promoter
N. tabacum Nt103-1
N. tabacum Nt103-35
A. thaliana GST6
A. tumefaciens nos
A. tumefaciens ocs
A. tumefaciens mas
N. tabacum PR-1a
A. thaliana $P R-1$
an ideal as- 1 element

$\begin{array}{lcl}\text { TGACGTAA } & \text { ggga } & \text { TGACG CA } \\ \text { ATAGCTAA } & \text { gtgc } & \text { TTACGTAT } \\ \text { TTAGCTAA } & \text { gtgc } & \text { TTACGTAT } \\ \text { TTATGTCA } & \text { ttga } & \text { TGACGACC } \\ \text { TGAGCTAA } & \text { gcac } & \text { ATACGTCA } \\ \text { AAACGTAA } & \text { gcgc } & \text { TTACGTAC } \\ \text { TGACGTAA } & \text { gtat } & \text { CCTAGTCA } \\ \text { ACGTCATC } & \text { gaga } & \text { TGACGGCC } \\ \text { TGACGTGT } & \text { ttct } & \text { CTACGTCA } \\ \text { TGACGTCA } & ---- & \text { TGACGTCA }\end{array}$

Fig. 1.2. as-1-like elements found in different promoters

Studies with the nos-promoter (An et al., 1990) and with isolated as-1-like elements fused to a minimal promoter had shown that as-1-like elements are inducible by auxin and also by salicylic acid and methyl jasmonate (Kim et al., 1993; Liu and Lam, 1994; Qin et al., 1994; Xiang et al., 1996). Furthermore, in carrot protoplasts activation abilities showed not only the biologically active forms of auxins and SA but also inactive structural homologues of them (Ulmasov et al., 1994) known to have some phytotoxic effects. As long as the promoters of many glutathione-S-transferase genes contain as-1like elements and those enzymes are known to detoxificate cytotoxic substances and to protect cells from oxidative damages (Levine et al., 1994), it was suggested that as-1-like elements might be involved in signal transduction responses induced by chemical stress; one kind of which can be the burst of ROS in plant defense reactions (see 1.1). 
Some functional studies of as-1-like elements in promoters controlling early defense genes had shown that the induction kinetics of an isolated as-1 element stimulated with SA, auxin of methyl jasmonate are the same as with the promoter of the Nt103-35 gene (Xiang et al., 1996; Niggeweg et al., 2000b) and do no depend on de novo protein synthesis (Liu and Lam, 1994; Qin et al., 1994). After deleting of the as-1-like elements from the promoters of NT103-1 and Nt103-35, the genes did not respond anymore to SA and auxin (Droog et al., 1995). as-1-like motifs are also involved in the SA-inducible regulation of promoters of late genes. The expression of the tobacco $P R-1 a$ gene encoding for an acidic extra-cellular protein of $14 \mathrm{kDa}$ with yet unknown function is increased 1000-10000 folds after SA treatment or in TMV-infected leaves (Ward et al., 1991; Uknes et al., 1993b), but mutations in the as-1-like element definitely reduce the inducibility of gene by stimuli or infections (Strompen et al., 1998).

Many results suggest that there might be some differences in the SA-dependent regulation of promoters of early and of late genes and also of isolated as-1-like elements. The transient induction from promoters of immediately-early genes e.g. Nt103-1 and from the CaMV $35 \mathrm{~S}$ promoter reaches a maximum at approx. 2-3 hours, while the SAinduced expression of late genes e.g. $P R-1 a$ reaches a maximum at 24 hour and is dependent on de novo protein synthesis, indication that an additional regulatory element (probably a transcription factor which binds to another cis-element in the $P R-1 a$ promoter) or more regulatory proteins have to be synthesized after the stimulation event. As long as auxin and methyl jasmonate have no effect on the expression of PR-genes it seems that the expression of these regulatory elements is specifically induced by SA either by its increased levels after pathogen attack or when exogenously applied.

\subsection{TGA transcription factors bind to the as-1 element}

The plant trans-acting factor able to bind to the as-1-element was named initially "activating sequence factor 1" (ASF-1); it was detected in nuclear protein extracts as a DNA-binding activity able to interact with the -75 region of the CaMV $35 \mathrm{~S}$ promoter (Lam et al., 1989). The corresponding as-1-binding activity in total cellular protein extracts was referred to as "salicylic acid response protein" (SARP, Jupin and Chua, 1996). The first as-1-binding protein TGAla was isolated from a tobacco cDNA library with a labeled TGACG-containing DNA probe (Katagiri et al., 1989). This protein belongs to the class of bZIP transcription factors (Lamb and McKnight, 1991) which are characterized by a basic DNA-binding region in proximity of an a-helical leucine-rich region ("leucine zipper") responsible for the formation of dimers, which is the active DNA-binding form of those bZIP proteins (Landschulz et al., 1988). Besides the bZIP domain, TGA1a has one acidic $\mathrm{N}$-terminal domain and one glutamine-rich Cterminal domain with activation potentials (Neuhaus et al., 1994; Pascuzzi et al., 1998) and a Cterminal dimer-stabilizing domain (Katagiri et al., 1992). Subsequently a number of cDNAs encoding for proteins homologous to TGA1a had been isolated from different plant species ( $N$. tabacum, A. thaliana, S. tuberosum, V. faba, Z. mays, etc.); during their isolation they had been given the names TGA factors, ocs-binding factor (OBF); masbinding factor $(\mathrm{MBF})$ or histone promoter-binding protein $(\mathrm{HBP})$; bday they are all 
summarized and referred to as TGA factors. In A. thaliana seven members of this group had been described so far and four additional genes encoding for TGA factors were found during the Arabidopsis Genome initiative, which had not yet been characterized. Based on homologies in the amino acid sequences, these factors have been grouped in three classes: class I - TGA1 and TGA4, class II - TGA 2, TGA 5 and TGA6, and class III TGA3. The gene PERIANTHIA (Chuang et al., 1999) encoding for another A. thaliana TGA factor was identified from a mutant that showed penta-symmetry of the flowers instead of the wild type tetra-symmetry. The $\mathrm{C}$-terminus of this protein is similar to the ones of the class II factors, but due to its long N-terminus (167 a.a. compared to 48 a.a. of TGA2) it had been grouped in its own class IV.

In $N$. tabacum so far five TGA factors had been identified, four of which according to some homology with the TGA factors from A. thaliana are grouped in two classes TGA1a and PG13 (Fromm et al., 1991) are members of class I and TGA2.1 and TGA2.2 (Niggeweg et al., 2000a) form the tobacco class II of TGA factors. The fifth known tobacco TGA factor (TGA7, Schiermeyer, 2001) reminds of PERIANTHIA from Arabidopsis - bZIP and Cterminus similar to TGA factors class II, but the long $\mathrm{N}$ terminus (217 a.a.) shows no similarity to PERIANTHIA or other TGA proteins.

Interactions between DNA-binding proteins (e.g. ASF-1/SARP) and their DNA targets can be studied by gel-retardation assays (known also as "electrophoretic mobility shift assays", EMSA), in which proteins are incubated with a radioactively labeled DNA fragment; the interaction DNA-protein complexes are separated in native gels according to their molecular weight and visualized by autoradiography. In case when a specific antibody against a DNA-binding protein is added in the binding reaction, the complexes that are formed are additionally retarded in their mobility and are detected further higher ("super-shifted"). Despite the fact that all TGA factors are able to bind as-1-like motifs, so far only TGA2 in Arabidopsis and TGA2.2 and TGA2.1 in tobacco were detected in supershift analysis as members of the ASF-1 complex in leaves. TGA2 in leaves of $A$. thaliana was estimated to be approx. $50 \%$ of the AFS-1 activity (Lam and Lam, 1995); in tobacco leaf extracts TGA2.2 and TGA2.1 were shown to be respectively about $80 \%$ and $10 \%$ of the ASF-1 complex (Niggeweg et al., 2000b).

bZIP transcription factors bind their target DNA sequences in the form of homo- or hetero-dimers. This was demonstrated for TGA factors in studies where due to deletions (Rieping et al., 1994, Miao and Lam, 1995) or modifications (Niggeweg et al., 2000b, Pontier et al., 2001) of the basic domain TGA factors were not able to bind DNA anymore which resulted in reduction of the ASF-1 activity and a decrease of transcription from the as-1 element; as long as the TGA factors with deleted basic domain (tobacco PG13 and TGA 3 from Arabidopsis) were not shown to be a component of ASF-1/SARP it was concluded that the factors are able to form in this case inactive heterodimers with tobacco TGA2.2 or TGA2.1, respectively with TGA2 from A. thaliana.

In binding experiments with in vitro translated TGA1, TGA2, TGA3 and TGA5 incubated with DNA fragments containing two TGACG motifs (e.g. as-1-like) or a single TGACG motif (e.g. hex) differences in the binding preferences of the TGA factors were 
detected. In contrast to the other above mentioned TGA factors, TGA2 was not able to bind to a single TGACG element but only to two TGACG motifs (Lam and Lam, 1995). Such preference was also shown for TGA2.1 from tobacco (Niggeweg et al., 2000a). In gelshifts with the as- 1 -element incubated with nuclear or total protein extracts two shifted bands were detected (Lam et al., 1989), interpreted as a single occupation of the as-1element by one TGA dimer (the faster-running lower band) and a double occupation by two TGA dimers (the slower-running upper band) as presented on Fig. 1.3:

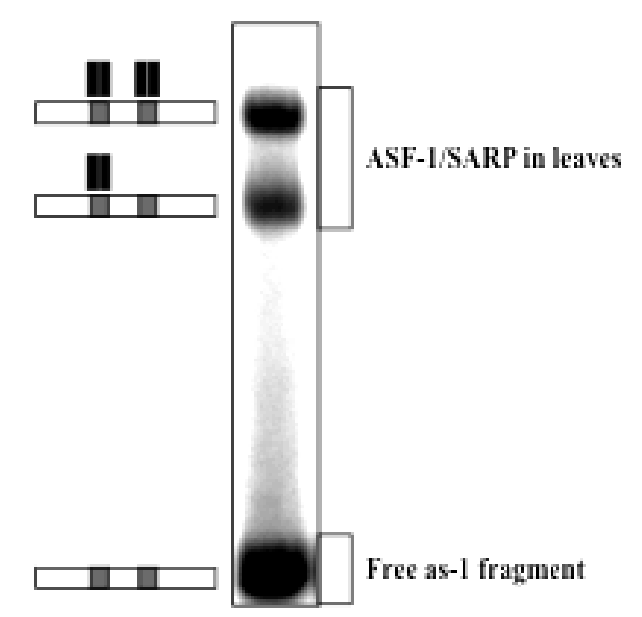

Fig. 1.3. ASF-1/SARP binding to the as-1-element

The picture presents a gel retardation assay with a labeled $a s-1$ fragment and leaf protein extract; on the left side the interpretation of the bands is given schematically where grey boxes indicate TGACG motifs and a couple of black boxes stand for TGA dimer; the upper band on the gelshift is due an occupation of the as-1element by two TGA dimers; the middle one is an as-1-frgament occupied by a single TGA dimer and the lower one is the free-running as-1-element. The DNA-binding protein complex is known as "ASF-1" in nuclear preparations and as "SARP" in total protein extracts.

\subsection{Regulatory functions of the TGA factors}

A lot of evidence suggests a role of the ASF-1/SARP complexes in the regulation of the inducible transcriptional activity from as-1-like elements. An increased binding activity of ASF-1 to an as- 1 -element with two perfect palindrome motifs correlated with an increased SA inducibility of this element (Qin et al., 1994), while mutations in the CaMV $35 \mathrm{~S}$ (-90) promoter which hindered its activity also reduced the binding of ASF-1 to it (Lam et al., 1989). Transgenic plants expressing trans-dominant negative TGA mutants with a mutated or deleted DNA-binding domain had also decreased as-1- activity in vivo and reduced ASF-1 activity in vitro (Rieping et al., 1994; Miao and Lam, 1995; Niggeweg et al., 2000b; Kegler, 2001). Over-expression of TGA2.1 and TGA2.2 in tobacco resulted in stronger ASF-1/SARP activity and an increased inducibility of the glutathione-S-transferase Nt103-35 gene by SA, auxin and methyl jasmonate (Niggeweg et al., 2000b; Kegler, 2001). Treatment of tobacco leaves with SA was shown to increase the binding activity of ASF-1/SARP (Jupin and Chua, 1996; Stange et al., 1997). 
As long as the as-1-like elements in the promoters of plant defense genes are not constitutively active, the proteins involved in the transcription from such promoters (e.g. the TGA transcription factors) obviously undergo some kind of regulation. Objects of this regulation might be the DNA-binding or the activation properties of the TGA factors as well as their compartmentalization between the nucleus and the cytoplasm of the plant cell. This modulation of the properties of the TGA factors can be achieved mechanically by interactions with other proteins or by post-translational modifications e.g. phosphorylation of the TGA factors or of their interacting partner(s). Phosphorylation was shown to play a role in the DNA-binding affinity of ASF-1/SARP - treatment of protein extracts from SA-induced leaves with alkaline phosphatase significantly reduced the binding activity, while the addition of ATP to nuclear protein extracts from noninduced leaves lead to an increase of the binding activity to the $a s$ - 1 -element (Stange $e t$ al., 1997); in neither case direct phosphorylation or dephosphorylation of the TGA factors could be shown, therefore it is more probable that the phosphorylation status of a TGA-factors-interacting protein is changed upon induction. This hypothetical protein more likely plays a negative role in the regulation of the DNA-binding properties of the TGA factors as long as treatment of protein extracts from non-induced leaves with formamide and detergents resulted in stronger binding of ASF-1/SARP to the as-1element (Jupin and Chua, 1996) probably due to a dissociation of this inhibitor (named by the authors "SA-inhibitor", $S A I$ ) from the TGA factors or their dimers.

By co-immunoprecipitation experiments with extracts from tobacco "bright-yellow-2" (BY-2) cell suspension culture with anti-TGA1a-serum Johnson and colleagues had identified a TGA1a-interacting protein of apparent molecular size of $120 \mathrm{kDa}$ (p120) which in non-induced state hindered the binding of TGAla to the as-1-element in the promoter of Nt103-35 by interacting reversibly with the Cterminus of TGAla. Upon xenobiotic stress (stimulation with the synthetic auxin 2,4-dichlorophenoxyacetic acid, 2,4-D) the TGA1-p120 interaction was abolished which resulted in a transient activation of the expression of Nt103-35 but it was detectable again when the GST expression went back down to basal level. This hindrance effect of p120 on the DNA-binding of TGA1a was further studied with a transiently expressed C-terminal deletion mutant of TGAla with an exchanged leucine zipper from the mammalian bZIP transcription factor CREB. This construct (TGA1a-CREB?CT) significantly enhanced the as-1-dependent transcription under non-inducing basal conditions. That data indicates that the changes in the rate of transcription of Nt103-35 are inversely correlated with the degree of association between TGA1 and p120 (J ohnson et al., 2001).

A key SAR-regulatory protein named "non-expressor of pathogenesis-related genes" (NPR1) also known as "non-inducible immunity" (NIM1) and "salicylic acid-insensitive" (SAI1) was identified in A. thaliana from a mutant which was not able to express PRgenes upon stimulation with SA and was also compromised in SAR (Cao et al., 1994). The NPRl gene encodes for a $65 \mathrm{kDa}$ protein with four ankyrin repeats and a BTB/POZ ("broad-complex, tram track, bric-a-brac/poxvirus, zinc finger") domain; both motifs are known to be involved in protein-protein interactions (Cao et al., 1997; Ryals et al., 1997). Over-expression of NPRI in Arabidopsis leads to an increased resistance against various pathogens (Cao et al., 1998), while the isolated recessive allelic nprl-mutants are more 
susceptible to pathogen attacks than wild-type plants (Cao et al., 1994); interestingly in the nprl-1 mutant background a mutation of the SNI1 gene ("suppressor of nprl-1, inducible") which encodes for a $49 \mathrm{kDa}$ leucine-rich protein restored the $P R-1$ expression and SAR to nearly wild-type levels ( $\mathrm{Li}$ et al., 1999). Using a fusion protein between NPRI and the green fluorescent protein (GFP, see 1.6) Kinkema et al., 2000 could show in vivo that NPRI accumulates in the nucleus in response to activators of SAR. In a yeast "two-hybrid" system NPRl was able to interact with the C-termini of TGA factors with a TGA3>TGA2>TGA5>TGA6>TGA1 decreasing affinity; between TGA4 and NPR1 no interaction was detected (Zhou et al., 2000). NPRl was shown to enhance in vitro the DNA-binding properties of TGA2 (Despres et al., 2000); in vivo this interaction results in an activation of the SA-mediated gene expression (Fan and Dong, 2002). Based on this data, it seems that NPR1 acts as a positive regulator of PR-gene expression by enhancing the DNA-binding affinity of TGA factors upon stimulation probably by replacing a negative regulator of the TGA factors (probably SNI1); this TGA-activating interaction was shown to take place in the nucleus (Subramania m et al., 2001)

\subsection{GFP as an in vivo reporter for protein localization}

The green fluorescent protein (GFP) of the Pacific jellyfish Aequorea victoria was discovered in the early $60^{\text {th }}$ (Shimomura et al., 1962) and some of its properties were described later (Prendergast and Mann, 1978; Shimomura, 1979) but it stayed in relative obscurity for the next 3 decades. The crucial breakthroughs came with the cloning of its cDNA (Prasher et al., 1992) and the demonstration that a functional chromophore of GFP is formed when its cDNA is expressed in prokaryotic and eukaryotic heterologous systems (Chalfie et al., 1994). Since then GFP has been successfully expressed in bacteria (Chalfie et al., 1994), yeast (Kahana et al., 1995), slime mold (Moores et al., 1996), Drosophila (Wang and Hazelrigg, 1994), zebrafish (Amsterdam et al., 1996), mammalian cells (DeGiorgi et al., 1996), plants (Baulcombe et al., 1995; Casper and Holt, 1996; Epel et al., 1996), etc. Nowadays GFP has been widely used as an noninvasive marker for visualization in vivo of the subcellular localization of proteins, since it seems to have no localization signals (wild-type GFP is distributed throughout the nucleus and the cytoplasm, but excluded from the nucleolus and vesicles, for review see Cubit et al., 1995) and tolerates $\mathrm{N}$ or C-terminal fusions with a variety of proteins without disturbing its or their native conformations and functions.

The green fluorescent protein is a polypeptide chain of 238 amino acid residues with a calculated molecular weight of 26888 Da (Prasher et al., 1992) which folds as a barrel of $11 \mathrm{~B}$-sheets of 9-13 amino acids each, wrapped around a central a-helix (a stretch of the amino acid residues 56-72, containing the Ser65-Tyr66-Gly67 residues which form the wild-type chromophore) and short helical segments at the ends of the cylinder (Ormo et al., 1996; Yang et al., 1996). The folding and maturation of the GFP chromophore is a rather thermo-sensitive process (Lim et al., 1995) but once formed, GFP is quite resistant to heat denaturation at $90^{\circ} \mathrm{C}$ with $6 \mathrm{M}$ guanidine hydrochloride and also to denaturing $\mathrm{pH}$ ranges $(\mathrm{pH}<4.0$ or $\mathrm{pH}>12.0$ ); after reversal of the denaturing conditions (by dialysis or neutralization) nearly total renaturation occurs within minutes (Ward and Bokman, 1982). 
The wild-type GFP has a major absorption/excitation peak at $395 \mathrm{~nm}$, another minor excitation peak at $475 \mathrm{~nm}$ and an emission peak at $508 \mathrm{~nm}$ (Morise et al., 1974); the intensity ratios of the absorption peaks are typically $4: 1 \mathrm{but} \mathrm{pH}$ and salts can influence it. Analysis of a still-fluorescent hexapeptide derived by enzyme proteolysis of denatured GFP led to the proposal that the chromophore of GFP originates from an internal SerTyr-Gly sequence which is post-translationally modified into a 4-(phydroxybenzylidene)-imidazolidin-5-one structure attached to the peptide backbone through the 1 and 2 positions of the ring (Shimomura, 1979). Heim et al., 1994 have proposed a two-step scheme for the mechanism of this obviously auto-catalytic process, dependent only on molecular oxygen. After the GFP polypeptide chain has folded into a nearly native conformation, the first step is a nucleophilic attack of the amino-group of Gly67 onto the carbonyl-group of Ser65 with a subsequent elimination of a $\mathrm{H}_{2} \mathrm{O}$ molecule, which results in the formation of an imidazolidinone ring. The second (and rate-limiting) step is a dehydrogenation of the a- $\beta$ bond of the Tyr66 residue by $\mathrm{O}_{2}$ with the release of $\mathrm{H}_{2} \mathrm{O}_{2}$; this puts the Tyr66 aromatic group into conjugation with the imidazolidinone p-structure and only at this step the chromophore acquires absorbance and fluorescence properties. In the mature state of GFP the chromophore becomes quite inaccessible, buried almost in the geometrical center of the " $\beta$-can" (Remington, 2000) and is surrounded by both non-polar and polar amino acid residues which influence its absorption and emission properties (Yang et al, 1996, Remington, 2000).

Surprisingly, amino acid substitutions in the chromophore (besides Gly67) and in the whole GFP are quite tolerated (in contrast to deletions !) and as long as the GFP cDNA is available since 1992, a lot of GFP variants with amino acid exchanges have been created by random or directed mutagenesis in order to improve the GFP spectra, to optimize the codon usage, to reduce the thermosensitivity, to facilitate the formation of the chromophore, to remove a cryptic splicing site in plants (Haseloff et al., 1997), etc. Summarizing all mutants is beyond the scope of this introduction, so only the properties of the sGFP (S65T) variant used in this work will be described in some details. This variant was with a synthetically optimized gene sequence for human-preferred codons (Haas et al., 1996) which also gave higher level of protein expression in maize leaf protoplasts (Chui et al., 1996). It also had the substitution of Ser? Thr in the chromophore (SYG? TYG, Heim et al., 1995) which results in:

$\checkmark$ a shift of the absorption maximum to $489 \mathrm{~nm}$ and of the emission to $511 \mathrm{~nm}$ (Heim et al., 1995);

$\checkmark$ an enhancement of the brightness - the extinction coefficient of the S65T mutant is $39200 \mathrm{M}^{-1} \mathrm{~cm}^{-1}$ (21000 $\mathrm{M}^{-1} \mathrm{~cm}^{-1}$ of wild type, Heim and Tsien, 1996);

$\checkmark$ approximately 4 times faster maturation of the chromophore (about $90 \mathrm{~min}$ );

$\checkmark$ improved resistance to photobleaching.

One possible explanation why the S65T substitution changes the excitation properties of GFP is that the hydroxyl group of Ser65 donates a hydrogen bond to Glu222, stabilizing its ionized form, while the hydroxyl group of Thr65 acts as a Hbond acceptor and stabilizes the non-charged form of Glu222 which favors the phenolate form of Tyr66, absorbing light at $470 \mathrm{~nm}$ (Ormo et al., 1996). 
Initial problems in expressing and visualizing GFP in plant cells have been overcome by the extensive engineering of the coding sequence and nowadays transiently or stably expressed modified variants and spectral mutants are widely used in plants as in vivo reporters for the localization of GFP-tagged proteins of interest. The GFP reporter tag can be directly imaged in living cells without lethal staining, the emission of the chromophore (which is derived by post-translational modifications from the amino acid residues of the protein itself) requires only blue or UV light and oxygen but no exogenous substrate (compared to other reporters like B-glucoronidase (GUS), luciferase (LUC), etc.); in most cases the GFP tag does not disturb the native conformation, functions and targeting of the protein it is fused to or the development of the cells in general. A relative disadvantage is the high level of GFP protein expression necessary to detect the GFP fluorescence and to distinguish it from the strong auto-fluorescence of plant cellular organelles (e.g. chloroplasts) and some phenol compounds present in the cytosol and the cell walls; for some studies a problem might also be the slow maturation and the slow turnover of GFP.

One of the many possibilities arising from the expression of fluorescent GFP-tagged proteins is to characterize their dynamics in the compartments of living cells by recording the fluorescent signals in a small volume over a period of time and to draw conclusions about the mobility properties of the fluorescent particles from the fluctuations of the signals. Such a experimental approach known as "Fluorescence correlation spectroscopy" (FCS) was developed in the early seventies (Madge et al., 1972; Elson and Madge, 1974). FCS is a very sensitive biophysical method for high-resolution analysis of spontaneous fluorescence fluctuations during measurement time intervals, caused by diffusion of the fluorescent species through the detection volume. When combined with the advantages of modern confocal laser-scanning microscopy (CLSM) it can be applied for in vivo measurements of the molecular dynamics of fluorescently-labeled molecules for the determination of the local concentrations, diffusion coefficients, flow rates, formation of aggregates, etc. The mathematical analysis of the fluctuations i.e. the "autocorrelation function" (ACF) extracts the information about all these parameters from the recorded fluorescent trace. The normalized ACF is defined as:

$$
G(t)=\{d F(t) \cdot d F(t+t)\} /\{F(t)\}^{2}
$$

where $d F(t)=F(t)-\{F(t)\}$ are the fluorescence deviations from the mean value $\{F(t)\}$ and $t$ is the lag time. From the ACF the self-similarity of the fluctuating signal can be estimated; for small $t$ the signal is self-similar since photons emitted from the same molecules during their transition through the focus are being correlated; for larger $t$ the signal is not self-similar anymore since the molecules have time to leave the detection focus. The amplitude of ACF is reciprocal to the average number of molecules in the detection focus; the decay time $t_{\text {diff }}$ (approx. the time when ACF has decayed to half of its amplitude) represents the time it takes for the molecules to pass through the focus and having once calibrated the detection volume the diffusion coefficients can be calculated. When there are multiple fluorescent species in the sample and/or anomalous diffusion of the particles e.g. in membranes (Schwille et al., 1999) or in nuclei (Wachsmuth et al., 2000), the FCS curves become more difficult to interpret, still with appropriate modifications of the ACF the parameters of the particles can be determined. 


\subsection{Aims of the project}

More information about the coordinate regulation of the genes involved in plant defense response against pathogen attacks is still necessary in order to understand better these defense reactions. One of the major signaling molecules taking part in the defense pathway signaling is salicylic acid (SA). The SA-responsive as-1-like cis-elements present in the promoters of many pathogen-induced defense genes are the binding targets for the family of the TGA bZIP plant transcription factors, whose properties seem to be modulated reversibly by regulation of their DNA-binding affinity and activation potentials as well as by regulation of their localization in the cellular compartments.

The aims of the project were to study in vivo the subcellular localization and the mobility properties of the TGA factors before and during the activation of the transcription of defense response genes. For this purpose fusion proteins between the full-length TGA2.1, TGA2.2 and TGA1a factors from Nicotiana tabacum or their separate N- or C-terminal domains and the green fluorescent protein (GFP) from Aequorea victoria were to be created and expressed transiently in tobacco protoplasts or constitutively in transgenic tobacco plants during the course of this work.

In order to confirm that the constructed TGA-GFP fusions are functionally active proteins the DNA-binding activity of those fusions to the as- 1 -element and their influe nce on the SA- or 2,4-D- inducible GST gene expression were to be investigated in leaves of the transgenic plants by gel retardation assays (EMSAs) and Northern blotting respectively.

The localizations of the fusion proteins in the subcellular compartments before or after stimulation were to be visualized by fluorescent microscopy or by confocal laserscanning microscopy (CLSM). The results about the localization of the fusion proteins from the fluorescent microscopical studies were to be compared with the data obtained from biochemical studies with nuclear and cytosolic protein extracts from transgenic tobacco leaves, tested with a polyc lonal antiserum with an affinity directed against the Ctermini of TGA2.1 and TGA2.2, which was to be generated in the course of this work.

The mobility parameters (diffusion rate of the molecules, mobility fractions ratios, etc.) of the TGA-GFP fusion proteins, which might give more detailed information about the involvement of the TGA-GFP fusions in some kind of interactions with DNA or other proteins were to be determined in nuclei under non-induced or induced conditions using the fluorescence correlation spectroscopy (FCS) technique combined with CLSM. 


\section{Materials}

\subsection{Devices}

Device
Autoclave
Automatic pipettes
Cold chamber $\left(4^{\circ} \mathrm{C}\right)$
Confocal laser-scanning microscope
Cooling centrifuge
Counting chamber
Electroporator
Fluorescent microscope
Fluorescence Correlation Spectroscopy
(FCS) station
Gel documentation station
Gel electrophoresis chambers, horizontal
Gel electrophoresis chambers, vertical

Handheld radiation monitor

Heating blocks

Heating shaker

Heating stirrer

Hybridization ovens

Hybridization shaking water bath

Incubation chambers

PCR thermocyclers

Peristaltic pump

$\mathrm{pH}$-meter

Phosphoimager

Photometer

Plant growth chambers

Power supplies

RNA-/DNA-calculator

Shaker

Scales

Scanner

Sequencing station

Spectrophotometer for microtiter plate

Model
3870 ELV
LSM 510
Sorvall RC 5B Plus
Fuchs-Rosenthal
GenePulser II
Axiovert 35
ConfoCor 2 /
LSM 510

Joey \#JGC4

V 15-17

Contamat

HB-130

Thermo mixer 5436

RCT basic

The Belly Dancer®

ProGene

MiniCycler PTC-150

Cyclo1

HI 9321

BAS- 1000

Unikon 720 LC

I-37L4VL

E 323, E 835

PS 305

EC 105, EC 250-90

GeneQuant II

ST 5

A $120 \mathrm{~S}$

Spo 51, Sac 62

ScanJet 4c

ABI PRISM ${ }^{\mathrm{TM}} 310$

MRX Plate Reader

\section{Manufacturer}

Tuttnauer

Gilson

ILKA Zell

Zeiss

DuPont

Brand

BioRad

Zeiss

Zeiss

MWG Biotech

Institute's workshop

AGS

Gibco BRL

Institute's workshop

Eberline

Unitek

Eppendorf

IKA Labortechnik

Bachhofer

Stovall

WTC binder

Memmert

Techne

MJ Research

Roth

Hanna Instruments

Fuji

Kontron

Weiss Technik

Percival Scientific

Consort

Gibco BRL

E-C Apparatus Corp.

Pharmacia

M. Zipperer GmbH

Sartorius Analytic

ScalTec

Hewlett Packard

Perkin Elmer

Dynex 
Sterile benches

Table-top centrifuges

Table-top cooling centrifuges

Ultra-centrifuge

Ultra-low freezers $\left(-80^{\circ} \mathrm{C}\right)$

Ultra-sound sonicator

UV-transilluminator

Vacuum evaporator

Vacuum gel dryer

Water deionization system
Microflow Laminar

Biofuge Pico

5403, 5415R

Centricon T-1065

C54285

SoniPrep 150

FLX $20 \mathrm{M}$

SpeedVac L 05

Phero-Temp

Option 4, Maxima
Nunc

Heraeus

Eppendorf

Kontron

New Brusnwick

Scientific

Scientific Instr.

Vilber Lourmat

WKF

Biotec-Fischer

ELGA

\subsection{Chemicals}

\section{Substance}

$30 \%(\mathrm{w} / \mathrm{v})$ acrylamide: N,N-methylene-bisacrylamide (37.5 : 1)

$40 \%$ (w/v) acrylamide: N,N-methylene-bisacrylamide (19:1)

$\left[\mathrm{a}-{ }^{32} \mathrm{P}\right]-d A T P(800 \mathrm{Ci} / \mathrm{mmol})$

Agarose SeaKem LE

Ammonium persulfate (APS)

Ampicillin (Amp)

Antipain

Aprotinin

Bestatin

Bovine serum albumin (BSA)

Bradford reagent

Bromphenolblue

Cefotaxim

Chloroform

Chymostatin

Coomassie Brilliant Blue R-250

4,6-diamidino-2-phenylindole (DAPI)

2,4-dichlorophenylacetic acid (2,4-D)

Diethylpirocarbonate (DEPC)

N,N-dimethylformamide (DMF)

Dimethylsulfoxide (DMSO)

Dithiothreitol (DTT)

dNTPs

Ethanol

Ethylenediaminotetraacetate (EDTA)

Ethidium bromide (EtBr)

Formaldehyde (37\%)

Glacial acetic acid

Glutathione

Glutathione Sepharose 4B

\section{Manufacturer}

Roth

Roth

Hartmann Analytic

Biozym

Biometra

AGS

Serva, AppliChem

Biomol

AppliChem

Serva

Roth

Roth

Duchefa

Merck

Sigma

Merck

Roth

Sigma

Roth

J.T. Baker Chemicals

Sigma

Sigma

MBI, Roth

Merck

AppliChem

Roth

Roth

Merck

Sigma

Pharmacia 
Glycerol

Glycine

Hepes

Hexyleneglycol (2-methyl-2,4-pentadiol)

Isoamyl alcohol

Isopropanol

Isopropylthiogalactoside (IPTG)

Kanamycin (Kan)

Leptomycin B (LMB)

Leupeptin

B-mercaptoethanol ( $\beta$-ME)

2-[N-morpholino]-ethanesulfonic acid (MES)

3-[N-morpholino]-propanesulfonic acid (MOPS)

Murashige and Skoog medium (MS)

Non-fat dried milk SUCOFIN®

Nonidet P40

Orange $\mathrm{G}$

Pefabloc SC (= AEBSF)

Pepstatin A

1,10-phenanthroline

Phenol

Phenylmethanesulfonyl fluoride (PMSF)

Polydesoxyinosin-desoxycitidine (poly dI/dC)

Polyethyle neglycol (PEG) diverse

Polyvinylpolypyrrolidone (PVP) - 40

Ponceau S

Salicylic acid (SA)

Select Agar

Spermidine

Spermine

TAPS

TEMED

Tris(hydroxymethyl)aminomethane (Tris)

Triton X-100

Tween ${ }^{\circledR} 20$

Urea

$\mathrm{X}-\mathrm{Gal}$

X-ray film developer LX24

$\mathrm{X}$-ray film fixator AL4

Xylenecyanol FF
Roth, Merck

Roth

Roth

Aldrich

Roth

Roth

BioTech Grade

Sigma

Sigma

Serva

Roth

Sigma

Roth

Duchefa

TSI

Fluka

Sigma

Roche Diagnostics

Sigma

Roth

AppliChem

Fluka

Sigma

Roth, Sigma

Sigma

Sigma

Merck

Life Technologies

Sigma

Sigma

ICN Biochemicals Inc.

Roth

Roth

Roth

Sigma

Roth

BioTech Grade

Kodak

Kodak

Roth

Standard chemicals not mertioned above were obtained from Boehringer, Fluka, Merck, Serva, Sigma, Roth, etc. 


\subsection{Consumables}

\section{Product}

3MM paper

Centricon® ${ }^{\circledR}$ YM-30 centrifugal filter devices

Dialysis tubes VISKING type 8

Electroporation cuvettes

Empty plastic columns for affinity chromatography resins

Glasses for sterile plant cultures

Leukopor® tape

Microscopic slides

MicroSpin G25 size-exclusion columns

Miracloth

Nylon membranes Hybond-N+

PDVF membranes Immobilon ${ }^{\mathrm{TM}} \mathrm{P}$

Single-use plastic ware

X-ray films Cronex 10T, Cronex 4
Manufacturer

Whatman

Millipore

Biomol

BioRad

BioRad

Weck

Beiersdorf

Roth

Pharmacia

Calbiochem

Amersham Pharmacia

Millipore

Sarstedt, Eppendorf, Greiner, Biozym, Roth DuPont

2.4. Buffers, solutions, media and additives

\subsubsection{Buffers}

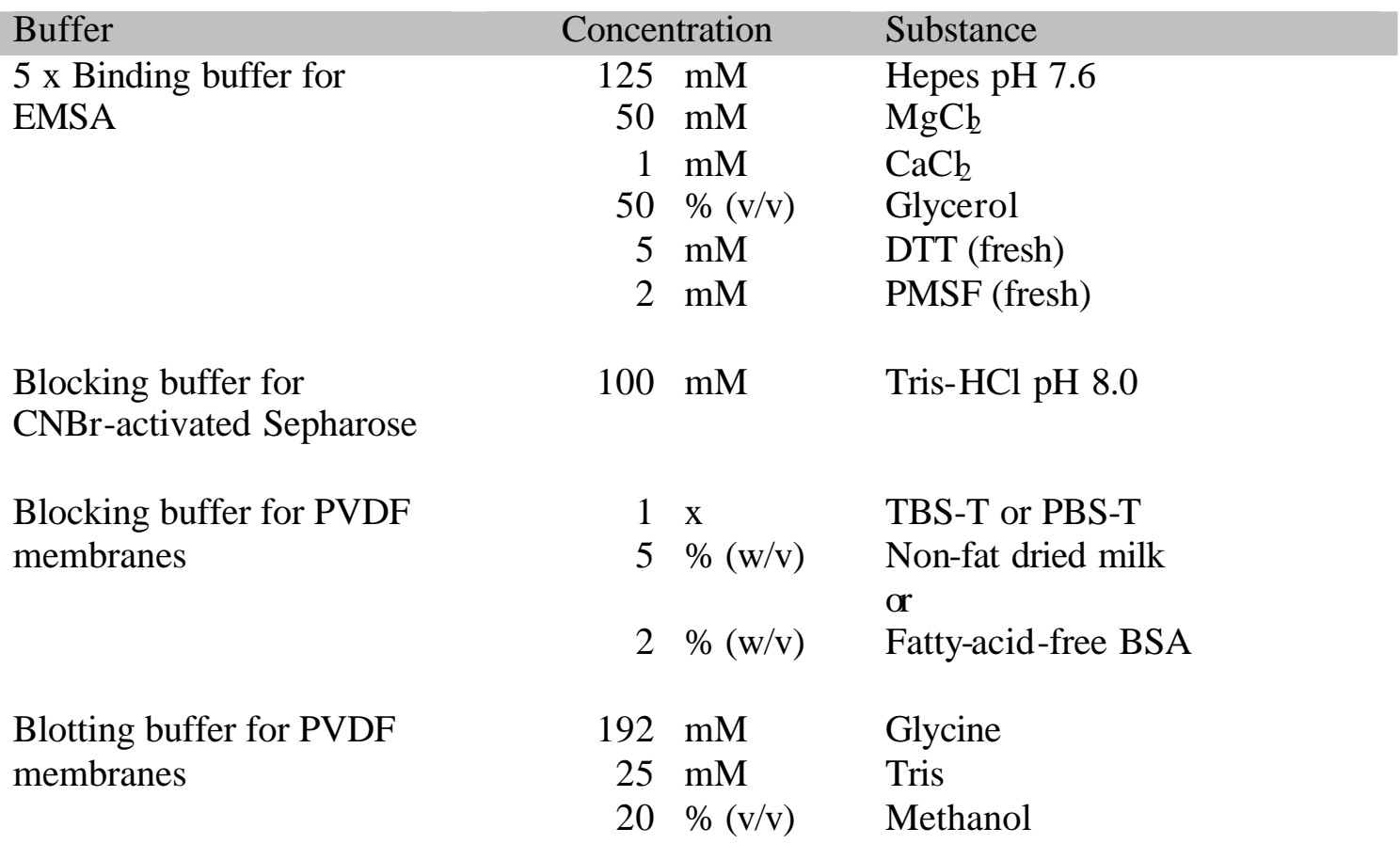


Buffer 1 A

Buffer 0.5 A

Buffer C

Church hybridization

solution

Coomassie fixing solution

Coomassie staining solution

Coomassie washing solution

Coupling buffer for

$\mathrm{CNBr}$-activated Sepharose
$1 \mathrm{M}$

$250 \mathrm{mM}$

$20 \mathrm{mM}$

$10 \mathrm{mM}$

$0.15 \mathrm{mM}$

$0.5 \mathrm{mM}$

$0.6 \%(\mathrm{v} / \mathrm{v})$

$80 \mathrm{mM}$

$0.5 \mathrm{M}$

$250 \mathrm{mM}$

$20 \mathrm{mM}$

$10 \mathrm{mM}$

$0.15 \mathrm{mM}$

$0.5 \mathrm{mM}$

$0.6 \%(\mathrm{v} / \mathrm{v})$

$80 \mathrm{mM}$

$100 \mathrm{mM}$

$50 \mathrm{mM}$

$10 \mathrm{mM}$

$5 \mathrm{mM}$

$20 \mathrm{mM}$

$0.2 \mathrm{mM}$

$50 \mu \mathrm{g} / 1$

$50 \mu \mathrm{g} / 1$

$50 \mu \mathrm{g} / 1$

$50 \mu \mathrm{g} / 1$

$50 \mu \mathrm{g} / 1$

$250 \mathrm{mM}$

$1 \mathrm{mM}$

$7 \%(\mathrm{w} / \mathrm{v})$

$25 \%(\mathrm{v} / \mathrm{v})$

$10 \%(\mathrm{v} / \mathrm{v})$

$0.01 \%(\mathrm{w} / \mathrm{v})$

$10 \%(\mathrm{v} / \mathrm{v})$

$10 \%(\mathrm{v} / \mathrm{v})$

$100 \mathrm{mM}$

$500 \mathrm{mM}$
Hexylenglycol

Sucrose

TAPS pH $8.5\left(25^{\circ} \mathrm{C}\right)$

$\mathrm{MgCl} 2$

Spermin

Spermidin

Nonidet P-40

B-mercaptoethanol (fresh)

Hexylenglycol

Sucrose

TAPS pH $8.5\left(25^{\circ} \mathrm{C}\right)$

$\mathrm{MgCh}$

Spermin

Spermidin

Nonidet P-40

B-mercaptoethanol (fresh)

Sodium phosphate $\mathrm{pH} 7.8$

$\mathrm{NaCl}$

$\mathrm{MgCh}$

EDTA

ß-mercaptoethanol (fresh)

PMSF (fresh)

Antipain

Aprotinin

Chymostatin

Leupeptin

Pepstatin

Sodium phosphate $\mathrm{pH} 7.2$

EDTA pH 8.0

SDS

Isopropanol

Glacial acetic acid

Coomassie Brilliant Blue G-250

Glacial acetic acid

Glacial acetic acid

$\mathrm{NaHCO}_{3}$ pH 8.3

$\mathrm{NaCl}$ 
$10 \mathrm{x}$ digestion mix for mesophyl protoplast preparations

$10 \times$ DNA ligation buffer

$10 \times$ DNA loading buffer

Dialysis buffer

Electroporation buffer for mesophyll protoplasts

Elution buffer for antibodies

Extraction buffer for total protein
$10 \mathrm{x}$

TEX buffer $\mathrm{pH} 5.7$

$4 \%(\mathrm{w} / \mathrm{v})$

Cellulase R10

$2 \%(\mathrm{w} / \mathrm{v})$

Macerozyme R10

mix for $30 \mathrm{~min}$

$3000 \mathrm{x}$ g for $5 \mathrm{~min}$

filter-sterilize

store $5 \mathrm{ml}$ aliquots at $-80^{\circ} \mathrm{C}$

$400 \mathrm{mM}$

$100 \mathrm{mM}$

$100 \mathrm{mM}$

$5 \mathrm{mM}$

Tris- $\mathrm{HCl} \mathrm{pH} 7.8$ at $25^{\circ} \mathrm{C}$

$\mathrm{MgCh}$

DTT

ATP

$67 \%(w / v) \quad$ Sucrose

$50 \mathrm{mM}$

EDTA pH 8.0

$0.42 \%(\mathrm{w} / \mathrm{v})$

Bromphenolblue

$0.42 \%(\mathrm{w} / \mathrm{v})$

Xylenecyanol

$0.42 \%(\mathrm{w} / \mathrm{v})$

Orange $\mathrm{G}$

$\begin{array}{rl}100 & \mathrm{mM} \\ 20 & \mathrm{mM} \\ 10 & \%(\mathrm{v} / \mathrm{v}) \\ 0.2 & \mathrm{mM} \\ 0.5 & \mathrm{mM} \\ 0.2 & \mathrm{mM} \\ & \\ 50 & \mu \mathrm{g} / \mathrm{l} \\ 50 & \mu \mathrm{g} / \mathrm{l} \\ 50 & \mu \mathrm{g} / 1 \\ 50 & \mu \mathrm{g} / 1 \\ 50 & \mu \mathrm{g} / \mathrm{l}\end{array}$

$\mathrm{KCl}$

Hepes pH 7.5

Glycerol

EDTA

DTT (fresh)

PMSF (fresh)

$\begin{array}{rl}0.4 & \mathrm{M} \\ 2.4 & \mathrm{~g} / 1 \\ 6 & \mathrm{~g} / 1 \\ 600 & \mathrm{mg} / 1\end{array}$

Antipain

Aprotinin

Chymostatin

Leupeptin

Pepstatin

Sucrose $(13.7 \%)$

Hepes

$\mathrm{KCl}$

$\mathrm{CaCl}_{2}$

pH $7.2(\mathrm{KOH})$

filter-sterilize

$100 \mathrm{mM}$

Glycine- $\mathrm{HCl}$ pH 2.5

$4 \mathrm{M}$

Urea

$16.6 \%(\mathrm{v} / \mathrm{v}) \quad$ Glycerol

$5 \%(\mathrm{v} / \mathrm{v}) \quad$ B-mercaptoethanol (fresh)

$5 \%(\mathrm{w} / \mathrm{v}) \quad$ SDS

$0.5 \%(\mathrm{w} / \mathrm{v}) \quad$ Bromphenolblue 
FixProt extraction buffer

$10 \times$ KGB buffer

10 x Klenow buffer

Loading buffer for EMSA

Loading buffer for proteins

Lysis buffer for bacteria

$1 \mathrm{x}$ Lysis buffer for nuclei

$\begin{array}{rll}50 & \mathrm{mM} & \text { Hepes }\left(\mathrm{pH} 7.5 \text { at } 25^{\circ} \mathrm{C} \text { ) }\right. \\ 20 & \mathrm{mM} & \mathrm{KCl} \\ 2.5 & \mathrm{mM} & \text { DTT (fresh) } \\ & & \\ 50 & \mu \mathrm{g} / \mathrm{ml} & \text { Antipain } \\ 2 & \mu \mathrm{g} / \mathrm{ml} & \text { Aprotinin } \\ 20 & \mu \mathrm{g} / \mathrm{ml} & \text { Chymostatin } \\ 5 & \mu \mathrm{g} / \mathrm{ml} & \text { E-64 } \\ 5 & \mathrm{mM} & \text { EGTA } \\ 1 & \mu \mathrm{g} / \mathrm{ml} & \text { Leupeptin } \\ 1 & \mathrm{mg} / \mathrm{ml} & \text { Pefabloc SC } \\ 1 & \mu \mathrm{g} / \mathrm{ml} & \text { Pepstatin A } \\ 10 & \mathrm{mM} & \text { 1,10-phenanthroline }\end{array}$

$1 \mathrm{M} \quad$ Potassium glutamate

$250 \mathrm{mM} \quad$ Tris-Acetate $\mathrm{pH} 7.5$

$100 \mathrm{mM} \quad$ Magnesium acetate

$5 \mathrm{mM} \quad$ B-mercaptoethanol or DTT

$0.5 \mathrm{mg} / \mathrm{ml} \quad$ BSA

$\begin{array}{rll}500 & \mathrm{mM} & \text { Tris- } \mathrm{HCl} \mathrm{pH} 8.0 \text { at } 25^{\circ} \mathrm{C} \\ 50 & \mathrm{mM} & \mathrm{MgCh} \\ 10 & \mathrm{mM} & \text { DTT }\end{array}$

$42 \%(\mathrm{v} / \mathrm{v}) \quad 5 \mathrm{x}$ Binding buffer

$58 \%(\mathrm{v} / \mathrm{v}) \quad$ Glycerol

$\begin{array}{rll}100 & \mathrm{mM} & \text { Tris } \\ 7.5 & \%(\mathrm{v} / \mathrm{v}) & \text { Glycerol } \\ 3 & \%(\mathrm{w} / \mathrm{v}) & \text { SDS } \\ 0.05 & \%(\mathrm{w} / \mathrm{v}) & \text { Bromphenolblue } \\ 5 & \%(\mathrm{v} / \mathrm{v}) & \text { B-mercaptoethanol (fresh) }\end{array}$

$10 \mathrm{mM} \quad$ Tris- $\mathrm{HCl} \mathrm{pH} 8.0$

$1 \mathrm{mM} \quad$ EDTA

$15 \%(\mathrm{w} / \mathrm{v}) \quad$ Sucrose

$2 \mathrm{mg} / \mathrm{ml} \quad$ Lysozyme

$0.2 \mathrm{mg} / \mathrm{ml} \quad$ RNaseA

$0.2 \mathrm{mg} / \mathrm{ml} \quad$ BSA

$\begin{array}{rll}110 & \mathrm{mM} & \mathrm{KCl} \\ 15 & \mathrm{mM} & \text { Hepes } \mathrm{pH} 7.6 \\ 5 & \mathrm{mM} & \mathrm{MgCl} \\ 5 & \mathrm{mM} & \text { DTT }\end{array}$

Protease inhibitors: 


\begin{tabular}{|c|c|c|c|}
\hline & 1 & $\mathrm{mM}$ & EGTA \\
\hline & 1 & $\mathrm{mM}$ & 1,10-phenanthroline \\
\hline & 50 & $\mu \mathrm{g} / \mathrm{l}$ & Antipain \\
\hline & 2 & $\mu \mathrm{g} / 1$ & Aprotinin \\
\hline & 10 & $\mu \mathrm{g} / \mathrm{l}$ & Chymostatin \\
\hline & 5 & $\mu \mathrm{g} / 1$ & E-64 \\
\hline & 1 & $\mu \mathrm{g} / 1$ & Leupeptin \\
\hline & 1 & $\mathrm{mg} / \mathrm{l}$ & Pefabloc SC \\
\hline MMM solution for BY-2 & 0.5 & $\mathrm{mM}$ & Manitol \\
\hline protoplast preparations & 0.1 & $\%(\mathrm{w} / \mathrm{v})$ & MES \\
\hline & 15 & M & $\mathrm{MgCh}$ \\
\hline & & & $\mathrm{pH} 5.8$ \\
\hline & & & autoclave \\
\hline & & & store at root temperature \\
\hline $10 \times \mathrm{MEN}$ & 200 & $\mathrm{mM}$ & MOPS \\
\hline & 10 & $\mathrm{mM}$ & EDTA \\
\hline & 50 & $\mathrm{mM}$ & Sodium acetate \\
\hline & & & $\mathrm{pH} 7.0(\mathrm{NaOH})$ \\
\hline MS for BY-2 protoplast & 1 & $\mathrm{x}$ & MS salts \\
\hline preparations & 100 & $\mathrm{mg} / \mathrm{l}$ & Myo-inositol \\
\hline & 1 & $\mathrm{mg} / \mathrm{l}$ & Thiamine \\
\hline & 0.2 & $\mathrm{mg} / \mathrm{l}$ & $2,4-\mathrm{D}$ \\
\hline & 255 & $\mathrm{mg} / \mathrm{l}$ & KH2PO4 \\
\hline & 30 & $\mathrm{~g} / \mathrm{l}$ & Sucrose \\
\hline & & & pH $5.0(\mathrm{KOH})$ \\
\hline & & & autoclave \\
\hline & & & store at room temperature \\
\hline $1 \times$ PBS buffer & 68 & $\mathrm{mM}$ & $\mathrm{NaCl}$ \\
\hline & 58 & $\mathrm{mM}$ & $\mathrm{Na}_{2} \mathrm{HPO}_{4}$ \\
\hline & 17 & $\mathrm{mM}$ & $\mathrm{NaH}_{2} \mathrm{PO}_{4}$ \\
\hline & & & $\mathrm{pH} 7.4(\mathrm{NaOH})$ \\
\hline $1 \times$ PBS- $T$ & 1 & $\mathrm{x}$ & PBS \\
\hline & 0.1 & $\%(\mathrm{v} / \mathrm{v})$ & Tween 20 \\
\hline PCI mix & 25 & vol & Phenol \\
\hline & 24 & vol & Chloroform \\
\hline & 1 & vol & Isoamylalcohol \\
\hline
\end{tabular}


$10 \times$ PCR HiFi buffer

PEG solution for BY-2 protoplast preparations

Ponceau staining solution

Rapid Mini I

Rapid Mini II

Rapid Mini III

3 x RNA loading buffer

RNase-free $\mathrm{H}_{2} \mathrm{O}$

$1 \times$ RPB buffer

$\begin{array}{rll}500 & \mathrm{mM} & \mathrm{KCl} \\ 100 & \mathrm{mM} & \text { Tris- } \mathrm{HCl} \mathrm{pH} 8.4 \\ 8 & \mathrm{mM} & \mathrm{MgCh} \\ 1 & \%(\mathrm{w} / \mathrm{v}) & \text { Triton X-100 } \\ 0.1 & \%(\mathrm{w} / \mathrm{v}) & \text { Gelatin }\end{array}$

$40 \%(\mathrm{v} / \mathrm{v}) \quad$ PEG-4000

$0.4 \mathrm{M} \quad$ Manitol

$0.1 \mathrm{M} \quad \mathrm{Ca}\left(\mathrm{NO}_{3}\right)_{2}$

$\mathrm{pH} 8.0$ - $9.0(\mathrm{KOH})$

autoclave

pH stabilizes at $5.0-6.0$

store at $-20^{\circ} \mathrm{C}$

$0.1 \%(\mathrm{w} / \mathrm{v}) \quad$ Ponceau S

$5 \%(\mathrm{v} / \mathrm{v}) \quad$ Glacial acetic acid

$\begin{array}{lll}25 & \mathrm{mM} & \text { Tris- } \mathrm{HCl} \mathrm{pH} 8.0 \\ 10 & \mathrm{mM} & \text { EDTA } \\ 50 & \mathrm{mM} & \text { Glucose }\end{array}$

$\begin{array}{rll}200 & \mathrm{mM} & \mathrm{NaOH} \\ 1 & \%(\mathrm{w} / \mathrm{v}) & \mathrm{SDS}\end{array}$

3 M Potassium acetate

$50 \mathrm{ml} / \mathrm{l} \quad \mathrm{HCOOH}$

$42.9 \%(\mathrm{v} / \mathrm{v}) \quad$ Formamide (deionized)

$33.3 \%(\mathrm{v} / \mathrm{v}) \quad 10 \times \mathrm{MOPS}$

$12 \%(\mathrm{v} / \mathrm{v}) \quad$ Glycerol

$3.7 \%(\mathrm{v} / \mathrm{v}) \quad$ Formaldehyde

$4 \mathrm{mM}$ EDTA

$0.025 \%(\mathrm{w} / \mathrm{v}) \quad$ Bromphenolblue

$0.025 \%(\mathrm{w} / \mathrm{v}) \quad$ Xylenecyanol

$\mathrm{H}_{2} \mathrm{O}$ incubated overnight with

$0.1 \%$ DEPC and autoclaved

$\begin{array}{rll}100 & \mathrm{mM} & \text { Tris-HCl pH } 6.8 \\ 200 & \mathrm{mM} & \text { DTT } \\ 20 & \%(\mathrm{v} / \mathrm{v}) & \text { Glycerol } \\ 4 & \%(\mathrm{w} / \mathrm{v}) & \text { SDS } \\ 0.2 & \%(\mathrm{w} / \mathrm{v}) & \text { Bromphenolblue }\end{array}$




\begin{tabular}{|c|c|c|c|}
\hline $\begin{array}{l}10 \times \text { SDS-PAGE } \\
\text { running buffer }\end{array}$ & $\begin{array}{r}25 \\
200 \\
0.1\end{array}$ & $\begin{array}{l}\mathrm{mM} \\
\mathrm{mM} \\
\%(\mathrm{w} / \mathrm{v})\end{array}$ & $\begin{array}{l}\text { Tris-HCl pH } 8.3 \\
\text { Glycine } \\
\text { SDS }\end{array}$ \\
\hline $20 \times \mathrm{SSC}$ & $\begin{array}{r}2 \\
0.3\end{array}$ & $\begin{array}{l}\mathrm{M} \\
\mathrm{M}\end{array}$ & $\begin{array}{l}\mathrm{NaCl} \\
\text { Sodium citrate } \\
\text { pH } 7.0(\mathrm{HCl})\end{array}$ \\
\hline $1 \times$ STE & $\begin{array}{r}10 \\
100 \\
5\end{array}$ & $\begin{array}{l}\mathrm{mM} \\
\mathrm{mM} \\
\mathrm{mM}\end{array}$ & $\begin{array}{l}\text { Tris-HCl pH } 8.1 \\
\mathrm{NaCl} \\
\text { EDTA }\end{array}$ \\
\hline $20 \times \mathrm{TAE}$ & $\begin{array}{r}800 \\
20 \\
2.3\end{array}$ & $\begin{array}{l}\mathrm{mM} \\
\mathrm{mM} \\
\%(\mathrm{v} / \mathrm{v})\end{array}$ & $\begin{array}{l}\text { Tris } \\
\text { EDTA } \\
\text { Glacial acetic acid } \\
\text { pH 7.5-7.8 }\end{array}$ \\
\hline $5 \times \mathrm{TBE}$ & $\begin{array}{r}450 \\
450 \\
1\end{array}$ & $\begin{array}{l}\mathrm{mM} \\
\mathrm{mM} \\
\mathrm{mM}\end{array}$ & $\begin{array}{l}\text { Tris } \\
\text { Boric acid } \\
\text { EDTA } \\
\text { pH } 8.0\end{array}$ \\
\hline $1 \times \mathrm{TBS}$ & $\begin{array}{r}50 \\
150\end{array}$ & $\begin{array}{l}\mathrm{mM} \\
\mathrm{mM}\end{array}$ & $\begin{array}{l}\text { Tris-HCl pH } 7.4 \\
\mathrm{NaCl}\end{array}$ \\
\hline $1 \times$ TBS-T & $\begin{array}{r}1 \\
0.1\end{array}$ & $\begin{array}{l}\mathrm{x} \\
\%(\mathrm{v} / \mathrm{v})\end{array}$ & $\begin{array}{l}\text { TBS } \\
\text { Tween } 20\end{array}$ \\
\hline $100 \times \mathrm{TE}$ & $\begin{array}{r}1 \\
0.1\end{array}$ & $\begin{array}{l}M \\
M\end{array}$ & $\begin{array}{l}\text { Tris-HCl pH } 8.0 \\
\text { EDTA }\end{array}$ \\
\hline $\begin{array}{l}\text { TEX buffer for mesophyl } \\
\text { protoplast preparations }\end{array}$ & $\begin{array}{r}3.052 \\
0.5 \\
0.75 \\
0.25 \\
137\end{array}$ & $\begin{array}{l}\mathrm{g} / 1 \\
\mathrm{~g} / 1 \\
\mathrm{~g} / 1 \\
\mathrm{~g} / 1 \\
\mathrm{~g} / 1\end{array}$ & $\begin{array}{l}\mathrm{B} 5 \text { salts } \\
\text { MES } \\
\mathrm{CaCl}_{2} \cdot 2 \mathrm{H}_{2} \mathrm{O} \\
\mathrm{NH}_{4} \mathrm{NO}_{3} \\
\text { Sucrose } \\
\text { pH } 5.7(\mathrm{KOH})\end{array}$ \\
\hline Urea buffer & $\begin{array}{r}8 \\
100 \\
10\end{array}$ & $\begin{array}{l}\mathrm{M} \\
\mathrm{mM} \\
\mathrm{mM}\end{array}$ & $\begin{array}{l}\text { Urea } \\
\mathrm{NaH}_{2} \mathrm{PO}_{4} \\
\text { Tris- } \mathrm{HCl} \text { pH } 8.0\end{array}$ \\
\hline
\end{tabular}


W5 solution for BY-2

protoplast preparations

Wall-digestion solution for

BY-2 protoplast preparation

$\begin{array}{rll}154 & \mathrm{mM} & \mathrm{NaCl} \\ 125 & \mathrm{mM} & \mathrm{CaCl}_{2} \\ 5 & \mathrm{mM} & \mathrm{KCl} \\ 5 & \mathrm{mM} & \text { Glucose }\end{array}$

pH 5.8-6.0 (KOH)

autoclave

store at room temperature

$\begin{array}{rll}10 & \mathrm{mM} & \text { Sodium acetate } \mathrm{pH} 5.8 \\ 250 & \mathrm{mM} & \text { Manitol } \\ 50 & \mathrm{mM} & \mathrm{CaCl}_{2} \\ 0.01 & \%(\mathrm{v} / \mathrm{v}) & \text { ß-mercaptoethanol } \\ 0.5 & \%(\mathrm{w} / \mathrm{v}) & \text { Bovine serum albumin }\end{array}$

$1 \%(\mathrm{w} / \mathrm{v}) \quad$ Cellulase Onozuka R10

$0.5 \%(\mathrm{w} / \mathrm{v}) \quad$ Macerozyme Onozuka R10

$0.1 \%(\mathrm{w} / \mathrm{v}) \quad$ Pectinase

2.4. 2. Protease inhibitors

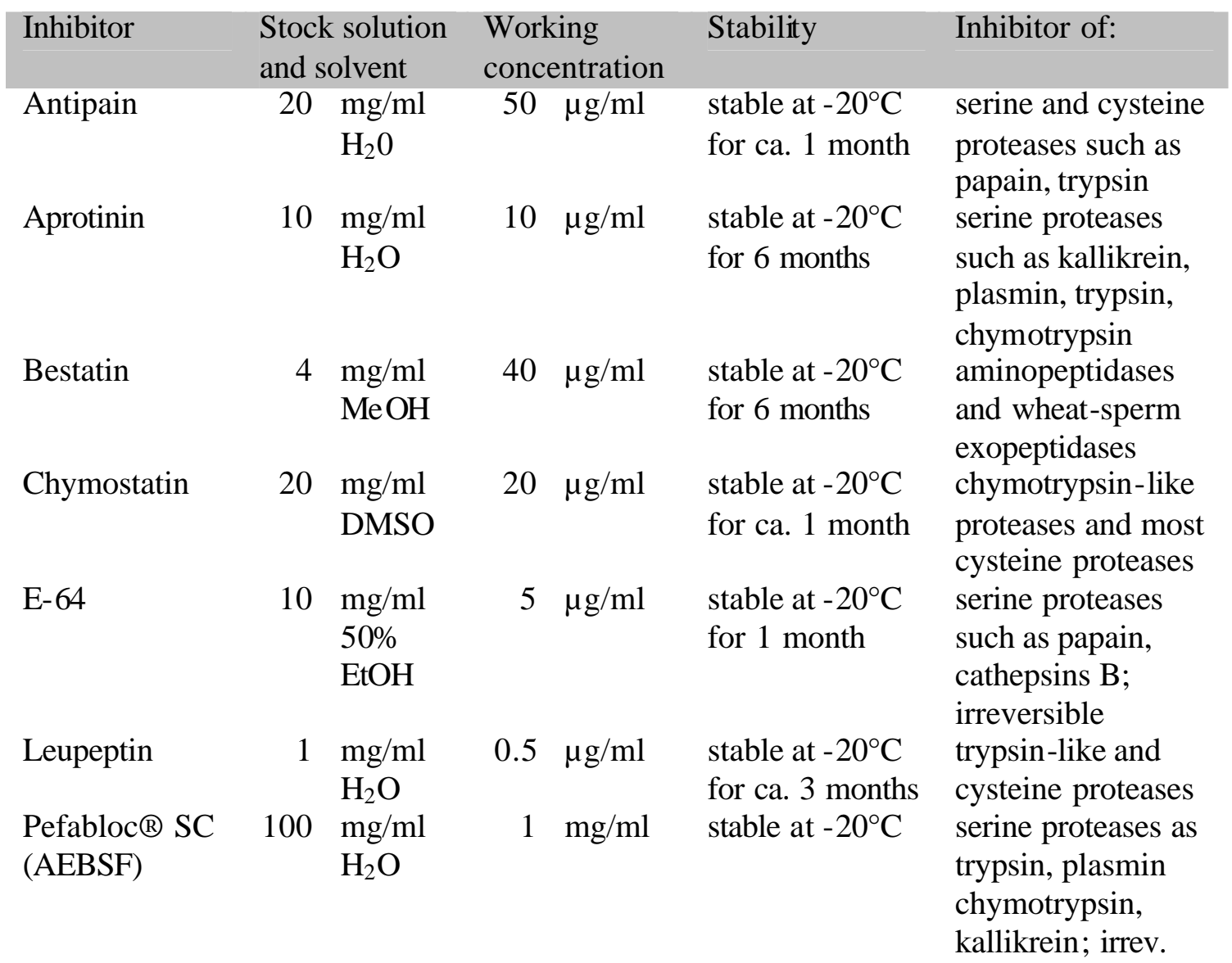




\begin{tabular}{|c|c|c|c|c|c|c|}
\hline Pepstatin A & 1 & $\begin{array}{l}\mathrm{mg} / \mathrm{ml} \\
\mathrm{DMSO}\end{array}$ & 1 & $\mu \mathrm{g} / \mathrm{ml}$ & $\begin{array}{l}\text { stable at }-20^{\circ} \mathrm{C} \\
\text { for ca. } 1 \text { month }\end{array}$ & $\begin{array}{l}\text { acid proteases such } \\
\text { as pepsin, renin, } \\
\text { cathepsin D and } \\
\text { many microbial } \\
\text { proteases }\end{array}$ \\
\hline $\begin{array}{l}1,10- \\
\text { phenanthroline }\end{array}$ & 200 & $\begin{array}{l}\mathrm{mM} \\
\mathrm{MeOH}\end{array}$ & 10 & $\mathrm{mM}$ & fresh & $\begin{array}{l}\text { metaloproteases; } \\
\text { chelates } \mathrm{Fe}^{2+}, \mathrm{Zn}^{2+} \\
\text { and other divalent } \\
\text { metals; irreversible }\end{array}$ \\
\hline EGTA & 500 & $\begin{array}{l}\mathrm{mM} \\
1 \mathrm{M} \\
\mathrm{NaOH}\end{array}$ & 5 & $\mathrm{mM}$ & stable & $\begin{array}{l}\mathrm{Ca}^{2+} \text { dependent } \\
\text { proteases }\end{array}$ \\
\hline PMSF & 200 & $\begin{array}{l}\mathrm{mM} \\
\text { i-PrOH }\end{array}$ & 200 & $\mu \mathrm{M}$ & fresh & $\begin{array}{l}\text { serine and cysteine } \\
\text { protease (trypsin, } \\
\text { chymotrypsin, etc.) }\end{array}$ \\
\hline
\end{tabular}

2.4.3. Media and additives

2.4.3.1. Media for bacteria

\begin{tabular}{|c|c|c|}
\hline Meduim & Concentration & Substance \\
\hline LB & $\begin{array}{rl}10 & \mathrm{~g} / 1 \\
5 & \mathrm{~g} / 1 \\
10 & \mathrm{~g} / 1\end{array}$ & $\begin{array}{l}\text { Tryptone } \\
\text { Yeast Extract } \\
\mathrm{NaCl} \\
\text { pH } 7.0 \text { with } \mathrm{NaOH}\end{array}$ \\
\hline $\mathrm{dYT}$ & $\begin{array}{rl}16 & \mathrm{~g} / 1 \\
10 & \mathrm{~g} / \mathrm{l} \\
5 & \mathrm{~g} / \mathrm{l}\end{array}$ & $\begin{array}{l}\text { Tryptone } \\
\text { Yeast Extract } \\
\mathrm{NaCl} \\
\text { pH } 7.0 \text { with } \mathrm{NaOH}\end{array}$ \\
\hline SOC & $\begin{array}{rl}20 & \mathrm{~g} / \mathrm{l} \\
5 & \mathrm{~g} / \mathrm{l} \\
10 & \mathrm{mM} \\
2.5 & \mathrm{mM} \\
10 & \mathrm{mM} \\
10 & \mathrm{mM} \\
20 & \mathrm{mM}\end{array}$ & $\begin{array}{l}\text { Tryptone } \\
\text { Yeast Extract } \\
\mathrm{NaCl} \\
\mathrm{KCl} \\
\mathrm{MgCl}_{2} \\
\mathrm{MgSO}_{4} \\
\text { Glucose }\end{array}$ \\
\hline YEB & $\begin{array}{rl}10 & \mathrm{~g} / 1 \\
2 & \mathrm{~g} / 1 \\
5 & \mathrm{~g} / 1 \\
5 & \mathrm{~g} / 1 \\
2 & \mathrm{mM}\end{array}$ & $\begin{array}{l}\text { Beef Extract } \\
\text { Yeast Extract } \\
\text { Peptone } \\
\text { Sucrose } \\
\mathrm{MgSO}_{4} \\
\text { pH } 7.0 \text { with } \mathrm{NaOH}\end{array}$ \\
\hline
\end{tabular}


2.4.3.2. Media for plants

\section{Medium \\ 2MS solid medium}

2MS solid medium

Callus-induction medium

$$
\begin{array}{ll}
0.5 & \mu \mathrm{g} / 1 \\
0.1 & \mu \mathrm{g} / 1
\end{array}
$$

Hydroponics medium

\begin{tabular}{rr}
\multicolumn{3}{c}{ Concentrati } \\
4.59 & $\mathrm{~g} / 1$ \\
20 & $\mathrm{~g} / 1$ \\
6.4 & $\mathrm{~g} / 1$ \\
& \\
& \\
& \\
4.59 & $\mathrm{~g} / 1$ \\
20 & $\mathrm{~g} / 1$ \\
6.4 & $\mathrm{~g} / 1$
\end{tabular}

$\begin{array}{rl}2 & \mathrm{mM} \\ 2 & \mathrm{mM} \\ 3 & \mathrm{mM} \\ 1 & \mathrm{mM} \\ 0.5 & \mathrm{mM} \\ 0.5 & \mathrm{mM}\end{array}$

$0.1 \mu \mathrm{M}$

$0.1 \mu \mathrm{M}$

$0.2 \mu \mathrm{M}$

$0.5 \mu \mathrm{M}$

$2 \mu \mathrm{M}$

Shoot-induction medium

\section{Substance}

Murashige \& Skoog medium

Glucose

Select Agar

pH 5.8 with $\mathrm{KOH}$

autoclave

Murashige \& Skoog medium

Sucrose

Select Agar

pH 5.8 with $\mathrm{KOH}$

autoclave

autoclaved 2MS solid medium

at $50^{\circ} \mathrm{C}$ add sterile:

a-naphthaleneacetic acid (NAA)

Kinetin

macroelements:

$\mathrm{Ca}\left(\mathrm{NO}_{3}\right)_{2}$

$\mathrm{MgCh}$

$\mathrm{KNO}_{3}$

$\mathrm{MgSO}_{4}$

$\mathrm{KH}_{2} \mathrm{PO}_{4}$

$\mathrm{Na}_{2}$-Fe-EDTA

microelements:

$\mathrm{Na}_{2} \mathrm{MoO}_{2}$

$\mathrm{CoSO}_{4}$

$\mathrm{CuSO}_{4}$

$\mathrm{ZnSO}_{4}$

$\mathrm{H}_{3} \mathrm{BO}_{3}$

autoclaved 2MG solid medium

at $50^{\circ} \mathrm{C}$ add sterile:

Cefotaxim a-naphthaleneacetic acid (NAA)

6-benzylaminopurine (BAP)

selective antibiotics 
2.4.4. Additives

\begin{tabular}{|c|c|c|}
\hline Substance & Working concentration & Stock solution and solvent \\
\hline Ampicillin (Amp) & $100 \mathrm{mg} / \mathrm{l}$ & $100 \mathrm{mg} / \mathrm{ml} \mathrm{H}_{2} \mathrm{O}$ \\
\hline Cefotaxim (Cefo) & $500 \mathrm{mg} / \mathrm{l}$ & $250 \mathrm{mg} / \mathrm{ml} \mathrm{H}_{2} \mathrm{O}$ \\
\hline Kanamycin (Kan) & $50 \mathrm{mg} / \mathrm{l}$ & $50 \mathrm{mg} / \mathrm{ml} \mathrm{H}_{2} \mathrm{O}$ \\
\hline Rifampicin (Rif) & $100 \mathrm{mg} / \mathrm{l}$ & $50 \mathrm{mg} / \mathrm{ml} \mathrm{MetOH}$ \\
\hline Tetracycline (Tet) & $5 \mathrm{mg} / \mathrm{l}$ & $5 \mathrm{mg} / \mathrm{ml} \mathrm{50 \%} \mathrm{EtOH}$ \\
\hline $\mathrm{X}-\mathrm{Gal}$ & $40 \mathrm{mg} / \mathrm{ml}$ & $20 \mathrm{mg} / \mathrm{ml} \mathrm{DMF}$ \\
\hline IPTG & $50 \mathrm{mg} / \mathrm{ml}$ & $23.8 \mathrm{mg} / \mathrm{ml} \mathrm{H}_{2} \mathrm{O}$ \\
\hline
\end{tabular}

2.5. Nucleic Acids

2.5.1. Oligonucleotides and DNA fragments

PCR primers and other oligonucleotides were synthesized by Roth or MWG companies.

\subsubsection{PCR primers}

The annealing temperat ures $\left(\mathrm{T}_{\mathrm{ann}}\right)$ of the PCR primers were determined according to the following equation:

$$
\mathrm{T}_{\mathrm{ann}}\left[{ }^{\circ} \mathrm{C}\right]=69.3+0.41 \times[\mathrm{GC}-\text { content }(\%)]-650 / \text { number of nucleotides }
$$

\begin{tabular}{|c|c|c|}
\hline Primer & Sequence 5'? 3' & $\mathrm{T}_{\text {ann }}\left[{ }^{\circ} \mathrm{C}\right]$ \\
\hline TGA1a-KpnI- & TAG GTA $C C$ A TGA ATT CTT CAA CGT & 57.1 \\
\hline ATG & ACA CCC AAT TTG & \\
\hline TGA1a-EcoRV- & GAT ATC TTG TTC CAG TTG AAT CAG & 51.9 \\
\hline lower-StuI & CTT C & \\
\hline TGA2.2CLeuMut & GAA TTC CGC ATA ATT GTC GAC GGT & 55.3 \\
\hline For $(E c o R I)$ & ATC TTA G & \\
\hline TGA2.2CLeuMut & GGA TCC CGG GGG CGA GCA AGC & 73.4 \\
\hline $\operatorname{Rev}($ BamHI $)$ & CAG CCA GAG CTC CCT GCT CGA AG & \\
\hline $\begin{array}{l}\text { TGA2xExpFor } \\
(\text { BamHI) }\end{array}$ & GGA $T C C$ GCA TAT GTT CAA CAG TT & 56.0 \\
\hline $\begin{array}{l}\text { TGA2xExpRev } \\
(\text { Eco RI) }\end{array}$ & GAA TTC GCA AGC CAG AGA GAG CT & 59.6 \\
\hline
\end{tabular}


2.5.1.2. Linker inserted in the pHBT-GFP plasmid

$\begin{array}{ll}\text { Oligonucleotide } & \text { Sequence 5'? 3' } \\ \text { GFP linker - for } & \text { GAT CAG GTA CCG GGC TGA TAT CGG } \\ \text { GFP linker - rev } & \text { GAT CCC GAT ATC AGC CCG GTA CCT }\end{array}$

\subsubsection{Oligonucleotides for sequencing}

\begin{tabular}{|c|c|c|}
\hline Oligonucleotide & Sequence 5'? 3' & Target \\
\hline $\begin{array}{l}\text { M13 universal } \\
\text { (22-mer) }\end{array}$ & GCC AGG GTT TTC CCA GTC ACG A & diverse cloning vectors \\
\hline $\begin{array}{l}\text { M13 reverse } \\
\text { (24-mer) }\end{array}$ & $\begin{array}{l}\text { GAG CGG ATA ACA ATT TCA CAC } \\
\text { AGG }\end{array}$ & diverse cloning vectors \\
\hline mGFP4 & GAC CAC ATG GTC CTT CTT GAG & $\begin{array}{l}\text { 3'-end of mGFP4 } \\
\text { (forward) }\end{array}$ \\
\hline pGEX 5' & GGG CTG GCA AGC CAC GTT TGG TG & $\begin{array}{l}\text { 3'-end of GST gene } \\
\text { (forward) }\end{array}$ \\
\hline $35 \mathrm{~S}$ & ATT GAT GTG ATA TCT CCA CTG AC & $\begin{array}{l}3 \text { '-end of the } 35 \mathrm{~S} \\
\text { promoter (forward) }\end{array}$ \\
\hline GFP II & TTC AGG GTC AGC TTG CCG TAG G & $\begin{array}{l}\text { middle of GFP gene } \\
\text { (reverse) }\end{array}$ \\
\hline
\end{tabular}

2.5.1.4. as -1 fragment for EMSAs

\begin{tabular}{lll} 
Fragment & Partial sequence (the $a s-1$ element only) & Preparation \\
\hline as-1-short & ...... TGACGTAAgggaTGACGCAC....... & A Bpil fragment from \\
& ...... ACTGCATT cect ACTGCGTG....... & pUC18 as -1 Bpil
\end{tabular}

2.5.1.5. Hybridization probes

\begin{tabular}{|c|c|c|}
\hline Probe & Description & Reference \\
\hline Nt103 & $\begin{array}{l}1 \mathrm{~kb} \text { EcoRI fragment from } \mathrm{pCNT} 103= \\
\text { the cDNA sequence of the } 103 \text { gene from } N \text {. } \\
\text { tabacum }\end{array}$ & $\begin{array}{l}\text { Van der Zaal et al., } \\
1991\end{array}$ \\
\hline$G F P$ & $\begin{array}{l}0.6 \mathrm{~kb} \mathrm{NcoI} / B p u 10 \mathrm{I} \text { fragment from } \mathrm{pHBT}- \\
\mathrm{L}-\mathrm{GFP}=\mathrm{a} \text { fragment of GFP }(\mathrm{S} 65 \mathrm{~T})\end{array}$ & Heim \& Tsien, 1995 \\
\hline
\end{tabular}




\subsubsection{DNA standards}

The size of DNA fragments were estimated in agarose gels in comparison to ladders of DNA fragments with known lengths:

\section{? EcoRI HindIII (own preparation)}

$24756-5148-4973-4268-2027-1904-1709-1375-947-831-564$ bp.

\section{? Pst I (own preparation)}

$14057-11497-5077-4749-4507-2838-2459-2443-2140-1986-1700-1159$

$-1093-805-514-468-448$ bp.

\section{pUC19 Hpa II (own preparation)}

$501-489-404-331-242-190-147-111-110-67$ bp.

\section{Kb Ladder (Gibco BRL)}

$12216-11198-10180-9162-8144-7126-6108-5090-4072-3054-2036-$ $1636-1018-517-506-396-344-298-220-201-154-134-75$ bp.

\subsubsection{Plasmids}

\begin{tabular}{|c|c|c|}
\hline Plasmid & Description & Reference/Genbank \\
\hline pAVA393 & $\begin{array}{l}\text { pAVA319 AF078810 derivative; Amp } \\
\text { contains the coding sequence of mGFP5 } \\
\text { under the control of the } 35 \mathrm{~S} \text { promoter; a } \\
\text { vector for transient expression in plants }\end{array}$ & $\begin{array}{l}\text { Siemering et al., } \\
\text { 1996; a gift from } \\
\text { Dr. A von Arnim }\end{array}$ \\
\hline pBin19 & $\begin{array}{l}\mathrm{Kan}^{\mathrm{r}} \text {; an artificial binary vector for plant } \\
\text { transformations }\end{array}$ & $\begin{array}{l}\text { Bevan, } 1984 \\
\text { U12540 }\end{array}$ \\
\hline $\begin{array}{l}\text { pBin-HBT-TGA2.1- } \\
\text { GFP }\end{array}$ & $\begin{array}{l}\text { pBIN19 derivative; } \operatorname{Kan}^{\mathrm{r}} \text {; contains the } \\
\text { HBT::TGA2.1-GFP::nos cassette; a } \\
\text { vector for stable transformation of plants }\end{array}$ & see 3.4.3.1 \\
\hline $\begin{array}{l}\text { pBin-HBT-TGA2.2- } \\
\text { GFP }\end{array}$ & $\begin{array}{l}\text { pBIN19 derivative; Kan }{ }^{\mathrm{r}} \text {; contains the } \\
\text { HBT::TGA2.2-GFP::nos cassette; a } \\
\text { vector for stable transformation of plants }\end{array}$ & see 3.4.3.2 \\
\hline $\begin{array}{l}\text { pBin-HBT-TGA1a- } \\
\text { GFP }\end{array}$ & $\begin{array}{l}\text { pBIN19 derivative; contains the } \\
\text { HBT::TGA1a-GFP::nos cassette; a vector } \\
\text { for stable transformation of plants }\end{array}$ & see 3.4 .3 .3 \\
\hline pBin-HBT-TetR-GFP & $\begin{array}{l}\text { pBIN19 derivative; contains the } \\
\text { HBT::TetR-GFP::nos cassette; a vector } \\
\text { for stable transformation of plants }\end{array}$ & see 3.4.3.4 \\
\hline
\end{tabular}


pCHS-GFP-TGA1aC pUC19 derivative; contains an fusion protein of chalcone synthase, mGFP and the C-terminus (198-359 a.a.) of TGA1a; a vector for transient expression

pCHS-GFP-TGA1aN pUC19 derivative; contains an in-frame fusion protein of chalcone synthase, mGFP and the N-terminus (1-146 a.a.) of TGA1a; a vector for transient expression pCHS-GFP-TGA2.2C pUC19 derivative; contains a fusion protein of chalcone synthase, $\mathrm{mGFP}$ and the C-terminus of TGA2.2(274-333 a.a.); a vector for transient expression pCHS-GFP-TGA2.2CLeuMut

pCHS-GFP-TGA2.2N

pGAD-TGA2.2

pGBT-TGA2.1

pGEM®-T

pGEX-4T-1

pGEX-4T-1-TGA2.1C

pGEX-4T-1-TGA2.2C

pGFP-TGA2.1
pUC19 derivative; contains an fusion protein of chalcone synthase, mGFP and the C-terminus of TGA2.2 with 2 Leu ? Gly exchanges; for transient expression pUC19 derivative; contains an in-frame fusion of chalcone synthase, mGFP and the N-terminus (1-91 a.a.) of TGA2.2; a vector for transient expression pGAD424 derivative; Amp ${ }^{\mathrm{r}}$; contains an in-frame fusion of GAL4 activation domain with TGA2.2 pGBT9 derivative; $\mathrm{Amp}^{\mathrm{r}}$; contains an inframe fusion of GAL4 DNA-binding domain with TGA2.1

pGEM-5Zf(+) derivative; Ampr ; 3'-dT overhangs were added after linearization of the plasmid with Eco RV; a vector for cloning and sequencing of PCR products lacI ${ }^{\mathrm{q}}$; Amp ${ }^{\mathrm{r}}$; contains the GST gene under the control of the IPTG-inducible $t a c$ promoter; a vector for constr uction of GST-fused recombinant proteins

pGEX-4T-1 derivative, contains the sequence for the GST-TGA 2.1-C terminus fusion protein ; a vector for recombinant expression of TGA2.1C antigen pGEX-4T- 1 derivative, contains the sequence for the GST-TGA 2.2-C terminus fusion protein; a vector for recombinant expression of TGA2.2C pUC19 derivative; contains an in-frame fusion of mGFP4 with the $\mathrm{N}$-terminus of TGA2. 1; a vector for transient expression
Merkle, unpublished

Merkle, unpublished

Merkle, unpublished

see 3.4.1.9

Merkle, unpublished

Thurow, 2001

Thurow, 2001

Promega

Amersham Pharmacia U13853

see 3.7.1.1

see 3.7.1.1

see 3.4.1.7 
pGFP-TGA2.2

pHBT-Gus

pHBT-GFP

pHBT-L-GFP

pHBT-TGA2.1

pHBT-TGA2.1-GFP

pHBT-TGA2.2

pHBT-TGA2.2-GFP

pHBT-TGA1a-GFP

pHBT-TetR-GFP

pK2.1L
pUC19 derivative; contains an in-frame fusion of mGFP4 with the $\mathrm{N}$-terminus of TGA2.2; a vector for transient expression pHBT-L-GFP derivative, the GFP coding sequence replaced by the $\beta$-glucoronidase gene

pUC18 derivative; Amp ${ }^{\mathrm{r}}$; contains the coding sequence of a synthetic, optimized codon-usage GFP (S65T) under the control of the chimeric HBT promoter and with nos termination signal;

pHBT-GFP derivative; Amp ; contains a inserted linker with $K p n \mathrm{I}, E c o \mathrm{RV}$ and

BamHI restriction sites in front of the ATG of GFP (S65T); a vector for cloning of C-terminal TGA-GFP fusions

pHBT-L-GFP derivative, GFP coding sequence replaced by the TGA2.1 cDNA; a vector for transient expression in plants pHBT-L-GFP derivative; Amp ${ }^{\mathrm{r}}$; contains the sequence of the fusion protein TGA2.1-GFP under the HBT promoter and with the nos terminator; a vector for transient expression in plants pHBT-L-GFP derivative, GFP coding sequence replaced by the TGA2.2 cDNA; a vector for transient expression in plants pHBT-L-GFP derivative; Amp ${ }^{\mathrm{r}}$; contains the sequence of the fusion protein TGA2.2-GFP under the HBT promoter and with the nos terminator; a vector for transient expression in plants pHBT-L-GFP derivative; Amp ${ }^{\mathrm{r}}$; contains the sequence of the fusion protein

TGA1a-GFP under the HBT promoter and with the nos terminator; a vector for transient expression in plants

pHBT-L-GFP derivative; Amp ${ }^{\mathrm{r}}$; contains the sequence of the fusion protein TetRGFP under the HBT promoter and with the nos terminator; a vector for transient expression in plants

pUC57 derivative, Amp ${ }^{\mathrm{r}}$; contains TGA2.1 as a KpnI / BamHI fragment (5' - Kozak sequence - TGA2.1 - peptide linker - 3') see 3.4.1.8

Thurow, 2001

Chui et al., 1996

kindly provided by

Dr. W Droege -

Laser

see 3.4.1.2

Thurow, 2001

see 3.4.1.3

Thurow, 2001

see 3.4.1.4

see 3.4.1.5

see 3.4.1.6

Lenk, 2001 


\begin{tabular}{|c|c|c|}
\hline pK2.2L & $\begin{array}{l}\text { pSK derivative, } \mathrm{Amp}^{\mathrm{r}} \text {; contains TGA2.2 } \\
\text { as a KpnI / BamHI fragment }\left(5^{\prime}-\text { Kozak }\right. \\
\left.\text { sequence - TGA2.2 - peptide linker - } 3^{\prime}\right)\end{array}$ & Lenk, 2001 \\
\hline pUC18 & $\begin{array}{l}2686 \mathrm{bp} ; \mathrm{Amp}^{\mathrm{r}} \text {; blue-white selection } \\
\text { (lacZa); a vector for cloning and } \\
\text { sequencing }\end{array}$ & $\begin{array}{l}\text { Pharmacia } \\
\text { L09136 }\end{array}$ \\
\hline pUC18 as-1 BpiI & $\begin{array}{l}\text { pUC18 derivative, contains the as }-1 \\
\text { fragment from the } 35 \mathrm{~S} \text { promoter (for } \\
\text { EMSAs) }\end{array}$ & Kegler, 2001 \\
\hline pUC19 & $\begin{array}{l}\text { Same as pUC18, only multiple cloning } \\
\text { site (MCS) inverted }\end{array}$ & $\begin{array}{l}\text { Pharmacia } \\
\text { L09137 }\end{array}$ \\
\hline pUC19-CHS-GFP & $\begin{array}{l}\text { pUC19 (pBI221) derivative, } \mathrm{Amp}^{\mathrm{r}} \text {; } \\
\text { contains the sequence for the chalcone } \\
\text { synthase-mGFP4 fusion under the control } \\
\text { of the } 35 \mathrm{~S} \text { promoter; a vector for transient } \\
\text { expression of fusions of the N- or C- } \\
\text { terminal domains of the TGA factors }\end{array}$ & $\begin{array}{l}\text { kindly provided by } \\
\text { Dr. T Merkle }\end{array}$ \\
\hline pUC19-GFP & $\begin{array}{l}\text { pUC19 (pBI221) derivative; Amp }{ }^{r} \text {; } \\
\text { contains the mGFP4 gene under the } \\
\text { control of the } 35 \text { S promoter; a vector for } \\
\text { creating N-terminally GFP-tagged TGA } \\
\text { fusion proteins }\end{array}$ & $\begin{array}{l}\text { kindly provided by } \\
\text { Dr. T Merkle }\end{array}$ \\
\hline pUC57/T & $\begin{array}{l}2712 \mathrm{bp} \text {; Amp }{ }^{\mathrm{r}} \text {; } \text { '-dT overhangs added } \\
\text { after linearization with Eco32I; a blue- } \\
\text { white selection (lacZa); a vector for } \\
\text { cloning and sequencing of PCR products }\end{array}$ & $\begin{array}{l}\text { MBI Fermentas } \\
\text { Y14837 }\end{array}$ \\
\hline pUC57-TGA1a-3' & $\begin{array}{l}\text { pUC57 derivative, contains the C- } \\
\text { terminus of TGA1a as a Eco147I / } \\
\text { Eco } 105 \text { I fragment }\end{array}$ & see 3.4.1.5 \\
\hline pUC57-TGA1a-5' & $\begin{array}{l}\text { pUC57 derivative, contains the } \mathrm{N}- \\
\text { terminus of TGA1a as a PCR fragment }\end{array}$ & see 3.4.1.5 \\
\hline pUC57-TGA1a-5’3' & $\begin{array}{l}\text { pUC57 derivative, contains a } \\
\text { reconstructed full-length TGA1a between }\end{array}$ & see 3.4.1.5 \\
\hline pUC-TetR-VP16 & $\begin{array}{l}\text { Acc } 65 \mathrm{I} \text { and } \text { BamHI sites } \\
\text { pUC derivative; Amp }{ }^{\mathrm{r}} \text {; contains the gene } \\
\text { fragments for an in-frame fusion between } \\
\text { the } 1-207 \text { aminoacids of the bacterial } \\
\text { tetracycline repressor (TetR) and the } 363 \text { - } \\
490 \text { aminoacids (the activation domain) of } \\
\text { VP16 }\end{array}$ & $\begin{array}{l}\text { Weinmann et al., } \\
1994\end{array}$ \\
\hline
\end{tabular}


2.6. Proteins

2.6.1. Antibodies

\begin{tabular}{|c|c|c|c|}
\hline Antibody & Specificity against & Properties & Reference \\
\hline a-rabbit IgG & rabbit immunoglobulin $\mathrm{G}$ & $\begin{array}{l}\text { donkey polyclonal, } \\
\text { peroxidase conjugate }\end{array}$ & Amersham \\
\hline a-TBP & TFIID (TBP) p36 & $\begin{array}{l}\text { rabbit polyclonal, } \\
\text { Affinity-purified }\end{array}$ & \\
\hline a-TGA2.X-C & C-termini of TGA $2.1 / 2.2$ & $\begin{array}{l}\text { rabbit polyclonal, } \\
\text { affinity-purified }\end{array}$ & see 3.7 .1 \\
\hline a-TGA2.1-N & N-terminus of TGA2.1 & $\begin{array}{l}\text { rabbit polyclonal, } \\
\text { affinity-purified }\end{array}$ & Niggeweg, 1999 \\
\hline a-TGA7 & N-terminus of TGA 7 & $\begin{array}{l}\text { rabbit polyclonal, } \\
\text { affinity-purified }\end{array}$ & Schiermeyer, 2001 \\
\hline
\end{tabular}

\subsubsection{Enzymes}

\section{Enzyme \\ Calf intestine alkaline phosphatase (CIAP) \\ Cellulase "Onozuka R-10" \\ DNA restriction enzymes type II}

Klenow fragment (DNA polymerase I large fragment)

Klenow fragment exo' (3'? 5' and 5'? 3' exonuclease minus)

Macerozyme R-10

Pectinase

RNase A (DNase-free)

T4 DNA ligase

$\mathrm{T} 4$ polynucleotide kinase (PNK)

Taq DNA polymerase

\section{Manufacturer \\ MBI Fermentas \\ Serva \\ MBI Fermentas \\ Gibco BRL}

New England Biolabs

MBI Fermentas

MBI Fermentas

Serva

Fluka

Qiagen

MBI Fermentas

MBI Fermentas

MBI Fermentas

\subsubsection{Protein standards}

The BenchMark ${ }^{\mathrm{TM}}$ Prestained Protein Ladder, $\sim 10-200 \mathrm{kDa}$ (Invitrogen) and the Prestained Protein Ladder, 10-160 kDa (MBI Fermentas) were used for the estimation of the approximate molecular weights of proteins on SDS-PAGE, according to the information provided by the manufacturer for each batch of protein standard. 
2.7. Organisms

2.7.1. Bacteria

\begin{tabular}{|c|c|c|}
\hline Strain & Description & Reference \\
\hline $\begin{array}{l}\text { Escherichia coli } \\
\text { DH5a }\end{array}$ & $\begin{array}{l}\mathrm{F}, \text { gyr } \mathrm{A} 96(\mathrm{Nalr}), \operatorname{rec} \mathrm{A} 1, \text { relA1, } \\
\text { end } \mathrm{A} 1, \text { thi-1, hsd } \mathrm{R} 17\left(\mathrm{r}_{\mathrm{k}}-\mathrm{m}_{\mathrm{k}}+\right), \\
\text { gln } \mathrm{V} 44, \text { deo } \mathrm{R}, \mathrm{D}(\text { lac ZYA-arg } \mathrm{F}) \\
\mathrm{U} 169 \text { [p80dD }(\text { lac } \mathrm{Z}) \mathrm{M} 15] \\
\text { strain for cloning and sequencing }\end{array}$ & Hanahan, 1983 \\
\hline $\begin{array}{l}\text { Escherichia coli } \\
\text { XL1-Blue }\end{array}$ & 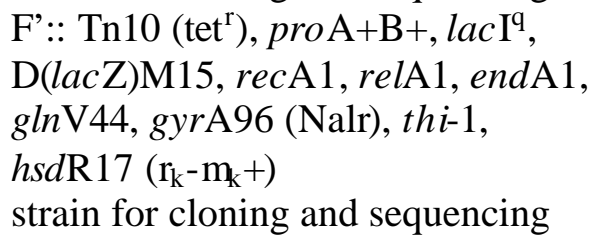 & Bullock et al, 1987 \\
\hline $\begin{array}{l}\text { Escherichia coli } \\
\text { W3110 } \\
\text { Agrobacterium tumefaciens } \\
\text { pGV2660 C58-C1-R }\end{array}$ & $\begin{array}{l}\mathrm{F}^{\prime}, \operatorname{lac} \mathrm{I}^{\mathrm{q}} \mathrm{L}_{8}, h s d \mathrm{R}-, \text { hsd } \mathrm{M}+ \\
\text { strain for expression of } \mathrm{GST} \text {-fusions } \\
\text { Rif }^{\mathrm{R}}, \mathrm{Cm}^{\mathrm{R}} \\
\text { strain for stable plant transformation }\end{array}$ & $\begin{array}{l}\text { Brent \& Ptashne, } \\
1981 \\
\text { Deblaere et al., } \\
1985\end{array}$ \\
\hline
\end{tabular}

2.7.2. Plants

Nicotiana tabacum wild-type plants from the cultivar Samsun NN (SNN) were used. Transgenic plants are listed bellow:

$\begin{array}{lll}\text { Plant } & \text { Description } & \text { Reference } \\ \text { as-1 ::Gus } & \text { SNN, as-1::Gus, Ppt } & \text { Kegler, 2001 } \\ \text { TGA2.1 OE } & \text { SNN, CaMV 35S::TGA2.1, } \mathrm{Hyg}^{\mathrm{R}} & \text { Kegler, 2001 } \\ \text { TGA2.2 OE } & \text { SNN, CaMV 35S::TGA2.2, } \mathrm{Hyg}^{\mathrm{R}} & \text { Niggeweg, 1999 } \\ \text { TGA7 OE } & a s-1:: G u s, \text { TX::TGA7, Hyg } & \text { Schiermeyer, 2001 } \\ \text { TGA2.1-GFP } & \text { SNN, HBT::TGA2.1-GFP, Kan } & \text { see 3.4.3 } \\ \text { TGA2.2-GFP } & \text { SNN, HBT::TGA2.2-GFP, Kan } & \text { see 3.4.3 } \\ \text { TGA1a-GFP } & \text { SNN, HBT::TGAla-GFP, } \operatorname{Kan}^{\mathrm{R}} & \text { see 3.4.3 } \\ \text { TetR-GFP } & \text { SNN, HBT::TetR-GFP }, \operatorname{Kan}^{\mathrm{R}} & \text { see 3.4.3 }\end{array}$


2.8. Kits

Kit

BigDye $^{\mathrm{TM}}$ Enhanced Terminators (ET) Cycle Sequencing Kit Enhanced Chemiluminescence Plus ${ }^{\mathrm{TM}}(\mathrm{ECL}+) \mathrm{Kit}$ GeneClean® II Kit

pGEM®- T vector system Kit

QIAGEN® QIAfilter ${ }^{\mathrm{TM}}$ Midi-/Maxi- Kits

QIAquick ${ }^{\circledR}$ Gel Extraction Kit

RNeasy® Plant Mini Kit

pUC57/T-cloning Kit

\section{Manufacturer}

Perkin-Elmer

Amersham Biosciences

Q-BIOgene

Promega

QIAGEN

QIAGEN

QIAGEN

MBI Fermentas

\subsection{Software}

$\begin{array}{ll}\text { Program } & \text { Company / Organization } \\ \text { Acrobat Reader } & \text { Adobe } \\ \text { BLAST } & \text { NCBI } \\ \text { CorelDRAW } & \text { Corel } \\ \text { LSM software } & \text { Zeiss } \\ \text { Office } & \text { Microsoft } \\ \text { Open Office } & \text { OpenOffice.org } \\ \text { PC-BAS Reader } & \text { Raytest GmbH } \\ \text { PhotoPaint } & \text { Corel } \\ \text { PhotoShop } & \text { Adobe } \\ \text { TINA } & \text { Raytest GmbH } \\ \text { Vector NTI } & \text { InforMax Inc. }\end{array}$




\section{Methods}

\subsection{Cultivation of organisms}

\subsubsection{Cultivation of bacteria}

Bacterial strains were grown on media containing appropriate selective antibiotics in order to favor the development only of colonies carrying plasmids with the resistance gene. The liquid cultures were agitated at $250 \mathrm{rpm}$ on a shaker. The number of cells was determined by measuring the optical density of the culture at $600 \mathrm{~nm}\left(\mathrm{OD}_{600}\right)$, at which a value of 0.1 corresponds to a number of $2 \times 10^{7} \mathrm{E}$. coli cells per ml. Aliquots from the cultures were preserved at $-80^{\circ} \mathrm{C}$ as glycerol stocks $(25 \%$ glycerol final concentration).

Escherichia coli strains were grown overnight either on solid or in liquid LB or dYT medium at $37^{\circ} \mathrm{C}$.

Agrobacterium tumefaciens strains were cultivated at $28^{\circ} \mathrm{C}$ on YEB medium. The cultivation of this species requires 2 days in general.

\subsubsection{Cultivation of Nicotiana tabacum}

Bright Yellow - 2 (BY-2) tobacco cell suspension cultures were cultivated in darkness at $26^{\circ} \mathrm{C}$ and $120 \mathrm{rpm}$ agitation in a modified MS medium, containing $3 \%$ sucrose, 0.9 $\mathrm{g} / \mathrm{l}$ myo-inositol, $0.9 \mathrm{mg} / \mathrm{l}$ thiamine and $0.22 \mathrm{mg} / \mathrm{l}$ 2,4-D. Cultures were sub-cultured every week by adding an aliquot of $3 \mathrm{ml}$ of the old culture to $27 \mathrm{ml}$ fresh medium.

Sterile cultures from $N$. tabacum were grown in glasses on solid MS medium (Murashige and Skoog, 1962) in a climate chamber at a cycle of a light phase (16 hours at $24^{\circ} \mathrm{C}$ ) and a dark phase $\left(8\right.$ hours at $22^{\circ} \mathrm{C}$ ). For sub-culturing, the apical part of the plant was cut and transferred to a glass with fresh medium for forming new roots.

For the large amounts of leaf tissue necessary for protein extracts, non-sterile plants were grown either as hydroponics or in soil. For hydroponics, plants were removed from the sterile glasses, the roots were rinsed under running water to remove the MS medium and the plants were set with their roots dipped in black plastic boxes in hydroponics medium. The plants were cultivated in a climate chamber under a cycle of 16 hours light at $22^{\circ} \mathrm{C}$ and 8 hours darkness at $19^{\circ} \mathrm{C}$, with $85 \%$ air humidity. The first several days plants were kept covered for easier adaptation to open-air circulation. During the cultivation, the medium was constantly aerated with an aquarium pump.

The plants intended to be grown in soil had their roots rinsed and then were transferred into pots with autoclaved soil. After explanting, they were grown in the same climate chamber as the hydroponics. For seed collection, the plants were transferred to a greenhouse and their flowers were covered for self-pollination. 


\subsection{Isolation, purification, quantification and manipulation of nucleic acids}

\subsubsection{Isolation of nucleic acids}

\subsubsection{Analytical-scale preparation of plasmid DNA from E. coli}

For analytical purposes, plasmid DNA was prepared using a modification of the alkaline lysis method (Le Gouill et al., 1994). A $1.5 \mathrm{ml}$ aliquot of an overnight $E$. coli culture was pelleted in a table-top centrifuge (Biofuge Pico, $3 \mathrm{~min}, 5000 \mathrm{rpm}$ ), the supernatant was discarded, and the cells were resuspended in $100 \mu \mathrm{l}$ of buffer I ( 25 $\mathrm{mM}$ Tris- $\mathrm{HCl}, \mathrm{pH} 8.0 ; 10 \mathrm{mM}$ EDTA; $100 \mu \mathrm{g} / \mathrm{ml} \mathrm{RNAseA).} \mathrm{The} \mathrm{bacteria} \mathrm{were} \mathrm{lysed}$ with the addition of $200 \mu \mathrm{l}$ of buffer II $(0.2 \mathrm{M} \mathrm{NaOH} ; 1 \%$ (w/v) SDS) and $200 \mu \mathrm{l}$ chloroform and incubated for $5 \mathrm{~min}$. The solution was neutralized with $150 \mu \mathrm{l}$ of buffer III (29.4 g potassium acetate; $5 \mathrm{ml}$ glacial acetic acid; $\mathrm{H}_{2} \mathrm{O}$ until $100 \mathrm{ml}$ ), the sample was vortexed for $3 \mathrm{sec}$ and centrifuged for $2 \mathrm{~min}$ at $13000 \mathrm{rpm}$. Without disturbing the precipitate in the interphase, the upper watery phase (approx. $400 \mu \mathrm{l}$ ) was transferred into a new Eppendorf tube and plasmids were precipitated according to Sambrook et al., 1989. DNA-containing upper phase was mixed with 2.5 volumes of ice-cold $96 \%$ (v/v) ethanol. After a centrifugation for $15 \mathrm{~min}$ at $13000 \mathrm{rpm}$, the sedimented plasmid DNA was washed with $70 \%(\mathrm{v} / \mathrm{v})$ ethanol, centrifuged again for 5 min and the DNA pellet was dried at room temperature. The plasmid DNA was dissolved in $20 \mu \mathrm{l}$ of $10 \mathrm{mM}$ Tris- $\mathrm{HCl}, \mathrm{pH} 8.5$ and used further for restriction analysis (1-3 $\mu 1$ per digestion).

\subsubsection{Large-scale preparation of plasmid DNA}

For the preparation of larger amounts of high-purity plasmid DNA QIAfilter® Midiand Maxi- kits from QIAGEN were used. The procedure was performed according to the manufacturer's instructions (QIAGEN® Plasmid Purification Handbook, 2000).

\subsubsection{Isolation of total RNA from N. tabacum leaves}

Preparations of total RNA from leaf tissues were performed with the Plant RNeasy® Mini-kit from QIAGEN. Approximately $150 \mu \mathrm{g}$ of leaf tissue were flash-frozen in liquid $\mathrm{N}_{2}$ and ground to powder with a mortar and a pestle. The powder was transferred into a $1.5 \mathrm{ml}$ Eppendorf tube and thawed in $450 \mu \mathrm{l}$ of buffer RLT (all buffers were supplied with the kit) containing freshly-added $10 \mu \mathrm{l} / \mathrm{ml} \quad \beta$ mercaptoethanol. The sample was vortexed, applied on a QIAshredder column and centrifuged for $5 \mathrm{~min}$ at $13000 \mathrm{rpm}$ in a table-top (Heraeus Biofuge Pico) for the elimination of the cell debris. The supernatant was mixed with 0.5 volumes of ethanol and applied onto an RNeasy Mini column. During the centrifugation (15 sec, 10000 rpm, Biofuge Pico) the RNAs were bound to the column matrix. The column was then washed once with $700 \mu 1$ of buffer RW1 and twice with $500 \mu 1$ of buffer RPE and the RNA was eluted from the matrix by adding twice $30 \mu 1$ of RNAse-free $\mathrm{H}_{2} 0$.

\subsubsection{Estimation of the concentration and purity of nucleic acids}

The concentration of DNA and RNA samples was determined with a spectrophotometer (GeneQuant, Pharmacia) measuring the absorption of 100-fold diluted samples in a quartz cuvette at $260 \mathrm{~nm}$ (at this wavelength the nucleic acids 
have an absorption maximum due to the p-electron systems of the heterocycles of the nucleotides). An $\mathrm{OD}_{260}=1.0$ in case of a $1 \mathrm{~cm}$ cuvette corresponds to $50 \mu \mathrm{g} / \mathrm{ml}$ doublestranded DNA and to $40 \mu \mathrm{g} / \mathrm{ml}$ RNA. An additional measurement of the absorption at $280 \mathrm{~nm}$, where the aromatic rings of the some amino acids and phenol compounds have an absorption maximum, gives information about the purity of the DNA/RNA sample - the optimal ratio $\mathrm{OD}_{260} / \mathrm{OD}_{280}$ is in the range of 1.9-2.0 for RNA and 1.8 for DNA. For estimations of DNA samples with a concentration lower than $100 \mathrm{ng} / \mu \mathrm{l}$, a direct comparison to a known DNA concentration standard on an agarose gel was performed, having in mind that the amount of intercalated $\mathrm{EtBr}$ is proportional to the concentration and the length of the DNA sample.

\subsubsection{Restriction digestion of DNA molecules}

Sequence-specific digestions of DNA were performed with diverse restriction endonucleases type II, which leave fragments with 5' or 3' "sticky" overhangs or blunt ends after the digestion; the reactions were set in buffers optimized for the enzyme(s) and supplied by the manufacturer (most often MBI Fermentas):

\begin{tabular}{|c|c|c|c|c|}
\hline Buffer B+ & Buffer G+ & Buffer O+ & Buffer R+ & Buffer Y+ \\
\hline $10 \mathrm{mM}$ Tris $-\mathrm{HCl}$ & $10 \mathrm{mM}$ Tris $-\mathrm{HCl}$ & $50 \mathrm{mM}$ Tris $-\mathrm{HCl}$ & $10 \mathrm{mM}$ Tris $-\mathrm{HCl}$ & $33 \mathrm{mM}$ Tris $-\mathrm{Ac}$ \\
\hline$\left(\mathrm{pH} 7.5\right.$ at $\left.37^{\circ} \mathrm{C}\right)$ & $\left(\mathrm{pH} 7.5\right.$ at $\left.37^{\circ} \mathrm{C}\right)$ & $\left(\mathrm{pH} 7.5\right.$ at $\left.37^{\circ} \mathrm{C}\right)$ & $\left(\mathrm{pH} 8.5\right.$ at $\left.37^{\circ} \mathrm{C}\right)$ & $\left(\mathrm{pH} 7.9\right.$ at $\left.37^{\circ} \mathrm{C}\right)$ \\
\hline $10 \mathrm{mM} \mathrm{MgCl}_{2}$ & $10 \mathrm{mM} \mathrm{MgCl}_{2}$ & $10 \mathrm{mM} \mathrm{MgCl}_{2}$ & $10 \mathrm{mM} \mathrm{MgCl}_{2}$ & $10 \mathrm{mM} \mathrm{Mg}-\mathrm{Ac}$ \\
\hline \multirow[t]{2}{*}{$0.1 \mathrm{mg} / \mathrm{ml} \mathrm{BSA}$} & $50 \mathrm{mM} \mathrm{NaCl}$ & $100 \mathrm{mM} \mathrm{NaCl}$ & $100 \mathrm{mM} \mathrm{KCl}$ & $66 \mathrm{mM} \mathrm{K}-\mathrm{Ac}$ \\
\hline & $0.1 \mathrm{mg} / \mathrm{ml} \mathrm{BSA}$ & $0.1 \mathrm{mg} / \mathrm{ml} \mathrm{BSA}$ & $0.1 \mathrm{mg} / \mathrm{ml} \mathrm{BSA}$ & $0.1 \mathrm{mg} / \mathrm{ml} \mathrm{BSA}$ \\
\hline
\end{tabular}

The activity of the restriction enzymes is estimated in Units (U), where $1 \mathrm{U}$ stands for the amount of enzyme cutting completely at optimal conditions $1 \mu \mathrm{g}$ of ? DNA for 60 min. The minimal amount of enzyme necessary for each restriction was determined according to the following formula:

$$
\mathrm{U}_{\min }=[\mathrm{bp}(?) \mathrm{x} \text { recognition sites (DNA) }] /[\text { recognition sites (?) } \mathrm{x} \text { bp (DNA) }]
$$

The restriction digestions were performed in a volume of 10-20 $\mu 1$ and incubated for 1-2 hours at $37^{\circ} \mathrm{C}$, a temperature which is optimal for most of the restriction enzymes; then the reactions were inactivated by incubation at $65^{\circ} \mathrm{C}$ or $80^{\circ} \mathrm{C}$ for $10 \mathrm{~min}$ depending on the enzyme(s) used, and the products were analyzed on agarose gel.

\subsubsection{Fill-in of 3'-overhangs with Klenow fragment of DNA polymerase I}

The Klenow fragment of DNA polymerase I from E. coli has a 5'? 3' polymerase activity, i.e. it can incorporate nucleotides in 5'? 3' direction on 3'- termini templates, which can be used for integrating a labeled nucleotide into the DNA fragment (labeling), converting sticky overhangs into blunt ends for cloning purposes (filling-in), etc. Reactions were performed in an optimal buffer for the enzyme, supplied by the manufacturer as $10 \mathrm{x}(500 \mathrm{mM}$ Tris- $\mathrm{HCl} \mathrm{pH} 8.0,50 \mathrm{mM} \mathrm{MgCh}, 10$ $\mathrm{mM}$ DTT) using a mix of $2 \mathrm{mM}$ dNTPs (radioactively-labeled dNTPs were added separately) at a final concentration of $0.25 \mathrm{mM}$; the reactions were incubated for 1-2 hours at $37^{\circ} \mathrm{C}$ and stopped either by heating them at $65^{\circ} \mathrm{C}$ for $10 \mathrm{~min}$ (for filling-in) or by $\mathrm{EtOH}$ precipitation of the DNA fragments (for radioactive labeling). 


\subsubsection{Dephosphorylation / phosphorylation of DNA fragments}

To prevent the self-enclosure of a vector in a subsequent ligation (e.g. when a plasmid was only linearized with a single restriction enzyme) a hydrolysis of the 5'-terminal phosphate residue (dephosphorylation) was performed using calf intestine alkaline phosphatase (CIAP) in a $10 \mathrm{mM}$ Tris- $\mathrm{HCl} \mathrm{pH} 7.5$ at $37^{\circ} \mathrm{C}, 10 \mathrm{mM} \mathrm{MgCb}$ buffer (or in the buffer used for restriction) for $30 \mathrm{~min}$ at $37^{\circ} \mathrm{C}$. The reaction was stopped by heating the sample at $85^{\circ} \mathrm{C}$ for $15 \mathrm{~min}$ and the DNA fragments were purified from agarose gels.

When an addition of a phosphate residue to the terminal 5'-OH-group of DNA fragments was necessary (e.g. in case that synthetic oligonucleotides were to be cloned in plasmids) a phosphorylation with a T4 polynucleotide kinase (PNK) (3'phosphatase $\left.\mathrm{e}^{-}\right)$was performed in buffer A for forward reaction $(50 \mathrm{mM}$ Tris- $\mathrm{HCl} \mathrm{pH}$ 7.6, $10 \mathrm{mM} \mathrm{MgCb}, 5 \mathrm{mM}$ DTT, $0.1 \mathrm{mM}$ Spermidine, $0.1 \mathrm{mM}$ EDTA) supplied by MBI Fermentas. The reaction was incubated at $37^{\circ} \mathrm{C}$ for $30 \mathrm{~min}$ and inactivated by heating the sample for $15 \mathrm{~min}$ at $65^{\circ} \mathrm{C}$.

\subsubsection{Hybridization of single-stranded into double-stranded oligonucleotides}

For the purpose of cloning the TGA factors in front of the GFP (S65T) gene in the pHBT-GFP plasmid, a linker containing recognition sites for the Acc65I and EcoRV restriction enzymes was inserted immediately before the starting ATG of GFP, using an available BamHI restriction site (reconstituted after the insertion of the oligoduplex only at the 3'-end of the linker). For the formation of the double-stranded oligoduplex, the single-stranded oligonucleotides were mixed in equimolar proportions, heated at $95^{\circ} \mathrm{C}$ on a water bath for $15 \mathrm{~min}$ and allowed to cool down at room temperature.

\subsubsection{Gel electrophoresis of nucleic acids}

\subsubsection{Separation of DNA fragments on agarose gels}

For analytical or preparative purposes, DNA fragments were separated by electrophoresis in $1 \times$ TAE buffer on horizontal agarose gels $(10 \times 7 \times 0.3 \mathrm{~cm})$ with different concentrations (1\% (w/v) Agarose in 1 x TAE for fragments between 500 bp and $12 \mathrm{~kb}$, and $2 \%$ gels for fragments smaller than $500 \mathrm{bp}$ ). The samples were mixed with $1 / 10$ volume $10 \times$ DNA loading buffer, loaded on the gel and subjected to electric current $3 \mathrm{~V}$ per $\mathrm{cm}$ distance between the electrodes for 1.5-2 hours according to the migration of the Orange $\mathrm{G}$, Bromphenolblue and Xylenecyanol FF dyes. After electrophoresis the gel was incubated for $10 \mathrm{~min}$ in a $1 \mathrm{mg} / \mathrm{l} \mathrm{EtBr}$ solution (in $\mathrm{H}_{2} \mathrm{O}$ ) for making the DNA fragments visible under UV, rinsed briefly in $\mathrm{H}_{2} \mathrm{O}$ for removing the background staining of the gel, fragments were visualized on a UV-transilluminator and documented with a gel-documentation station. The estimation of the sizes and amount of the DNA fragments was done by comparing them to fragments with known size (DNA standards, see 2.5.1.6). 


\subsubsection{Separation of RNA on denaturing agarose gels}

Electrophoretic separation of RNAs was performed on denaturing $1 \%(\mathrm{w} / \mathrm{v})$ agarose gels containing $5.5 \%(\mathrm{v} / \mathrm{v})$ formaldehyde in $1 \mathrm{x}$ MEN as buffer, in order to prevent the formation of secondary structures which affect the mobility of the RNA molecules in the gel. Total RNA was prepared from frozen leaf tissues (3.2.1.3), the concentrations were determined spectrophotometrically (3.2.1.4), samples with equalized RNA amounts (in the range of 5-20 $\mu \mathrm{g}$ ) in equal volumes of RNase-free $\mathrm{H}_{2} \mathrm{O}$ were prepared with the addition of $3 \times$ RNA loading buffer (containing $1 \mu \mathrm{g}$ EtBr per sample) and brought up to $60 \mu \mathrm{l}$ for gels with small pockets (for 20 samples) or respectively up to $75 \mu \mathrm{l}$ for gels with large pockets (for 15 samples). The RNA probes were denatured by incubation at $65^{\circ} \mathrm{C}$ for $10 \mathrm{~min}$ and immediately transferred and stored on ice until their loading on the gel. The electrophoresis was run at $300 \mathrm{~V}$, $500 \mathrm{~mA}, 12 \mathrm{~W} / \mathrm{gel}, 0.20 \mathrm{kVh}$ until the bromphenolblue dye was $2-3 \mathrm{~cm}$ from the end of the gel and the separation of the RNAs was visualized on a UV-trans-illuminator and photographed.

\subsubsection{Recovery of DNA molecules from agarose gels}

The isolation of DNA fragments from agarose gel slices was done with the QIAquick Gel Extraction Kit (Qiagen). The slice with the desired DNA fragment was excised at UV illumination, its weight was determined and 3 volumes (per slice weight) of QG buffer were added. The tube was incubated at $50^{\circ} \mathrm{C}$ until the gel slice melts, the color of the $\mathrm{pH}$ indicator in the buffer was checked, the sample was applied on a QIAquick column and centrifuged at $13000 \mathrm{rpm}$ for $1 \mathrm{~min}$ in a Biofuge pico table-top, during which DNA molecules bind to the column matrix. The column was washed with 750 $\mu l$ of PE washing solution and centrifuged under the same conditions, including an additional centrifugation step for complete removal of the washing buffer. The DNA was eluted from the column with the addition of $50 \mu \mathrm{l}$ of EB buffer $(10 \mathrm{mM}$ Tris- $\mathrm{HCl}$, $\mathrm{pH} 8.5$ ) and subsequent centrifugation.

\subsubsection{Ligation of DNA fragments}

T4- DNA ligase is able to catalyze the formation of a phosphodiesther chemical bond between free 5'-phosphate and 3'-OH groups of double-stranded DNA fragments, which results in the formation of recombinant DNA molecules. For the ligation of two fragments several conditions have to be fulfilled - the ends must be compatible; at least one of the ends must be phosphorilated; ATP and optimal ligation buffer (supplied as $10 \mathrm{x}$ by MBI Fermentas) are necessary. When one or both ends of the ligated fragments were blunt, $5 \%$ (w/v) PEG-4000 was added in the ligation reaction to increase the efficiency of the ligation process. For the insertion of double-stranded oligonucleotides generally up to $100: 1$ molar ratio of insert : vector was used, while larger DNA inserts were added to the ligation reaction in ratio $410: 1$ (insert : vector). The ligations were performed with 4 units of T4-DNA ligase per $30 \mu 1$ reaction volume either at room temperature for 2 hours or at $16^{\circ} \mathrm{C}$ on a water bath overnight. 


\subsubsection{Polymerase Chain Reaction (PCR)}

Polymerase Chain Reaction (Mullis and Faloona, 1987) is a method for selective in vitro amplification of DNA fragments from a template DNA sequence, using sequence-specific anti-parallel oligonucleotides (primers) flanking the amplified region and a thermostable DNA polymerase (Taq) originally isolated from Thermophyllus aquaticus. At first the two DNA strands of the template are separated and exposed by heat denaturation, thus allowing the recognition and the hybridization (annealing) of the primers with their complementary sequences in the 5' regions of the amplified sequence. In the next step the Taq polymerase catalyzes the elongation of the newly-synthesized chain by complementary polymerization of nucleotides to the free 3'-OH group of the primer. With each next cycle of denaturation-annealingelongation (25-35 cycles optimal) the primer-flanked DNA sequence is exponentially enriched in the reaction. The reaction allows that the primers can be strictly complementary to the template only in their 3'- end and this property can be used for incorporation of suitable synthetic restriction sites at the 5'-end of the PCR products.

A standard polymerase chain reaction mixture of $50 \mu$ l contains:

$\begin{array}{lll}\text { Template plasmid DNA } & 10 & \mathrm{ng} \\ 10 \times \mathrm{Taq} \text { buffer (with } 1.5 \mathrm{mM} \mathrm{MgCh}) & 5 & \mu \mathrm{l} \\ 10 \mathrm{mM} \text { (each) dNTPs } & 1 & \mu \mathrm{l} \\ 10 \mathrm{pmol} / \mu \mathrm{l} \text { primers } & 2.5 & \mu \mathrm{l} \text { each } \\ \text { Taq polymerase } & 2.5 & \mathrm{U} \\ \mathrm{H}_{2} \mathrm{O} & \text { up to } 50 & \mu \mathrm{l}\end{array}$

The amplification process was performed on programmable PCR thermocyclers (Techne or MJ Research) using the following parameters:

$\begin{array}{llllll} & \text { Initial denaturation } & 4 & \min & 94^{\circ} \mathrm{C} & \\ & \text { Denaturation } & 1 & \min & 94^{\circ} \mathrm{C} & \\ 25-35 \times & \text { Annealing } & 30 & \sec & 50-60^{\circ} \mathrm{C} & \text { see } \mathrm{T}_{\text {ann }} \text {, } \\ & \text { Elongation } & 1 & \min / \mathrm{kb} & 72^{\circ} \mathrm{C} & \\ & \text { Final elongation } & 10 & \min & 72^{\circ} \mathrm{C} & \end{array}$

$10 \mu \mathrm{l}$ of the reactions were used for tests on agarose gels.

\subsubsection{Screening bacterial colonies with PCR}

For analytical purposes (e.g. for faster screening for positive clones) PCR was performed on bacterial colonies. Single colonies were picked up with yellow ips, saved on a master plate and the same tip was rinsed in $30 \mu \mathrm{l}$ of $\mathrm{H}_{2} \mathrm{O}$. The samples were boiled for $5 \mathrm{~min}$ at $95^{\circ} \mathrm{C}$, centrifuged for $1 \mathrm{~min}$ at $13000 \mathrm{rpm}$ in a tabletop (Heraeus Biofuge pico) and $5 \mu \mathrm{l}$ of the supernatant were added to the PCR mix containing the appropriate primers and additional $5 \%(\mathrm{v} / \mathrm{v})$ DMSO. 


\subsubsection{Cloning of PCR products}

Besides 5'? 3' polymerase activity, Taq DNA polymerase has also a terminal deoxynucleotidiltransferase activity, which leads to an addition of deoxyadenosine (dA) at the 3'-end of the PCR product. This 3'-dA overhang can be used for a direct cloning of the PCR fragment into vectors having a complementary 3'-deoxytimidine (dT). For this purpose pUC57/T (T-Cloning Kit, MBI Fermentas) and pGEM®-T (Promega) were used; ligations reactions were performed according to the manufacturers' instructions.

\subsubsection{DNA Sequencing}

Sequencing was done using the BigDye ${ }^{\mathrm{TM}}$ Terminator Enhanced Terminators Cycle Sequencing kit from Perkin-Elmer, based on the principle of the chain-termination method (Sanger et al., 1977). According to this method, in the reaction mixture besides deoxynucleotides there are also di-deoxynucleotides (terminators) whose incorporation in the newly-synthesized complementary chain leads to an interruption of its elongation. The four terminators are labeled with different fluorescent dyes and the terminated chains can be specifically detected during a capillary electrophoresis on an ABI Prism 310 Capillary Sequencer (Applied Biosystems). Sequencing reactions were performed in a volume of $10 \mu \mathrm{l}(300 \mu \mathrm{g}$ plasmid DNA, 3-5 pmol primer, $2 \mu \mathrm{l}$ sequencing mix, $\mathrm{H}_{2} 0$ up to $10 \mu \mathrm{l}$ ). The samples were subjected to 25 cycles of: $10 \mathrm{sec}$ at $95^{\circ} \mathrm{C} ; 5 \mathrm{sec}$ at $50^{\circ} \mathrm{C} ; 4 \mathrm{~min}$ at $60^{\circ} \mathrm{C}$ in a thermocycler. The products of the cycle-sequencing reaction were mixed with $1 \mu$ l sodium acetate and $41 \mu \mathrm{l}$ absolute ethanol, incubated on ice for $30 \mathrm{~min}$ and centrifuged for $15 \mathrm{~min}$ at $13000 \mathrm{rpm}$ (Biofuge Pico). The pellet (usually not visible) was washed with $200 \mu 170$ $\%(\mathrm{v} / \mathrm{v})$ ethanol, centrifuged for $5 \mathrm{~min}$ at $13000 \mathrm{rpm}$, the pellet was dried at RT and resuspended in $17 \mu$ l template-suppression reagent (TSR). After a denaturation for 2 min at $95^{\circ} \mathrm{C}$ and immediate cooling on ice, the sample was transferred into a special tube for sequencing and kept on ice until loading on an ABI-Prism ${ }^{\mathrm{TM}} 310$ capillary electrophoresis sequencing station (Perkin-Elmer) for analysis.

\subsection{Gene transfer in prokaryotes}

\subsubsection{Gene transfer in Escherichia coli}

Bacterial cells naturally have no ability to accept naked DNA molecules from the environment, but with different treatments they can be modified artificially to become competent for their transformation with external plasmids and this procedure is widely used in molecular biology, although the mechanisms via which this acquired competency works are still poorly understood. The preparation of different E. coli chemically competent strains was done after Inoue et al., 1990 or after Hanahan, 1983 with modifications, and the transformation was performed according to Hanahan, 1983. A $100 \mu \mathrm{l}$ aliquot of competent cells was thawed on ice, 2-3 $\mu 1$ of a ligation reaction or $0.5-1 \mathrm{ng}$ of plasmid DNA were carefully added, the sample was stirred gently with the pipette tip (without pipetting up and down) and incubated for at least $30 \mathrm{~min}$ on ice. After a heat-shock at $42^{\circ} \mathrm{C}$ for $90 \mathrm{sec}$ the cells were incubated for 5 min on ice, $600 \mu \mathrm{l}$ of dYT medium were added and the sample was incubated for 30 min at $37^{\circ} \mathrm{C}$ on a roller, after which different volumes of cells were plated on Petri dishes with selective solid LB medium and incubated overnight at $37^{\circ} \mathrm{C}$. 


\subsubsection{Gene transfer in Agrobacterium tumefaciens}

A. tumefaciens similar to $E$. coli has no natural competence for DNA acceptance and transfer of plasmid DNA was done by electroporation after Dower et al., 1988. For the preparation of electrocompetent $A$. tumefaciens cells $5 \mathrm{ml}$ of YEB medium were inoculated and incubated ove rnight at $28^{\circ} \mathrm{C}$. With this starter culture $250 \mathrm{ml}$ of YEB was inoculated and incubated at $28^{\circ} \mathrm{C}$ until $\mathrm{OD}_{600}=0.5$, the cells were pelleted, washed three time with ice-cold $\mathrm{H}_{2} \mathrm{O}$ and once with $10 \mathrm{ml}$ ice-cold $15 \%(\mathrm{v} / \mathrm{v})$ glycerol, resuspended in $1 \mathrm{ml} 15 \%(\mathrm{v} / \mathrm{v})$ glycerol and $40 \mu \mathrm{l}$ aliquots were frozen in $\mathrm{N}_{2}$ and stored at $-80^{\circ} \mathrm{C}$. For transformation, an aliquot of frozen cells was thawed on ice and mixed with salt-free plasmid DNA in an ice-cooled electroporation cuvette $(2 \mathrm{~mm}$ electrode distance). The electroporation was performed with a Gene Pulser ${ }^{\circledR}$ II (BioRad) at $25 \mu \mathrm{F}, 2.5 \mathrm{kV}, 200 \mathrm{O}$. After the electroporation $1 \mathrm{ml}$ of SOC medium was added immediately to the cells, they were transferred into Eppendorf tubes, incubated for 2 hours at $28^{\circ} \mathrm{C}$ on a roller, different volumes were plated on Petri dishes with solid YEB medium (with selective antibiotics) and incubated 2 days at $28^{\circ} \mathrm{C}$.

\subsection{Gene transfer in eukaryotes}

\subsubsection{Plasmids for transient expression of diverse fusions of TGA factors with GFP}

For the determination of the subcellular localization of GFP-tagged full-length TGA factors or their separate $\mathrm{N}$ - or C- termini, constructs for transient expression in plant protoplasts were created, driven either by the strong $35 \mathrm{~S}$ promoter from $\mathrm{CaMV}$ or by a chimeric HBT promoter (Sheen, 1993) - the 35S enhancer (HindIII-400 bp-HindIII) fused to the basal promoter of the maize C4PPDK gene (HindIII-TATA-5'UTRBam HI/NcoI). The green fluorescent protein (GFP) we used as a tag was with synthetic optimized codon usage for expression in maize, Arabidopsis, humans, etc. without the cryptic intron discovered in plants (Haseloff et al., 1997) and with the Ser65-Thr (S65T) substitution (Heim and Tsien, 1996) which shifts the excitation and emission spectra of GFP from UV (395(475)/508 nm for the wild-type protein) to blue wavelength $(489 / 511 \mathrm{~nm})$.

\subsubsection{1. pAVA393}

To see whether GFP has localization signals able to influence its targeting to some subcellular compartment we expressed transiently mGFP5 alone under the control of the 35 S promoter (pAVA393, a generous gift from Dr. A. von Arnim).

\subsubsection{2. $p H B T-L-G F P$}

For the construction of C-terminal in-frame fusions of TGA factors with GFP a double-stranded linker (3.2.1.8) of 24 bp with restriction sites for Acc65I (isoschizomer of $K p n I$ ) and EcoRV and with BamHI complementary overhangs (reconstituting the BamHI site only at the 3' end of the linker) was ligated into the pHBT-GFP plasmid (Chui et al., 1996; kindly provided by Dr. W Droege-Laser) linearized with BamHI. 


\subsubsection{3. $p H B T-2.1-G F P$}

For constructing a C-terminal in-frame fusion protein of TGA2.1 with GFP, the coding sequence of TGA2.1 was excised from pK2.1L \#1 as a 1410 bp KpnI / BamHI fragment and ligated into pHBT-L-GFP opened with the same enzymes.

\subsubsection{4. $p H B T-2.2-G F P$}

For constructing a C-terminal in-frame fusion protein of TGA2.2 with GFP, the coding sequence of TGA2.2 was excised from pK2.2L \#1 as a 1005 bp KpnI / BamHI fragment and ligated into pHBT-L-GFP opened with the same enzymes.

\subsubsection{5. $p H B T-1 a-G F P$}

In order to put the TGA1a gene between Acc65I and BamHI restriction sites and to remove a previously introduced PstI site, the 3'-end of TGA1a was cloned as an Eco147I / Eco105I fragment in the Eco147I / SmaI sites of the pUC57 vector and the orientation was selected where the Eco147I site was reconstituted. The 5'-end was cloned as a PCR fragment (see TGA1a-KpnI-ATG and TGA1a-EcoRV-lower-StuI primers) into the pUC57/T cloning kit (MBI Fermentas) and the orientation of the PCR insert where the internal Eco147I site in pUC57 was located 5' of the KpnI site in the primer was selected. The 5' fragment was then excised with Eco147I and ligated into pUC57-1a-3' linearized with Eco147I. The complete TGA1a sequence (1136 bp) was excised with Acc65I / BamHI from pUC57-1a-5'3' and inserted for creating an in-frame fusion with GFP into the pHBT-L-GFP plasmid opened with the same restriction enzymes.

\subsubsection{6. $p H B T-T e t R-G F P$}

To estimate whether the size of the fusion proteins might influence their targeting, a fusion was constructed between the bacterial tetracycline repressor (TetR, a nontargeted $24 \mathrm{kDa}$ DNA-binding protein with no known function in plants) and GFP. For this purpose the TetR coding sequence was excised from pUC-TetR-VP16 as a $653 \mathrm{bp} \mathrm{Acc65I} \mathrm{/} \mathrm{BsiWI} \mathrm{fragment} \mathrm{and} \mathrm{inserted} \mathrm{into} \mathrm{the} \mathrm{pHBT-L-GFP} \mathrm{vector} \mathrm{which} \mathrm{was}$ linearized with Acc65I (the screening for the correct direction of the insert was dome by looking for a reconstituted Acc65I site in the beginning of the TetR gene).

\subsubsection{7. $p G F P-T G A 2.1$}

To create an N-terminal fusion of TGA2.1 with mGFP4, controlled by the $35 \mathrm{~S}$ promoter, the coding sequence of TGA2.1 was excised as an EcoRI -fragment from pGBT2.1 and inserted in the necessary orientation into the pUC19-GFP vector, linearized with EcoRI and de-phosphorilated for reducing its self-ligation.

\subsubsection{8. $p G F P-T G A 2.2$}

To create an N-terminal fusion of TGA2.2 with mGFP4 under the control of the 35S promoter, the coding sequence of TGA2.2 was excised as an EcoRI / BamHI fragment from pGAD2.2 and inserted into the pUC19-GFP vector, opened with the same enzymes. 


\subsubsection{9. $p C H S-G F P-T G A 2.2 C-L e u M u t$}

The coding sequence for the $185 \mathrm{C}$-terminal amino acids of TGA2.2 with two leucine-to-glycine exchanges in the putative nuclear export (NES) pattern was amplified by PCR with primers designed with artificial restriction sites TGA2.2CLeuMut For (EcoRI) and Rev (BamHI); ligated in the pGEM®-T cloning vector (Promega) and transferred in the pUC19-CHS-GFP vector as an EcoRI / Bam HI fragment.

\subsubsection{Transient expression of fusion proteins in N. tabacum protoplasts}

\subsubsection{Preparation of mesophyl protoplasts from N. tabacum}

Leaves from tobacco plants (SNN cultivar) grown in sterile conditions were cut with a scalpel on the lower surface every $1-2 \mathrm{~mm}$, the midrib was removed and the two halves of the leaf were transferred with the cut side downwards into Petri dishes with $7 \mathrm{ml} 1 \mathrm{x}$ digestion mix. The plates were incubated overnight at $24^{\circ} \mathrm{C}$ in darkness. The next day the dishes were gently shaken to release the protoplasts from the cuticle, incubated for another $30 \mathrm{~min}$, then poured on a $100 \mu \mathrm{m}$ filter and filtered through it and centrifuged in $50 \mathrm{ml}$ tubes for $20 \mathrm{~min}$ at $60 \mathrm{x}$ g at room temperature in a swingout rotor. Living protoplasts formed a green layer on the surface of the solution, whereas cell debris stayed underneath. With a sterile Pasteur pipette attached to a peristaltic pump the underlying solution and pellet were removed, all the protoplasts were resuspended immediately in $25 \mathrm{ml}$ of electroporation buffer, centrifuged at $100 \mathrm{x}$ $\mathrm{g}$ for $10 \mathrm{~min}$ and the lower phase was removed again; this washing step was performed twice more (centrifugation at $100 \mathrm{x} \mathrm{g}$ for $5 \mathrm{~min}$ ) until clearing of the underlying solution. The protoplasts from different tubes were combined and counted, resuspended in an appropriate vlume of electroporation buffer in order to obtain a concentration of $2-5 \times 10^{6}$ protoplasts per $\mathrm{ml}$, and used as soon as possible for electroporation.

\subsubsection{Electroporation of mesophyl protoplasts}

$500 \mu 1$ of mesophyl protoplasts were pipetted slowly and gently into an electroporation cuvette (rinsed with ethanol), 10-30 $\mu \mathrm{g}$ of plasmid DNA in $100 \mu \mathrm{l}$ of electroporation buffer were added, mixed by gentle shaking and incubated for $5 \mathrm{~min}$. The electroporation was performed at $160 \mathrm{~V}$ and $910 \mu \mathrm{F}$ and the protoplasts were left for recovery from the electroshock for $30 \mathrm{~min}$ without shaking or vibrations. After this incubation the cuvettes were washed twice with $1 \mathrm{ml}$ TEX buffer and the obtained cell suspensions were incubated in small Petri dishes overnight at $24^{\circ} \mathrm{C}$ in darkness for the expression of the transfected proteins. The visualization of the different fusions between TGA factors and GFP was done with fluorescence or confocal laserscanning microscopy.

\subsubsection{Preparation of protoplasts from BY-2 tobacco suspension cells}

BY-2 cells can be used for protoplast preparation three days after sub-cultivation. 20 $\mathrm{ml}$ of suspension culture were pelleted for $5 \mathrm{~min}$ at $400 \mathrm{x} \mathrm{g}$ (all following 
centrifugation steps with soft start and at room temperature), washed with $25 \mathrm{ml}$ of wall-digestion solution (without enzymes), collected again and resuspended in 45-50 $\mathrm{ml}$ of wall-digestion solution. This suspension was dispensed in 4 Petri dishes which were sealed with Parafilm ${ }^{\mathrm{TM}}$ and incubated at $24^{\circ} \mathrm{C}$ overnight in darkness without shaking. The protoplasts from each plate were collected separately in $50 \mathrm{ml}$ tubes by a centrifugation at $100 \mathrm{x}$ g for $5 \mathrm{~min}$, the supernatant was not removed completely and the protoplasts were resuspended in the rest of it. $20 \mathrm{ml}$ of wall-digestion solution (without enzymes) were added for washing; the protoplasts were pelleted $(100 \mathrm{x} \mathrm{g}, 5$ min) and resuspended again in the rest of the supernatant. $10 \mathrm{ml}$ of W5 solution were added slowly $(1,2,3,4 \mathrm{ml})$, the solutions were mixed gently, the protoplasts were collected and resuspended in the rest of the supernatant. $5 \mathrm{ml}$ of W5 were added and 2 $\mu \mathrm{l}$ aliquots were taken for protoplast counting; meanwhile the protoplasts were incubated for $45 \mathrm{~min}$ at $4^{\circ} \mathrm{C}$ in darkness. Then the W5 solution was removed completely (100 x g, $5 \mathrm{~min})$ and the pellet was resuspended in an appropriate volume of MMM solution to a density of $2 \times 10^{6}$ protoplasts per $\mathrm{ml}$.

\subsubsection{PEG-mediated transfection of BY-2 protoplasts}

$300 \mu \mathrm{l}$ of the protoplast suspension were transferred with a clipped blue tip into redcap tubes where the plasmid DNA (in a maximal volume of $30 \mu$ ) was added in advance. The solutions were mixed carefully, $300 \mu \mathrm{l}$ of PEG solution were added drop-wise, mixed gently and the samples were incubated for $20 \mathrm{~min}$ (from the $1^{\text {st }}$ sample) at room temperature. $10 \mathrm{ml}$ of $\mathrm{W} 5$ solution were added gradually (1, 2, 3, 4 $\mathrm{ml}$ ) and mixed between the steps very carefully. The protoplasts were collected, the supernatant was removed and the pellet was resuspended in $700(200+500) \mu \mathrm{l}$ of MSsucrose medium. The samples were incubated overnight at $24^{\circ} \mathrm{C}$ in darkness (tubes tilted and caps loose) and screened for GFP fluorescence on the next day.

\subsubsection{Stable transformation of Nicotiana tabacum}

The binary vectors used for the transfer and integration of the TGA-GFP fusion proteins expression cassettes into the tobacco genome were all based on pBin19; all insertions were done as "blunt / sticky" ligations, after which only the EcoRI site was reconstituted.

\subsubsection{1.pBin-HBT-2.1-GFP}

The DNA sequence of the HBT::TGA2.1-GFP::nos expression cassette was cut out from the pHBT-2.1-GFP plasmid as an EheI / EcoRI fragment (3156 bp), purified from a gel and inserted into the T-DNA segment of pBin19, opened with SmaI / EcoRI.

\subsubsection{2. pBin-HBT-2.2-GFP}

The HBT::TGA2.2-GFP::nos DNA region was excised from pHBT-2.2-GFP with EheI / EcoRI as a $2763 \mathrm{bp}$ fragment, recovered from a gel and ligated in the T-DNA of pBin19, cut with SmaI / EcoRI. 


\subsubsection{3. pBin-HBT-1a-GFP}

Due to a second EcoRI recognition site in the beginning of the coding sequence for TGA1a-GFP, a partial digestion of the pHBT-1a-GFP plasmid with Ehe I EcoRI was performed, the fragment with the right size of $2891 \mathrm{bp}$ (HBT::TGA1a-GFP::nos) was gel-purified and ligated into the SmaI / EcoRI -opened pBin19.

\subsubsection{4. pBin-HBT-TetR-GFP}

An EheI / EcoRI fragment of 2436 bp (HBT::TetR-GFP:nos) was cut out from pHBT-TetR-GFP, excised and purified from a gel and inserted in the T-DNA part of pBin19, digested with SmaI / EcoRI.

\subsubsection{Stable transformation of Nicotiana tabacum}

For stable transformation of tobacco we modified a naturally existing system for gene transfer between the bacterial and the plant kingdom. Agrobacterium species are able to infiltrate fresh plant wounds and to induce the formation of tumor-like tissues by transferring a part (called "T-DNA") of their "tumor-inducing" (Ti) plasmids into the plant cells with the help of virulence proteins from the vir-region of the Ti-plasmid. If the tumor-inducing genes between the two palindrome borders which define the $\mathrm{T}$ DNA are replaced with foreign genes, tumors are no longer formed and the foreign genes are integrated into the plant genome. The binary vector system we used (described by Hoekema et al., 1983) consists of a modified Ti-plasmid carrying a TDNA with the genes of interest and an antibiotic-resistance gene for selection (in this work the nptII gene for Kanamycin resistance), origins for replication in E. coli and A. tumefaciens but without a vir-region, and a helper Ti-plasmid with the vir-region but without T-DNA; both plasmids had to be present at the same time in the cells of $A$. tumefaciens for the package and transfer of the T-DNA to take place.

The transfer and the stable integration of the TGA-GFP expression cassettes in the genome of tobacco was performed via Agrobacterium tumefaciens-mediated gene transfer, using a modification of the "leaf discs" method of Horsch et al., 1985. Agrobacterium strains carrying binary plasmids with the desired constructs were grown overnight at $28^{\circ} \mathrm{C}$ in $20 \mathrm{ml}$ of YEB medium with antibiotics; $15 \mathrm{ml}$ of the suspension were centrifuged at $3000 \mathrm{rpm}$ (Eppendorf), the bacterial pellets were resuspended in the same volume of fresh YEB medium and transferred into Petri dishes. Leaf discs (approx. $1 \mathrm{~cm}^{2}$ ) from tobacco plants grown in sterile conditions were dipped in the Agrobacterium suspensions for 2-3 min, rinsed 3 times in a battery of Petri dishes with sterilized tap water and placed on solid 2MS medium plates with the lower surface downwards. Those plates were incubated for 2 days in darkness at $24^{\circ} \mathrm{C}$; during this co-cultivation the bacterial cells could infiltrate inside the leaf tissues and transfer the T-DNAs carrying the coding sequences of the fusion proteins into the plant cells and subsequently to the nuclei, where after recombination events the foreign DNA was stably integrated into the plant genome. After this incubation the leaf discs were transferred on plates with shoot-induction (SHI) medium and incubated at $24^{\circ} \mathrm{C}$ and a light : darkness cycle of $16: 8$ hours for several weeks (plates were refreshed every week), during which the formation of callus tissue was induced 
due to the hormones in the medium (BAP and NAA). When new shoots were generated from the calli, they were transferred for the formation of roots on $2 \mathrm{MS}$ solid medium containing Cefotaxim (selective against Agrobacterium tumefaciens) and an antibiotic (in this work Kanamycin) for the selection of the transgenic shoots.

\subsubsection{Induction of gene expression in Nicotiana tabacum}

For studying the salicylic acid (SA) or auxin $(2,4-\mathrm{D})$-inducible gene expression in leaves, tobacco plants were grown in hydroponics or in soil for 6-8 weeks; only plants without visible signs of senescence and any flowers buds were used for experiments. Leaf discs $(\mathrm{d}=3 \mathrm{~cm})$ from the upper leaves of the plants were floated on $100 \mathrm{ml}$ of 20 $\mathrm{mM}$ potassium phosphate buffer $\mathrm{pH} 5.8$ and incubated in a climate chamber at $24^{\circ} \mathrm{C}$. The inductions were performed with $1 \mathrm{mM} \mathrm{SA}$ or $50 \mu \mathrm{M} 2,4-\mathrm{D}$. The samples were collected at certain time-points (3-4 discs for each time-point), flash-frozen in $\mathrm{N}_{2}$ and stored at $-80^{\circ} \mathrm{C}$ until preparation of RNA.

\subsubsection{Infiltration of Nicotiana tabacum leaf discs with Leptomycin B (LMB)}

Leaf discs $(\mathrm{d}=3 \mathrm{~cm})$ were dipped in $20 \mathrm{mM}$ potassium phosphate buffer $\mathrm{pH} 5.8$ containing $2 \mu \mathrm{M}$ Leptomycin B (a specific inhibitor of XPO1-mediated nuclear export) and gently pressed to the bottom of a small Petri dish with a thin metal grid so that all leaf surface was under buffer. The samples were then subjected to vacuum until all the air from the intercellular cavities in the leaf had been removed as bubbles and replaced with buffer. SA was added in different time-points, samples were incubated for $1 \frac{1}{2}$ hours, flash-frozen in liquid $\mathrm{N}_{2}$ and processed further for RNA preparation.

\subsection{Northern blotting}

\subsubsection{Radioactive labeling of DNA probes for hybridization}

DNA fragments for radioactively- labeled probes were cut out by restriction digestion (3.2.1.5) of the plasmids (2.5.1.5.) and purified from agarose gel slices (3.2.2.3.). The labeling was performed according to the "fandom-prime" method of Feinberg and Vogelstein (1983), in which randomized hexa-nucleotides bind on the denatured single-stranded DNA fragment and serve as primers for the de novo synthesis of a complementary chain with the incorporation of radioactively-labeled nucleotides. The reaction is catalyzed by the Klenow fragment of $E$. coli DNA polymerase I, lacking the 3'? 5'exonuclease activity (exo'). In a volume of $33 \mu \mathrm{l} 40-50 \mathrm{ng}$ of purified DNA fragment and $1.4 \mu \mathrm{l}$ of Random Primers (Invitrogen) were mixed, denatured at $95^{\circ} \mathrm{C}$ for $5 \mathrm{~min}$ and allowed to cool down at room temperature. To the reaction were added $5 \mu 1$ of $10 \mathrm{x}$ Klenow buffer (MBI Fermentas) and $6 \mu \mathrm{l}$ dNTP-A mix (dCTP, dGTP, dTTP, $500 \mu \mathrm{M}$ each). In the isotope laboratory $5 \mu \mathrm{l}$ of $\left[\mathrm{a}^{32} \mathrm{P}\right]$-dATP $(800 \mathrm{Ci} / \mathrm{mmol})$ and 1 Unit of Klenow exo ${ }^{-}$were added up to a total of $50 \mu$, then the sample was vortexed gently and incubated for 2 hours at $37^{\circ} \mathrm{C}$. The reaction was stopped by the addition of $50 \mu \mathrm{l}$ STE buffer and the DNA fragments were precipitated by adding 250 $\mu 196 \%$ (v/v) ethanol overnight at $-20^{\circ} \mathrm{C}$. After a centrifugation $(13000 \mathrm{rpm}, 30 \mathrm{~min}$, 
Biofuge pico) the non-incorporated nucleotides were removed with the supernatant, the pellet was resuspended in $100 \mu \mathrm{TE}$ buffer and stored at $-20^{\circ} \mathrm{C}$.

\subsubsection{Transfer of RNA onto nylon membranes}

Total RNAs in equalized amounts were separated on denaturing formaldehyde agarose gels as described previously (3.2.2.2.). After the electrophoresis the RNAs were transferred onto nylon membranes (Hybond $\mathrm{N}^{+}$, Amersham) by capillary blotting. In a plastic tray filled with 1 liter of $10 \mathrm{x}$ SSC buffer a flat-surface plastic stand was fixed above the buffer level and covered (avoiding air bubbles) with: two pre-wet in $10 \times$ SSC layers of $30 \times 15 \mathrm{~cm}^{2} 3 \mathrm{MM}$ paper stripes with their ends dipped in the buffer underneath; the $10 \times 15 \mathrm{~cm}^{2}$ RNA gel with the upper side downwards and surrounded by foil stripes to prevent drying-out of the papers; the $10 \times 15 \mathrm{~cm}^{2}$ Hybond $\mathrm{N}^{+}$membrane pre-wet in $10 \mathrm{x}$ SSC; 3 layers of pre-wet $3 \mathrm{MM}$ papers the size of the gel and the membrane; approx. $10 \mathrm{~cm}$ thick layer of paper towels; a equally distributed weight of approx. $1 \mathrm{~kg}$ (thick catalogue, etc.). After at least 14 hours of blotting, the construction was dismantled and the transfer of RNA on the nylon membrane was controlled under UV light and photographed. The covalent binding of the RNA molecules to the membrane surface was performed by incubation at $80^{\circ} \mathrm{C}$ for 2 hours.

\subsubsection{Hybridization of Northern blots}

The membrane was placed with the RNA-bound sides inwards in a hybridization glass tube and pre-hybridized at $65^{\circ} \mathrm{C}$ in $10 \mathrm{ml}$ of Church solution $(250 \mathrm{mM}$ sodium phosphate $\mathrm{pH}$ 7.2, $1 \mathrm{mM}$ EDTA, 7\% (w/v) SDS) without a labeled probe for saturating the free unspecific binding sites on the membrane. After an hour of incubation the Church solution was discarded. The radioactively labeled probe (see labeling) was dissolved in $10 \mathrm{ml}$ of Church, denatured on a boiling water bath for 10 min, immediately transferred on ice, left there for $5 \mathrm{~min}$ and added to the membrane. The tube was rotated overnight at $65^{\circ} \mathrm{C}$ to allow hybridization of the labeled singlestranded probe with RNAs with complementary sequences. The solution containing the probe was collected and stored at $-20^{\circ} \mathrm{C}$ for multiple usages, and the membrane was subjected to a series of washes with buffers with a decreasing $\%$ of SSC (2\%; 1 $\% ; 0.5 \% ; 0.1 \%$ - each containing $0.1 \%$ SDS) for removing the unspecific-bound probe until the radioactivity of the membrane was under $30 \mathrm{cpm}$; then the membrane was sealed in foil and exposed to an Imager Plate (IP) overnight. The signals were detected with a Bioimager (BAS-1000, Fuji) and processed and quantified with the PCBAS ${ }^{2} 2.09$ and TINA®2.0 programs (Raytest $\mathrm{GmbH}$ ). For no rmalization, signals were compared with the signals from the EtBr-staining of the RNAs.

\subsubsection{Stripping and re-probing of Northern membranes}

Already hybridized probes can be removed from the membrane with 2 times of 30 min washing at $75^{\circ} \mathrm{C}$ on a shaking water bath (The Belly Dancer®, Stovall) with 250 $\mathrm{ml}$ of pre-warmed $0.1 \%(\mathrm{w} / \mathrm{v}) \mathrm{SDS}$, and after a subsequent pre-hybridization membranes can be re-probed with another labeled fragment. 


\subsection{Biochemical methods}

\subsubsection{Raising polyclonal antiserum against the C-termini of TGA2.1 and TGA2.2}

\subsubsection{Plasmids for inducible expression of GST-2.XC constructs}

The C-terminal regions of TGA2.1 (255 a.a.) and TGA2.2 (257 a.a.) were amplified by PCR and sub-cloned first in the pGEM®-T cloning vector (Promega). The primers used for PCR (TGA2.XC-Exp For (BamHI) and TGA2.XC-Exp Rev (EcoRI)) were designed with additional restriction sites for creating in-frame $\mathrm{C}$-terminal fusions with the coding sequence of glutathione-S-transferase (GST) in the pGEX4T-1 vector (Pharmacia). In these series of vectors the GST gene is under the control of the IPTGinducible tac promoter. The PCR products excised as BamHI / EcoRI fragments were transferred from the pGEM vector into the expression vector pGEX4T-1 and the middle parts of the fragments were exchanged as NdeI/Mph1103I fragments with the original ones, in order to decrease the chances of point mutations due to PCR mistakes. The reading frames were confirmed by sequencing and the constructs were transformed into the E. coli expression strain W3110.

\subsubsection{Expression of recombinant GST-2.XC -fusion proteins in E. coli}

Preliminary mini-scale preparations were performed for optimization of the conditions for expression of the fusion proteins. Large scale preparations were done as $500 \mathrm{ml}$ cultures from an overnight $10 \mathrm{ml}$ starter culture. At $\mathrm{OD}_{600}=0.6$ the $500 \mathrm{ml}$ cultures were induced with $1 \mathrm{mM}$ IPTG and incubated for 3 hours at $29^{\circ} \mathrm{C}$, the cells were pelleted at $5000 \mathrm{x}$ g for $15 \mathrm{~min}$ at $4^{\circ} \mathrm{C}$, and pellets were resuspended in $25 \mathrm{ml} 1 \mathrm{x}$ PBS with $1 \mathrm{mM}$ PMSF and $50 \mu \mathrm{M}$ leupeptin. The disruption of the cells was performed with an ultra-sound sonicator on ice, the cell debris were sedimented by centrifugation at $12000 \mathrm{x} \mathrm{g}$ for $20 \mathrm{~min}$ at $4^{\circ} \mathrm{C}$ and the supernatants were used for purification of the GST-2.XC fusion proteins. GST protein alone was also expressed for the purpose of antibody affinity purifications (see 3.3.2.2.) using the same method.

\subsubsection{Purification of GST-fused proteins}

For the purification of the GST-fusion proteins an affinity chromatography on glutathione-coupled Sepharose 4B resin (Pharmacia) was performed according to the manufacturer's instructions. The $E$. coli lysates were mixed with pre-equilibrated $2 \mathrm{ml}$ $50 \%$ glutathione Sepharose slurry and incubated for 1 hour at room temperature with stirring to facilitate the interaction of the GST-2.XC fusion proteins with the glutathione-coupled matrix. Then the resin was sedimented at $500 \mathrm{x} \mathrm{g}$ for $5 \mathrm{~min}$ and washed 3 times with $10 \mathrm{ml} 1 \mathrm{x}$ PBS. The elution of the fusion proteins was performed with $10 \mathrm{mM}$ glutathione in $50 \mathrm{mM}$ Tris- $\mathrm{HCl} \mathrm{pH} 8.0$ (3 times $1 \mathrm{ml}$ per "bed volume" of resin), the fractions were pooled and the protein concentrations estimated. The same procedure was used for purification of GST protein alone 


\subsubsection{Immunization}

Immunization of rabbits was performed by the BioScience company, Goettingen, Germany. Approx. $500 \mu \mathrm{g}$ of GST-2.1C and GST-2.2C were pooled together, mixed with the Freundt adjuvant and injected in rabbits. Immunization was repeated 3 times; sera were collected 2-4 weeks after injections and stored in aliquots at $-80^{\circ} \mathrm{C}$.

\subsubsection{Purification of the anti-2.XC specific antibodies}

\subsubsection{Coating of CNBr-activated Sepharose with antigen}

Before coupling, GST-2.XC fractions (a mixture of $5 \mathrm{mg}$ of each fusion protein per $\mathrm{ml}$ resin) were dialyzed overnight at $4^{\circ} \mathrm{C}$ against coupling buffer $\left(0.1 \mathrm{M} \mathrm{NaHCO}_{3} \mathrm{pH}\right.$ $8.3,0.5 \mathrm{M} \mathrm{NaCl}$ ), diluted up to $12 \mathrm{ml}$ with coupling buffer and incubated together with $2 \mathrm{ml}(0.6 \mathrm{~g})$ of pre-activated resin for 2 hours at room temperature. After washing with 5 volumes of coupling buffer the remaining active groups were blocked with $0.1 \mathrm{M}$ Tris- $\mathrm{HCl} \mathrm{pH} 8.0$ at room temperature overnight without stirring. The resin was washed 3 times with $\mathrm{pH}$ change $(10 \mathrm{ml}$ of $0.1 \mathrm{M}$ sodium acetate $\mathrm{pH} 4.0,0.5 \mathrm{M}$ $\mathrm{NaCl} ; 10 \mathrm{ml}$ of $0.1 \mathrm{M}$ Tris- $\mathrm{HCl} \mathrm{pH} 8.0,0.5 \mathrm{M} \mathrm{NaCl}$ ), resuspended in $1 \mathrm{x} \mathrm{PBS}+0.1 \%$ $\mathrm{NaN}_{3}$ and stored at $4{ }^{\circ} \mathrm{C}$. The same procedure was used for coating Sepharose resin with the GST antigen.

\subsubsection{Affinity purification of the anti-2.XC antibodies}

For purification of the anti-2.XC antibodies, the serum from the second bleeding was used. $2 \mathrm{ml}$ of the serum were diluted up to $10 \mathrm{ml}$ with $1 \mathrm{x}$ PBS and centrifuged for 15 $\min$ at $12000 \mathrm{x} \mathrm{g}$ at $4^{\circ} \mathrm{C}$. The cleared supernatant was added to the GST-coupled matrix and incubated for 4 hours at $4{ }^{\circ} \mathrm{C}$ for elimination of the anti-GST specific antibodies. The resin was pelleted; the supernatant was mixed with the GST-2.XCcoupled Sepharose and stirred overnight at $4^{\circ} \mathrm{C}$. After sedimentation, the matrix was washed 5 times with $10 \mathrm{ml}$ of ice-cold 1 x PBS + $0.05 \%$ Tween 20 and twice with 10 $\mathrm{ml}$ of $1 \mathrm{x}$ PBS. The specifically-bound anti-2.XC antibodies were eluted with 4 times $1 \mathrm{ml}$ of $0.1 \mathrm{M}$ Glycine- $\mathrm{HCl} \mathrm{pH} 2.5$ and the elution fractions were neutralized to $\mathrm{pH}$ 7.0 with $30-50 \mu \mathrm{l}$ of $1 \mathrm{M}$ Tris-Base. The eluted antibody solutions were mixed volume to volume with $4 \mathrm{M}\left(\mathrm{NH}_{4}\right)_{2} \mathrm{SO}_{4}$ and incubated overnight at $4^{\circ} \mathrm{C}$, centrifuged for 1 hour at $30000 \mathrm{x} \mathrm{g}$, the pellets were resuspended in $1 \times \mathrm{PBS}+1 \% \mathrm{BSA}$ and stored at $4^{\circ} \mathrm{C}$.

\subsubsection{Preparation of protein extracts from N. tabacum leaves}

\subsubsection{Preparation of nuclei}

All steps of the procedure (modified after Niggeweg (1999) and Prat et al., (1989)) were performed at $4{ }^{\circ} \mathrm{C} .10 \mathrm{~g}$ of frozen in Iquid $\mathrm{N}_{2}$ leaf tissue were grinded to fine powder with a coffee grinder, resuspended in $40 \mathrm{ml}$ of buffer $1 \mathrm{~A}$ and filtered through two layers of Miracloth to separate cell debris from the organelle suspension. The remaining debris and starch granules were remo ved by centrifuging the filtrate at 100 $\mathrm{x} \mathrm{g}$ for $2 \mathrm{~min} 30 \mathrm{sec}(>1000 \mathrm{rpm}$ in Sorvall SS34. The supernatant was transferred 
into new $50 \mathrm{ml}$ tubes and centrifuged at $478 \mathrm{x} \mathrm{g}$ for $5 \mathrm{~min}$ (SS34, $2000 \mathrm{rpm}$ ) to sediment the nuclei. The supernatant from this centrifugation step was discarded; the nuclear pellet was gently resuspended with a paint brush in $8 \mathrm{ml}$ of buffer $0.5 \mathrm{~A}$ and centrifuged for $5 \mathrm{~min}$ at $478 \times \mathrm{g}(2000 \mathrm{rpm})$. This step for the separation of the nuclei from the chloroplasts was repeated three times until there was no green color visible in the nuclear pellet.

\subsubsection{Denatured nuclear protein extracts}

The nuclear pellet from 3.3.3.1 was mixed with 350-450 $\mu \mathrm{l} 4 \mathrm{M}$ urea extraction buffer (pre-heated at $65^{\circ} \mathrm{C}$ ); the solution was vortexed vigorously and incubated on a water bath at $60^{\circ} \mathrm{C}$ for $10 \mathrm{~min}$. High-molecular DNA was fragmented with an ultrasound treatment, the nuclear membranes were sedimented by centrifugation at room temperature for $10 \mathrm{~min}$ at $15000 \mathrm{rpm}$ (Eppendorf 5403) and the supernatant was transferred into new Eppendorf tubes and stored at $-80^{\circ} \mathrm{C}$. Due to the bromphenolblue dye in the extraction buffer which makes colorimetric assays inapplicable, the protein concentrations were normalized via comparison of Coomassie stained protein extracts after separation on SDS-PAGE. The stained gel was scanned and the protein amounts were estimated with the PCBAS ${ }^{\circledR} 2.09$ program.

\subsubsection{Native nuclear protein extracts}

When native nuclear proteins were to be prepared by the method of Kegler, 2001 the nuclear pellet from 3.3.3.1 was resuspended in $4 \mathrm{ml}$ of ice-cold nuclear lysis buffer with protease inhibitors. DNA was fragmented with a glass tissue homogenizer; the volume of the solution was estimated and it was mixed and stirred in a cup at $4{ }^{\circ} \mathrm{C}$ for 1 hour with $1 / 10$ volume of $4 \mathrm{M}\left(\mathrm{NH}_{4}\right)_{2} \mathrm{SO}_{4}$. The mixture was transferred into new 50 $\mathrm{ml}$ tubes and the nuclear membranes were sedimented by centrifugation at $30000 \mathrm{x} \mathrm{g}$ (SS34, $16000 \mathrm{rpm}$ ) for $30 \mathrm{~min}$ at $4^{\circ} \mathrm{C}$. The supernatant was transferred in ultracentrifuge tubes and centrifuged at $150000 \times \mathrm{g}$ (TFT 65.13, $55000 \mathrm{rpm}$ ) for $75 \mathrm{~min}$ at $4^{\circ} \mathrm{C}$ and the supernatant was concentrated on Centricon ${ }^{\circledR} \mathrm{YM}-30$ to a final volume of $50-100 \mu \mathrm{l}$, aliquoted and stored at $-80^{\circ} \mathrm{C}$.

\subsubsection{Native cytosolic protein extracts}

All steps of the procedure (Rieping et al., 1994) are performed at $4^{\circ} \mathrm{C} .5 \mathrm{~g}$ of frozen leaf tissue were grinded to fine powder, resuspended in $20 \mathrm{ml}$ buffer $\mathrm{C}$ and filtered through one layer of Miracloth. Cell debris were removed by centrifugation at $500 \mathrm{x} \mathrm{g}$ $(\mathrm{SS} 34,2500 \mathrm{rpm})$ for $5 \mathrm{~min}$ at $4^{\circ} \mathrm{C}$ and $4 \mathrm{M}\left(\mathrm{NH}_{4}\right)_{2} \mathrm{SO}_{4}$ was added drop-wise to the supernatant to a final concentration of $10 \%(\mathrm{v} / \mathrm{v})$. The mixture was stirred gently at $4^{\circ} \mathrm{C}$ for 1 hour and centrifuged at $30000 \mathrm{x} \mathrm{g}(\mathrm{SS} 34,16000 \mathrm{rpm})$ for $30 \mathrm{~min}$ to remove membrane fractions. The supernatant was precipitated with the addition of $0.37 \mathrm{~g} / \mathrm{ml}$ $\left(\mathrm{NH}_{4}\right)_{2} \mathrm{SO}_{4}$ and mixing at $4^{\circ} \mathrm{C}$ for at least 12 hours (overnight). The next day the mixture was centrifuged for $60 \mathrm{~min}$ at $30000 \mathrm{x} \mathrm{g}(\mathrm{SS} 34,16000 \mathrm{rpm})$. The protein pellet was resuspended in $1 \mathrm{ml}$ of dialysis buffer and dialyzed against 1 liter of buffer overnight at $4{ }^{\circ} \mathrm{C}$ with one buffer change. Extracts were aliquoted, frozen in liquid $\mathrm{N}_{2}$ and stored at $-80^{\circ} \mathrm{C}$. 


\subsubsection{Native total cellular protein extracts (Fix Prot)}

Native total protein extracts were prepared by a procedure described by Kegler, 2001 . Leaf tissue (approx. $300 \mu \mathrm{g}$ ) was frozen and grinded in liquid $\mathrm{N}_{2}$ and transferred into a $2 \mathrm{ml}$ Eppendorf tube. 2 volumes (w/v) of ice-cold Fix Prot extraction buffer were added; the sample was slowly thawed on ice, vortexed for homogenization and centrifuged at $4^{\circ} \mathrm{C}$ for $10 \mathrm{~min}$ at $15000 \mathrm{rpm}$ (Eppendorf 5403) to sediment the insoluble cell components. The supernatant was transferred into a pre-cooled Eppendorf tube and the protein concentration was measured according to Bradford (3.3.3.6). After estimation of the protein amounts the sample was aliquoted, flashfrozen in $\mathrm{N}_{2}$ and stored at $-80^{\circ} \mathrm{C}$.

\subsubsection{Estimation of protein concentration}

The protein concentrations of native extracts were measured by a colorimetric assay according to Bradford, 1976 in which a spectral shift in the absorption maximum (from $465 \mathrm{~nm}$ to $596 \mathrm{~nm}$ ) of the protein-binding dye Coomassie Brilliant Blue G-250 is observed upon binding of the dye to hydrophobic regions in the proteins. Adequate volume of protein extracts was mixed on 96-well microtiter plate with $200 \mu \mathrm{l}$ of 5fold diluted Bradford reagent (Roth), incubated for $5 \mathrm{~min}$ and the optical density of the samples at $595 \mathrm{~nm}$ was measured with a MRX plate reader (Dynex). Protein concentrations were calculated with the help of a standard curve derived from different BSA protein amounts $(1 \mu \mathrm{g}, 4 \mu \mathrm{g}, 8 \mu \mathrm{g})$ on the same plate.

\subsubsection{Methanol precipitation of proteins}

For concentration of very diluted protein extracts a precipitation of proteins with methanol/chloroform was performed according to Wessel and Fluegge, 1984. $400 \mu 1$ methanol and $100 \mu \mathrm{l}$ chloroform were added to $400 \mu \mathrm{l}$ of protein extract, mixed well and the phases were separated by a centrifugation at $10700 \mathrm{rpm}$ (Biofuge pico) for 2 min. The upper watery phase was discarded and the proteins (in the interphase) were precipitated with the addition of $300 \mu \mathrm{l}$ of methanol, subsequent vortexing and centrifugation at $13000 \mathrm{rpm}$ for $3 \mathrm{~min}$. The pellet was dried for $15 \mathrm{~min}$ at room temperature, resuspended in $30 \mu$ protein sample buffer, denatured for $10 \mathrm{~min}$ at $65^{\circ} \mathrm{C}$, cooled on ice and used for SDS-PAGE.

\subsubsection{Denaturing SDS-polyacrylamide gel electrophoresis (SDS-PAGE)}

The separation of proteins was performed in denaturing conditions onto discontinuous polyacrylamide gels (consisting of a stacking gel and a resolving gel) after Laemmli, 1970. Resolving gels contained $10 \%$ (w/v) acrylamide/bisacrylamide (19:1), 400 $\mathrm{mM}$ Tris- $\mathrm{HCl} \mathrm{pH} 8.8,0.1 \%(\mathrm{w} / \mathrm{v})$ SDS, $0.1 \%(\mathrm{w} / \mathrm{v})$ TEMED and $0.1 \%(\mathrm{w} / \mathrm{v})$ ammonium persulfate (APS). Stacking gels contained $4 \quad \% \quad(\mathrm{w} / \mathrm{v})$ acrylamide/bisacrylamide (37.5: 1), $125 \mathrm{mM}$ Tris- $\mathrm{HCl} \mathrm{pH}$ 6.8, $0.1 \%$ (w/v) SDS, 0.2 $\%(\mathrm{w} / \mathrm{v})$ TEMED and $0.1 \%(\mathrm{w} / \mathrm{v})$ APS. The protein samples in $4 \mathrm{M}$ urea buffer were denatured for $10 \mathrm{~min}$ at $65^{\circ} \mathrm{C}$ and cooled on ice before loading on the gel. The electrophoresis was performed at $140 \mathrm{~V}$ in $1 \mathrm{x}$ SDS-PAGE running buffer until the bromphenolblue band had run out of the gel (approx. 2 hours). 5-7 $\mu$ l of BenchMark $^{\mathrm{TM}}$ prestained protein ladder was loaded on each gel for estimation of the size of the separated proteins. 


\subsubsection{Coomassie staining of proteins separated on SDS-PAGE}

Denaturing SDS-polyacrylamide gels can be stained for the detection of proteins with the Coomassie Brilliant Blue G-250 dye (Ausubel et al., 1988). The gels were transferred into plastic containers and fixed with $25 \%(\mathrm{v} / \mathrm{v})$ iso-propanol in $10 \%$ $(\mathrm{v} / \mathrm{v})$ acetic acid for $30 \mathrm{~min}$ on a shaker, the fixing solution was removed, the staining solution (0.006 \% (w/v) Coomassie dye (BioRad) in $10 \%(\mathrm{v} / \mathrm{v})$ acetic acid) was added and the gels were incubated overnight at room temperature on a shaker. The next day the gels were destained in 2 x large volumes of $10 \%$ (v/v) acetic acid, briefly rinsed in deionized $\mathrm{H}_{2} \mathrm{O}$ and scanned.

\subsubsection{Immuno-blotting (Western blot)}

\subsubsection{Semi-dry transfer of proteins onto a PVDF membrane}

The transfer of proteins from the SDS-PAGE gel onto PVDF membranes was performed by a semi-dry blotting procedure (Towbin et al., 1979 with modifications) in an electric field between two graphite plates. The construction of the blotting "sandwich" $\left(18 \times 8 \mathrm{~cm}^{2}\right)$ was as follows (from anode to cathode plate): two layers of Whatman paper pre-wet in transfer buffer, the PVDF membrane pre-activated in methanol and pre-wet in transfer buffer afterwards, the gel, again two layers of prewet Whatman sheets. The bubbles between the sheets were removed by gentle rolling of a glass pipette on the sandwich, the cathode plate was mounted and pressed with a weight of approx. $1 \mathrm{~kg}$ for better contact between all the layers. The transfer was performed with a constant electric current of $140 \mathrm{~mA}$ per gel for 1 hour, the sandwich was disassembled and the PVDF membrane re-activated in methanol for $5 \mathrm{~min}$. The transfer of the proteins was controlled by a transient staining with Ponceau solution.

\subsubsection{Immuno-detection of the proteins with specific antibodies}

The re-activated PVDF membrane was washed 2 x 5 min with 1 x TBS-T (alternatively $1 \mathrm{x}$ PBS-T) and the non-specific protein-binding capacity of the PVDF membrane was saturated by an overnight incubation at $4^{\circ} \mathrm{C}$ in $1 \times \mathrm{TBS}-\mathrm{T}+2 \%(\mathrm{w} / \mathrm{v})$ fatty-acid free BSA (alternatively $5 \%(\mathrm{w} / \mathrm{v})$ non-fat dried milk). The next day the membrane was rinsed for $3 \times 5 \mathrm{~min}$ in $1 \times \mathrm{TBS}-\mathrm{T}$ and the solution with the primary antibody diluted appropriately in $1 \mathrm{x}$ TBS-T $+0.5 \%$ (w/v) BSA (alternatively $2 \%$ (w/v) milk) was added. The membrane was incubated with the primary antibody for 2 hours at room temperature with gentle shaking. Non-bound antibodies were washed away by $4 \mathrm{x}$ min washes with large volumes of $1 \mathrm{x}$ TBS-T. The incubation with the secondary antibody (anti-rabbit IgG- antibody - peroxidase conjugate) diluted usually $1: 10000$ in $1 \mathrm{x}$ TBS-T was performed on a shaker at room temperature for 1 hour, then the membrane was washed 4 x 5 min with 1 x TBS-T and 2 x 5 min with $1 \times$ TBS. The detection of the "protein : primary Ab : secondary Ab-peroxidase" complex was done with the Enhanced Chemiluminescence Plus ${ }^{\mathrm{TM}}$ (ECL+) Kit (Amersham). The membrane was incubated with the enzyme substrate for $5 \mathrm{~min}$ at room temperature and the chemiluminescence was detected by an exposition to a Cronex 10T X-ray film (DuPont) for an optimal time range (from $15 \mathrm{sec}$ to several $\mathrm{min}$ ) according to the strength of the signals. 


\subsubsection{Stripping and re-probing a PVDF membrane}

For multiple detection of the PVDF membranes with different primary antibodies a stripping procedure for the removal of the previously-bound antibodies was performed. The membrane was re-activated in methanol, then stripped for $3 \times 5 \mathrm{~min}$ with $100 \mathrm{mM}$ Glycine $\mathrm{pH} 2.5$, washed 2 x 5 min with large volumes of 1 x TBS-T (1 $\mathrm{x}$ PBS-T); drained as much as possible without drying, blocked again and processed further (see 3.3.6.5)

\subsection{Electrophoretic Mobility Shift Assay (EMSA)}

Electrophoretic mobility shift assay (also known as "gel retardation assay" or "gelshift") provides a simple and rapid method for detecting DNA-protein interactions. This method is used widely in the study of sequence-specific DNAbinding proteins such as transcription factors. The assay is based on the observation that DNA-protein complexes due to their higher molecular weight migrate through a non-denaturing polyacrylamide gel slower than the free DNA-fragments or doublestranded oligonucleotides. The gel shift assay is performed by incubating a purified protein or a mixture of proteins (nuclear or cell extracts, etc.) with a $\left[{ }^{32} \mathrm{P}\right]$ end-labeled DNA fagment containing a binding site(s) for the studied proteins. The eventual interaction complexes are analyzed on non-denaturing polyacrylamide gels and visualized by autoradiography.

\subsubsection{Preparation of a labeled as-1 fragment for EMSA}

The as-1 DNA fragment for gel-retardation assay was labelled by Klenow fill-in (see 3.2.1.6) of the 5'-overhangs with ${ }^{32} \mathrm{P}$-a-ATP. The pUC-as-1-BpiI plasmid containing a cloned $a s-1$ fragment was digested with $B p i I$, the restriction efficiency was checked on a gel and the concentration of the as-1 fragment was determined compared to a DNA standard (1 Kb DNA Ladder). The labelling reaction contained:

$\begin{array}{lrr}\text { plasmid digest }(\sim 3 \mu \mathrm{g}) & \mathrm{X} & \mu \mathrm{l} \\ 10 \mathrm{x} \text { KGB buffer } & 2.0 & \mu 1 \\ \text { Klenow exo- } & 0.8 & \mu 1 \\ {\left[{ }^{32} \mathrm{P}\right] \text {-a-ATP }} & 5.0 & \mu 1 \\ \mathrm{H}_{2} \mathrm{O} & \text { up to } 20 & \mu 1\end{array}$

The labelling reaction was incubated at $37^{\circ} \mathrm{C}$ for 2 hours, then applied on a MicroSpin G25 column (Pharmacia) and centrifuged for $2 \mathrm{~min}$ at $735 \mathrm{x} \mathrm{g} \mathrm{(2600} \mathrm{rpm} \mathrm{in} \mathrm{a} \mathrm{Biofuge}$ Pico, Heraeus) to remove the non-incorporated nucleotides from the reaction. $5 \mu 1$ of BOX dye mix were added to the flow-through fraction and the sample was applied on a non-denaturing 5\% polyacrylamide gel. The gel was run for 2 hours at $180 \mathrm{~V}$, the gel chamber was dismantled and gel was wrapped in foil and exposed to an X-ray film for $10 \mathrm{~min}$. After developing and drying the film, the spot on the film where the radioactively-labelled fragment was detected, was excised with a scalpel and using this X-ray film as a standard, a slice of the gel at the site of the fragment was cut out 
and the gel piece was transferred into a new screw-cup tube. $400 \mu \mathrm{l}$ of TE buffer $\mathrm{pH}$ 8.0 were added, the sample was homogenized as much as possible by pipetting and incubated overnight at $37^{\circ} \mathrm{C}$. The next day the tube was centrifuged at $13000 \mathrm{rpm}$ in a Biofuge Pico for $30 \mathrm{~min}$ to spin down the gel pieces; the supernatant was transferred into a new screw-cup, the radioactive counts were measured and the fragment was stored at $-20^{\circ} \mathrm{C}$ until usage.

\subsubsection{Electrophoretic Mobility Shift Assay (EMSA)}

Gelshifts were performed in non-denaturing conditions to allow the binding of the TGA factors to the labelled as-1 fragment; the components for the preparation of $5 \%$ $(\mathrm{w} / \mathrm{v})$ non-denaturing gels are listed in the following table:

$\begin{array}{lrc}\mathrm{H}_{2} \mathrm{O} & 28 \mathrm{ml} \\ 5 \times \mathrm{TBE} & 10 & \mathrm{ml} \\ 87 \% \text { glycerol } & 5.75 & \mathrm{ml} \\ 40 \% \text { acrylamide } & 6.25 & \mathrm{ml} \\ \text { TEMED } & 20 & \mu 1 \\ 15 \% \text { APS } & 200 & \mu \mathrm{l}\end{array}$

After polymerization the gel was mounted in the electrophoresis chamber and pre-run at $100 \mathrm{~V}$ for $30 \mathrm{~min}$, during which the binding reactions were prepared. The protein samples (3-5 $\mu \mathrm{g}$ of native nuclear protein or $15-20 \mu \mathrm{g}$ cytosolic protein) were mixed with $6 \mu \mathrm{l}$ of $5 \mathrm{x}$ binding buffer, $3 \mu \mathrm{l}$ of $1 \mu \mathrm{g} / \mu \mathrm{l}$ poly-dIdC (a non-specific DNA competitor) in a total volume of $28 \mu \mathrm{l}$ and incubated on ice for $10 \mathrm{~min}$ for the elimination of the non-specific DNA-binding activity in the protein samples. Then 2 $\mu 1$ of the radioactively labelled as- 1 fragment were added and the samples were incubated for at least $10 \mathrm{~min}$ at room temperature. For loading of the binding reactions on the gel, $10 \mu \mathrm{l}$ of loading buffer were added, the pockets of the gel were cleaned, the samples were loaded and the gel was run overnight at $4^{\circ} \mathrm{C}$ at $70 \mathrm{~V}$. On the next day the gel was dried under vacuum at $80^{\circ} \mathrm{C}$ for 2 hours and exposed for radiography to a PhosphoImager plate (IP) overnight.

\subsection{Microscopic methods}

\subsubsection{GFP excitation / emission}

The green fluorescent protein used in this work was with synthetically optimized codon usage for expression in human, maize, Arabidopsis, etc. By this optimization some major restriction sites and the cryptic intron discovered in plants by Haseloff et al., (1997) were removed. Additionally the chromophore (SYG) had been re-designed with a substitution of the serine at the $65^{\text {th }}$ position with threonine (TYG) which resulted in a considerable shift in the spectral excitation peak from UV to blue light, in a faster chromophore formation and increased brightness in plant cells. Those modifications improved a lot the detection of the GFP fluorescence in the highlyautofluorescent at UV illumination plant cells and tissues. 


\subsubsection{Fluorescence Microscopy}

Visualization of GFP fluorescence in transfected protoplasts was done either by fluorescence microscopy or confocal laser-scanning microscopy. Fluorescent microscopy was performed with an Axiovert 35 fluorescent microscope (Zeiss) with filter sets for UV light (excitation filter EF 395-440; beam splitter FT-460; ? -pass filter LP-470) and for blue light (excitation filter EF 450-490; beam splitter FT-510; ? band-pass filter LP-520); water-immersion objectives with up to $40 \mathrm{x}$ magnification were used for observations. $10 \mu \mathrm{l}$ of protoplast suspension were pipetted with a clipped yellow tip on a microscopic slide, covered carefully with a covering glass to avoid mechanical shearing of the protoplasts and mounted on the microscope. Screening for protoplasts expressing the transfected GFP-fusion proteins was performed using the blue filter set on a dark background to minimize photo-damages and bleaching of the chromophore of GFP; photographs were taken with a mounted photo camera at blue, UV and visible light.

\subsubsection{Confocal Laser-Scanning Microscopy (CLSM)}

To obtain pictures with higher resolution, GFP-fluorescent transfected tobacco protoplasts and stably transformed tobacco leaf tissues were visualized by confocal laser-scanning microscopy with a LSM 510 inverted laser-scanning microscope (Zeiss, Germany). Transfected protoplasts were prepared for LSM the same way as for fluorescent microscopy (see 3.9.2). Leaf discs from transgenic N. tabacum plants were floated in $20 \mathrm{mM}$ phosphate buffer $\mathrm{pH} 5.8$ and induced with $1 \mathrm{mM}$ SA when necessary; after an incubation time (ranging from minutes to hours) some of the leaf surface tissues were peeled off with sharp pincers and mounted on microscopic slides. The TGA-GFP fusion proteins were excited by illumination with a blue-wavelength Argon laser $(488 \mathrm{~nm})$ whose light was attenuated by an acusto-optical tunable filter (AOTF) to 20-30 $\mu \mathrm{W}$, reflected by a dichroic mirror (HFT 488) and focused on the sample by a Zeiss C-Apochromat numerical aperture (NA) 1.2 water immersion $40 \mathrm{x}$ objective. Out-of-plane fluorescence is considerably reduced by a $100 \mu \mathrm{m}$ pinhole. The fluorescence emission passed through a 505-550 nm band-pass filter, was detected by an avalanche photodiode (APD) and pseudo-colored pictures were generated with the LSM software (Zeiss).

\subsubsection{Fluorescence Correlations Spectroscopy (FCS)}

Fluorescence correlation spectroscopy measurements were performed on a commercial ConfoCor2 / LSM 510 station (Zeiss, Germany). For FCS studies the tissue samples from leaf discs were prepared the same way as for CLSM with an additional embedding of the tissues in low-melting agarose in order to diminish the mobility of the sample during the scanning. For intracellular FCS, the desired measurement position was chosen on the LSM image, using the automated stage positioning of the ConfoCor2 system. The signals were autocorrelated by the ConfoCor2 software program (Zeiss), evaluating the data by non-linear LevenbergMarquardt least-squares fitting to model equations. 


\section{Results}

\subsection{Construction and transient expression of GFP-tagged TGA factors}

Information about the subcellular localization of TGA transcription factors during the activation of systemic acquired resistance could be helpful to better understand their role in the modulation of gene expression in response to pathogens. In this work, the localization patterns of the following TGA transcription factors were investigated:

TGA2.1 - found in leaves and roots; forms heterodimers with TGA2.2; approx. $10 \%$ of the as-1-binding complex in leaves; strong transcriptional activator in yeast; interacts with NPR1 in an yeast two-hybrid system;

$\checkmark$ TGA2.2 - found in leaves and roots; the main component of the as-1-binding complex in leaves (approx. $80 \%$ ); shows no activation properties in yeast; interacts with NPR1

TGA1a - found in roots but not in leaves; activates transcription in yeast; does not interact with NPR1

TetR (tetracycline repressor) - a bacterial DNA-binding protein without NLS as a non-targeted control

For the observations of the localization of TGA2.1, TGA2.2, TGA1a and TetR in living plant cells these factors were cloned at the $5^{\prime}$ or the 3 ' end of the coding sequence of the green fluorescent protein (GFP), expressed transiently or stable as translational fusions and visualized either by fluorescence microscopy (FM) or confocal laser-scanning microscopy (CLSM). All cloning steps and fusion reading frames were confirmed by sequencing. All derivatives were cloned in high-copy plasmids (pUC18/19 derivatives) and purified plasmid DNA $(30 \mu \mathrm{g})$ was used directly for transfections of protoplasts. For stable transformations of tobacco with TGA-GFP fusions the expression cassettes were inserted into the T-DNA of the pBin19 binary vector and incorporated in the plant genome via Agrobacterium-mediated T-DNA transfer.

\subsubsection{Construction of plasmids for transient expression of $C$-terminal fusion proteins of the TGA transcription factors with GFP under the control of the HBT promoter}

A cassette for transient expression (afterwards used also for stable transformations of tobacco) was constructed by introducing a linker in the BamHI site of the pHBT-GFP (S65T) plasmid (Chui et al., 1996; kindly provided by Dr. W Droege-Laser). This allowed the cloning of TGA2.1, TGA2.2 and TGA1a genes as KpnI/BamHI fragments in front of the GFP (S65T) coding sequence (for cloning details see 3.4.1.2 to 3.4.1.6). The 
expression of the constructs was driven by the "hybrid booster of transcription" (HBT) strong constitutive promoter (Sheen, 1993) - a chimera of the CaMV 35S enhancer (HindIII-35S400bp-HindIII) with the basal promoter of the maize C4PPDK gene (HindIII-TATA-5'UTR-BamHI/NcoI), which contains an universal transcriptional enhancer, boosting 10-80 fold the activity of many promoters in plant cells - maize, barley, Arabidopsis, etc. The polyadenylation signal was provided by the nos terminator, present as NotI/PstI-nos-EcoRI fragment in the pHBT-GFP vector. The fusion proteins are schematically presented on Fig. 4.1:

TGA2.1-GFP

TGA2.2-GFP

TGA1a -GFP

TetR - GIP

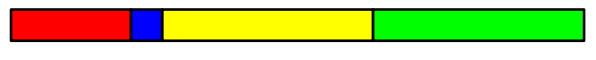

$77.7 \mathrm{kDa}$

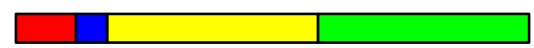

$63.9 \mathrm{kDa}$

$70.0 \mathrm{kDa}$
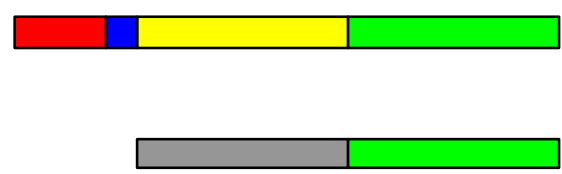

Fig. 4.1. Schematic presentation of the TGA-GFP in-frame fusions

Constructed fusions of TGA factors and TetR with GFP - GFP in green; TGA factors - N-termini in red, bZIP region in blue, C-termini in yellow; TetR protein in grey; calculated molecular weights given in $\mathrm{kDa}$

The reading frames of the constructs were confirmed by sequencing with the GFPII primer; plasmids were amplified in the E. coli DH5a strain and isolated with QIAGEN Midi/Maxi columns. $30 \mu \mathrm{g}$ of plasmid DNA were used for electroporation of mesophyll protoplasts (3.4.2.2). Transfected samples were incubated overnight in darkness at $24^{\circ} \mathrm{C}$ and visualized at $40 \mathrm{x}$ magnification using an Axiovert 35 inverted fluorescent microscope (Zeiss) at blue light $(488 \mathrm{~nm})$, UV light $(395 \mathrm{~nm})$ and white light (see 3.9.2) except for the TetR-GFP Z-series presented here, documented at $488 \mathrm{~nm}$ with a LSM 510 confocal laser-scanning microscope (Zeiss). The results of the localization studies of TGA-GFP fusions in mesophyll protoplasts are presented on Fig. 4.2 - 4.6. The redcolored spots seen on most of the pictures are due to the auto-fluorescent properties of the chloroplast pigments at the above-mentioned wavelengths. The non-fused GFP was evenly distributed between the nucleus and the cytosol (Fig. 4.2), a result of the free diffusion through the nuclear pores due to its low molecular weight (approx. $27 \mathrm{kDa}$ ). The control GFP fusion with the bacterial non-targeted DNA-binding protein TetR (whose molecular weight is close the edge of exclusion size for free diffusion of the nuclear pores) was also present equally in both cellular compartment as seen on Fig. 4.6. As expected for transcription factor derivatives with NLS, all three TGA-GFP fusion proteins were predominantly localized in the nucleus (Fig. 4.3., 4.4., 4.5.) 


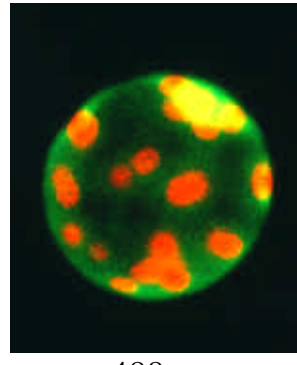

$488 \mathrm{~nm}$

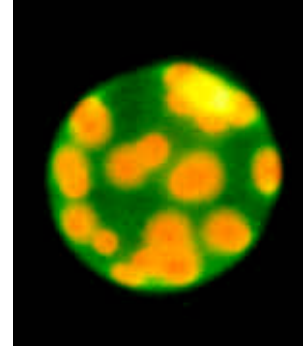

$395 \mathrm{~nm}$

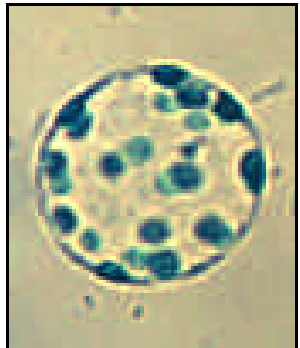

white light

Fig. 4.2. Distribution of a control nonfused GFP5 (pAVA393) in mesophyll protoplasts

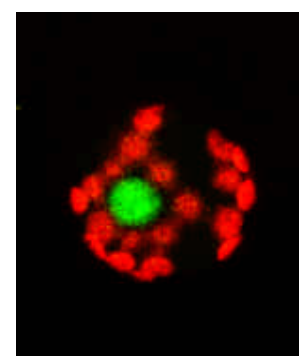

$488 \mathrm{~nm}$

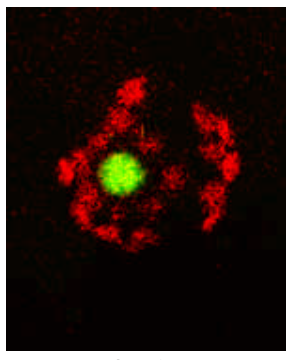

$395 \mathrm{~nm}$

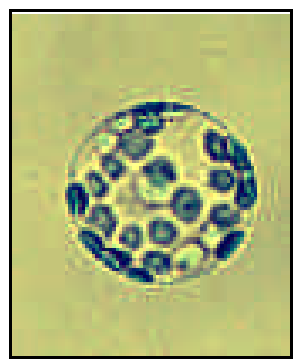

white light

Fig. 4.3. Localization of TGA2.1-GFP fusion protein in mesophyll protoplasts

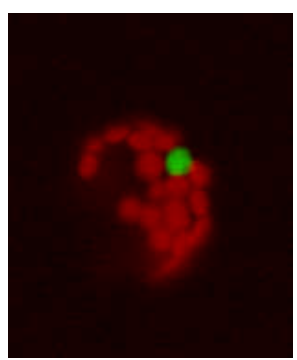

$488 \mathrm{~nm}$

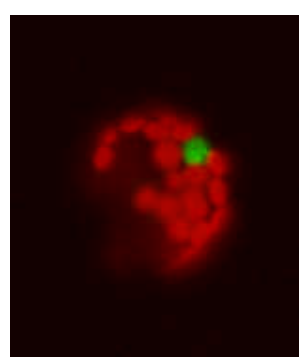

$395 \mathrm{~nm}$

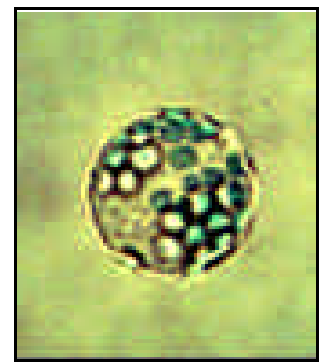

white light

Fig. 4.4. Localization of TGA2.2-GFP fusion protein in mesophyll protoplasts

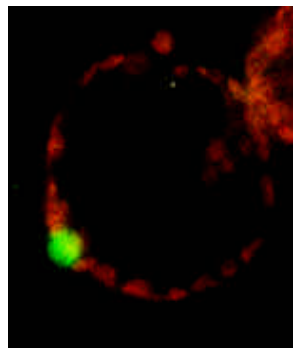

$488 \mathrm{~nm}$

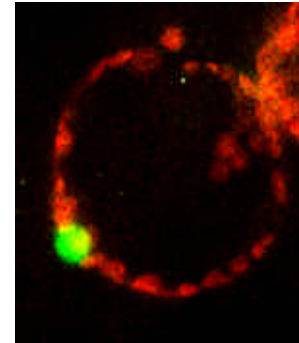

$395 \mathrm{~nm}$

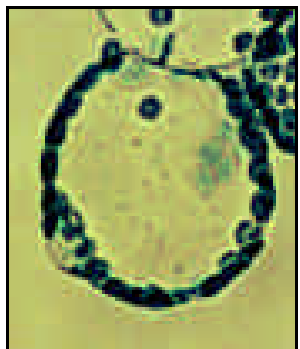

white light

Fig. 4.5. Localization of TGA1aGFP fusion protein in mesophyll protoplasts 

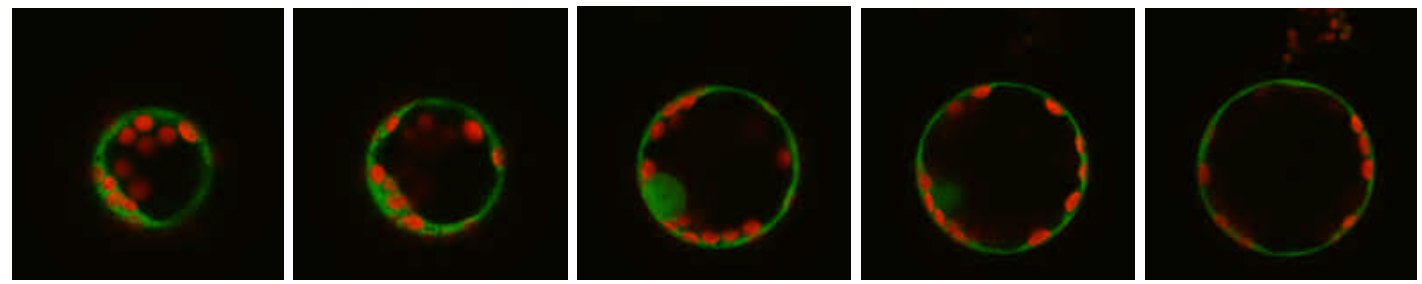

Fig. 4.6. Z-series, showing the localization of TetR-GFP fusion protein in mesophyll protoplasts

The assumption that the cellular compartment in which TGA-GFP fusions are accumulating is the nucleus was proven by adding 2,4-diamidino-2-phenylindole (DAPI, a substance which is intercalating between the DNA strands and fluoresces at UV illumination) to already documented GFP fluorescent protoplast samples on microscopic slides. After $15 \mathrm{~min}$ of incubation during which the DAPI stain infiltrated the protoplasts, the same cells were documented at $395 \mathrm{~nm}$ and results are shown on Fig. 4.7.

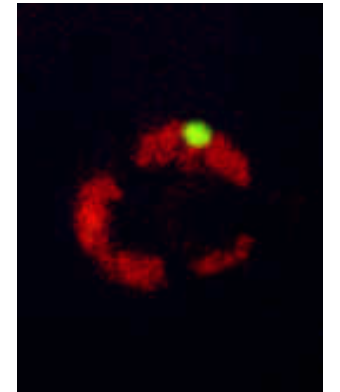

$488 \mathrm{~nm}$ - DAPI

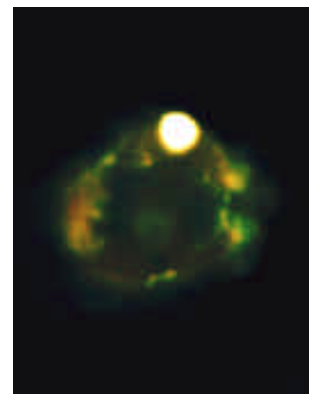

$395 \mathrm{~nm}+$ DAPI TGA2.2-GFP

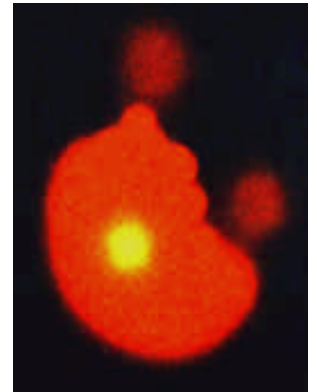

$488 \mathrm{~nm}$ - DAPI TGA1a-GFP

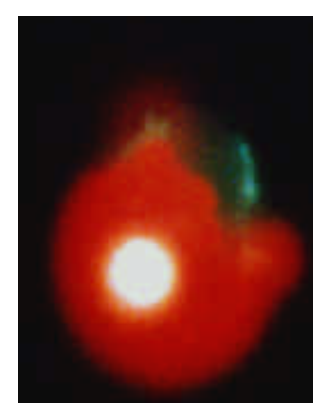

$395 \mathrm{~nm}+\mathrm{DAPI}$

Fig. 4.7. DAPI staining of TGA2.2 -GFP and TGA1a-GFP transfected mesophyll protoplasts

The co-localization of GFP and DAPI fluorescence is clear evidence that TGA-GFP fusion proteins are accumulating in the DNA-most containing compartment of the cell i.e. the nucleus. The yellowish signal shown on the $488 \mathrm{~nm}$ - DAPI picture of TGA1a-GFP was due to an overlapping of the green fluorescence from GFP and the auto-fluorescence from chloroplast pigments.

\subsubsection{Construction of plasmids for transient expression of $N$-terminal fusion proteins of} the TGA transcription factors with GFP under the control of the CaMV $35 S$ promoter

Preliminary data from electrophoretic mobility shift assays suggested a significant amount of as-1 binding activity to be in the cytosol. As long as no GFP fluorescence of TGA-GFP origin was detected in the cytoplasm in the experiments described in 4.1.2., the possibility that the GFP tag at the Cterminus disturbs in some way the natural subcellular targeting of the TGA factors by masking an eventual targeting signal at the Cterminus (see 4.1.3) had to be ruled out. For the purpose we have cloned two full-length 
TGA factors (TGA2.1 and TGA2.2) in the pUC19-GFP vector (kindly provided by Dr. Thomas Merkle) in-frame behind an mGFP4 (S65T) coding sequence and under the control of the CaMV $35 \mathrm{~S}$ constitutive promoter. The constructs are presented schematically on Fig. 4.8.; for cloning details see 3.4.1.7 and 3.4.1.8.

GPP-TGA2.1

GFP·TGA2.2

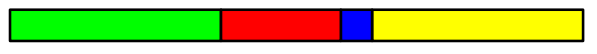

$77.7 \mathrm{kDa}$

$63.9 \mathrm{kDs}$

Fig. 4.8. Schematic presentation of the GFP-TGA in-frame fusions

Constructed fusions of GFP with TGA2.1 and TGA2.2 - GFP in green; TGA factors - N-termini in red, bZIP region in blue, C-termini in yellow; calculated molecular weights given in $\mathrm{kDa}$

After verifying the reading frames of the constructs by sequencing with the mGFP4 forward primer, $30 \mu \mathrm{g}$ of plasmid DNA carrying GFP-TGA constructs were introduced in BY-2 protoplasts via a PEG-mediated transfection procedure (3.4.2.4), samples were incubated overnight at $24^{\circ} \mathrm{C}$ in darkness for expression of the fision proteins and the GFP fluorescence was detected on the next day by confocal laser-scanning microscopy (Fig. 4.9).

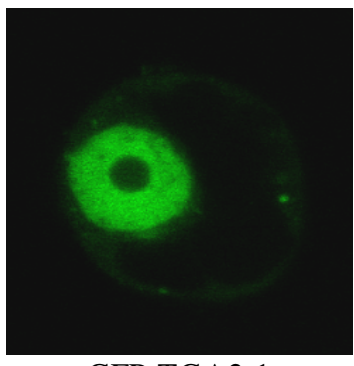

GFP-TGA2.1

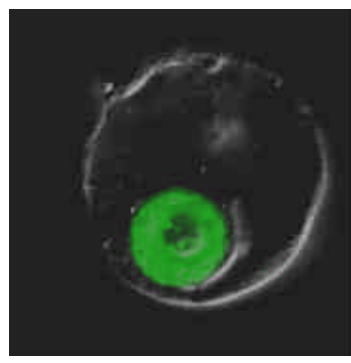

GFP-TGA2.2

Fig. 4.9. Localization of GFP - TGA fusion proteins in BY-2 protoplasts

As seen on Fig. 4.9 the N-terminal GFP fusions of the full-length TGA2.1 and TGA2.2 are accumulating in the nucleus (excluding the nucleolus) similar to the behavior of TGA-GFP fusion proteins (4.1.1, Fig. 4.3 to 5.5) i.e. the position of the GFP protein tag at the $\mathrm{N}$ - or at the C-terminus does not seem to affect a lot the prevailing tendency for nuclear localization of TGA transcription factors due to their NLSs in the bZIP region.

\subsubsection{Construction of GFP fusions with $N$-or C-terminal domains of TGA factors}

As already shown and expected, the predominant localization tendency for the TGA factors is nuclear accumulation in accordance with their biological function involvement in the regulation of pathogen-induced transcription of genes; their subcellular targeting is determined by an NLS of basic amino acids in the bZIP region. 
Besides a NLS, TGA transcription factors have a conserved leucine-rich region in their extreme C-terminus with spacing between the residues $\mathrm{L}-\mathrm{xx}-\mathrm{L}-\mathrm{xx}-\mathrm{L}-\mathrm{x}-\mathrm{L}$ similar to already known nuclear export sequences e.g. the NES of the HIV-1 Rev protein (Fig. 4.10). This NES is a classical example for an NES that is directly recognized by the nuclear export receptor XPO1/CRM1 in a RanGTP-dependent manner, when the Rev protein is bound to viral mRNA transcripts, and as a result the XPO1-RanGTP-RevmRNA complex is exported from the nucleus and dissociates in the cytosol upon hydrolysis of GTP to GDP.

$\begin{array}{rrr}\text { AHBP1b } & (312) & \text { DYFSRLRALSSLWLARPR } \\ \text { OBF4 } & (344) & \text { EYFQRLRALSSSWAARQR } \\ \text { OBF5 } & (306) & \text { NYTLRLRALSSLWLARPR } \\ \text { Perianthia } & (433) & \text { DYISRLRALSSLWLARPR } \\ \text { TGA1 } & (347) & \text { EYFQRLRALSSSWATRHR } \\ \text { TGA3 } & (364) & \text { EYFHRLRALSSLWAARPR } \\ \text { TGA6 } & (307) & \text { DYSSRLRALSSLWLARPR } \\ \text { N.t. PG13 } & (352) & \text { EYFKRLRALSSLWTSRTS } \\ \text { N.t. TGA2.1 } & (435) & \text { EYFSRLRALSSLWLARPR } \\ \text { N. t. TGA2.2 } & (307) & \text { DYFSRLRALSSLWLARPR } \\ \text { N. t. TGA1a } & (407) & \text { EYFERLRVLSSQWATRLR } \\ \text { N.t. TGA7 } & (487) & \text { EYFHRLRALSSLWHARPR } \\ \text { Consensus } & \mathbf{( 4 9 0 )} & \text { EYF RLRALSSLWLARPR } \\ \text { HIV-1 Rev } & \mathbf{( 0 7 5 )} & \text { LQLPPLERLTLD }\end{array}$

Fig. 4.10. Alignment of the C-termini of TGA factors from A. thaliana and N. tabacum Conserved leucines given in red, consensus sequence and the NES of HIV-1 Rev protein bold

The relative accessibility of the putative NES in TGA factors could be a way of controlling the nucleo-cytosolic distribution of TGA factors, hence their involvement in transcriptional events. The domains of bZIP transcription factors seem to be independent in folding (O'Shea et al., 1991; Ellenberger et al., 1992), therefore to overrule the leading role of the nuclear localization signal the NLS and the putative NES were expressed separately by creating various constructs of $\mathrm{N}$ or $\mathrm{C}$ - terminal domains of the TGA factors fused to a CHS-GFP fusion reporter (Fig. 4.11).

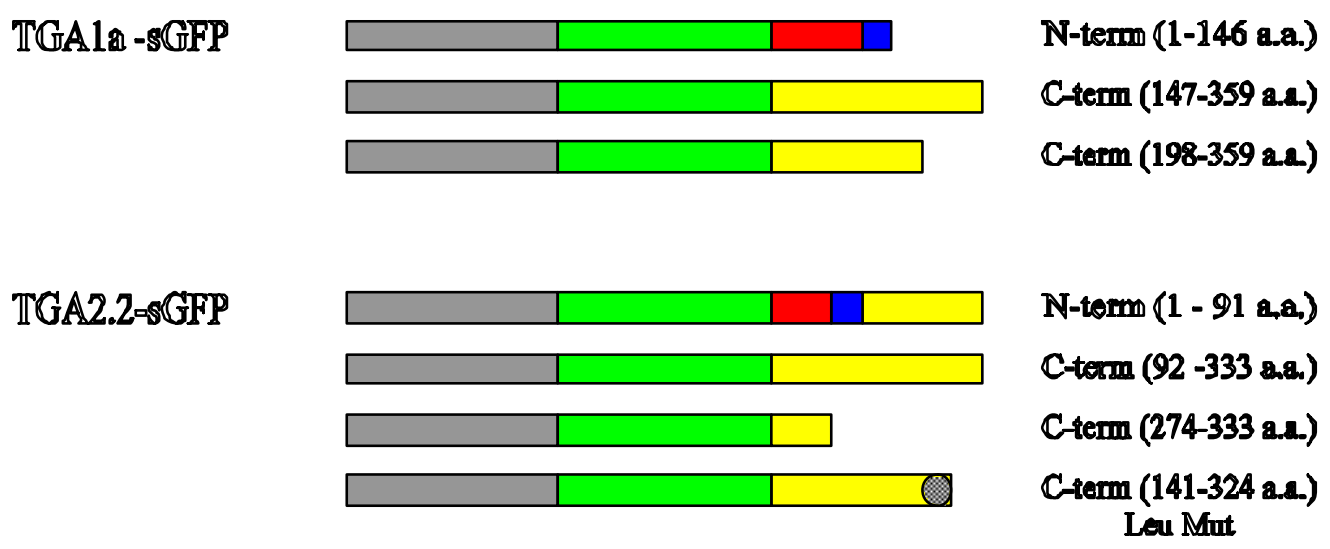

Fig. 4.11. Schematic presentation of the different domain fusions with CHS-GFP

Constructed fusions of domains of TGA factors with CHS-GFP - CHS in grey, GFP in green; TGA factors - N-termini in red, bZIP region in blue, C-termini in yellow, Leu mutations represented with a circle 
For localization studies separate domains were cloned in pUC19-CHS-GFP, fused inframe to the C-terminus of a fusion protein of $72.3 \mathrm{kDa}$ between chalcone synthase (CHS) and GFP. The cloning vector and most of the constructs were generated by Dr. Thomas Merkle (Dept. of Cell Biology, Institute of Biology II, Freiburg University, Germany) except for pCHS-GFP-TGA2.2C-LeuMut (3.4.1.9) in which the C-terminus of TGA2.2 was modified by PCR with primers coding for substitutions of 2 amino acids (Leu315Gly and Leu318Gly), which disrupt the leucine pattern of the putative NES. All constructs were expressed transiently in BY-2 protoplasts via PEG-mediated transfection, the GFP fluorescence was excited by illumination at $488 \mathrm{~nm}$ and was visualized by CLSM (Fig. 4.12).
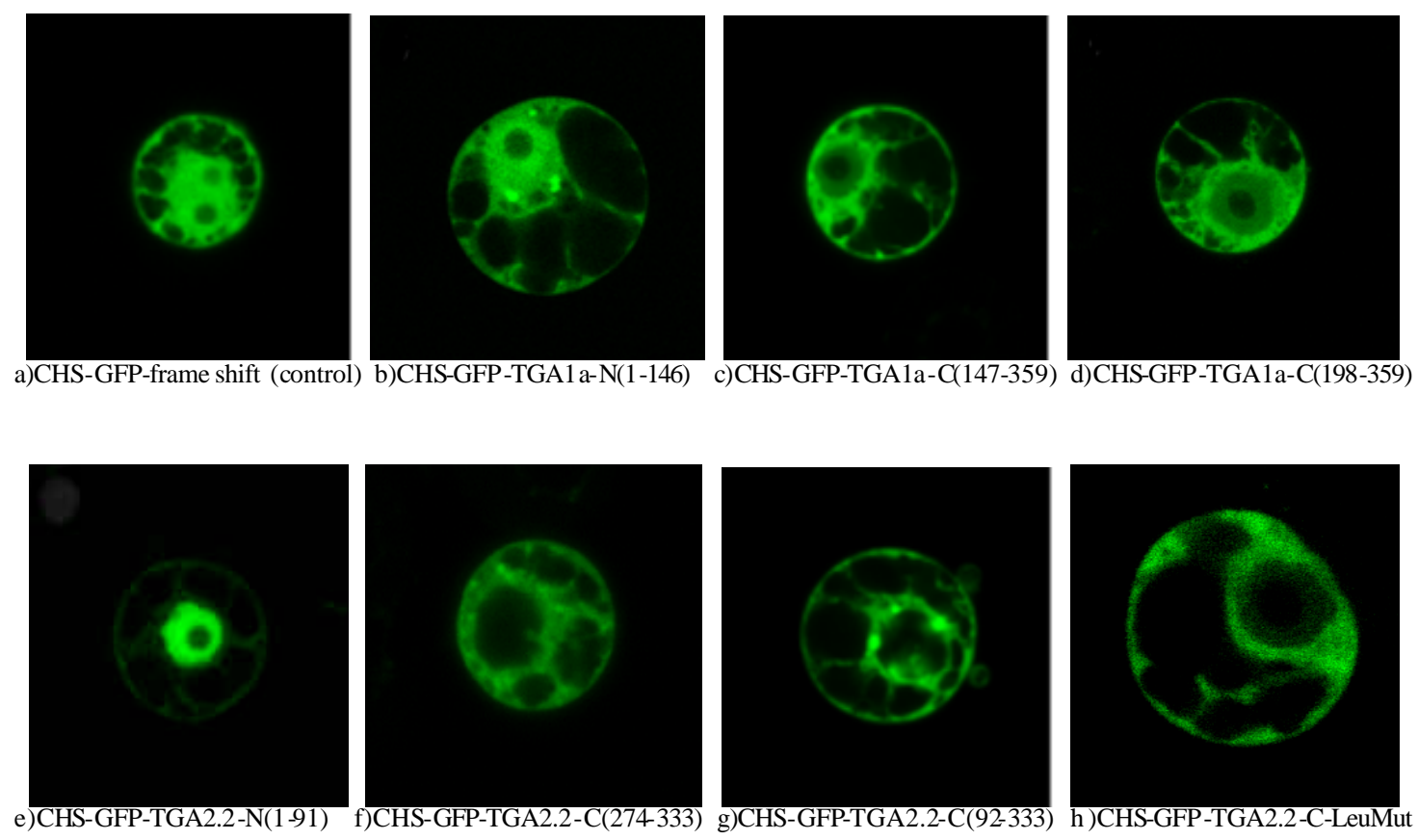

Fig. 4.12. Localization of the different domains of TGA factor s fused to CHS -GFP

A frame-shift fusion of CHS-GFP-TGA1a-N-term, in which case actually only a CHSGFP protein was expressed, was used as a control; this protein was distributed evenly between the nucleus and the cytosol (Fig. 4.12 a) which correspond s to the information from Hansen et al., 1999. The N-termini of TGA2.2 (Fig. 4.12 e) and TGA1a (Fig. 4.12 b) which contain the NLS sequences in the bZIP region determined a nuclear localization of their CHS-GFP fusions, whereas the C-terminal fusions of TGA2.2 (Fig. $4.12 \mathrm{f}, \mathrm{g}$ ) and TGA1a (Fig. $4.12 \mathrm{c}, \mathrm{d}$ ) accumulated in the cytosol. The mutation of two leucines in the putative NES of TGA2.2 did not change the localization of the TGA2.2-C-terminal fusion protein (Fig. $4.12 \mathrm{~h}$ ) indicating that the leucine-rich pattern probably has no targeting function. It still is not clear and has to be determined whether the observed cytosolic distribution for the C-terminal fusions is really a result from nuclear export, or because of the lack of nuclear localization signals and the increase of the molecular 
weight those fusions are not imported efficiently or not at all in the nucleus, and how specific is this effect, having in mind the slight difference in the distribution of the $\mathrm{C}$ termini of TGA1a, where a minor fraction is visible in the nucleus, and of the C-termini of TGA2.2 which are almost completely excluded from the nuclear compartment.

The separate $\mathrm{N}$ - and C-terminal domains of the TGA factors were also tested for interaction with the export receptor XPO1 from A. thaliana in collaboration with Dr. Thomas Merkle. For the interaction studies he used TGA factors, cloned in the pGAD vector by Dr. Corinna Thurow (2001), re-cloned separate domains of them in pB42AD and tested all them as prays against AtXPO1a in an yeast two-hybrid (Y2H) system. The results of these experiments are summarized in Table 4.1:

$\begin{array}{lc}\text { TGA factor (domain) } & \text { Interaction with AtXPO1a } \\ \text { TGA1a } & +++ \\ \text { TGA1a }(1-146) & +- \\ \text { TGA1a }(147-359) & ++ \\ \text { TGA1a }(198-359) & - \\ \text { TGA2.2 } & +/- \\ \text { TGA2.2 }(1-269) & - \\ \text { TGA2.2 }(274-333) & - \\ \text { TGA2.2(1-91) } & - \\ \text { TGA2.2(92-333) } & +/- \\ \text { TGA2.1 } & - \\ \text { TGA7 } & -\end{array}$

Table 4.1. Y2H Interactions of domains of TGA factors with AtXPO1a

Summarizing the outcome from the $\mathrm{Y} 2 \mathrm{H}$ interaction studies, only TGA1a seems to interact directly with AtXPO1 and this property is determined by the 147-359 a.a. region (or maybe even by the narrower 147-198 a.a. region), while TGA2.1 and TGA7 show no direct interaction with AtXPO1. The Y2H tests for TGA2.2 and for its $\mathrm{C}$-terminus give somehow ambiguous results, but as long as the CHS-GFP-TGA2.2C construct shows a possible export activity in BY-2 protoplasts (Fig. $4.12 \mathrm{f}-\mathrm{h}$ ) the explanation might be that there is no direct interaction with the export receptor but perhaps another plant protein (and its yeast functional homologue) is involved in the presentation and the export of TGA2.2. Another hypothesis might be that in order to be able to interact effectively with the export receptor TGA2.2 needs additional post-translational modification, which not occurring in the yeast cells and that leads to the $\mathrm{Y} 2 \mathrm{H}$ ambiguity. Combining the data from the localization experiments with the $\mathrm{d}$ ata from the $\mathrm{Y} 2 \mathrm{H}$ screen (Table 4.1) it can be summarized that the leucine-rich motif at the C-termini of TGA transcription factors seems not to be a NES of the XPO1-recognizable type and further analysis will be necessary to determine the sequences coding for the TGA1a-XPO1 direct interaction and for the possible export of TGA2.2. 


\subsubsection{Subcellular sorting of homo-/hetero-dimers}

The homo- and hetero-dimers of TGA transcription factors might play different roles in the regulation of gene activity from pathogen-induced promoters, therefore the cells might have mechanisms to sort out the necessary dimers for a specific purpose from the general pool of TGA dimers and to regulate their distribution between the cytosol and the nucleus. This hypothesis was tested by co-expressing transiently TGA-GFP or GFP-TGA fusion proteins with equal amounts of non-GFP-tagged TGA dimer counter-partners i.e. TGA2.2 for GFP-derivatives of TGA2.1 and vice versa; the B-glucuronidase (GUS) protein under the control of the HBT promoter was co-expressed as a negative control. 15 $\mu \mathrm{g}$ of plasmid DNA carrying the TGA-GFP (see 4.1.1) or GFP-TGA (see 4.1.2) constructs was pooled with $15 \mu \mathrm{g}$ plasmid coding for non-GFP-tagged TGA factors or for GUS (pHBT-2.1; pHBT-2.2; pHBT-GUS; all non-GFP plasmids generous gift from Dr. Corinna Thurow) and with those mixtures BY-2 protoplasts were transfected. The samples were incubated overnight for expression of the transfected constructs, the GFP chromophore was excited at $488 \mathrm{~nm}$ and fluorescence visualized by CLSM (Fig. 4.13)

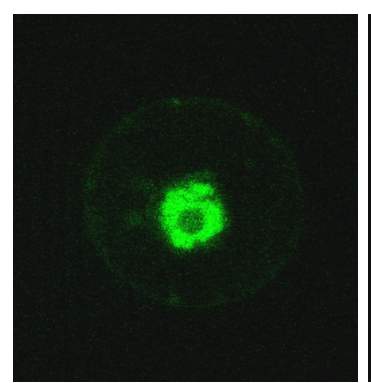

TGA2.1-GFP \& TGA2.2

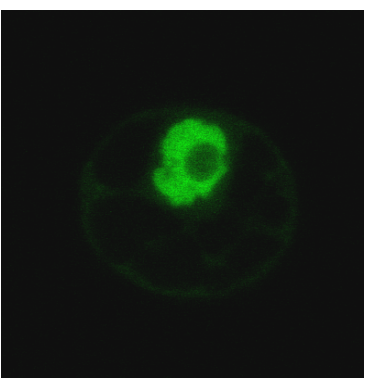

TGA2.1-GFP \& GUS

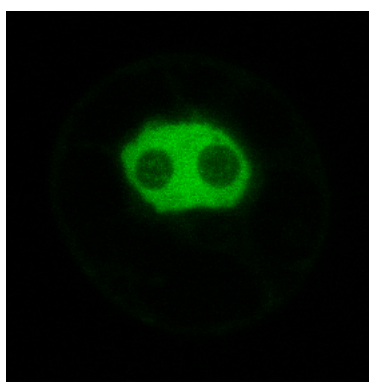

TGA2.2-GFP \& TGA2.1

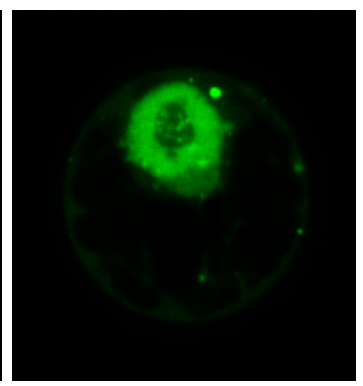

TGA2.2-GFP \& GUS

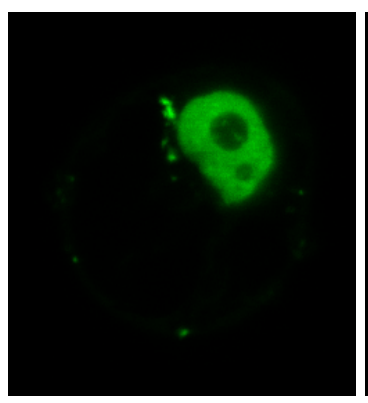

GFP-TGA2.1 \& TGA2.2

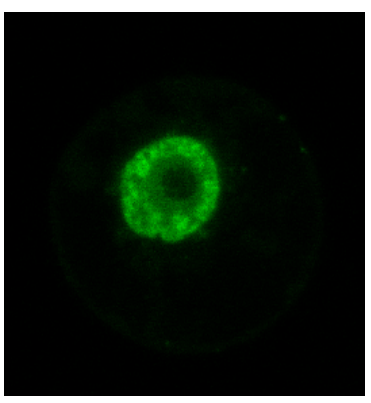

GFP-TGA2.1 \& GUS

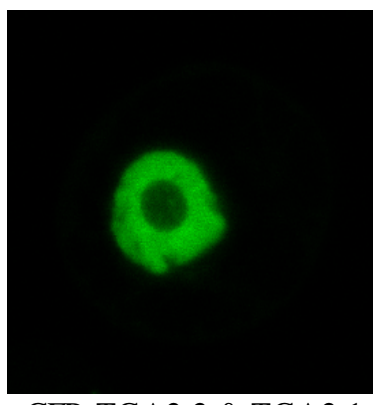

GFP-TGA2.2 \& TGA2.1

Fig. 4.13. Localization of GFP-tagged TGA factors, co-expressed with non-GFP-tagged TGA factors (or GUS)

As seen on the photos on Fig. 4.13, there are no significant detectable differences in the subcellular localization of TGA-GFP or GFP-TGA fusion proteins - no matter whether they have been co-transfected with TGA factors or with GUS, all GFP fusion proteins follow the already-shown pattern of accumulation in the nucleus (and out of the nucleolus). 


\subsection{Stable expression of TGA-GFP fusions in Nicotiana tabacum}

Protoplasts are plant cells, which are influenced more or less by the various types of stress (wounding, osmotic changes, electric fields, etc.) during the preparation and transfection procedures, which could affect the activity and the localization of various proteins. An additional problem is that the level of transfection varies in each experiment, so in general they are suitable for qualitative but not so much for quantitative studies. In order to circumvent these problems, transgenic tobacco plants that stably express TGA2.1-GFP, TGA2.2-GFP, TGA1a-GFP and TetR-GFP fusions were created via Agrobacterium-mediated transformation of leaf discs (3.4.3.5). The regenerated shoots, which were able to grow on selective Kan-containing medium, were grown further on solid 2MS medium in glasses under sterile conditions. Thin epidermal tissue samples, peeled from leaves of those plants were screened for GFP fluorescence by confocal laserscanning microscopy (CLSM, see 3.9.3); equivalent tissue samples from SNN plants were used as a control for auto-fluorescence of the plant tissues (Fig. 4.14)

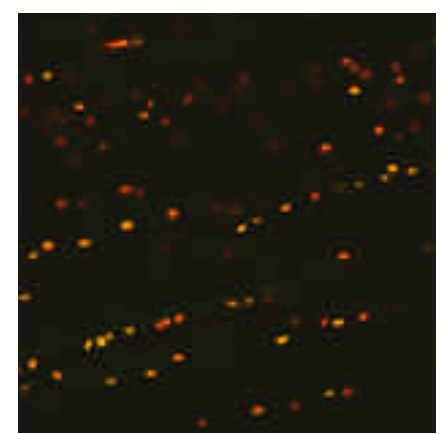

a) SNN (wt)

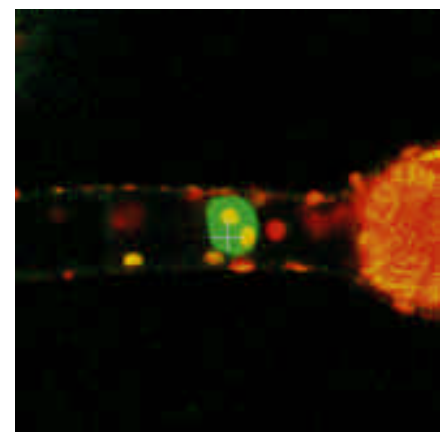

d) TGA2.2-GFP

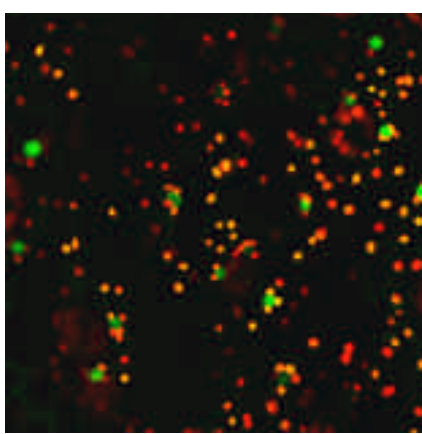

b) TGA2.1-GFP

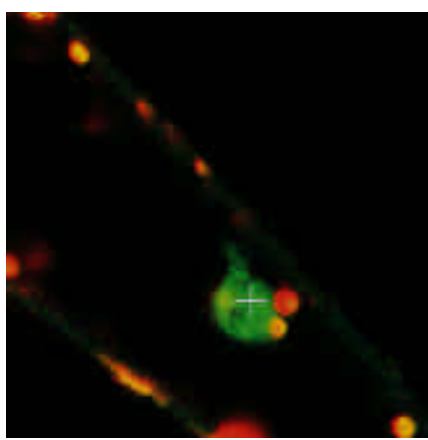

e) TGA1a-GFP

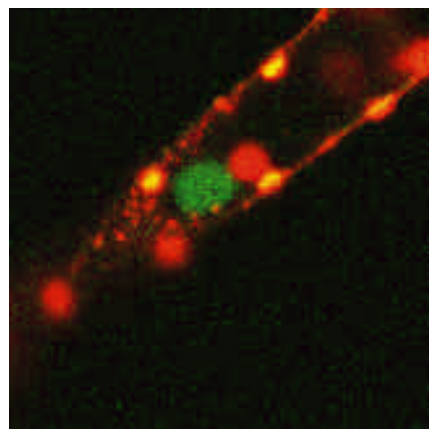

c) TGA2.1-GFP

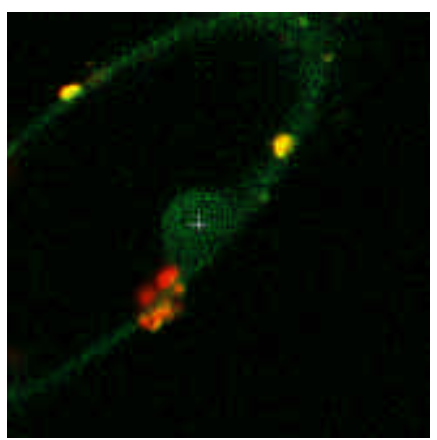

f) TetR-GFP

Fig. 4.14. GFP fluorescence detected in samples from TGA-GFP transgenic plants

Pseudo-colored CLSM images of single trichoma cells and epidermal tissues of transgenic plants grown in sterile conditions and stably expressing different TGA-GFP (TetR-GFP) fusion proteins; the different constructs are indicated under each picture. Observations were performed with a LSM 510 confocal laserscanning microscope (Zeiss) with a C-Apochromat water immersion $40 \mathrm{x}$ objective; the microscope was calibrated with a standard dye (Alexa 488, Molecular Probes, Eugene); the GFP chromophore was excited by $488 \mathrm{~nm}$-illumination provided by an Ar-Ion laser. The red color is due to auto-fluorescence of the chlorophyll pigments at this wavelength. 
In these microscopical measurements no significant GFP-like fluorescence was detected in leaf tissues from the wild-type plant (SNN, Fig. 4.14 a). The analysis of the GFP emissions in tissues of transgenic plants reveals an even distribution between the nucleus and the cytosol for the control TetR-GFP fusion protein (Fig. $4.14 \mathrm{f}$ ) and predominantly nuclear localization for the TGA-GFP fusion proteins (Fig. 4.14 b, c, d, e) - results, which ae similar to those ones obtained from the transient assays studies (4.1.2) and which again show the natural tendency for strong nuclear accumulation of the TGA transcription factors. The positive lines from the GFP fluorescence screen are summarized in Table 42:

\begin{tabular}{|l|l|l|}
\hline HBT::TGA2.1-GFP & $\# 5,6,13,14,20,22,26,30$ & out of 30 lines \\
\hline HBT::TGA2.2-GFP & $\# 1,4,5,8,9,11,14,16,17,18,21,22,27,30$ & out of 30 lines \\
\hline HBT::TGA1a-GFP & $\# 8,9,12,13,15,16(+/-)^{*}, 18(+/-), 19,22$ & out of 22 lines \\
\hline HBT::TetR-GFP & $\# 7,12,13(+/-)$ & out of 14 lines \\
\hline
\end{tabular}

Table 4.2. Summary of TGA/TetR-GFP positive transgenic tobacco lines

* (+/-) stands for ambiguous GFP-like fluorescence, samples were not determined visually with certainty.

Positive transgenic lines from the screening for GFP fluorescence were characterized further at mRNA level by Northern blotting and hybridization with a $0.6 \mathrm{~kb}$ GFP probe, derived as an NcoI / Bpu 10I fragment from the pHBT-L-sGFP plasmid (Fig. 4. 15)

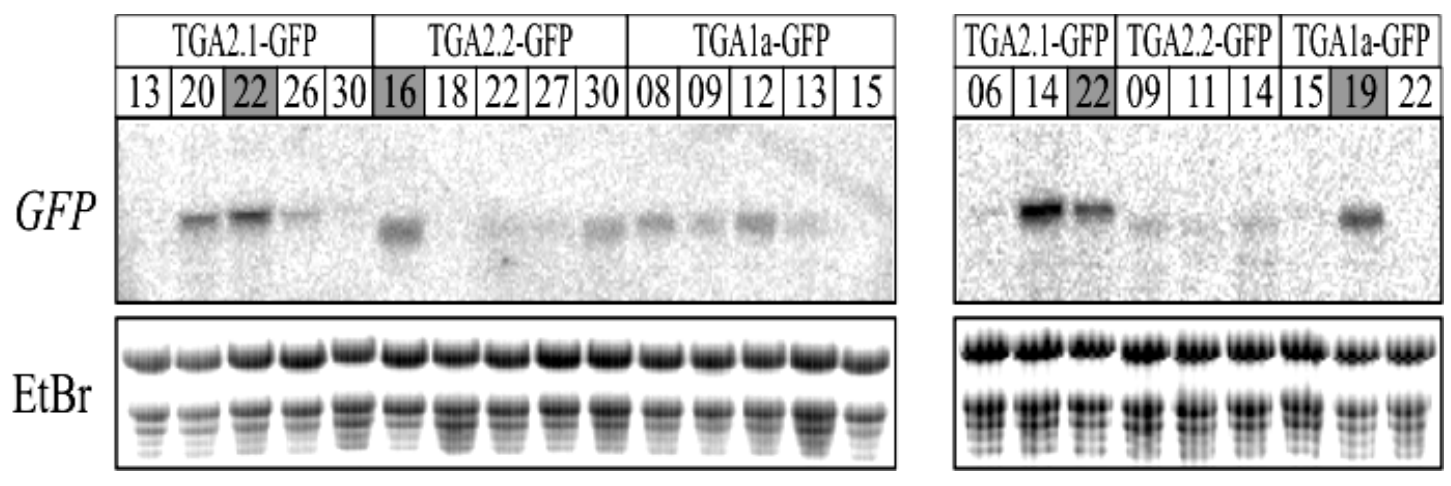

Fig. 4.15. Northern blot analysis of TGA -GFP transgenic plants

$20 \mu \mathrm{g}$ of total RNA isolated from leaves of TGA2.1-GFP, TGA2.2. and TGA1a-GFP independent transgenic lines were separated on denaturing agarose gels, blotted on Hybond ${ }^{+}$membrane and hybridized with a radioactively labeled GFP probe; in the lower panel the EtBr staining of the blots is given as control for the loading. Transgenic lines are numbered on top of the blots; RNA from TGA2.1-GFP line \#22 was loaded on both blots for comparison.

As long as not all transgenic lines showed similar mRNA level of the TGA-GFP fusions, TGA2.1-GFP line \#22, TGA2.2-GFP line \#16 and TGA1a-GFP line \# 19 (marked with grey boxes on Fig. 4.15) with comparable levels of expression of the transgene were selected and used for further biochemical studies. 


\subsection{1. as-1-binding activity in TGA-GFP transgenic plants}

To analyze whether the TGA-GFP fusion proteins are still able to recognize and bind the as-1 element, an electrophoretic mobility shift assay (EMSA) with crude protein extracts from transgenic plants expressing the TGA-GFP fusions was performed. $30 \mu \mathrm{g}$ of protein from Fix Prot extracts (3.7.3.5) from wild-type and transgenic tobacco plants grown in sterile conditions were incubated with a radioactively-labeled as-1 fragment, the interaction complexes of hot DNA fragment and DNA-bound proteins were separated on a native $5 \%$ PAGE and visualized by radiography. The non-specific DNA-binding activity in the samples was eliminated with the addition of $0.3 \mu \mathrm{g} / \mu \mathrm{l}$ poly-dIdC in the binding reactions. The as- 1 element is a target for either a single- or double-dimer occupation, which results in two visible bands in wild-type extracts (Fig. 4.16, lane 5). As long as the GFP tag adds additional $27 \mathrm{kDa}$ to the molecular weight of the TGA-GFP fusion proteins, the DNA-protein complexes built of homo- or hetero-dimers of the TGAGFP fusions (Fig. 4.16, lanes 2, 3 and 4) show significant retardation in their mobility in gel compared to complexes built of endogenous TGA factors only (Fig. 4. 16):

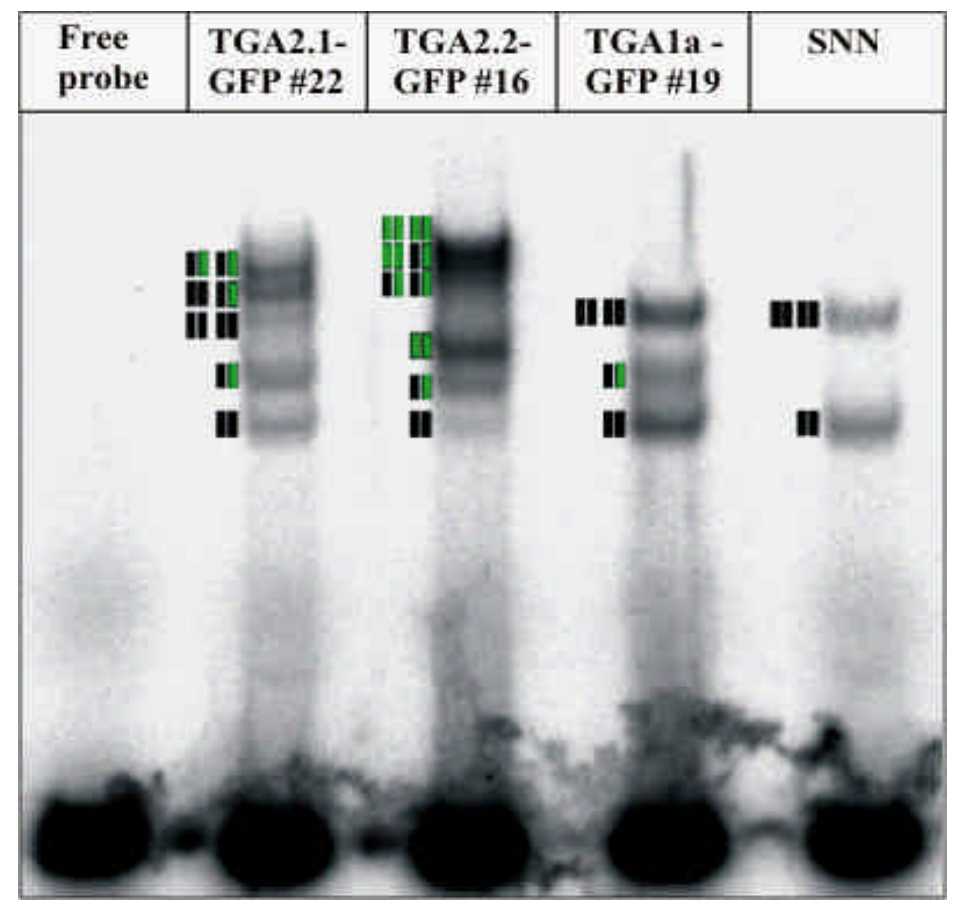

Fig. 4. 16. as-1-binding activity in crude extracts from TGA-GFP transgenic plants.

The interaction complexes of $30 \mu \mathrm{g}$ protein from Fix Prot extracts and $2 \mu \mathrm{l}$ of radioactively labeled as- 1 fragment were separated on a $5 \%$ native PAGE. The different homo - or hetero-dimers complexes are given schematically, where one $\mathbf{I}$ box represents a single endogenous TGA factor protein (see SNN, lane 5) and one box represents a single molecule from the different TGA-GFP fusion proteins (TGA2.1-GFP, lane 2; TGA2.2-GFP, lane 3; TGA1a-GFP, lane 4); coupled boxes represent the combinations of TGA homo-or hetero- dimers. TGA2.2-GFP and TGA2.1-GFP bound to $a s-1$ both as a single or double dimer occupation in different combinations (see legend), while TGA1a-GFP bound to as- 1 only as a single hetero-dimer with endogenous TGA2.2, which ran higher than the TGA2.2:TGA2.2-GFP heterodimer but lower than the TGA2.2-GFP homodimers (see lane 3). 


\subsubsection{Influence of TGA-GFP fusions on the SA or 2,4-D - inducible gene expression}

After showing that the TGA-GFP fusion proteins maintain their DNA-binding properties (4.2.1) the next step was to find out whether TGA-GFP fusions have also preserved their functionality i.e. whether they still can influence the expression of pathogen-induced genes after elicitation. In most plant tissues the as-1 element is not constitutively active; several substances (salicylic acid, auxin (2,4-D), etc.) can influence the transcription from as-1-containing promoters. In this work the changes in the mRNA level of Nt103 (an immediate-early SA-responsive gene encoding for a glutathione-S-transferase) after SA or 2,4-D induction were studied in transgenic plants expressing TGA2.1-GFP (line \#22), TGA2.2-GFP (line \#16) and TGA1a-GFP (line \#19) fusion proteins (see 4.2); induced SNN or $a s-1$-Gus plants were used as control.

\subsubsection{Influence of TGA2.X-GFP factors on the level of Nt103 mRNA - /+ SA induction}

Leaf discs from hydroponics plants were floated on $20 \mathrm{mM}$ potassium phosphate buffer pH 5.8 containing $1 \mathrm{mM}$ salicylic acid or $50 \mu \mathrm{M} 2,4-\mathrm{D}$, samples were collected at the start and at certain time points afterwards, flash-frozen in $\mathrm{N}_{2}$ and used for isolation of total RNA, which was then separated on denaturing agarose gels and blotted onto Hybond $^{+}$membranes. The hybridization was performed with a radioactively labeled Nt103 $1 \mathrm{~kb}$ EcoRI-fragment from pCNT103 (Van der Zaal et al., 1991), the membranes were exposed to imaging plates (IP, Fuji) and the signals were detected with a Bioimager using the PCBAS ${ }^{\circledR}$ Reader program (Raytest $\mathrm{GmbH}$ ). A time-course experiment without and with SA induction is shown on Fig. 4.17:

\begin{tabular}{|c|c|c|c|c|c|c|c|c|c|c|c|c|c|c|c|}
\hline$-\mathrm{SA}$ & & 0 hou & & & 1 hou & & & 3 hou & & & 6 hou & & & 24 hol & \\
\hline & WT & $\begin{array}{c}\text { TiA2.11 } \\
\text { GiFP }\end{array}$ & $\begin{array}{c}\text { TGAA2.2. } \\
\text { Cit]P }\end{array}$ & WT & $\begin{array}{c}G G A 2.1 \\
\text { TGAT } \\
\text { (ifr }\end{array}$ & $\begin{array}{c}\text { TiA2 } 2.2 \\
\text { CiFP }\end{array}$ & $\mathrm{WT}$ & $\begin{array}{c}\text { TiAZ2. } \\
\text { GEF }\end{array}$ & $\begin{array}{c}\text { TGAA2.2 } \\
\text { CiFP }\end{array}$ & $\mathrm{WT}$ & $\begin{array}{c}\text { TCAAZ1 } \\
\text { GEP }\end{array}$ & $\begin{array}{c}\text { ThiA2.2 } \\
\text { CiFP }\end{array}$ & $\mathrm{wT}$ & $\begin{array}{c}\text { TiA22.1 } \\
\text { CAPP }\end{array}$ & $\begin{array}{c}\text { TLAAD2 } \\
\text { GEP }\end{array}$ \\
\hline $\mathrm{NilO3}$ & 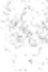 & tos & \% & 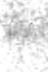 & 3) & 10 & 48 & & & 8 & & 6) & 4 & net. & secte \\
\hline $\mathrm{EtBr}$ & & & & & & & & & & & & & & & \\
\hline
\end{tabular}

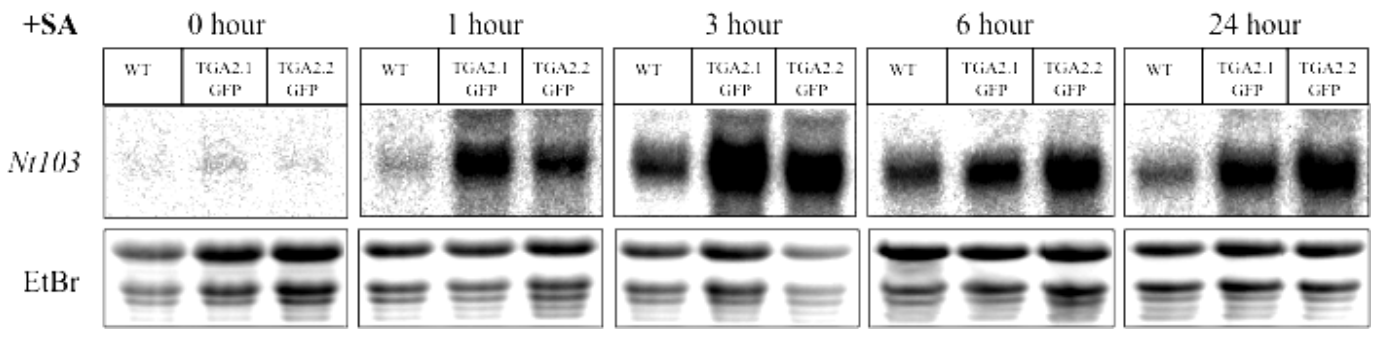

Fig. 4.17. Influence of TGA2.1-GFP and TGA2.2-GFP fusions on the expression of Nt103

Leaf discs from wild type (as-1-Gus) and TGA2.1-GFP and TGA2.2-GFP transgenic plants were incubated in potassium phosphate buffer $+/-1 \mathrm{mM} \mathrm{SA}$; samples were taken at the above-given time points. $20 \mu \mathrm{g}$ of total RNA isolated from the frozen leaf tissue were analyzed by hybridization with a radioactively labeled Nt103 probe. As control for the loading, the EtBr staining of the RNAs is given underneath. 
For quantification measurements the TINA ${ }^{\circ}$ program (Raytest $\mathrm{GmbH}$ ) was used; Nt103 signals were normalized according to the strength of the corresponding rRNA signals, quantified from the EtBr photos of the blots with the same software; additionally the Nt103 signals from transgenic plants were compared to the corresponding one of the wild-type plant. The results of the analysis of this experiment are presented on Fig. 4.18:

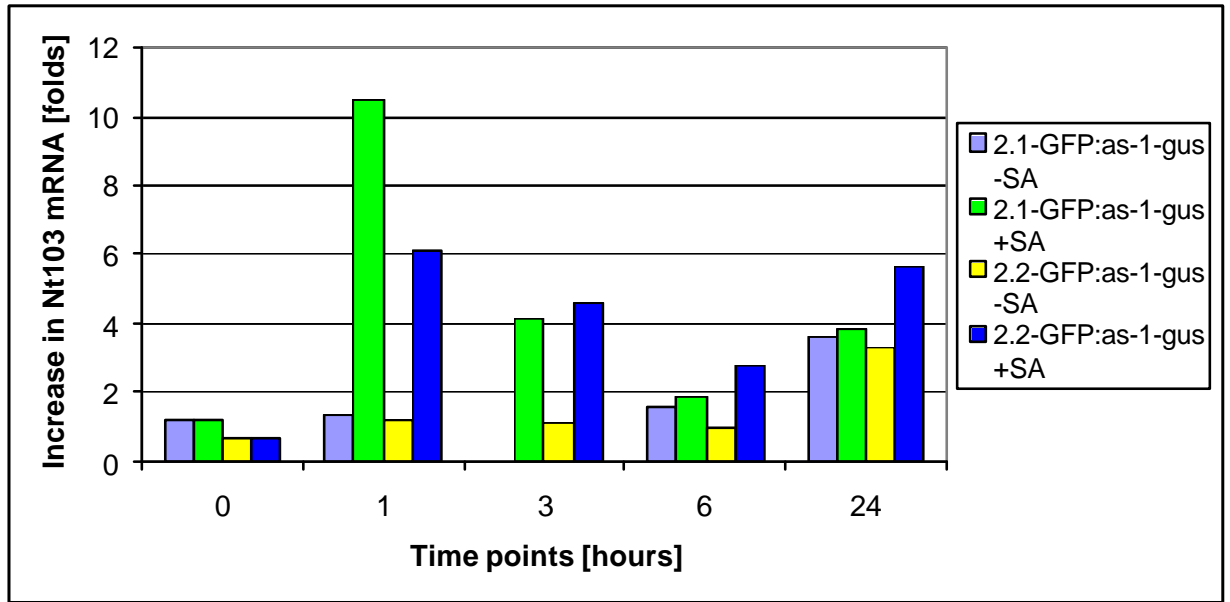

Fig. 4.18. Effects of TGA-GFP fusion proteins on the level of Nt103 mRNA with or without SA Signals were quantified by measuring their density with the TINA® software; ratios of the Nt103 signal were normalized according to the rRNA ratios measured from the EtBr-stained blots. The Nt103 signals from the transgenic plants (given on the legend) were compared to the one from the as-1-Gus plant and data was plotted as ratios between those signals

As seen on Fig. 4.18 without SA there was no effect of the TGA2.1-GFP and TGA2.2GFP fusion proteins on the expression of the immediate-early SA-responsive Nt103 gene in the time range from 0 to 6 hours; still an approximately 3.5-fold increase in the Nt103 mRNA at 24 hours was observed, possibly due to a late SA-independent activation of the transcription from this promoter. In contrast, when SA was applied, there was a very fast (already at 1 hour) and significant increase in the transcription of the Nt103 gene, which was stronger (10-fold at 1 hour) but more transient in case of TGA2.1-GFP, while TGA2.2-GFP showed in this experiment more moderate (46 fold increase) but also longer-lasting effect on the Nt103 transcript levels.

4.2.2.2. Influence of TGA-GFP fusions on the Nt103 mRNA level after SA or 2,4-D treatment

In a subsequent experiment also 2,4-D induction kinetics were studied and material from a TGA1a-GFP-expressing plant was collected in order to investigate the role of TGA1a in leaves in the regulation of the gene expression from as-1-containing promoters. Leaf discs from a control SNN plant and transgenic plants expressing TGA1a-GFP (line \#19), TGA2.1-GFP (line \#22) and TGA2.2-GFP (line \#16) fusion proteins (see 4.2) were floated on phosphate buffer $\mathrm{pH} 5.8$ containing $1 \mathrm{mM} \mathrm{SA}$ or $50 \mu \mathrm{M} 2,4 \mathrm{D} .10 \mu \mathrm{g}$ of total RNA isolated from the frozen tissues were loaded on denaturing agarose gels and after 
electrophoretic separation were blotted onto Hybond ${ }^{+}$membranes and hybridized with a radioactively labeled Nt103 probe (and a GFP probe for the SA induction blot, Fig. 4.19)
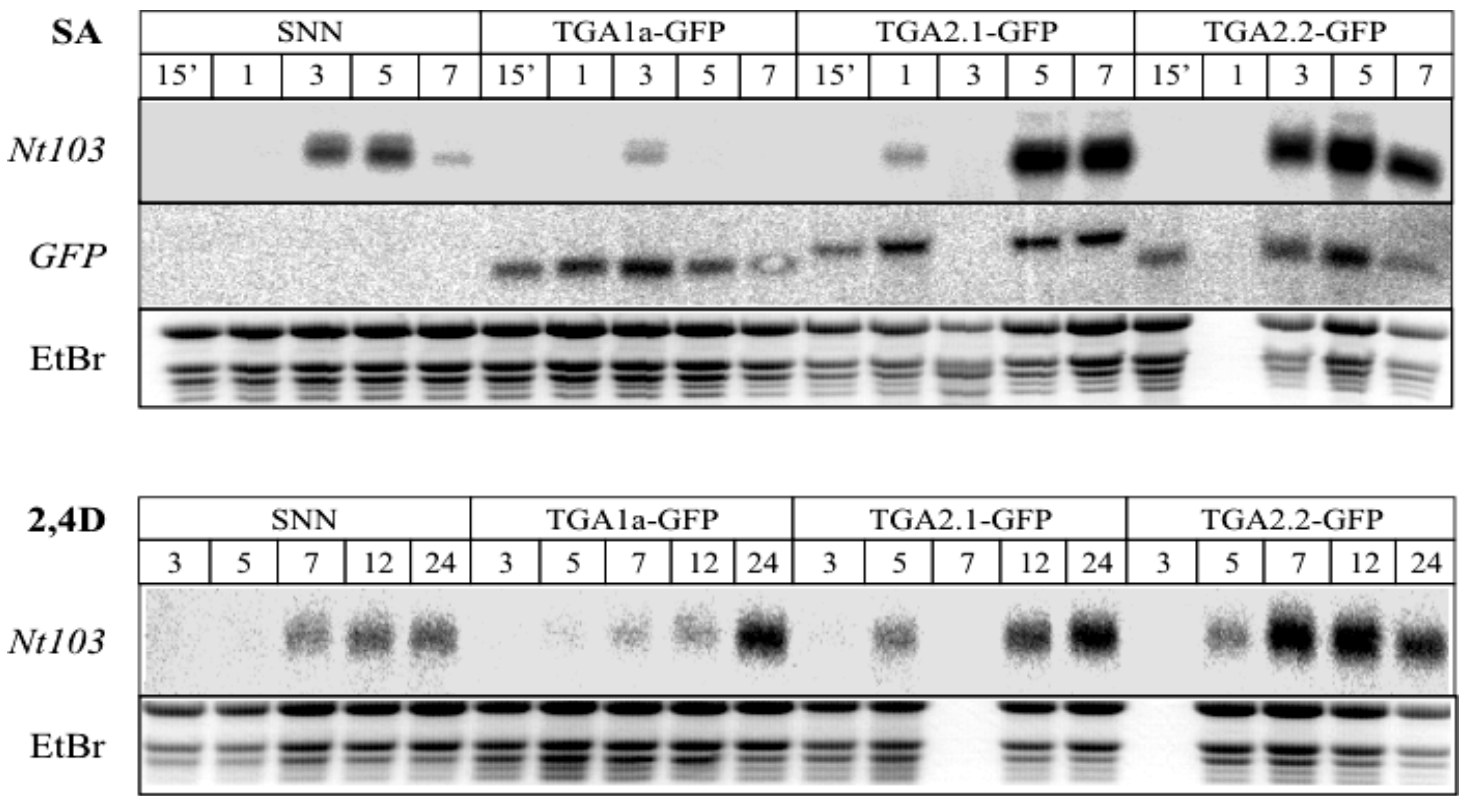

Fig. 4.19. Influence of the TGA-GFP fusion proteins on the expression level of $N t 103$ in leaves after SA or 2,4-D treatment

$10 \mu \mathrm{g}$ of total RNA from treated with SA or 2,4-D leaves of wild type and transgenic plants (TGA1a-GFP \#19, TGA2.1-GFP \#22 and TGA2.2-GFP \#16) were blotted on Hybond+ membranes and hybridized with a radioactively labeled $\mathrm{Nt} 103$ probe. The upper panel shows the SA induction time course, the lower panel the 2,4-D induction time course. Time points and plants are marked on top of blots; the EtBr staining is shown as a control for the loading.

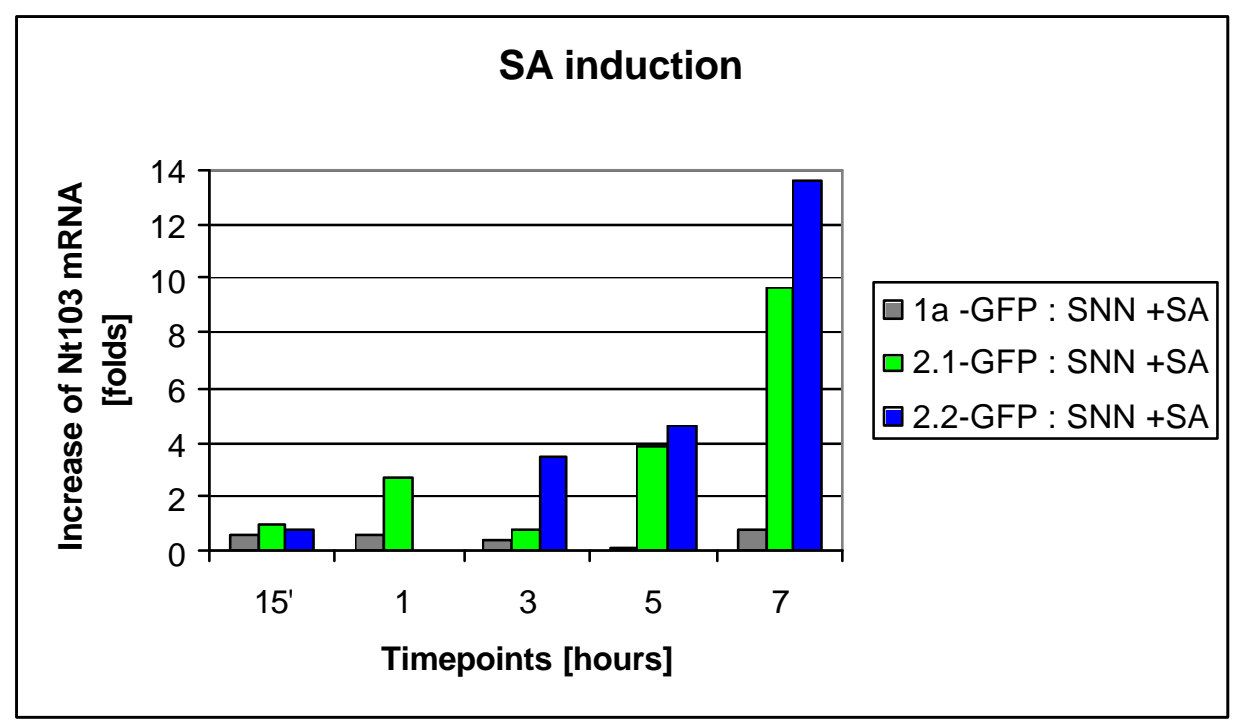

Fig. 4.20 a. Increase in the level of $N$ t103 expression after SA induction in TGA-GFP transgenic plants compared to an SNN plant. 


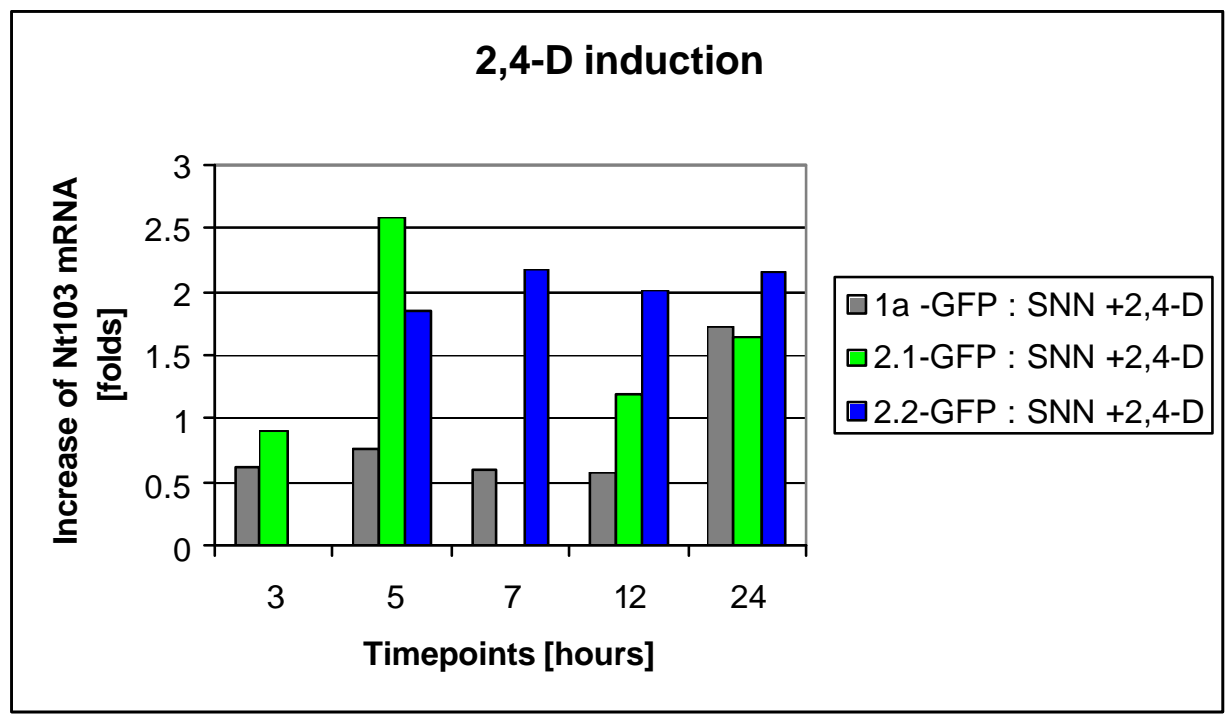

Fig. 4.20 b. Increase in the level of Nt103 expression after 2,4-D induction in TGA -GFP transgenic plants compared to an SNN plant.

Nt103 mRNA signals were normalized according to the strength of the corresponding rRNA signals, quantified from the EtBr staining of the blots; additionally the Nt103 signals from the transgenic plants were compared to the one from the SNN plant and data was plotted as ratios between those signals .

The analysis of the data from the Northern blots (Fig. 4.19) and after normalization of the signals (Fig. $4.20 \mathrm{a} \& \mathrm{~b}$ ) reveals a possible difference in the activation properties of TGA1a on one side and TGA2.1 and TGA2.2 on the other - while the GFP-fusions of TGA2.1 and TGA2.2 conferred several-fold higher level of expression of the target gene both after SA or 2,4-D stimulation, the TGA1a-GFP fusion in leaves seemed to influence negatively the transcription of the Nt103 gene, probably by forming non-functional heterodimers with endogenous TGA factors and/or by binding to the as- 1 element and occupying binding sites for the SA- or 2,4D-activated endogenous TGA dimers. TGA2.1-GFP and TGA2.2-GFP were able to regulate positively the transcription of Nt103 gene upon SA induction with a maximum at 5 and 7 hours (about 4 respectively 10-12 fold) in this experiment, while the effect on 2,4D-inducible transcription was between $1.5-2.5$-fold increase in the Nt103 mRNA level.

\subsubsection{Influence of TGA-GFP fusion proteins on the expression level of Nt103 after SA} or 2,4-D treatment in leaves in different developmental stages

To answer the question whether the regulatory functions of the TGA factors may vary during the different developmental stages of the tobacco leaves the expression of the Nt103 gene after SA or 2,4-D induction was studied in juvenile leaves (\# 1,2,3,), a more expanded leaf (\# 5) and a mature non-senescent leaf (\# 8); for numbering see Fig. 4.21. Leaf discs from an SNN, TGA1a-GFP \# 19, TGA2.1-GFP \#22 and TGA2.2-GFP \#16 plants were incubated for certain time points in $20 \mathrm{mM}$ potassium phosphate buffer $\mathrm{pH}$ 5.8 containing $1 \mathrm{mM}$ SA or $50 \mu \mathrm{M} 2,4 \mathrm{D}$, total RNA was isolated, blotted and hybridized with radioactively labeled Nt103 and GFP probes (Fig. 4.22). 


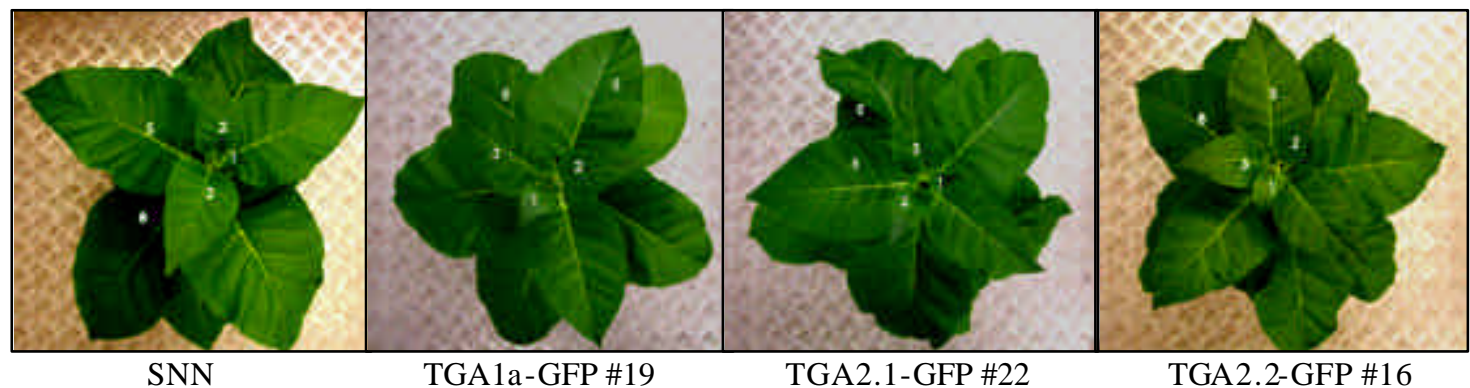

Fig. 4.21. Numbering of leaves of SNN and transgenic plants, used for SA- or 2,4-D-induction studies
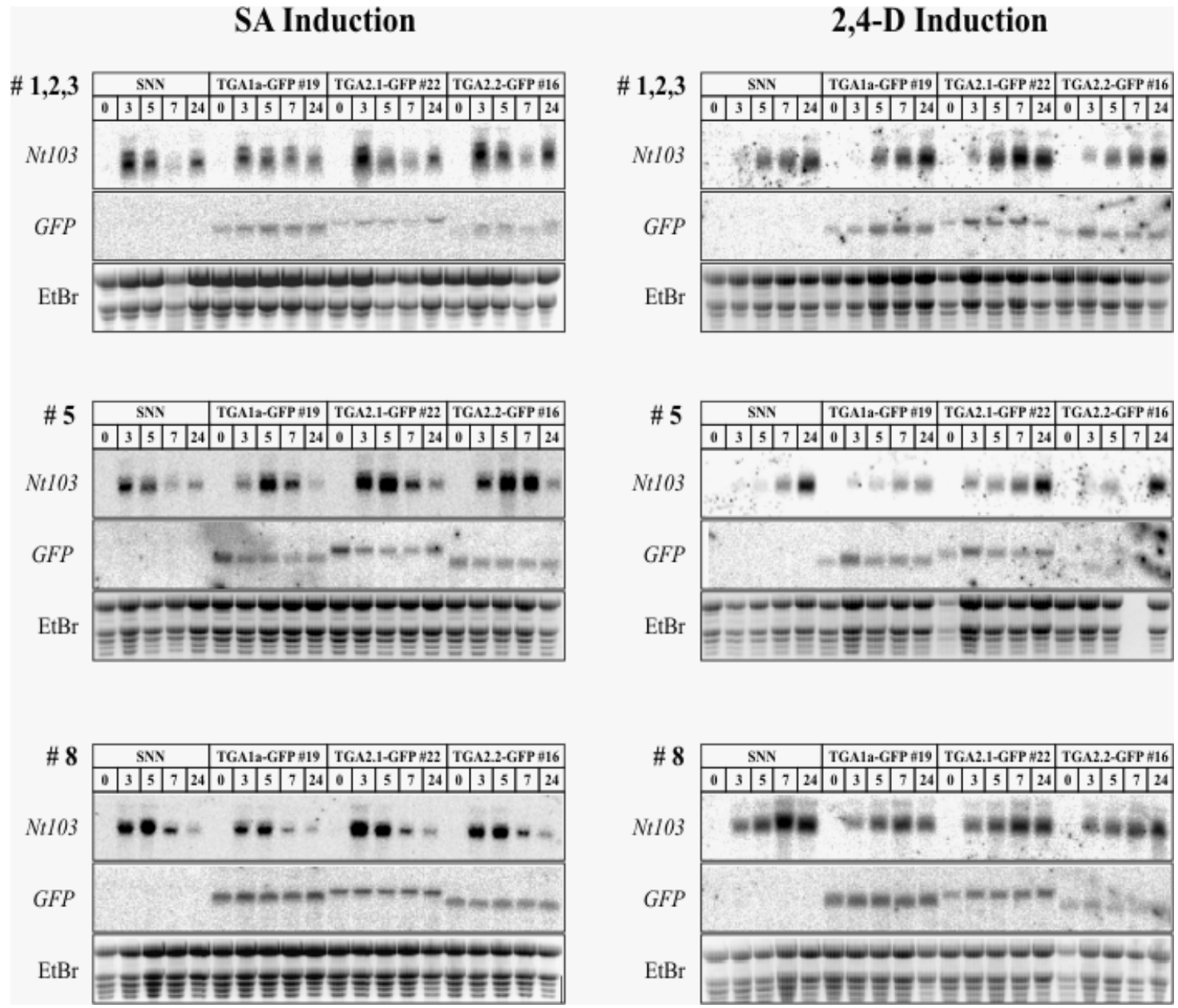

Fig. 4.22. SA- and 2,4-D- induction time courses of juvenile (\# 1,2,3), more expanded (\# 5) and mature (\# 8) leaves from SNN and TGA -GFP transgenic plants.

10-20 $\mu \mathrm{g}$ total RNA from induced leaf discs were separated in denaturing conditions, blotted on Hybond ${ }^{+}$ membranes, hybridized with radioactively labeled Nt103 probe and after stripping re-hybridized with a GFP probe (probes marked of the left side of the blots); plants and time points are marked on top of each blot; EtBr staining of the RNAs is given as a control for the loading. 
Nt103 mRNA signals quantified with TINA® were normalized according to the strength of the corresponding rRNA signals, quantified with the same program from the EtBr photos of the Northern blots; additionally the Nt103 signals from transgenic plants were compared to the corresponding one of the wild-type plant and data was plotted as normalized Nt103 signal ratios of transgenic versus wild-type plants (Fig. 4. 23)
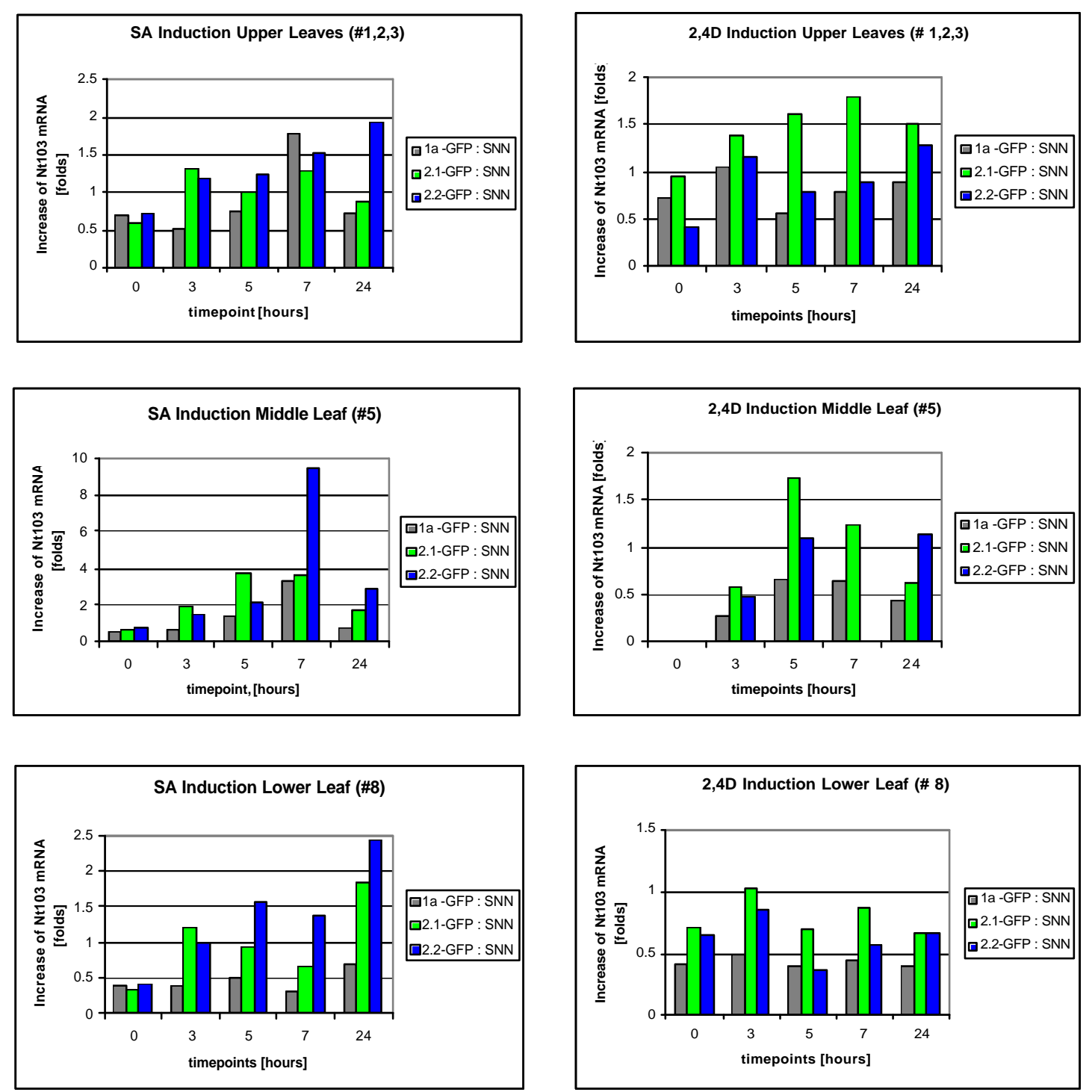

Fig. 4.23. Increase in the level of Nt103 expression after SA or 2,4-D induction of leaves in different developmental stages from SNN and TGA-GFP transgenic plants.

Nt103 mRNA signals were normalized according to the strength of the corresponding rRNA signals, quantified from the EtBr staining of the blots; additionally the Nt103 signals from the transgenic plants were compared to the one from the SNN plant and data was plotted as ratios between those signals. 
Summarizing the results from the SA and 2,4-D induction time courses performed with tobacco leaves in different developmental stages, it seems that TGA-GFP fusion proteins had different effects on the level of expression of the reporter gene Nt103:

The presence of the GFP fusion of the root-specific TGA1a transcription factor (TGA1aGFP) in leaves in general influenced negatively the transcription of the Nt103 mRNA both in response to the SA and 2,4-D stimuli, no matter how old the leaf tissue was; some exceptions from this rule can be observed at the 7 hours time point from the SA induction of juvenile leaves (approx. 1.7 -fold increase) and at 7 hours from the SA induction of leaf \#5 (more than 3-fold increase), but this might be an artifact due to the unusually low level of Nt103 mRNA in the samples from the SNN plant (see Fig. 4.22); most of the samples from the TGA1a-GFP \#19 transgenic plant show approx. $50 \%$ of the Nt103 mRNA compared to the level in the wild type plant in both SA and 2,4-D induction series, therefore it seems that the activation of the TGA1a-GFP either via the SA-or via the 2,4-D signaling pathways represses the transcription from the Nt103 promoter, probably by occupying the as-1 element with non-functional heterodimers of TGA1aGFP and endogenous TGA factors and/or by interactions of TGA1a-GFP with other activated proteins, which results in the formation of non-functional complexes with them.

In contrast, the TGA2.1-GFP fusion proteins seems to regulate in a positive way the expression of Nt103, an effect which in this experiment is more obvious in the SA induction time courses with leaf \#5 (2-4 fold increase) but also is valid to a weaker extent for the 2,4-D induction of juvenile leaves (\#1,2,3 - 1.5-1.8-fold increase) and also leaf \#5 (1.3-1.7-fold increase). Keeping in mind these results and the results from previous experiments (see the graphics in Fig. 4.18 and 4.20), it seems that the positive effect of the presence of TGA2.1-GFP (which in fact is an over-expression of TGA2.1 if the fusion protein is functionally active) on the expression levels of Nt103 is stronger in case of a stimulation with SA (2-4 fold) than with 2,4-D (1.3-2 fold).

The same conclusion but with different values and somewhat slower but longer-lasting induction kinetics is also valid for TGA2.2-GFP - in this series of experiments the presence of the TGA2.2-GFP fusion protein influenced positively the level of Nt103 mRNA mainly in the SA induction time course with strongest increase values at 7 and 24 hours (about 2-fold increase, maximum 9.5-fold at 7 hours with leaf \#5 treated with SA); those levels are lower than the corresponding ones obtained in previous experiments, but still reveal the positive effect of TGA2.2-GFP on the SA-inducible gene expression in leaves. In this experiment no stimulating effect on the expression of Nt103 in leaf discs treated with 2,4-D was observed. 


\subsection{Biochemical studies}

\subsubsection{Preparation of antiserum recognizing both TGA2.1 and TGA2.2 C-termini}

TGA factors subclass 2 are quite related in their amino acid sequence, especially in the highly conserved bZIP region and the $\mathrm{C}$-terminus, as shown onFig. 4.24:

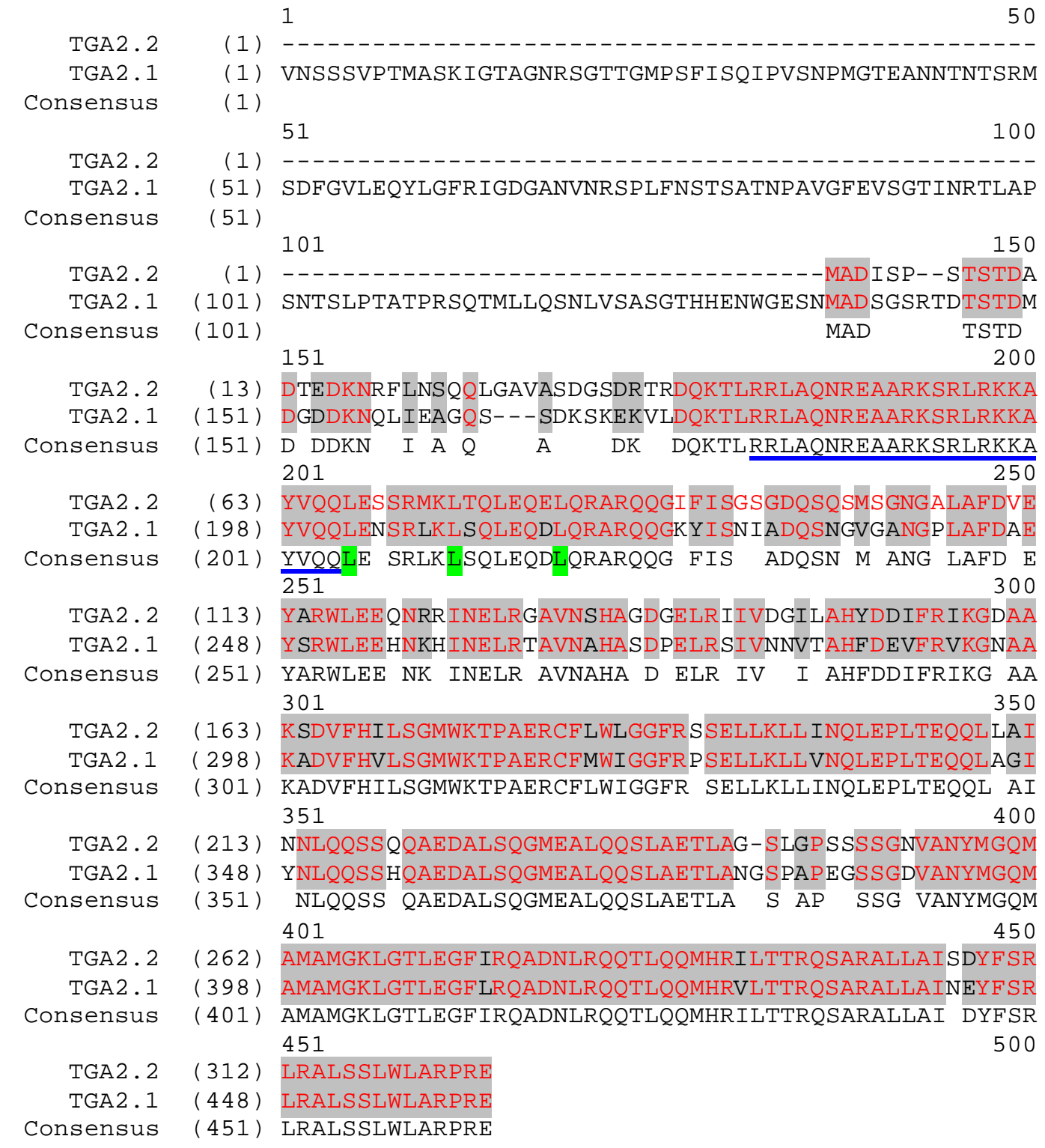

Fig. 4.24. Alignment of the amino acid sequences of TGA2.2 and TGA2.1.

Consensus amino acids are shown in red, the basic region is underlined in blue and the leucines participating in the formation of the leucine zipper are highlighted in green. 
The highly-homologous region (from AYVQQ from the basic region until the SLWLA at the C-termini of the proteins, 260 a.a. in total) of the two proteins had been chosen as an antigen for the preparation of an antiserum, intended to be able to recognize both TGA factors with the same affinity. PCRs were performed on the coding sequences for the introduction of necessary restriction sites for cloning (BamHI and EcoRI) and after an intermediate sub-cloning in pGEM®-T the PCR products were cloned as BamHI / EcoRI fragments in the expression vector pGEX4T-1 (Pharmacia) behind the coding sequence of a glutathione-S-transferase (GST) gene from Schistosoma japonicum, which was under the control of the IPTG-inducible tac promoter. The C-termini of TGA2.1 and TGA2.2 were expressed in E. coli as GST-fusion proteins (3.7.1.2) and affinity-purified on a Glutathione-Sepharose matrix according to the method described in 3.7.1.3 (Fig. 4.25)
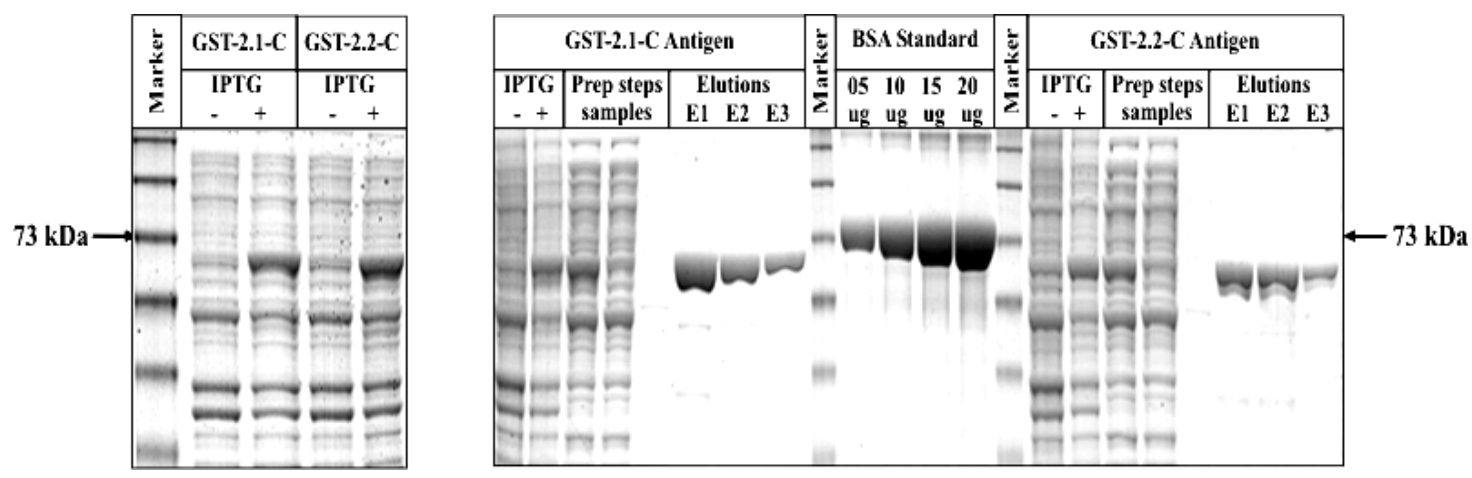

Fig. 4.25. GST-2.XC pr otein expression and purification (Coomassie stained $10 \%$ PAA gels)

The expression of the C-termini of TGA2.1 and TGA2.2 as GST-fusion proteins (apparent molecular weight $\sim 60 \mathrm{kDa}$ ) was performed in E. coli $\mathrm{W} 3110$ strain $500 \mathrm{ml}$ cultures grown overnight at $37^{\circ} \mathrm{C}$, induced with $1 \mathrm{mM}$ IPTG at $\mathrm{OD}_{600}=0.6$ and incubated further at $29^{\circ} \mathrm{C}$ for 3 hours (the conditions for efficient expression of GST-2.X-C as soluble protein had been optimized in advance, see panel a). The GST-2.X-C proteins were affinity-purified from the total E. coli protein on glutathione-Sepharose matrix, different fractions and elutions from the preparation procedures were tested on a $10 \%$ PAGE and stained with Coomassie; BSA standard dilutions were used for estimation of the protein concentrations of the elutions.

$1 \mathrm{mg}$ of pooled GST-2.X-C protein was injected in rabbits for raising an antiserum (immunizations and sera collection was done by the BioScience company, Goettingen). Antibody elutions were prepared from serum of the second bleeding by affinity purification (3.7.2.2) first on GST- and then on GST-2.X-C antigen-coupled Sepharose matrix and used for immuno-detection of TGA proteins and their GFP-tagged variants in nuclear and cytosolic protein extracts. For testing the affinity of the antiserum, antibodies were purified on Sepharose matrix coupled with one of the two recombinant GST-fused C-termini (TGA2.1-C or TGA2.2-C). The elutions from the column were diluted 1:1000 in $1 \times$ TBS- $\mathrm{T}+2 \%$ non-fat dried milk and tested in Western blotting with 10 and $50 \mathrm{ng}$ of the protein, against which it was purified and the same amount of protein from the alternative GST-fused C-terminus (Fig 5.26 a). As a control that the anti-GST specific antibodies were removed by the incubation on the first GST-coupled matrix a Western blot with a dilution series of GST protein (10, 50, 100, $250 \mathrm{ng}$ ) was performed (Fig. 4.26 b) 

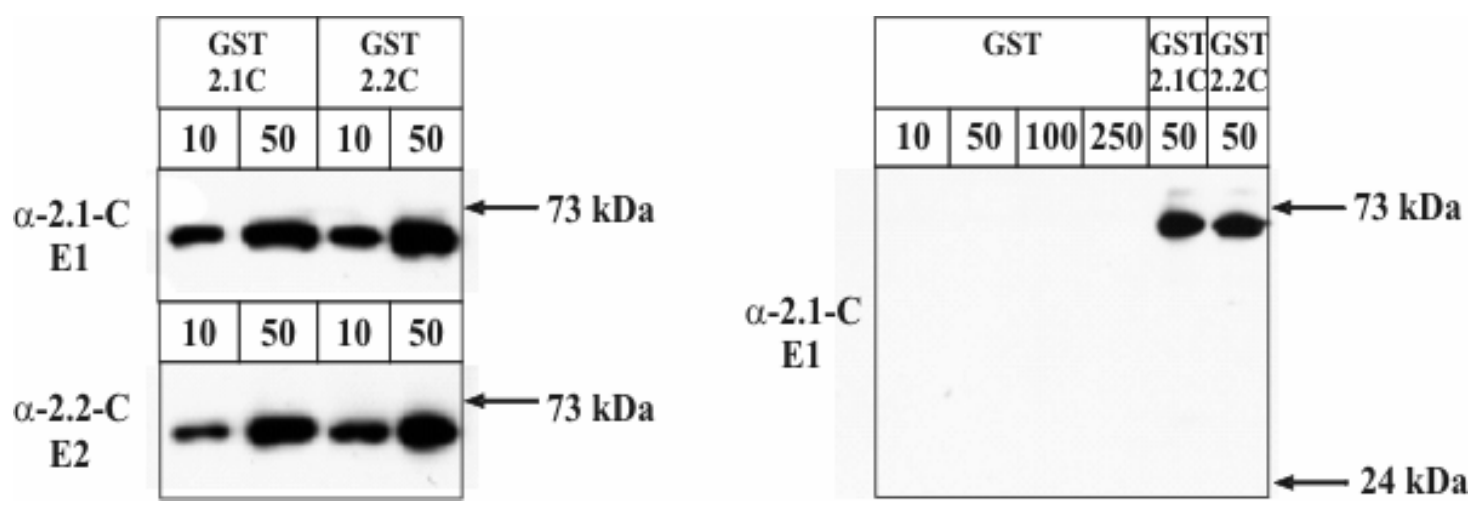

Fig. 4.26. Affinity tests of the a-2.X-C antiserum.

Different elutions prepared from the serum of the $2^{\text {nd }}$ bleeding were tested against the GST-2.X-C antigen (a) and also with GST antigen (b); proteins and amounts marked on top of the blots; antibody elutions are shown on the left side, approx molecular weight in $\mathrm{kDa}$ given on the right side.

As shown on Fig. 4.26 a, antibody elutions prepared on columns with separate TGA2.XC recombinant antigen were able to recognize the alternative $\mathrm{C}$-terminus with the same affinity as they recognized the C-terminus on which they had been affinity-purified; therefore working aliquots from the a-2.X-C antiserum were purified according to the method described in 3.7.2.2 on matrix coated with a pooled GST-2.X-C antigen (3.7.2.1).

\subsubsection{A cytosolic pool of as-1-binding activity is detectable in EMSAs}

Previous data and also EMSA data from this work (see Fig. 4.27) suggested that there might be a significant pool of as-1-binding proteins present in the cytoplasm, which was in contradiction with the nuclear localization of the TGA-GFP fusion proteins, observed in the microscopical studies with the TGA-GFP fusion proteins.

To study the abundance of TGA factors and their GFP-tagged derivatives in protein extracts electrophoretic mobility shift assays (EMSA) were performed with a radioactively labeled as-1-fragment (2.5.1.4). For this purpose native nuclear (see 3.7.3.3) and native cytosolic (see 3.7.3.4) protein extracts from leaves of wild-type (SNN) and TGA-GFP transgenic plants were prepared and protein concentrations of the extracts were determined according to Bradford. Appropriate amounts (see 3.8) of the radioactively labeled as-1-fragment were incubated with $5 \mu \mathrm{g}$ of nuclear or $20 \mu \mathrm{g}$ of cytosolic proteins for $10 \mathrm{~min}$ at room temperature and the DNA-protein interaction complexes were separated on a $5 \%$ native PAGE overnight at $70 \mathrm{~V}$; the gel was dried under vacuum, wrapped in foil and exposed overnight to an imaging plate (IP); the signals were detected from the IP with a BAS-1000 Bioimager (Fuji) using the PCBAS® software. 


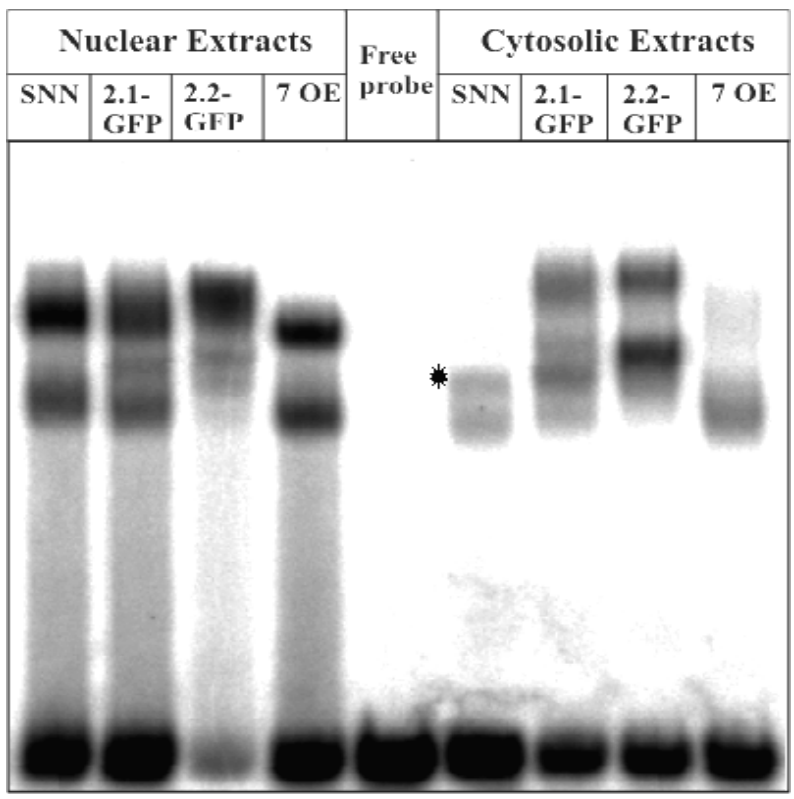

Fig. 4.27. as-1-binding activity in native nuclear and cytosolic protein extracts from leaves of SNN (wt) and TGA2.1-GFP \#22, TGA2.2-GFP \#16 and TGA7 OE \#8 transgenic plants.

$5 \mu \mathrm{g}$ of nuclear and $20 \mu \mathrm{g}$ of cytosolic leaf protein extracts were incubated at RT for 10 min with $2 \mu 1$ of radioactively labeled $a s-1$ fragment and the interaction complexes were separated on a native $5 \%$ PAGE; plants and extracts are marked on top of the EMSA; for legend to the bands (except for the marked with *) see Fig. 4.16.

As expected, the endogenous TGA factors and the TGA-GFP fusion proteins are found in the nuclear protein fraction (Fig. 4.27, left side), still there is a significant amount of as1 -binding activity (Fig. 4.27, right side) in $20 \mu \mathrm{g}$ of the cytosolic extracts. Both nuclear and cytosolic as-1-binding complexes showed binding patterns for complexes composed of endogenous TGA proteins and the combinations between the endogenous factors and the TGA-GFP fusion proteins in the TGA2.X transgenic plants (see also Fig. 4.16); the band designated with an asterisk could not be assigned to a known as-1-binding complex.

\subsubsection{Western blots of nuclear and cytosolic protein extracts from leaves}

For immuno-detection (Western blotting) of the TGA proteins about $15 \mu 1$ of denatured in urea nuclear protein extracts prepared by the method described in 3.7.3.2 (equalized in advance by Coomassie staining of a test gel and quantification of the density of a band on the scanned image with TINA ${ }^{\circledR)}$ and $30 \mu \mathrm{g}$ of native cytosolic extracts (3.7.3.4) denatured at $65^{\circ} \mathrm{C}$ in loading buffer were separated on $10 \%$ SDS-PAGE and blotted on PVDF membranes. After an overnight blocking in $1 \mathrm{x}$ TBS-T $+5 \%$ non-fat dried milk (alternatively $2 \%$ BSA) the membranes were incubated at room temperature for 3 hours with primary antibodies against different domains of the TGA factors, diluted in $1 \mathrm{x}$ TBS-T $+2 \%$ milk (alt. $0.5 \%$ BSA) and for $1 \frac{1 / 2}{2}$ hours with the secondary antibodyperoxidase conjugate diluted in $1 \times$ TBS-T, the membranes were washed and incubated with the ECL+ chemiluminescence reagent, then exposed to a X-ray film and visualized. 
In order to rule out whether cytosolic protein extracts have been contaminated with nuclear proteins during the isolation procedure (3.7.3.4) a control nuclear or cytosolic preparation from a TGA7 over-expressing tobacco plant was always performed in parallel. Membranes were probed with antibodies against both the C-termini of TGA2.1 and TGA2.2 (see 4.3.1) and against the N-terminus of TGA2.1 (Niggeweg, 1999); control blots were performed with antisera against the $\mathrm{N}$-terminus of TGA7 (generated by Dr. Andreas Schiermeyer), against the tobacco TATA-binding protein (TBP) and against the tetracycline repressor (TetR) protein; the results from the Western blots are presented on Fig. 4.28:

\section{Denatured Nuclear Protein Extracts Native Cytosolic Protein Extracts}
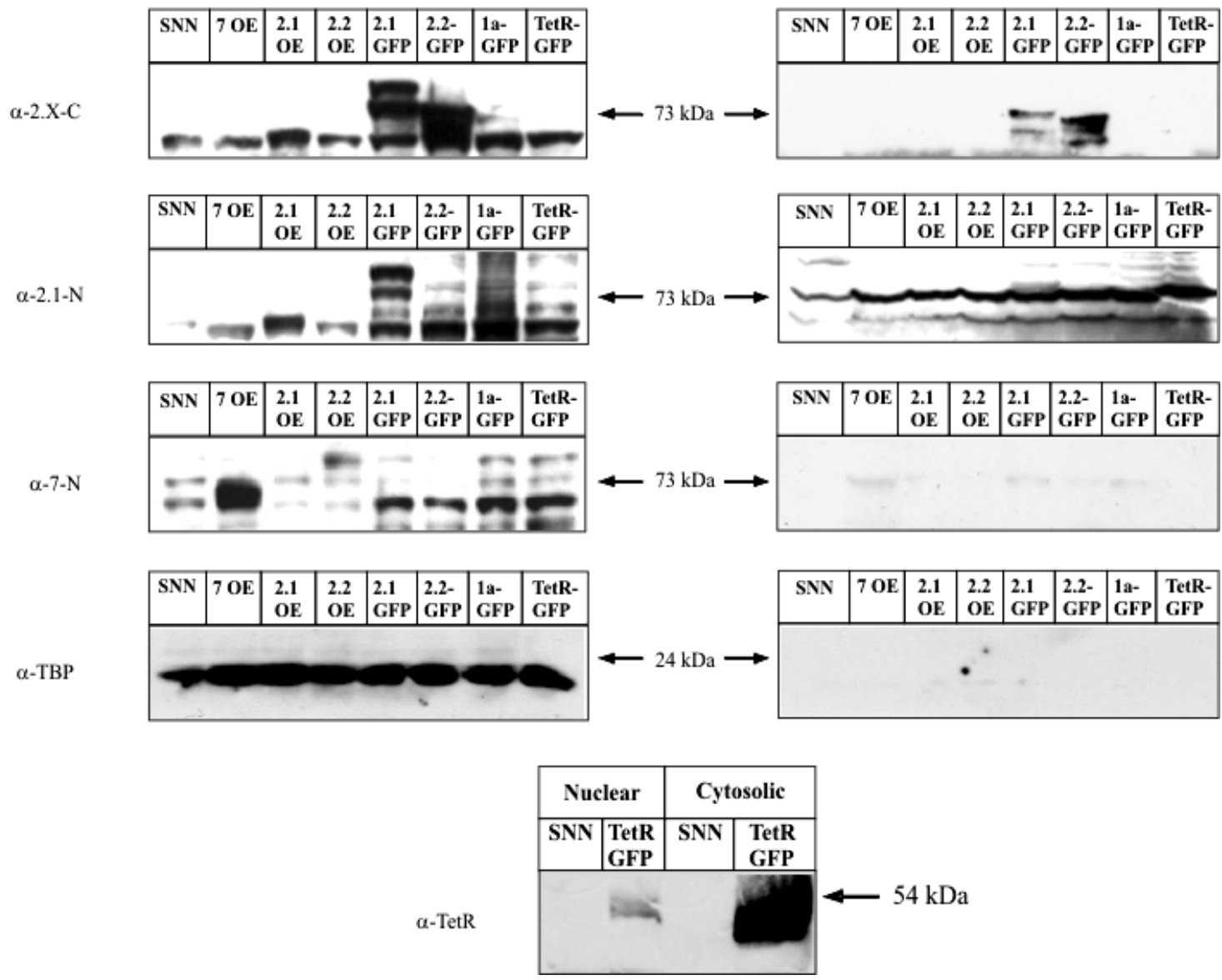

Fig. 4.28. Western blots of nuclear and cytosolic protein extracts

$15 \mu \mathrm{l}$ of denatured nuclear protein extracts and $30 \mu \mathrm{g}$ of cytosolic protein extracts were separated on a $10 \%$ SDS-PAGE, blotted on PVDF membranes and incubated with antibodies against the C-termini of TGA2.1 and TGA2.2 (a-2.X-C, $1^{\text {st }}$ row) and against the N-terminus of TGA2.1 (a-2.1-N, $2^{\text {nd }}$ row); control blots were performed with antisera against the $\mathrm{N}$-terminus of TGA7 (a-7-N, $3^{\text {rd }}$ row), against TBP $\left(\mathrm{a}-\mathrm{TBP}, 4^{\text {th }}\right.$ row) and against TetR (a-TetR, $5^{\text {th }}$ row). Plants and extracts are marked on top of the blots, antisera shown on the left side, approximate molecular size pointed out with arrows. 
The a-2.X-C antiserum was able to detect the TGA2.1-GFP and TGA2.2-GFP fusion proteins both in nuclear and cytosolic extracts (Fig. 4.28, $1^{\text {st }}$ row); the two bands observed were probably due to a detection of both the full-length and some form of truncated protein. This result was confirmed for TGA2.1-GFP using a antiserum recognizing the $\mathrm{N}$-terminus of TGA2.1 (Fig. $4.28,2^{\text {nd }}$ row) and as long as no specific TGA7 signal was detected in cytosolic extracts with the a-7-N antiserum (Fig. $4.283^{\text {rd }}$ row) and with the a-TBP antiserum (Fig. $4.28,4^{\text {th }}$ row) the cytosolic extracts were assumed to be free from cross-contaminating nuclear proteins and the signals in cytosolic extracts were considered from a real cytosolic pool of the TGA2.X-GFP fusion proteins. These cytosolic pools seem to be a minor fraction of the TGA2.X-GFP fusions, which can be seen if we compare the ratio s between the nuclear and the cytosolic fractions of TGA2.1-GFP and TGA2.2-GFP on one side and TetR-GFP on the other (Fig. 4.28, $5^{\text {th }}$ row) which was evenly-distributed between the nucleus and the cytoplasm according to the microscopic pictures (see Fig. $4.14 \mathrm{f}$ ).

\subsection{Mobility behavior and fractions of TGA-GFP fusions in different leaf cell types}

The mobility characteristics of the C-terminally-GFP-tagged TGA transcription factors were studied in living cells under non-inducing and inducing conditions in several tobacco leaf-surface cell types - trichoma cells, stomata guard cell and epidermal cells. The experiments were done in close collaboration with Kirsten Bacia, a PhD student in the group of Dr. Petra Schwille from the Max-Planck Institute for Biophysical Chemistry in Goettingen, Germany. FCS Measurements were performed on a commercial ConfoCor2 / LSM510 combined station (Zeiss, Germany), equipped with a $488 \mathrm{~nm} \mathrm{Ar}$ laser. Tissues were peeled off from the surface of leaves of the transgenic plants and embedded in agarose to reduce the mobility of the sample during the measurements (caused by moves of the microscope objective). As long as the green fluorescence from the TGA-GFP fusions was detectable almost exclusively in the nuclear subcellular compartment, the FCS measurements were most oft en performed in the nuclei of the cell types mentioned above; the red fluorescence on the LSM pictures is due to the autofluorescence properties of the chloroplast pigments illuminated by the laser. LSM pictures were taken before and after FCS measurements to ensure the stability of the position of measurement, which in addition gave the possibility of studying the 'Fluorescence Loss in Photobleaching" (FLIP) effect in the spot of illumination caused by the focused laser light. After selecting a point for measurement on the LSM image (marked on the photos with a white cross) the ConfoCor2 station was switched from LSM to FCS mode; fluorescent signals were detected with a fiber-coupled, actively quenched avalanche photodiode with a time resolution for counting photons of $20 \mathrm{MHz}$ (corresponds to $50 \mathrm{~ns}$ ); the raw experimental data was autocorrelated by the ConfoCor2 software and evaluated using Levenberg Marquardt non-linear least-square fitting to model functions for 1- or 2-component free diffusion. No FCS could be performed in cases when the fluorescent species in the samples were immobile because there was only bleaching of the fluorescent chromophores, therefore only a decrease but no selfsimilarity of the signal. 
4.4.1. Characterization of the mobility properties of TGA2.1-GFP in nuclei of leaf cells

Tissues from TGA2.1-GFP transgenic tobacco plants that showed high level of fluorescence in the screening for GFP signal (\#30 and \# 14, see 4.2) were used for experiments. Leaf discs from plants grown in soil were incubated in $\mathrm{pH} 5.8$ phosphate buffer without or with $1 \mathrm{mM} \mathrm{SA}$, tissue was peeled off from the lower surface of the leaf with sharp pincers, embedded in an agarose drop on a microscopic slide, covered and mounted on the microscope. After visualization of the samples with CLSM the FCS measurements were performed.

\subsubsection{Mobility of TGA2.1-GFP in nuclei of trichoma cells}

The LSM pictures taken before or after the FCS measurements of TGA2.1-GFP in nuclei of trichoma cells are presented on Fig. 4.29:

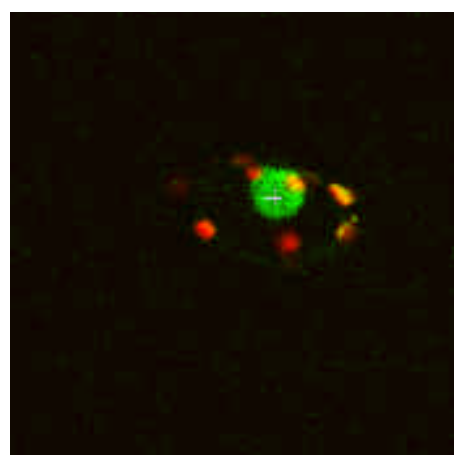

Trichoma cell -SA before FCS

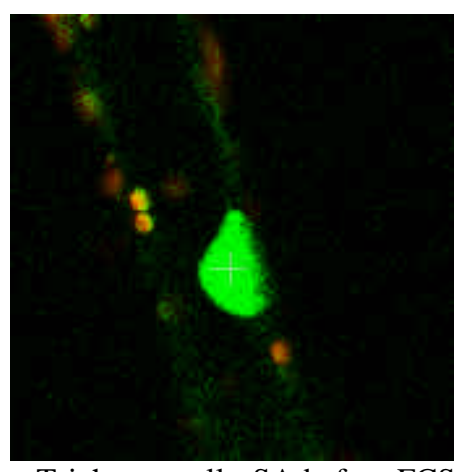

Trichoma cell + SA before FCS

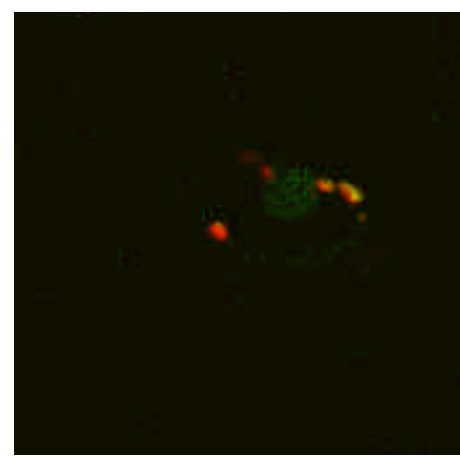

Trichoma cell -SA after FCS

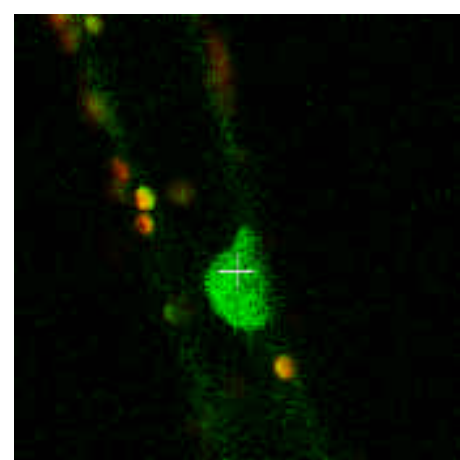

Trichoma cell + SA after FCS

Fig. 4.29. Trichoma cells expressing TGA2.1-GFP without SA (upper row) or with SA (lower row) induction and before FCS (left column) or after FCS (right column).

As seen on Fig. 4.29 the general GFP fluorescence in nuclei of both non-induced and induced samples is evenly decreasing after the FCS measurements due to photobleaching of the GFP chromophores in the nucleus by the scanning laser, indicating that the TGA2.1-GFP fusion proteins are mobile and the GFP molecules which are already 
bleached are replaced by diffusion from the FCS measurement focus with new ones and this results in an overall GFP fluorescence loss (FLIP) in the nucleus. More information about the diffusion parameters can be obtained from the curves of the autocorrelation function $\mathrm{G}(\mathrm{t})$ which are given on Fig. 4.30 after fitting the raw experimental data to model functions for 2- or 1-component free diffusion:

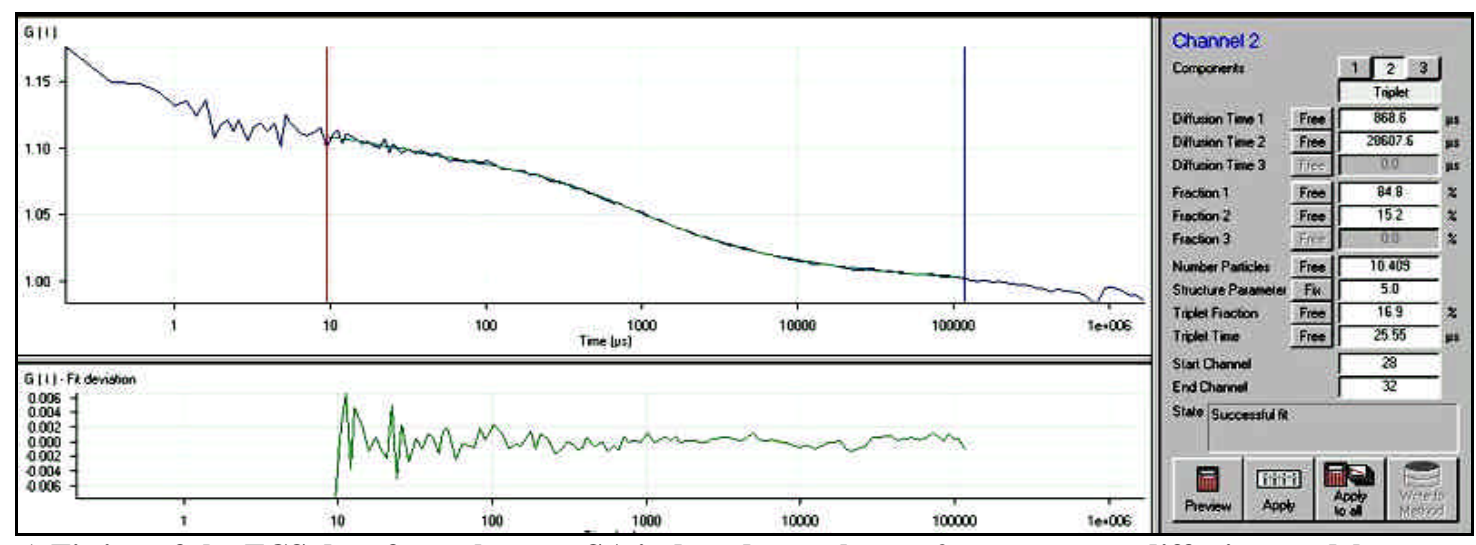

a) Fitting of the FCS date from the non-SA-induced sample to a 2-components diffusion model

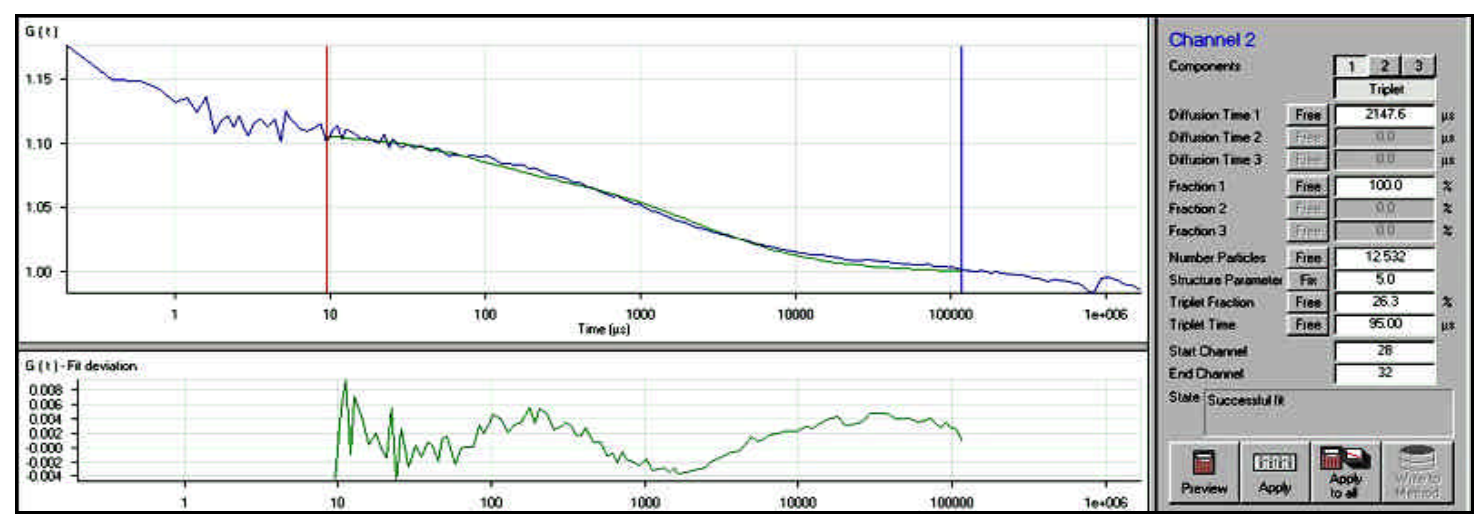

b) Fitting of the FCS date from the non-SA-induced sample to an 1-component diffusion model

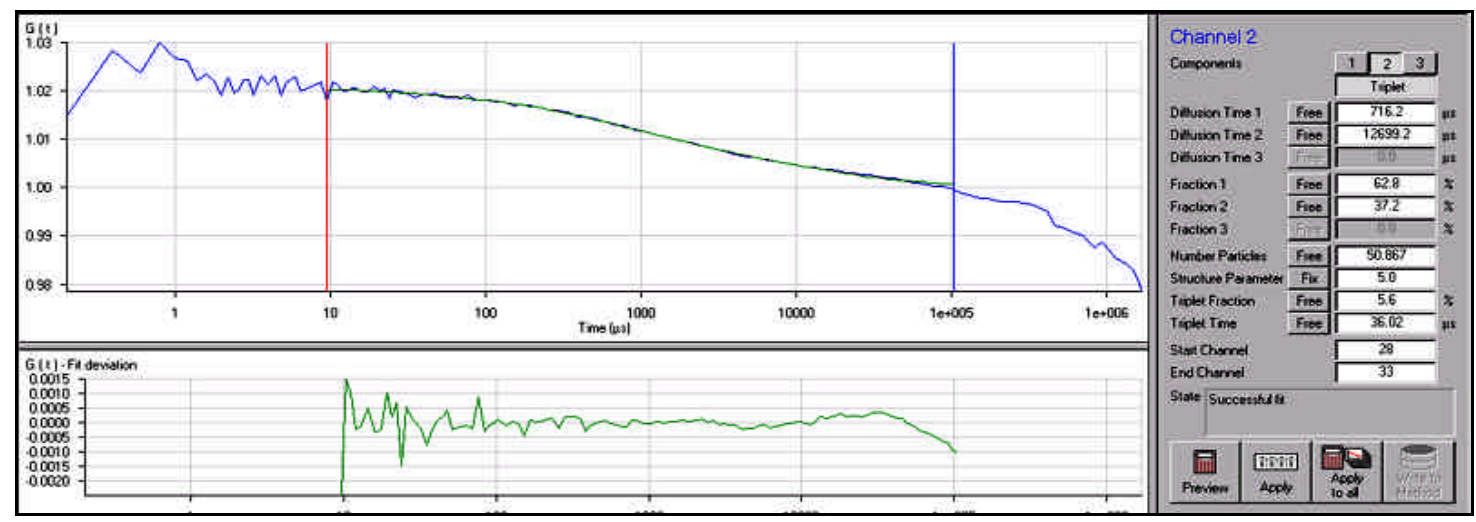

c) Fitting of the FCS date from the SA-induced sample to a 2-components diffusion model 


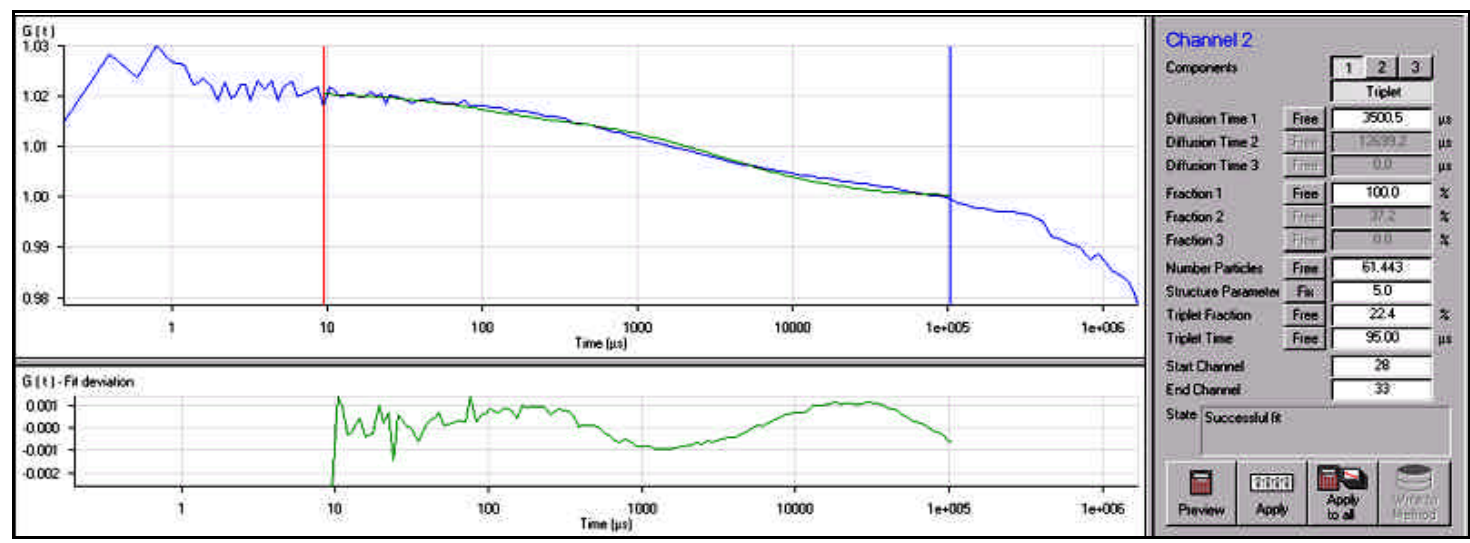

d) Fitting of the FCS date from the SA-induced sample to an 1-component diffusion model

Fig. 4.30. Autocorrelation curves, fitting deviations and fractions parameters of TGA2.1-GFP in trichoma cells

As can be seen from the deviations from an ideal 2- or 1-component diffusion fitting function (shown under each autocorrelation graphic) the experimental data from trichoma cells fits better to a model with 2 mobile fluorescent fractions present in the nucleus (Fig. $4.30 \mathrm{a} \& \mathrm{c}$ ), one of which is several times slower that the other. The ratio "slower : faster fraction" changes upon SA induction in favor of the slower one, which can be seen also by the slower decay of the autocorrelation curve of the SA-induced sample; this change can be interpreted a decreased mobility of the TGA2.1-GFP proteins due to an increased involvement in interactions with other molecules (DNA or proteins) after stimulation with SA. Still a large pool of TGA2.1-GFP molecules stays mobile even after SA induction, probably because of insufficiency of interaction partners or binding targets, a result of the high level of expression of TGA2.1-GFP fusion protein, controlled by the strong constitutive HBT promoter (Sheen, 1993).

\subsubsection{Mobility of TGA2.1-GFP in nuclei of stomata guard cells}

The LSM pictures before and after the FCS measurements of TGA2.1-GFP in nuclei of stomata guard cells are given on Fig. 4.31:

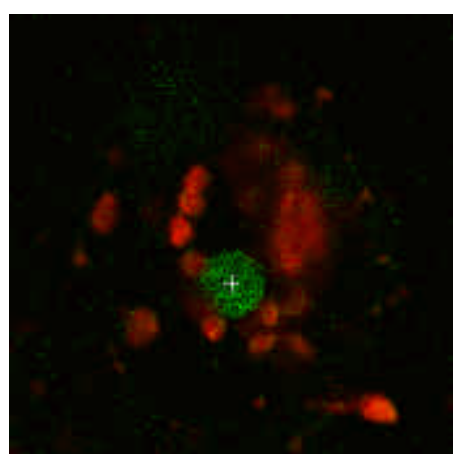

Guard cell -SA before FCS

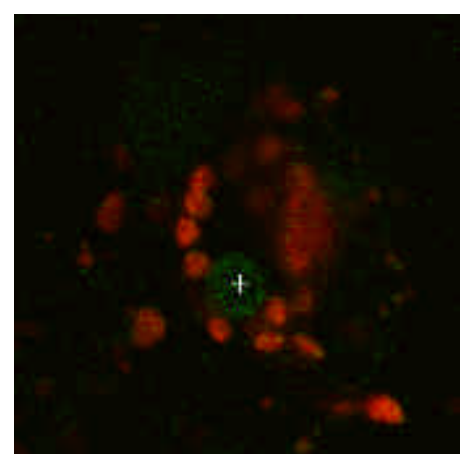

Guard cell -SA after FCS 


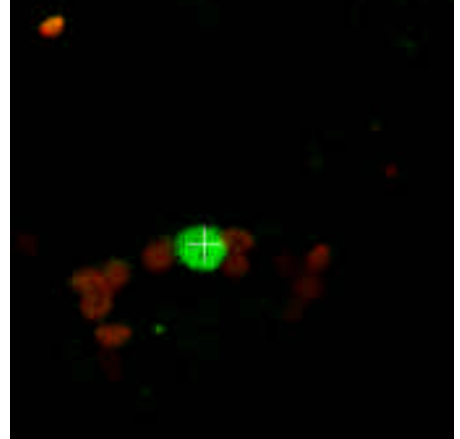

Guards cell + SA before FCS

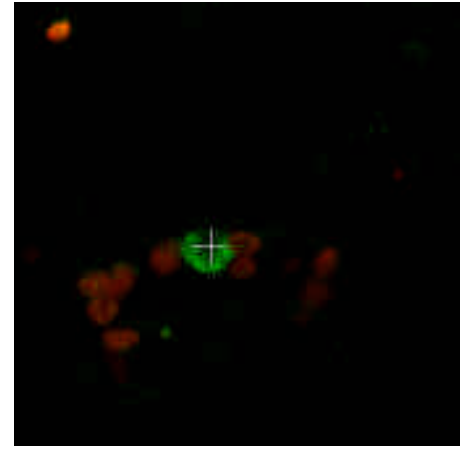

Guard cell +SA after FCS

Fig. 4.31. Stomata guard cells expressing TGA2.1-GFP without SA (upper row) or with SA (lower row) treatment and before FCS (left column) or after FCS (right column).

As can be seen on Fig. 4.31 the laser beam used for the excitation of GFP during FCS causes heterogeneous decrease of the GFP fluorescence in the nucleus - the fluorescence in the focus of the FCS measurement is bleached much more in the FCS measurement focus than the surrounding fluorescence, indicating that the fluorescent TGA2.1-GFP molecules are not leaving the illum inated focus i.e. that they are immobile.

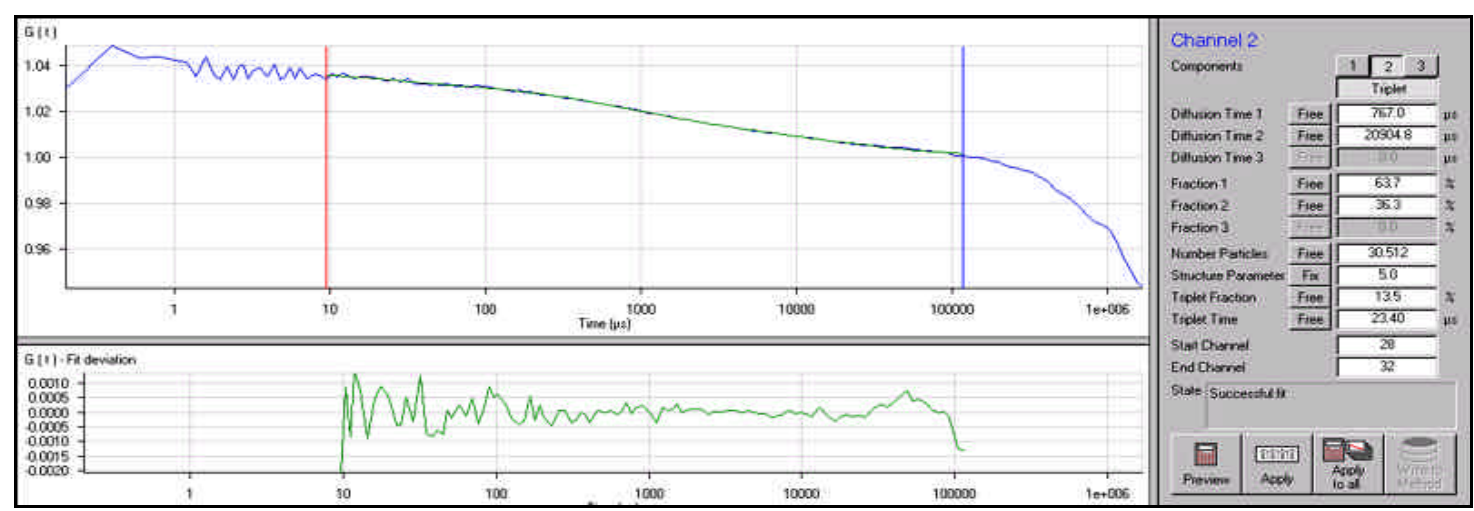

a) Fitting of the FCS date from the non-SA-induced sample to a 2-components diffusion model

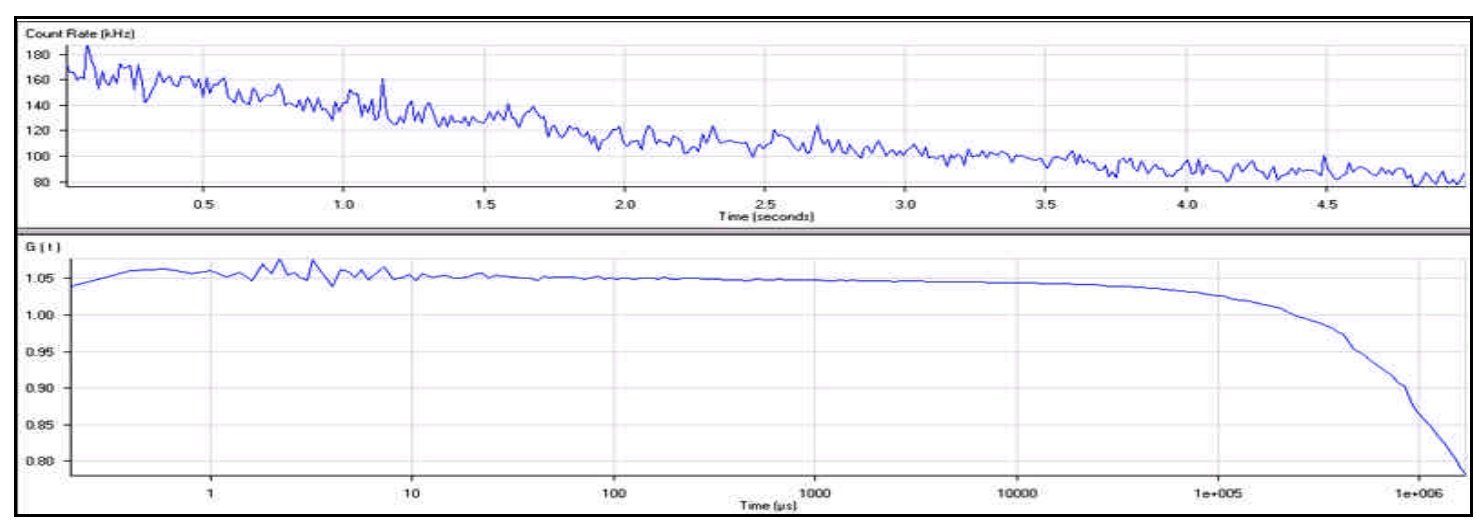

b) Count rate $(\mathrm{kHz})$ and correlation curve of the SA-induced sample

Fig. 4.32. Autocorrelation curves, fitting deviations and fractions parameters of TGA2.1-GFP in stomata guard cells 
In the case of stomata guard cells according to the curves derived from the FCS measurements already in the non-induced state about 1/3 of the TGA2.1-GFP molecules (the slower fraction, see Fig. 4.32 a) seem to participate in some kind of interactions inside the nucleus, while about $2 / 3$ of the TGA2.1-GFP molecules still seem to diffuse freely. The situation changes after SA induction - the mobile fraction is not detectable anymore (seen also from the curve of the autocorrelation function) and GFP fluorescence in the measurement spot is bleached away by the laser (Fig. $4.32 \mathrm{~b}$ upper part), indicating that the most of the fusion proteins are immobile.

\subsubsection{Mobility of TGA2.1-GFP in nuclei of epidermal cells}

The LSM pictures before and after the FCS measurements of TGA2.1-GFP in nuclei of epidermal cells are shown on Fig. 4.33:

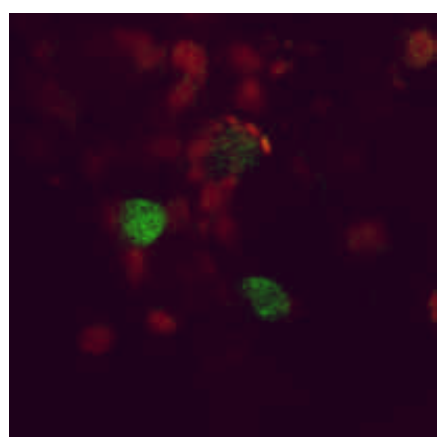

Epidermalcell -SA before FCS

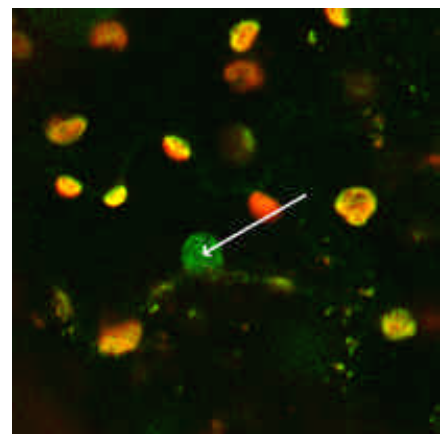

Epidermalcell +SA before FCS

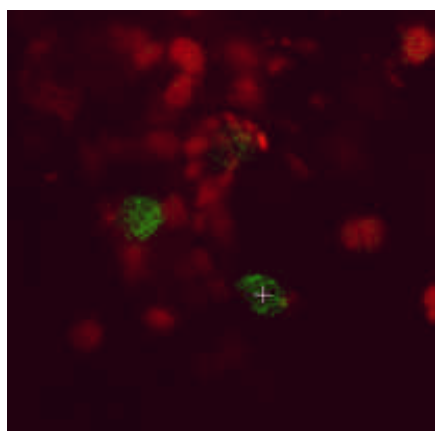

Epidermalcell -SA after FCS

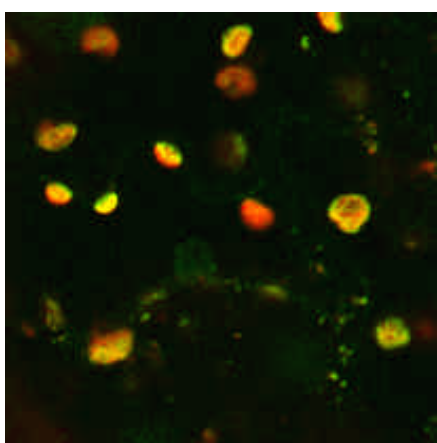

Epidermalcell + SA after FCS

Fig. 4.33. Epidermal cells expressing TGA2.1-GFP without SA (upper row) or with SA (lower row) induction and before FCS (left column) or after FCS (right column).

The mobility pattern of TGA2.1-GFP in epidermal cells differs from the one in stomata guard cells - the greater part of the fluorescent molecules are immobile without SA induction, seen as the a decrease in GFP fluorescence (FLIP) in the FCS focus (indicated with a white cross on Fig. 4.33 upper row); the results after stimulation with SA were ambiguous; the sample presented here (Fig. 4.33 lower row and its corresponding FCS 
graphic Fig 5.34 b) seems mobile on the CLSM pictures but FCS detected significant immobility; in order to clarify this controversy, further experiments will be necessary.

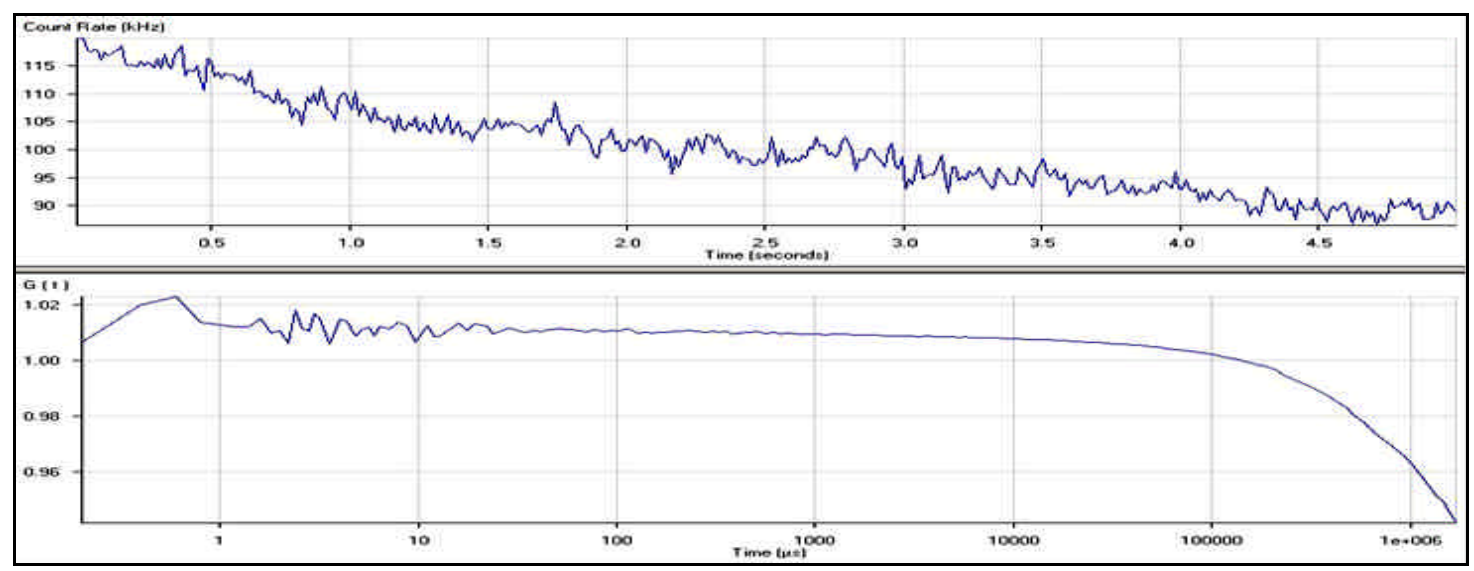

a) Count rate $(\mathrm{kHz})$ and correlation curve of the non-induced sample

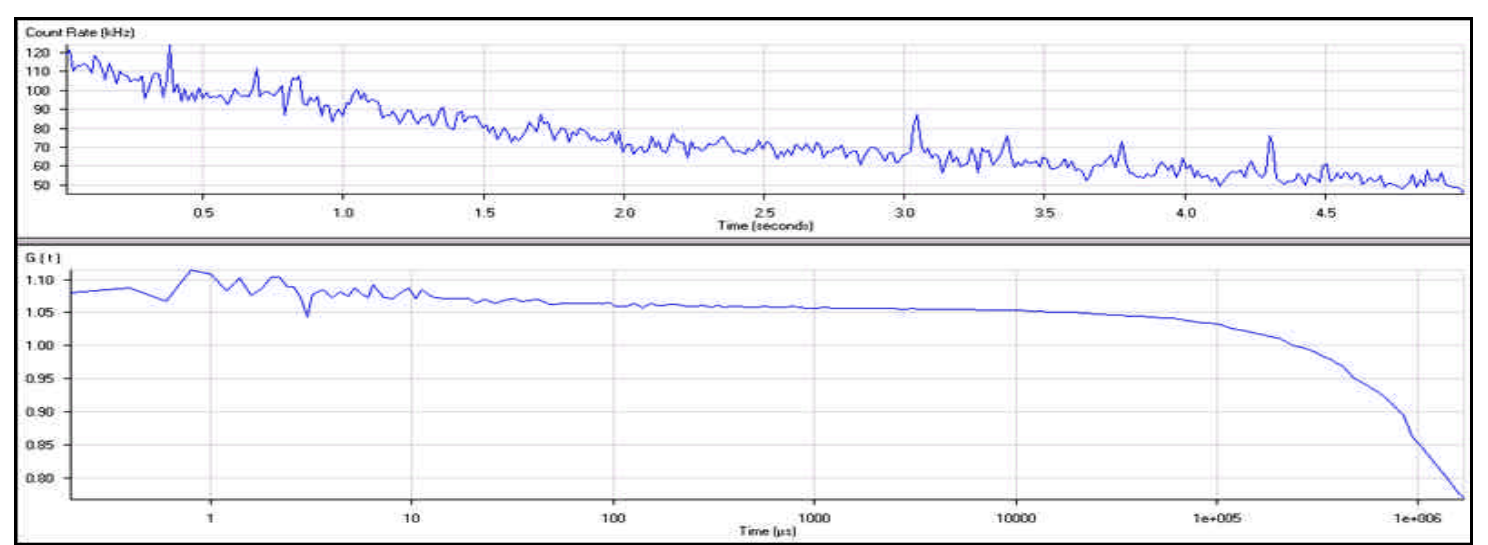

b) Count rate $(\mathrm{kHz})$ and correlation curve of the SA-induced sample

Fig. 4.34. Autocorrelation curves, fitting deviations and fractions parameters of TGA2.1-GFP in epidermal cells

Before SA induction, most of the TGA2.1-GFP fusion proteins in the nuclei of epidermal cells are immobile (Fig. 4.34 a) probably by binding to their DNA targets (the as-1element) or/and by forming higher molecular weight complexes with other proteins, etc. As mentioned above, the situation after SA induction could not be determined with certainty due to the insufficient and ambiguous data, therefore additional experiments have to be performed in order to rule out the effect of SA on the TGA2.1-GFP fusion proteins in the leaf epidermal cells.

\subsubsection{Characterization of the mobility properties of TGA2.2-GFP in nuclei of leaf cells}

Leaf tissues from TGA2.2-GFP transgenic plants that showed high GFP fluorescence in the screening for positive GFP transformants (lines \#5 and \# 16, see 4.2) were used for experiments. Leaf discs from plants grown in soil in a climate chamber were incubated in 
phosphate buffer pH 5.8 without or with $1 \mathrm{mM} \mathrm{SA}$, tissue was peeled off from the lower surface of the leaf with sharp pincers, embedded in an agarose drop on a microscopic slide, covered and mounted on the microscope. After visualization of the TGA2.2-GFP fusion proteins with CLSM, FCS measurements were performed.

\subsubsection{Mobility of TGA2.2-GFP in nuclei of trichoma cells}

The LSM pictures of the FCS studies of TGA2.2-GFP in nuclei of trichoma cells are presented on Fig. 4.35:

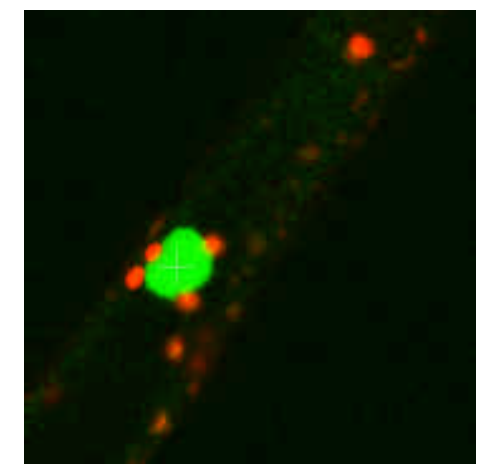

Trichoma cell -SA before FCS

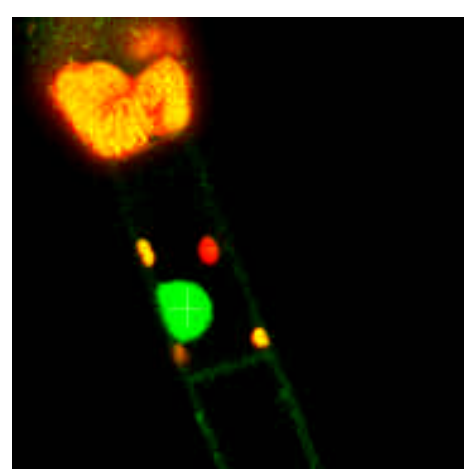

Trichoma cell + SA before FCS

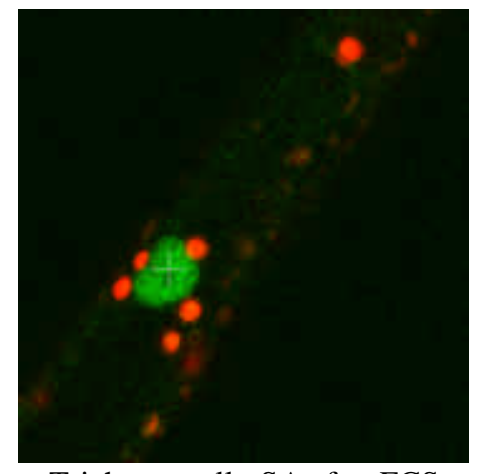

Trichoma cell -SA after FCS

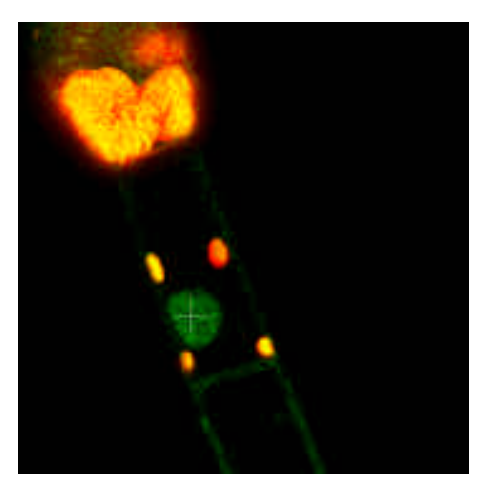

Trichoma cell +SA after FCS

Fig. 4.35. Trichoma cells expressing TGA2.2-GFP without SA (upper row) or with SA (lower row) induction and before FCS (left column) or after FCS (right column).

The overall GFP fluorescence in nuclei of both non-induced and induced trichoma cells is decreasing after FCS measurements due to photobleaching of the GFP chromophores; still in the non-induced state the region of the FCS focus bleaches somehow stronger than the surrounding fluorescence, suggesting in this case some mixture of mobile and immobile fluorescent TGA2.2-GFP particles, while in the induced sample the bleaching is quite homogeneous meaning that in trichoma cells most fluorescent TGA2.2-GFP molecules become mobile upon induction with SA. 


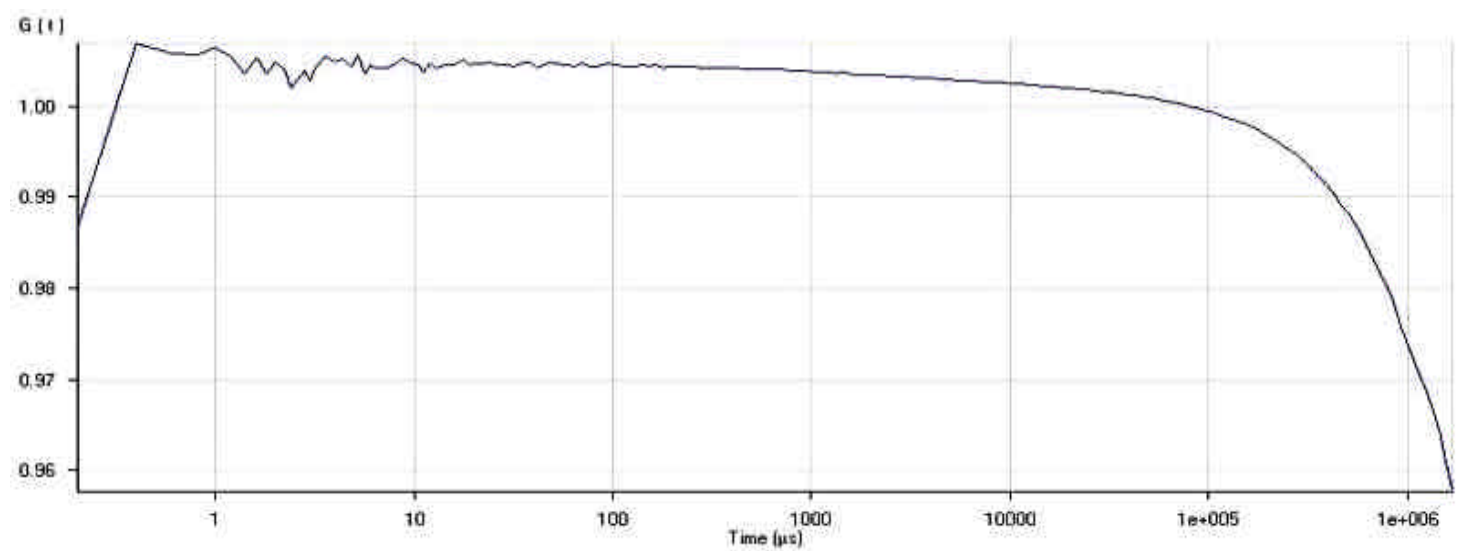

a) Autocorrelation curve derived from the non-SA-induced sample

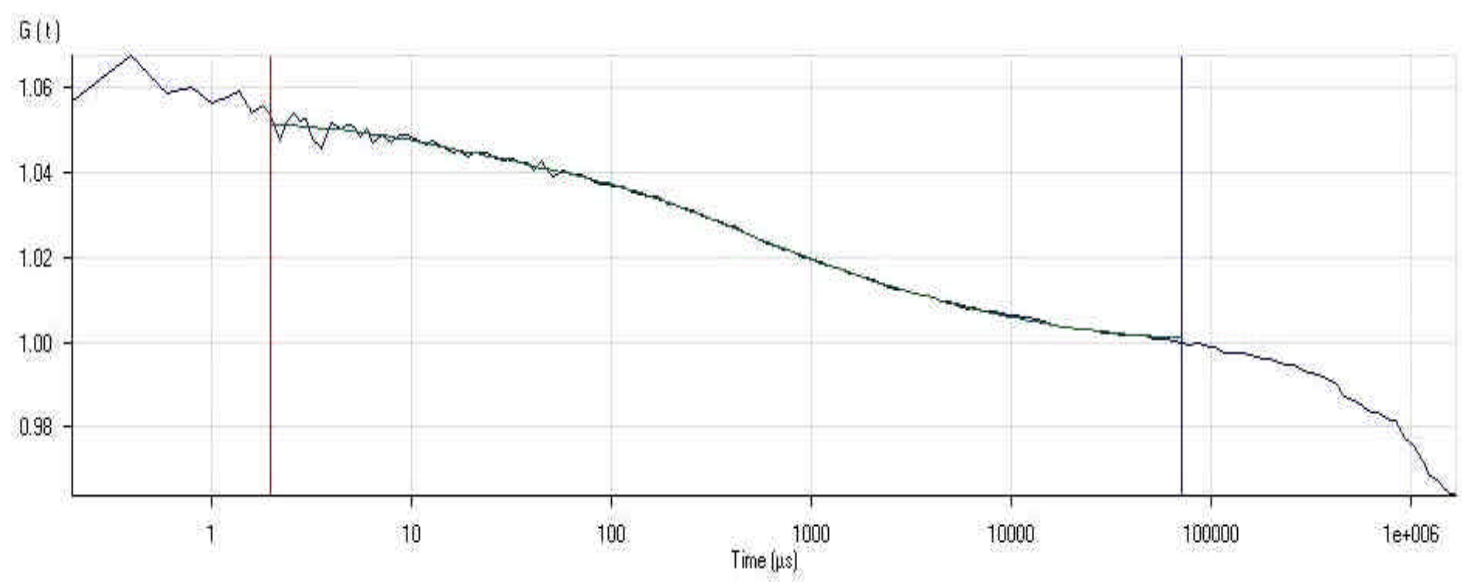

b) Autocorrelation curve derived from the SA-induced sample

Fig. 4.36. Autocorrelation curves of TGA2.2 -GFP in trichoma cells

The ACF curve of the non-induced sample show a prevalence of immobile particles in the point of measurements possibly because of some kind of interactions of TGA2.2-GFP with other nuclear components; after the stimulation with SA most of the fluorescent particles become mobile as can be seen from the slope of the ACF curve and that suggests that those interactions might have been abolished in trichoma cells after SA has been applied.

\subsubsection{Mobility of TGA2.2-GFP in nuclei of stomata guard cells}

The LSM pictures of the FCS measurements of TGA2.2-GFP in nuclei of stomata guard cells are given on Fig. 4.37: 


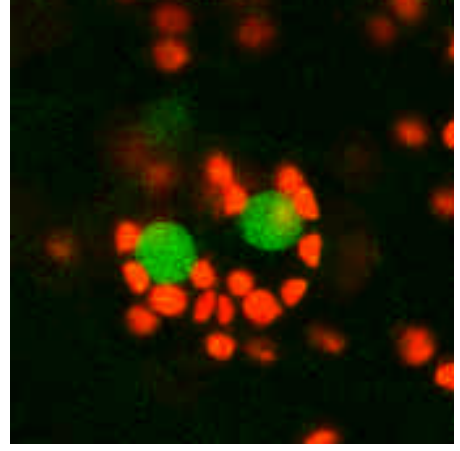

Guard cells -SA before FCS

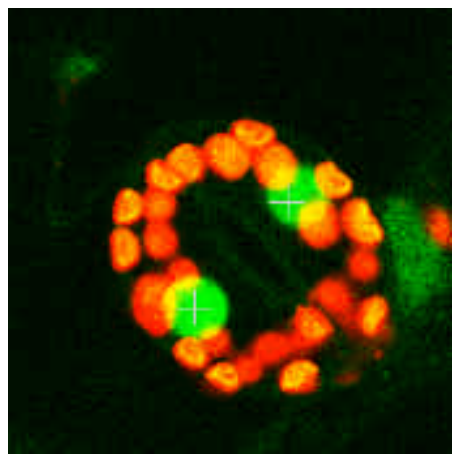

Guard cells + SA before FCS

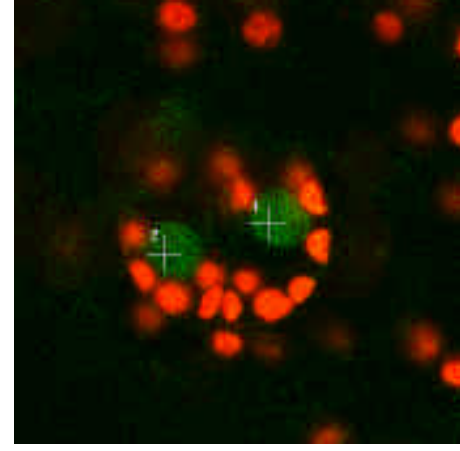

Guard cells -SA after FCS

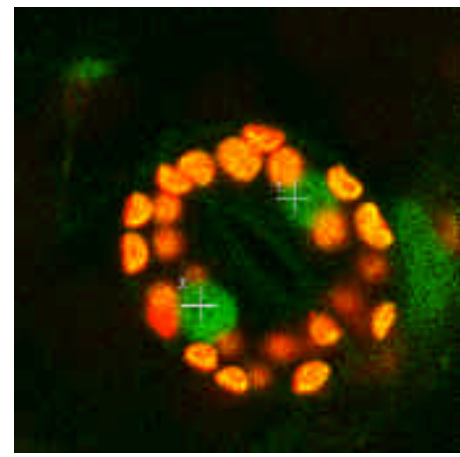

Guard cells + SA after FCS

Fig. 4.37. Stomata guard cells expressing TGA2.2-GFP without SA (upper row) or with SA (lower row) treatment and before FCS (left column) or after FCS (right column).

As can be seen on Fig. 4.37 in nuclei of stomata guard cells the TGA2.2-GFP fusion proteins seem to be mobile with or without SA induction, according to the overall decrease of nuclear GFP fluorescence, a result of photobleaching (from the laser light during the FCS measurements) of the GFP chromophores in the focus and their replacement with new ones by diffusion. The mobility parameters of TGA2.2-GFP in nuclei of stomata guard cell can be figured out from the autocorrelation curves (Fig. 4.38)

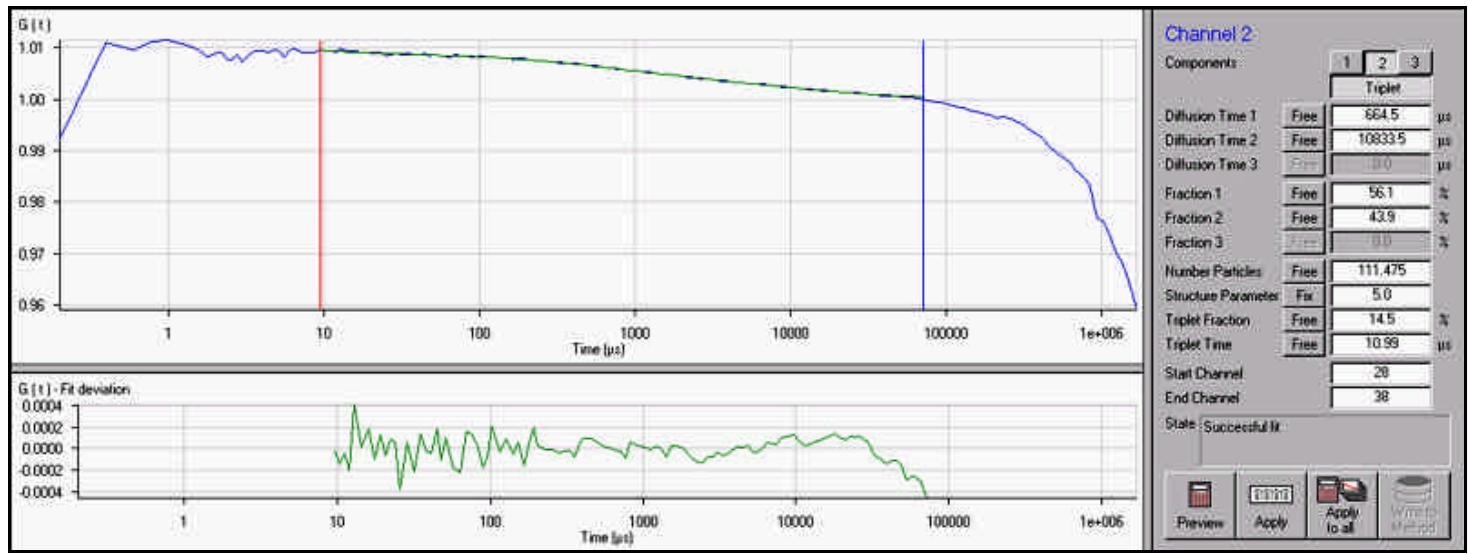

a) Fitting of the FCS date from the non-SA-induced sample to a 2-components diffusion model 


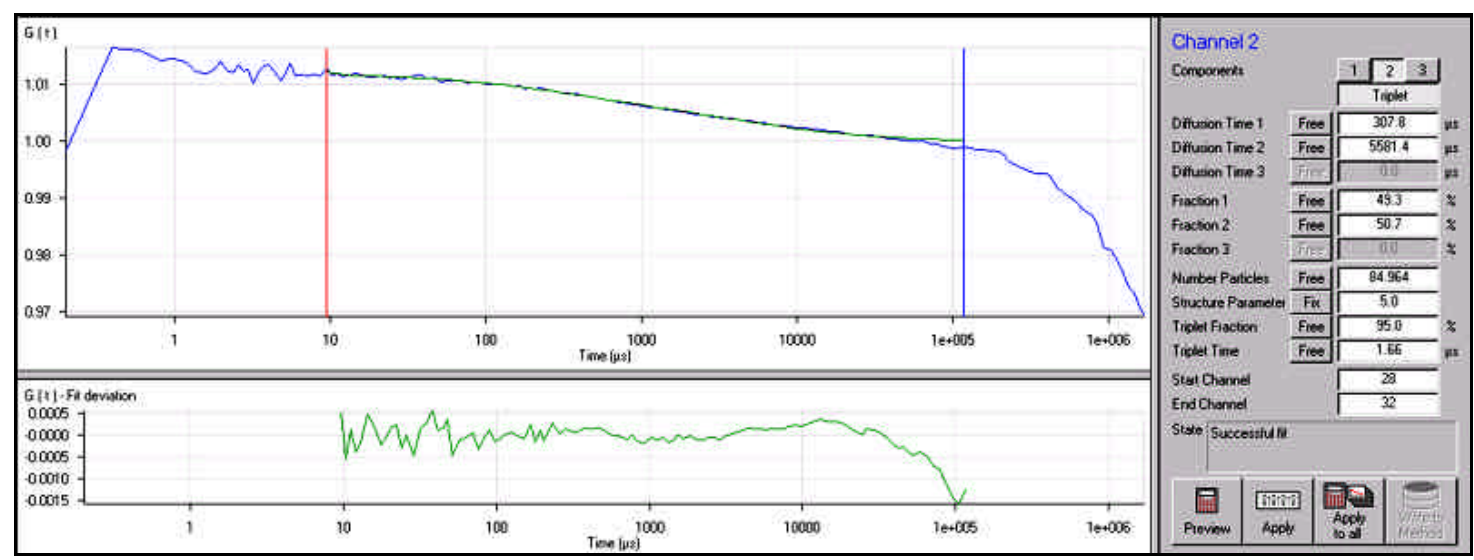

b) Fitting of the FCS date from the SA-induced sample to a 2 -components diffusion model

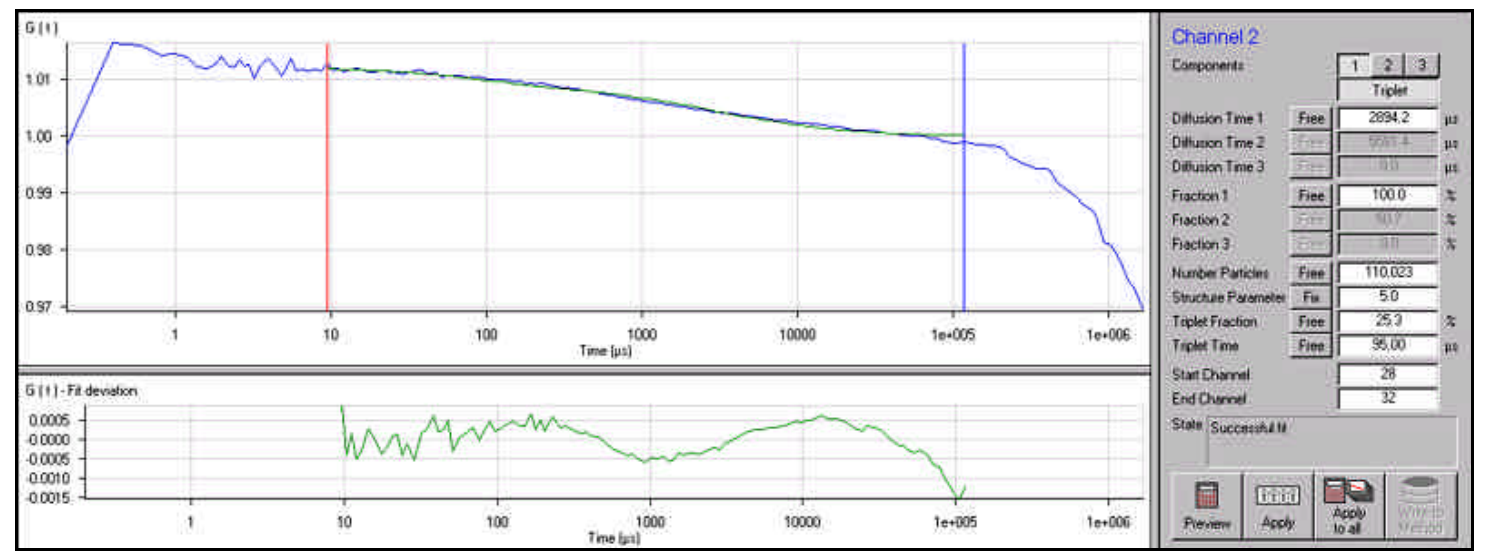

c) Fitting of the FCS date from the SA-induced sample to an 1-component diffusion model

Fig. 4.38. Autocorrelation curves, fitting deviations and fractions parameters of TGA2.2-GFP in stomata guard cells

The data from stomata guard cells fits much better to a model with 2 mobile fluorescent fractions present in the nucleus (Fig. $4.38 \mathrm{a} \&$ b) than only to 1-component diffusion (Fig. $4.38 \mathrm{c}$ ); one of the two components is about 10 times slower than the other; the ratio "slower : faster" component in nuclei of stomata guard cells without or with SA stays similar (approx. $45 \%: 55 \%$ ), indicating no change of the mobility of TGA2.2-GFP fusion proteins after SA treatment.

\subsubsection{Mobility of TGA2.2-GFP in nuclei of epidermal cells}

The LSM pictures of the FCS measurements of TGA2.2-GFP in nuclei of epidermal cells are given on Fig. 4.39: 


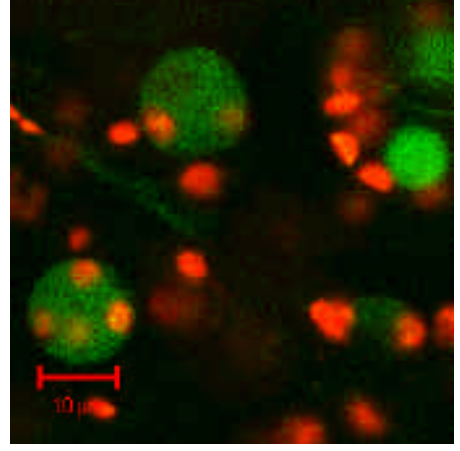

Epidermal cell -SA before FCS

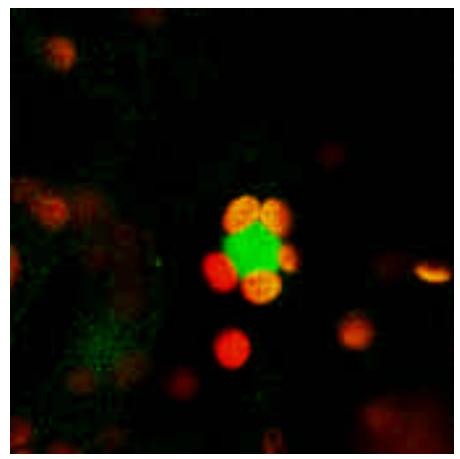

Epidermal cell +SA before FCS

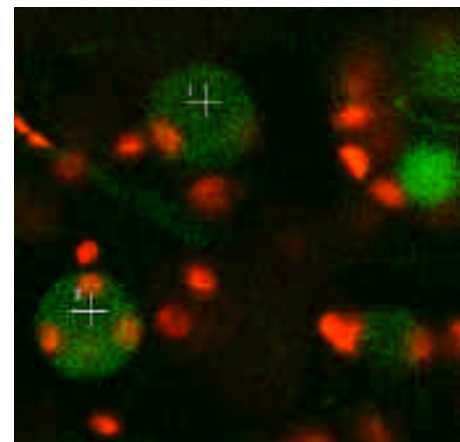

Epidermal cell -SA after FCS

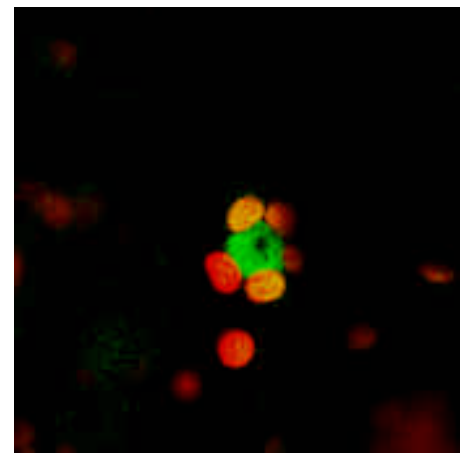

Epidermal cell + SA after FCS

Fig. 4.39. Epidermal cells expressing TGA2.2-GFP without SA (upper row) or with SA (lower row) treat ment and before FCS (left column) or after FCS (right column).

In non-induced epidermal cells the overall decrease of GFP fluorescence in the nucleus is not so obvious, there seems to be a mixture or an equilibrium of mobile and immobile fluorescent particles (see also the autocorrelation curve, Fig. 4.39 a). After SA treatment it was very clear that most of the TGA2.2-GFP had become immobile and the focused laser light bleached holes in the GFP fluorescence at the point of measurements (Fig. 4.39 lower row); this immobility was also detected in the FCS experiments (Fig. 4.40 b)

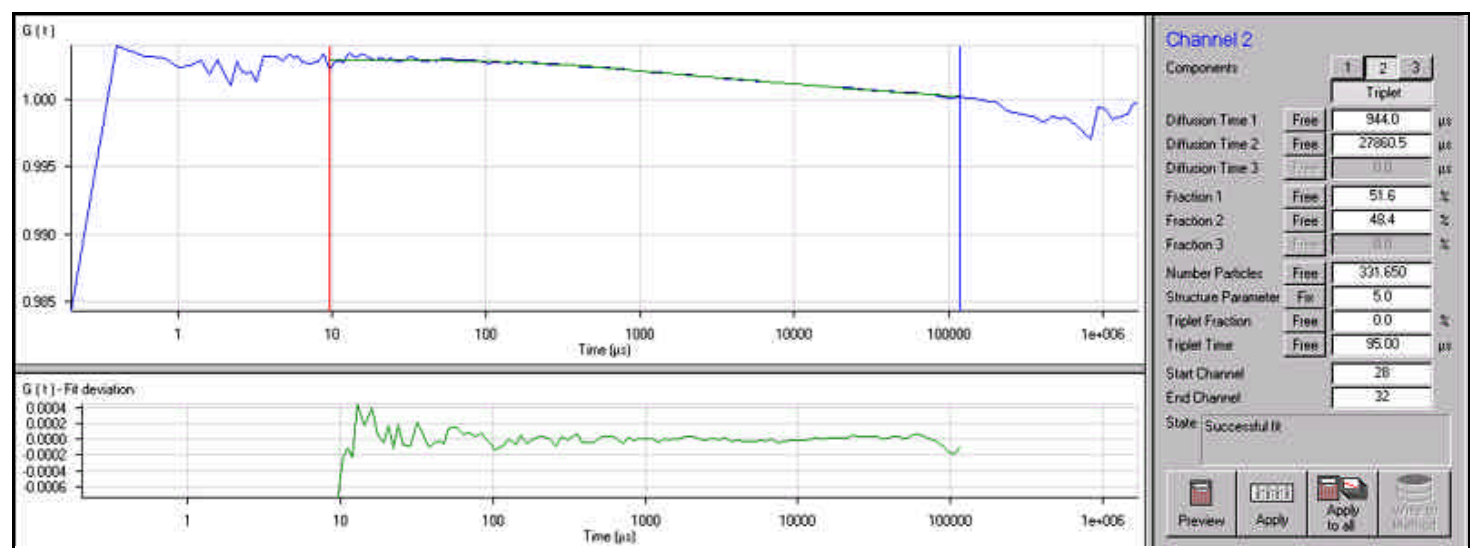

a) Fitting of the FCS date from the non-SA-induced sample to a 2-components diffusion model 


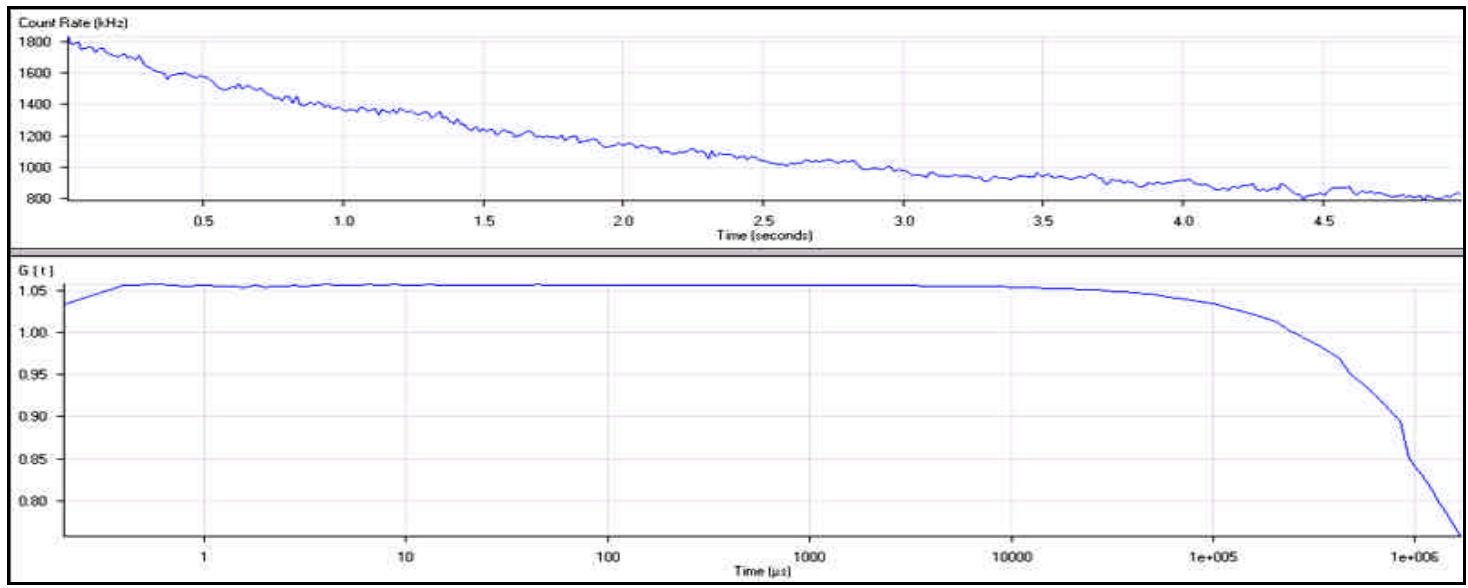

b) Count rate $(\mathrm{kHz})$ and correlation curve of the SA-induced sample

Fig. 4.40. Autocorrelation curves, fitting deviations and fractions parameters of TGA2.2-GFP in epidermal cells

In nuclei of epidermal cells without SA stimulation two mobile fluorescent components were detectable, one of which was about 20 times slower than the other; both components were present in the nuclei in more or less equal proportions. After SA induction no autocorrelation analysis could be performed because almost all GFP fluorescent particles in the FCS focus had become immobile, probably because of interactions with DNA or/and proteins.

\subsubsection{Characterization of the mobility properties of TGAla-GFP in nuclei of leaf cells}

The mobility studies of the TGA1a-GFP fusion protein were performed with leaf surface tissues from the TGA1a-GFP tobacco transgenic line \#19 (see 4.2), grown in soil in a climate chamber at $22^{\circ} \mathrm{C}$ and a light / darkness cycle of $16 / 8$ hours. Samples were prepared as described in 3.9.3 with and without SA induction to rule out the effect of SA on the mobility parameters of the GFP-tagged TGA1a in leaf nuclei.

\subsubsection{Mobility of the TGAla-GFP in trichoma cells}

The LSM pictures of the FCS measurements with trichoma cells from TGA1a-GFP \#19 leaves are presented of Fig. 4.41: 


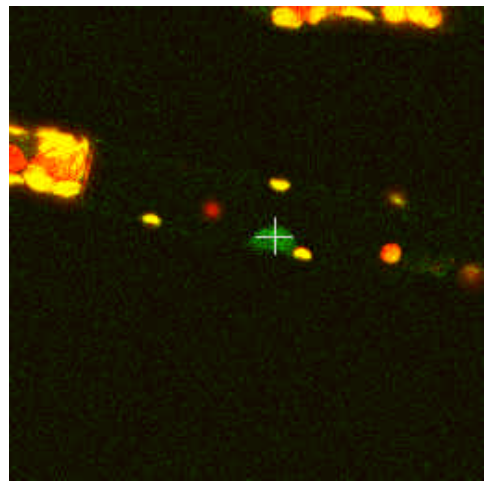

Trichoma cell-SA before FCS

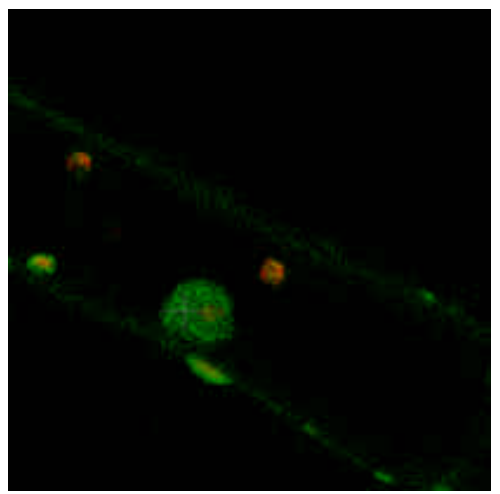

Trichoma cell + SA before FCS

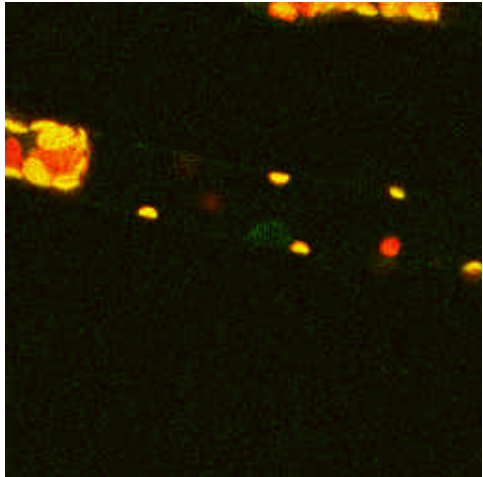

Trichoma cell -SA after FCS

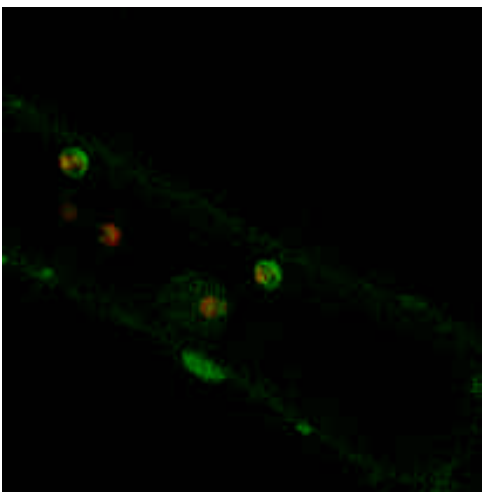

Trichoma cell + SA after FCS

Fig. 4.41. Trichoma cells from TGA1a-GFP without or with SA induction and before or after FCS

As can be seen on Fig. 4.41 the overall GFP fluorescence in the nuclei of both noninduced and induced samples is decreasing after FCS due to photobleaching of the most GFP chromophores present in the nucleus by the scanning laser; this indicates that the TGA1a-GFP fusion proteins are mobile and the already-bleached molecules are easily replaced from the measurement focus with new ones by diffusion. More information about the diffusion parameters can be obtained from the graphics of the autocorrelation function fitted to model equations for 2- or 1-component free diffusion (Fig. 4.42):

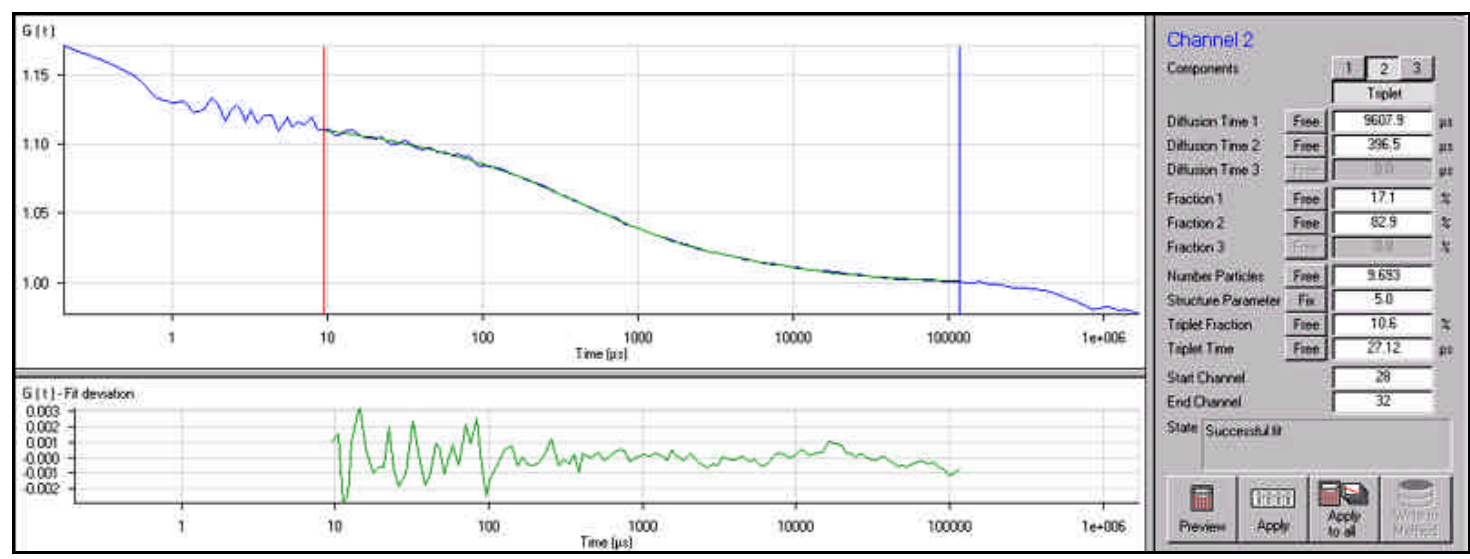

a) Fitting of the FCS date from the non -SA-induced sample to a 2-components diffusion model 


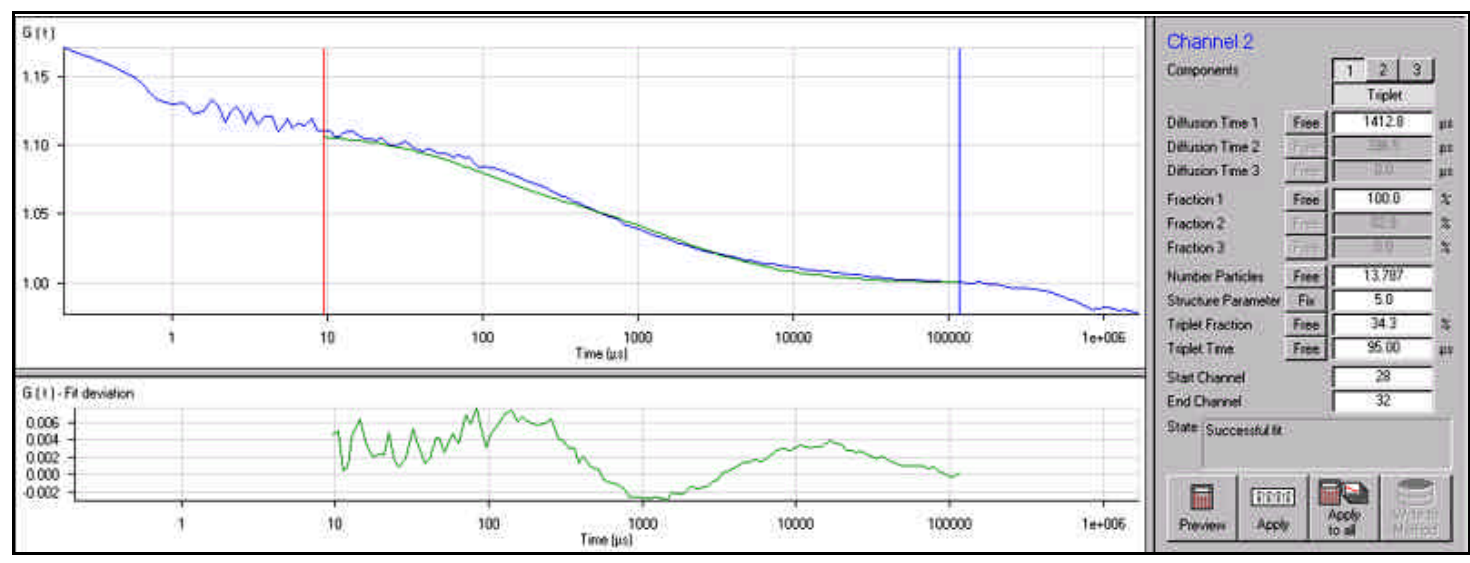

b) Fitting of the FCS date from the non-SA-induced sample to a 1-component diffusion model

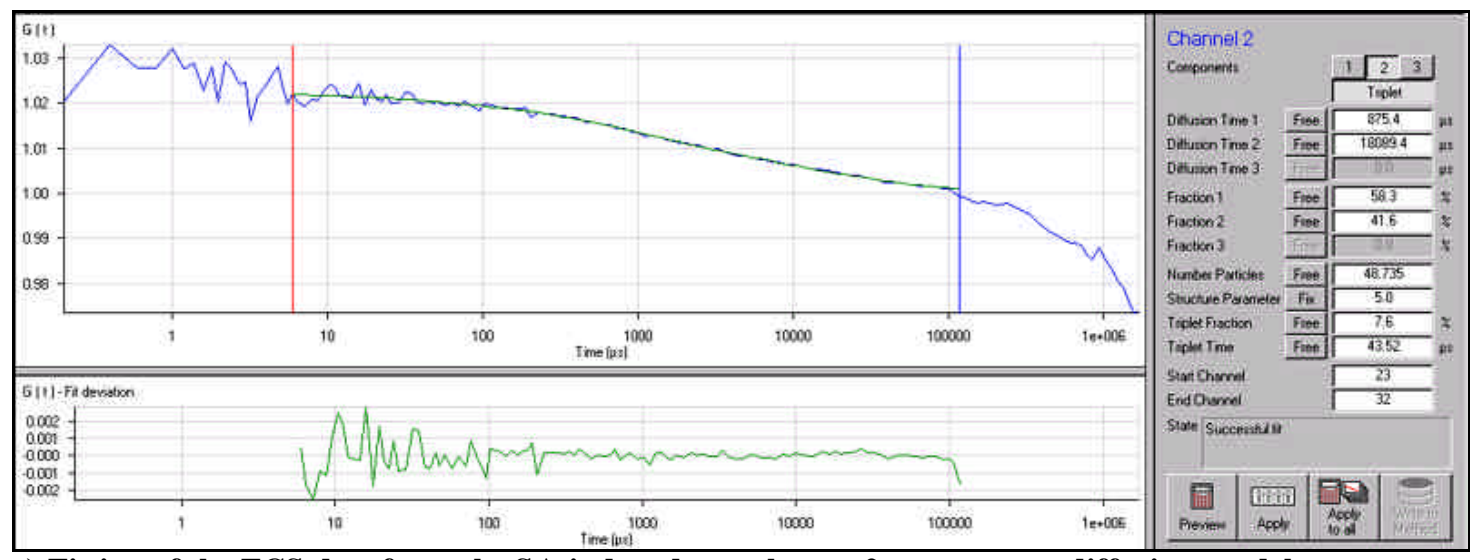

c) Fitting of the FCS date from the SA-induced sample to a 2-components diffusion model

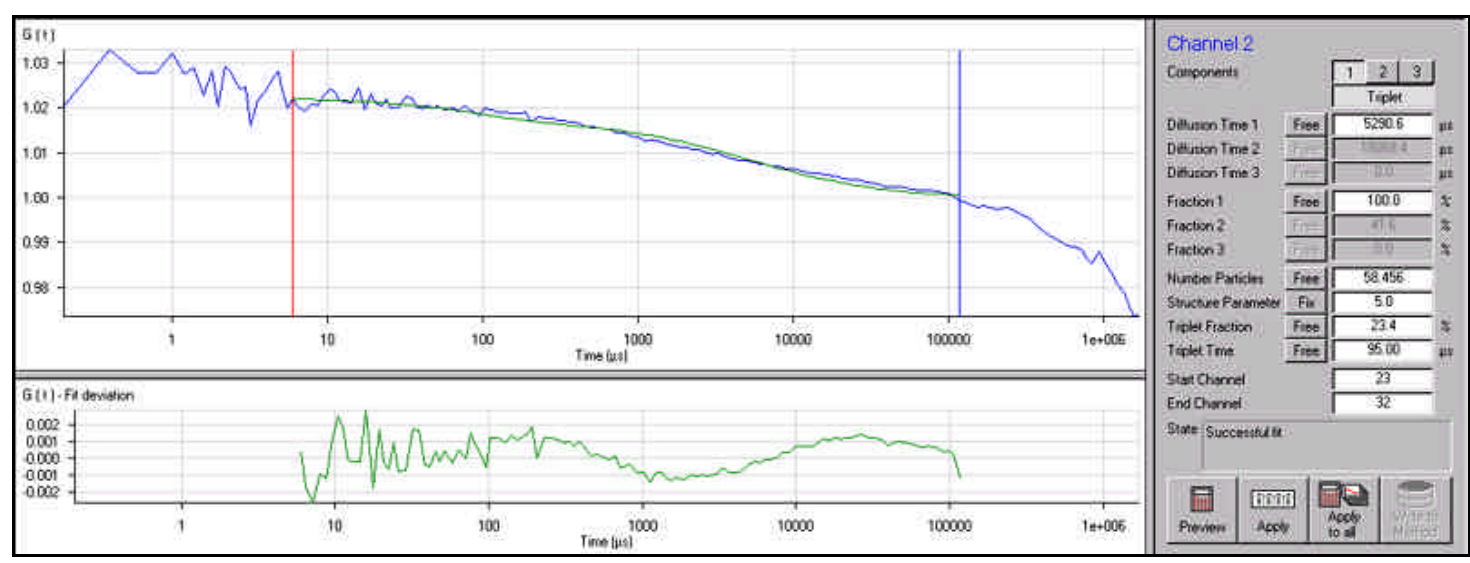

d) Fitting of the FCS date from the SA-induced sample to an 1-component diffusion model

Fig. 4.42. Autocorrelation curves, fitting deviations and fractions parameters of TGA1aGFP in trichoma cells 
As can be seen from the deviations from an ideal fitting function (shown under each autocorrelation graphic) the experimental data from trichoma cells fits better to a model that presumes 2 mobile fluorescent fractions (Fig. $4.42 \mathrm{a} \& \mathrm{c}$ ) present in the nucleus, one of which is about 3 times slower that the other. The ratio "slower : faster fraction" seems to change upon SA induction in favor of the slower one $(17.1 \%: 82.9 \%$ without SA treatment and $41.6 \%: 58.3 \%$ after SA induction) which can be interpreted as an increased involvement of the TGA1a-GFP proteins in interactions with other molecules (DNA or proteins) after stimulation with SA; still a large amount of TGA1a-GFP molecules stays mobile, probably because of insufficiency of interaction partners or lack of free as -1 targets, which is a result of the over-expression of TGAla-GFP, controlled by the constitutive HBT promoter.

\subsubsection{Mobility of TGAla-GFP in stomata guard cells}

The LSM pictures of the FCS measurements with TGA1a-GFP in nuclei of stomata guard cells are given in Fig. 4.43:

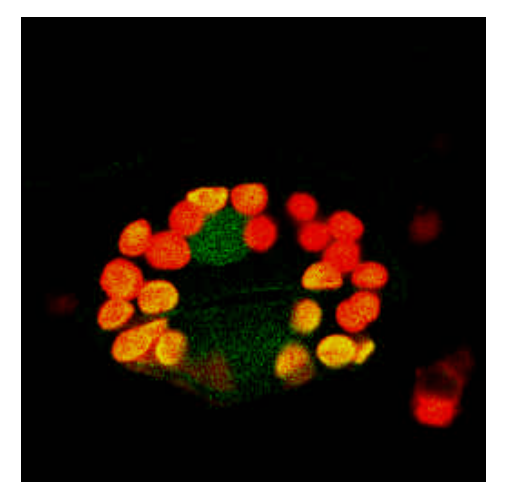

Guard cells -SA before FCS

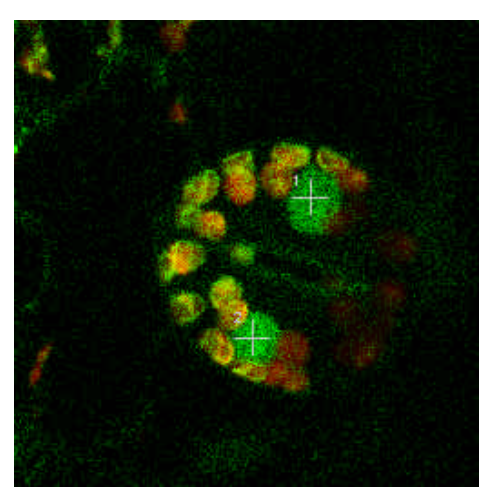

Guard cells +SA before FCS

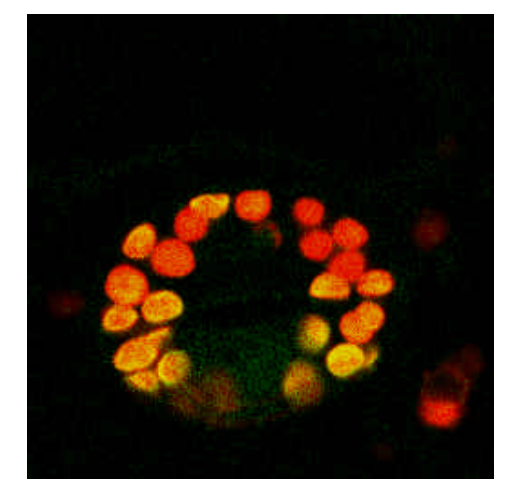

Guard cells-SA after FCS

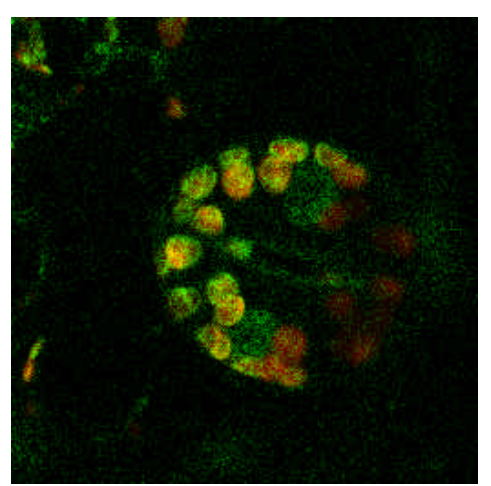

Guard cells + SA after FCS

Fig. 4.43. Stomata guard cells expressing TGA1a-GFP without or with $\mathrm{SA}$ induction and before or after FCS

The total GFP fluorescence in the nuclei of both non-induced and induced stomata guard cells is decreasing after FCS due to photobleaching of the GFP chromophores; indicating 
that the TGA1a-GFP fusion proteins are mobile and non-bleached molecules replace the already-bleached ones from the FCS focus.

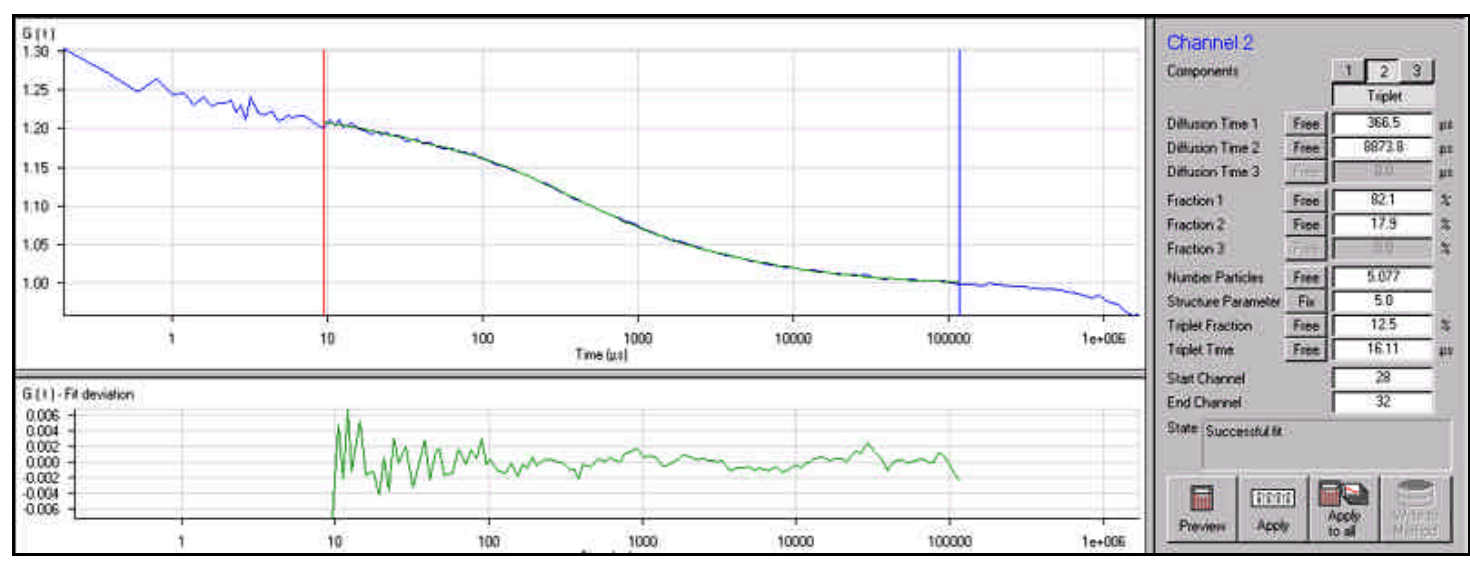

a) Fitting of the FCS date from the non -SA-induced sample to a 2-compo nents diffusion model

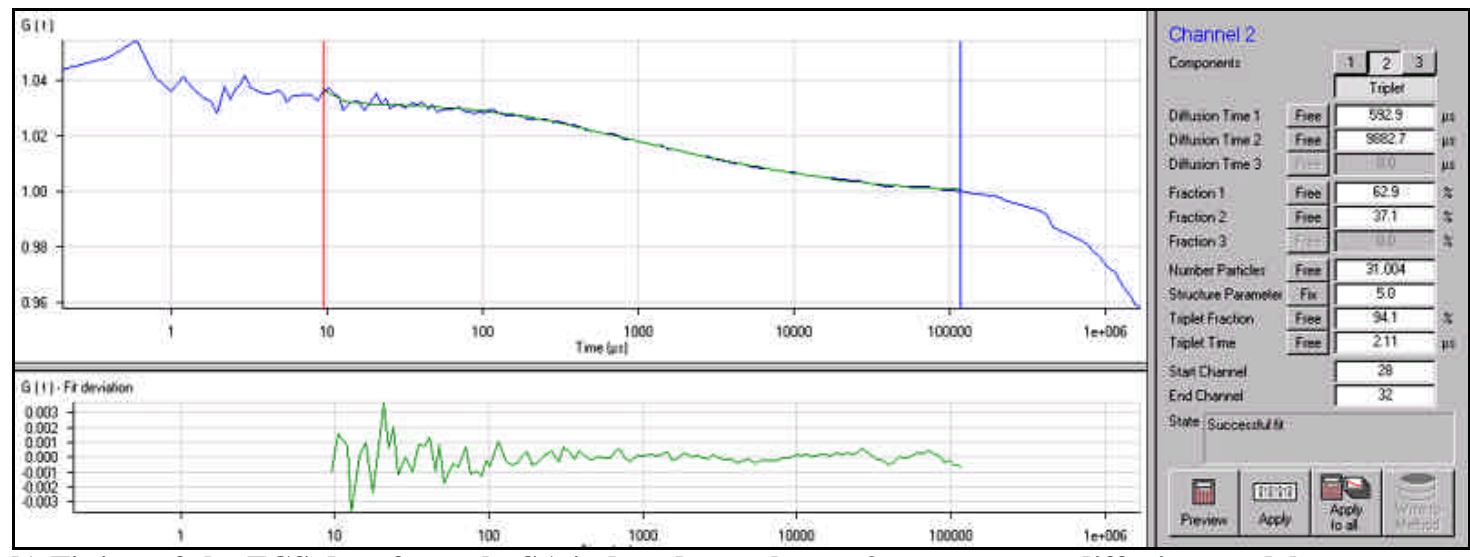

b) Fitting of the FCS date from the SA-induced sample to a 2 -components diffusion model

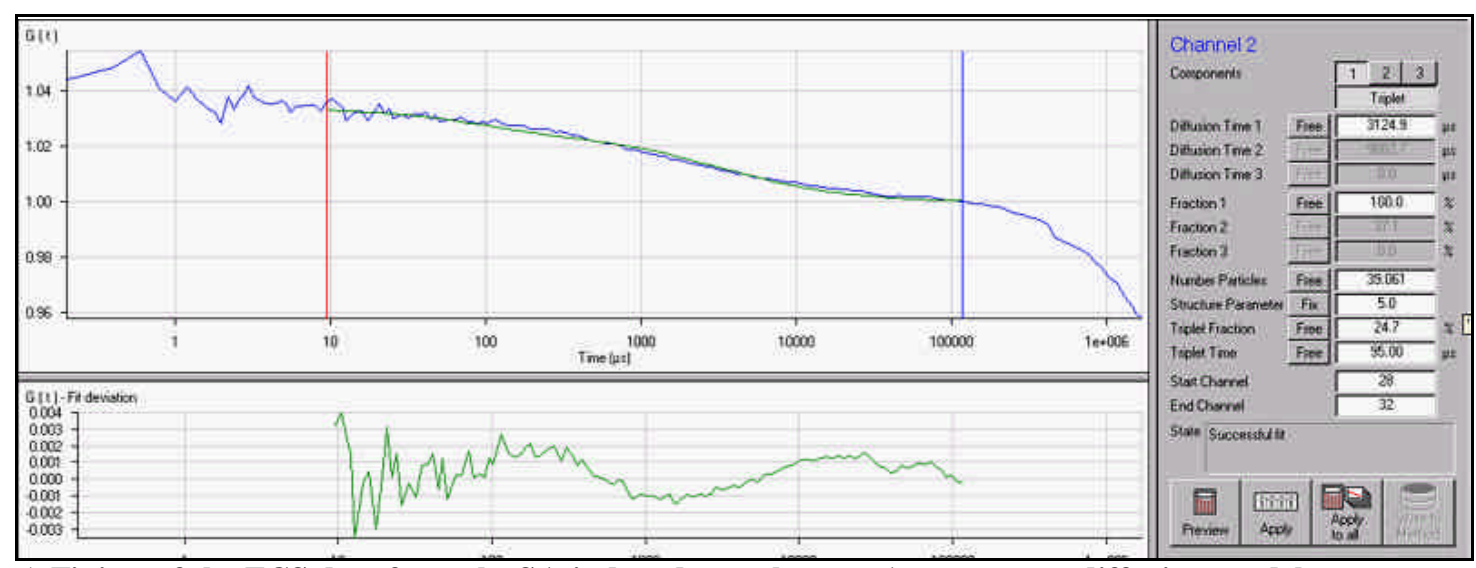

c) Fitting of the FCS date from the SA-induced sample to an 1-component diffusion model

Fig. 4.44. Autocorrelation curves, fitting deviations and fractions parameters of TGA1aGFP in stomata guard cells 
The 2-components diffusion model (Fig. $4.44 \mathrm{a} \&$ b) again seems to be a better fit for the experimental data obtained from the FCS measurements compared to an 1-component fitting (Fig. $4.44 \mathrm{c}$ ); there seem to be two mobility fractions in the nucleus, of which the slower one has about 2 times slower diffusion rate compared to the faster one. The "slower : faster" fraction ratio again changes after SA treatment (17.9\%:82.1\% in nonSA-induced cells up to $37.1 \%: 62.9 \%$ after stimulation with SA) suggesting again that the number of TGA1a-GFP proteins taking part in intermolecular interactions is increasing after the SA-signaling cascade is activated by the exogenously-applied SA.

\subsubsection{Mobility of TGA1a-GFP fusion proteins in epidermal cells}

The LSM pictures of the FCS measurements with TGA1a-GFP in nuclei of epidermal cells are given in Fig. 4.45:

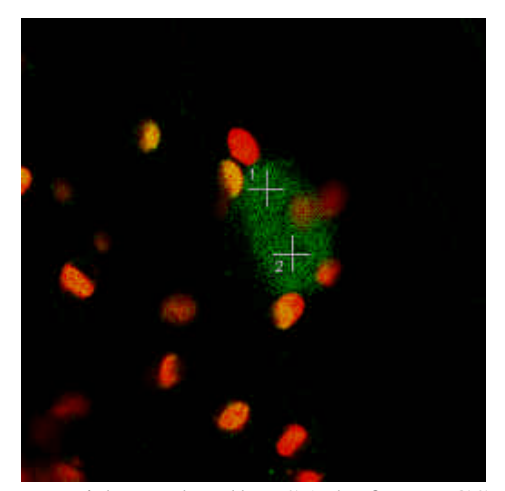

Epidermal cells -SA before FCS

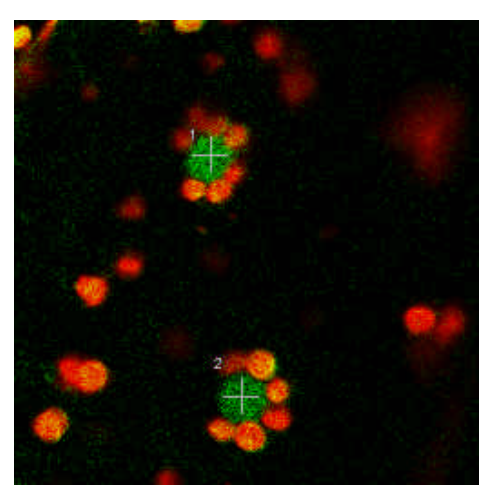

Epidermal cells + SA before FCS

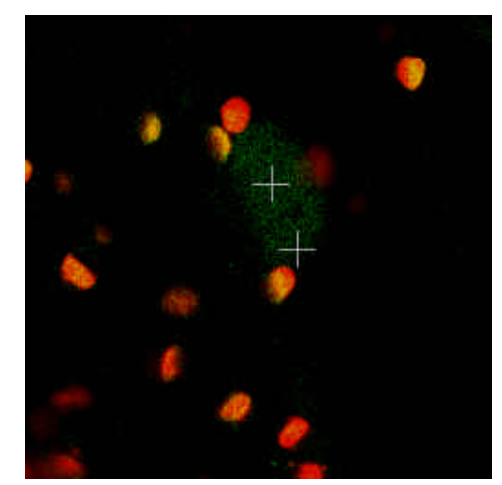

Epidermal cells -SA after FCS

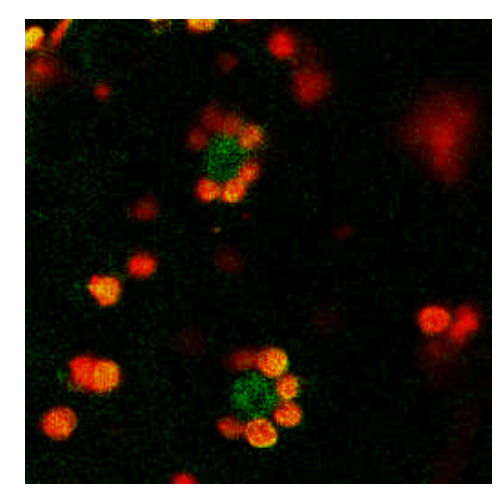

Epidermal cells + SA after FCS

Fig. 4.45. Epidermal cells from TGA1a-GFP without or with SA induction and before or after FCS

Once more the total GFP fluorescence in the nuclei is decreasing after the FCS measurements, an indication that in epidermal cells without or with SA treatment TGA1a-GFP fusion proteins are also mostly mobile and the whole fluorescent pool of molecules is bleached by the laser when they pass through the focus. 


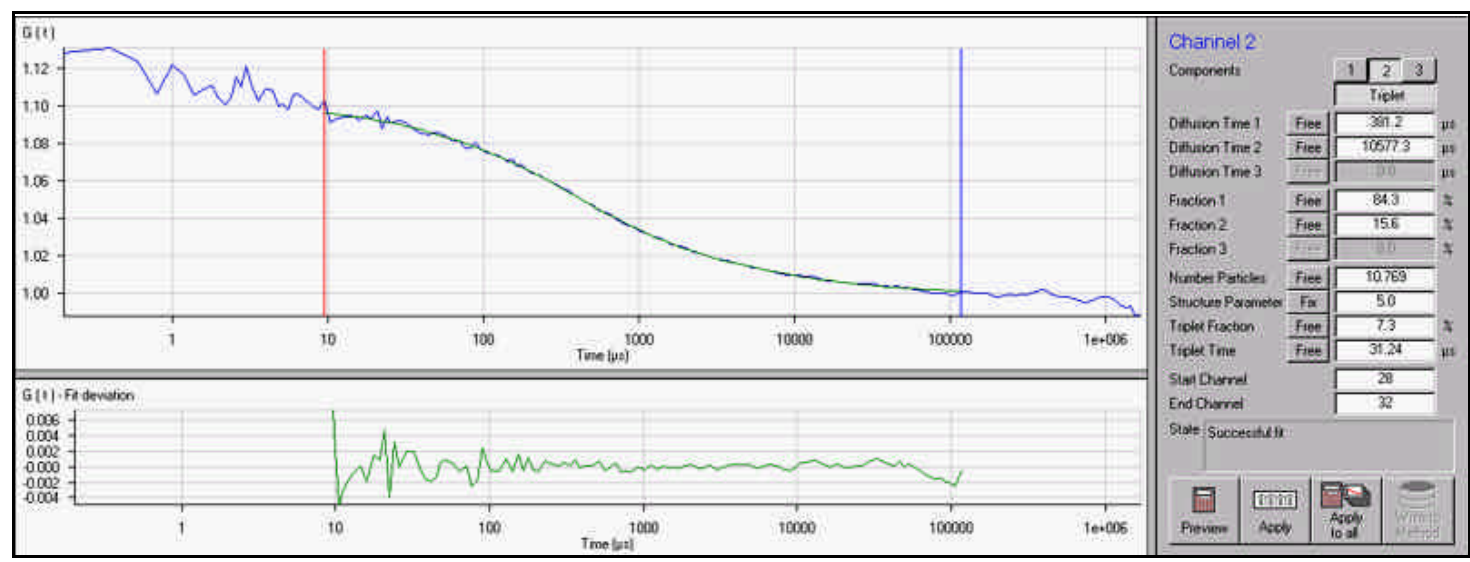

a) Fitting of the FCS date from the non -SA-induced sample to a 2-components diffusion model

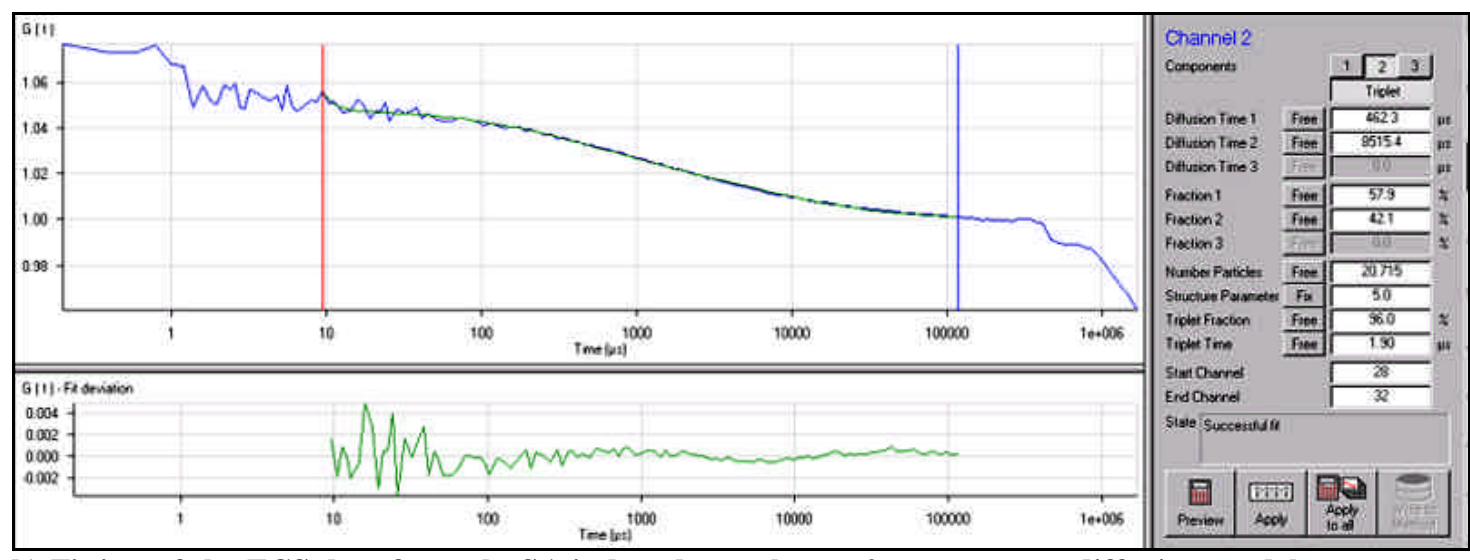

b) Fitting of the FCS date from the SA-induced sample to a 2 -components diffusion model

Fig. 4.46. Autocorrelation curves, fitting deviations and fractions parameters of TGA1aGFP in epidermal cells

In epidermal cells the behavior of TGA1a-GFP fusion proteins is similar to the one in trichoma and guard cells - two mobility fractions are present in the nucleus, of which one is 2-3 times slower than the other and the ratio between them changes upon SA induction (15.6\%: $84.3 \%$ without SA and $42.1 \%: 57.9 \%$ with SA) again suggesting increasing participation of TGA1a-GFP proteins in interactions with other molecules after SA treatment.

\subsubsection{Characterization of the mobility properties of TetR-GFP in leaves}

The mobility studies of the control bacterial DNA-binding TetR-GFP fusion protein were performed with leaf surface tissues from the TetR-GFP tobacco transgenic lines \#7 and \#12, grown in soil in a climate chamber at $22^{\circ} \mathrm{C}$ and a light / darkness cycle of $16 / 8$ hours. Samples were prepared as described in 3.9.3 with and without SA induction. 


\subsubsection{Mobility of the TetR-GFP in nuclei of trichoma cells}

The LSM pictures before and after the FCS measurements with trichoma cells from TetR-GFP leaves are presented of Fig. 4.47:

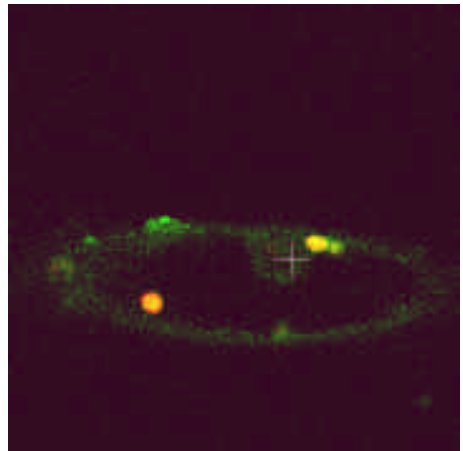

Trichoma cell-SA before FCS

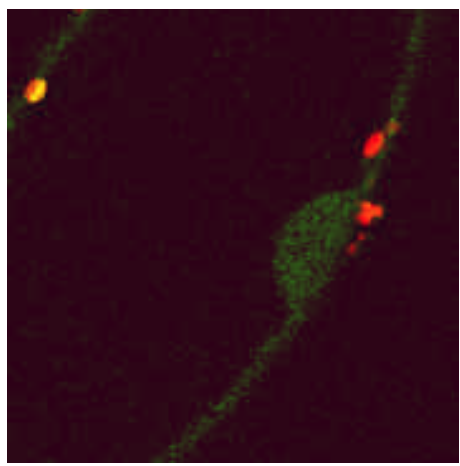

Trichoma cell + SA before FCS

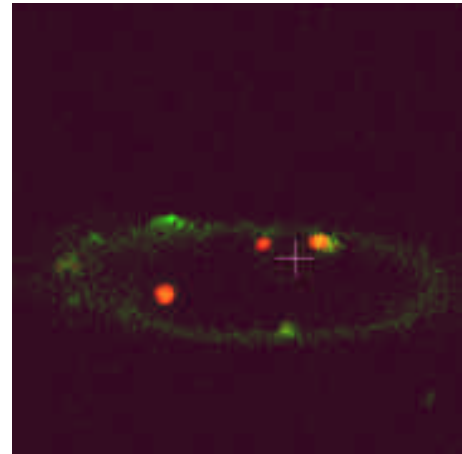

Trichoma cell -SA after FCS

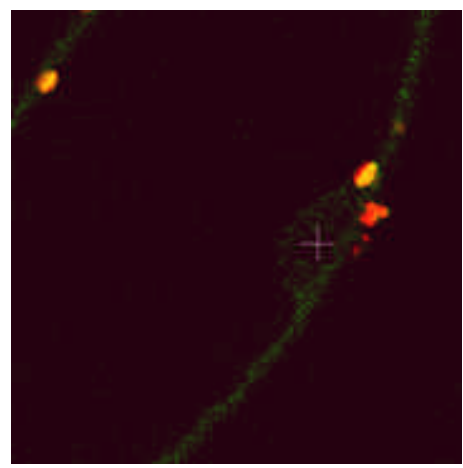

Trichoma cell + SA after FCS

Fig. 4.47. Trichoma cells from TetR-GFP \#12 without or with SA induction and before or after FCS

The overall GFP fluorescence in the nuclei of both non-induced and induced samples is decreasing after FCS as a result of the photobleaching of the GFP chromophores by the scanning laser, indicating that the control TetR-GFP fusion proteins are mobile in both cases, due to an absence of specific binding targets for TetR in plants.

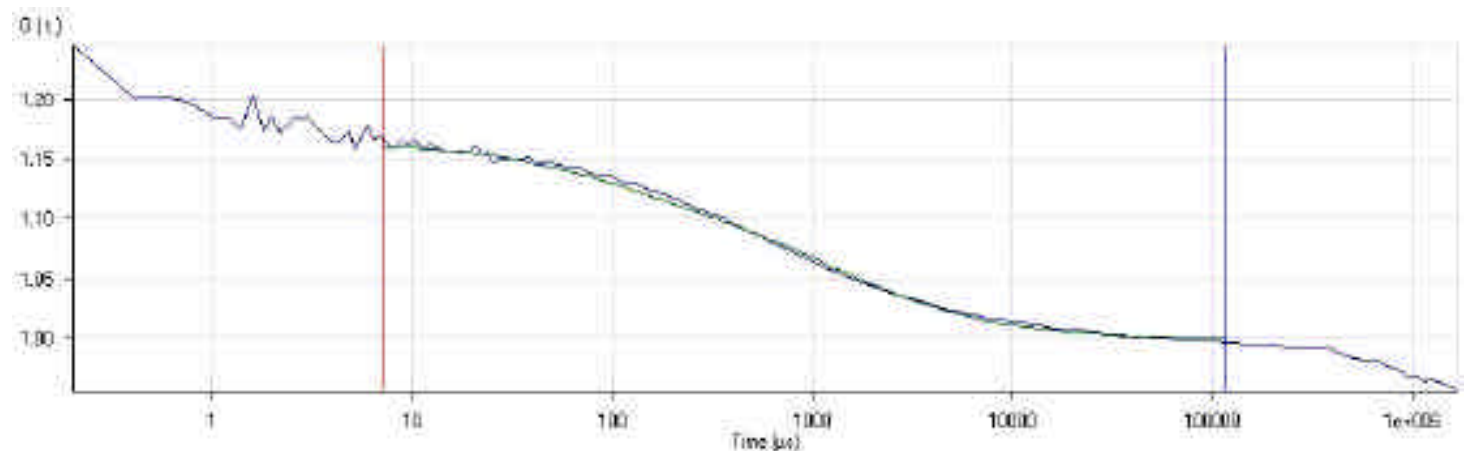

a) FCS autocorrelation curve of the non-S A-induced sample 


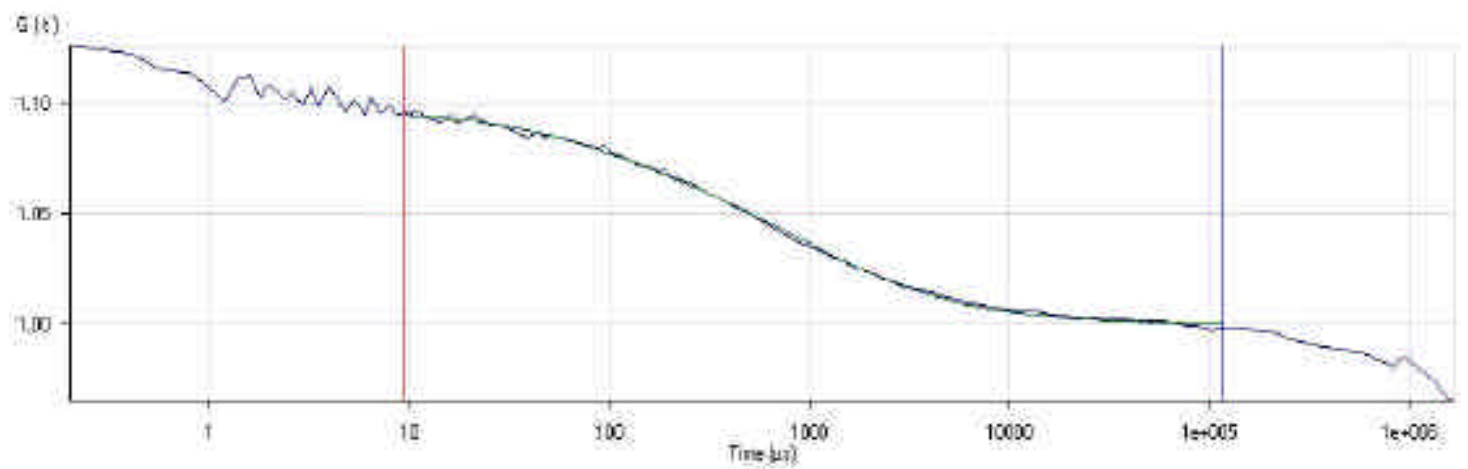

b) FCS autocorrelation c urve of the SA-induced sample

Fig. 4.48. Autocorrelation curves of TetR-GFP in trichoma cells

Both FCS curves on Fig. 4.48 without or with SA induction detect mobile fluorescent particles diffusing through the foci of FCS measurements, indicating no influence of SA on the mobility properties of TetR-GFP fusion proteins in trichoma cells.

\subsubsection{Mobility of TetR-GFP in stomata guard cells}

The LSM pictures of the FCS measurements with TetR-GFP in stomata guard cells are given in Fig. 4.49:

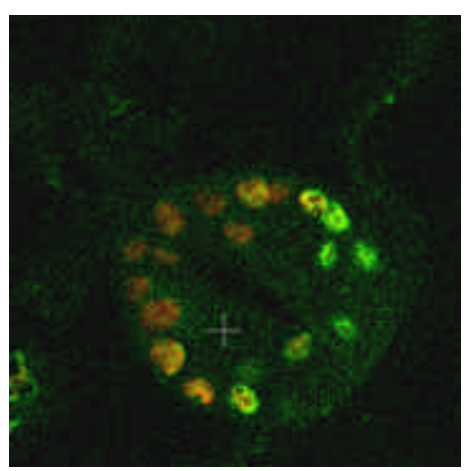

Guard cells-SA before FCS

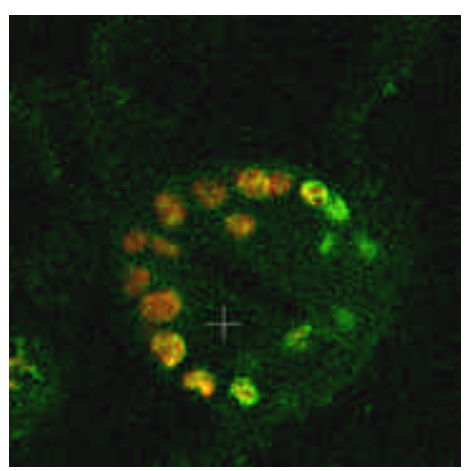

Guard cells-SA after FCS

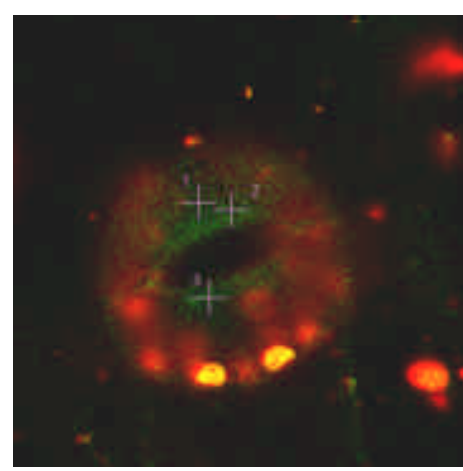

Guard cells + SA before FCS

Fig. 4.49. Stomata guard cells from TetR-GFP \#12 without or with SA induction and before or after FCS

The total GFP fluorescence in both non-induced and induced stomata guard cells is decreasing after FCS (similar to the observations in trichoma cells) due to photobleaching (FLIP) of the GFP chromophores; this shows again that the TetR-GFP fusion proteins are mobile and this conclusion can be confirmed also by the ACF curves (Fig. 4.50): 


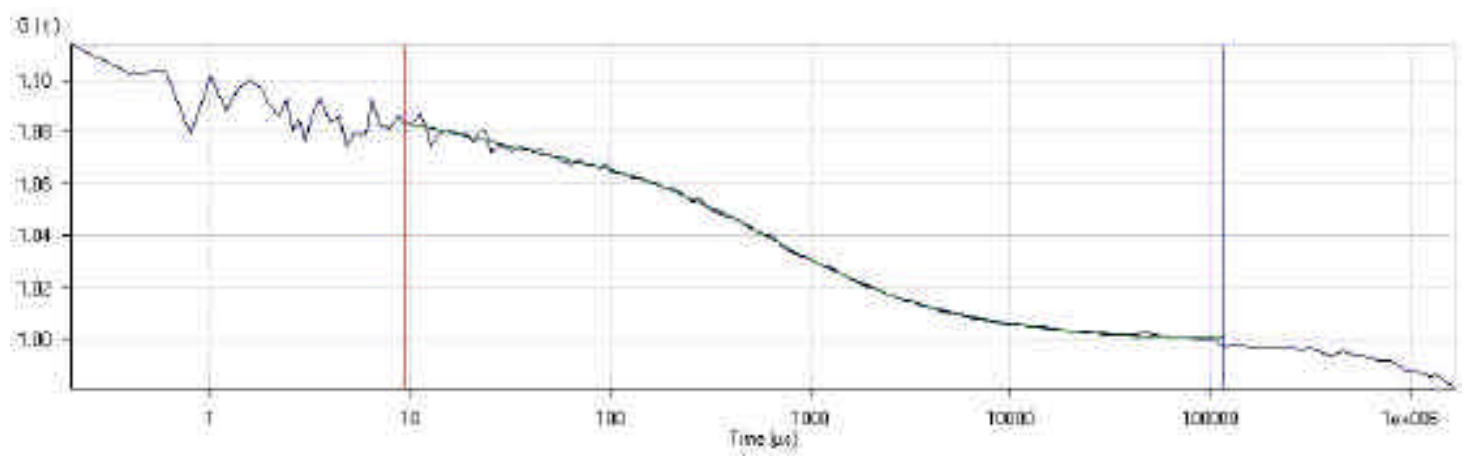

a) FCS autocorrelation curve of the non-SA-induced sample

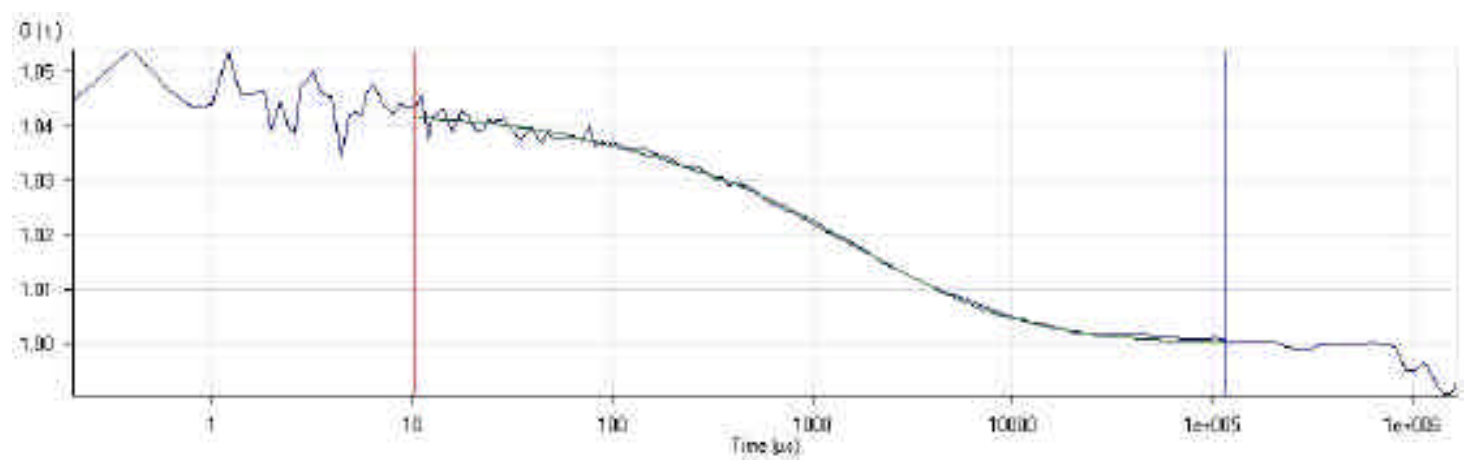

b) FCS autocorrelation curve of the SA-induced sample

Fig. 4.50. Autocorrelation curves of TetR-GFP in stomata guard cells

In stomata guard cells the FCS measurements (Fig. 4.50) again did not show any significant differences in the diffusion patterns of the TetR-GFP fusion proteins with or without SA induction judges by the quite similar shape of the two ACF curves, which is another indication (after the results with trichoma cells) that SA has no effect on the mobility of TetR-GFP

\subsubsection{Mobility of TetR-GFP fusion proteins in epidermal cells}

The LSM pictures of the FCS measurements with TetR-GFP in nuclei of epidermal cells are given in Fig. 4.51: 


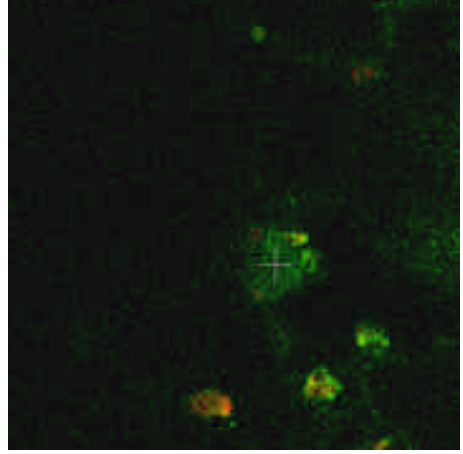

Epidermal cells -SA before FCS

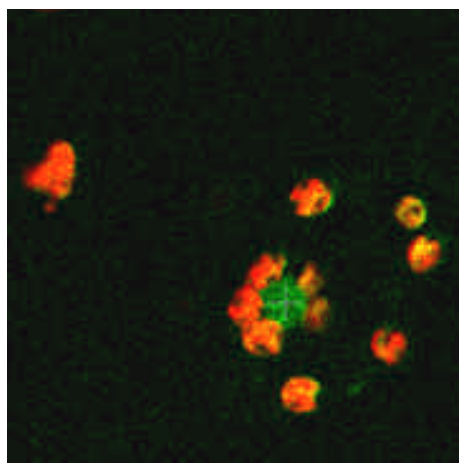

Epidermal cells + SA before FCS

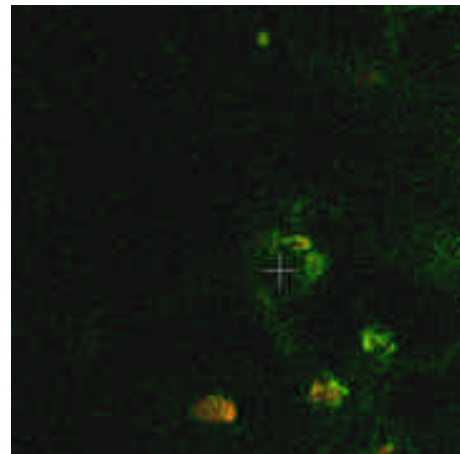

Epidermal cells -SA after FCS

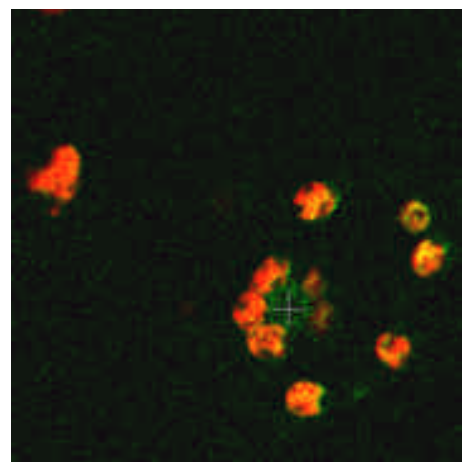

Epidermal cells + SA after FCS

Fig. 4.51. Epidermal cells expressing TetR-GFP without or with SA induction and before or after FCS

Once more the GFP fluorescence is diminishing after the FCS measurements, an indication that in non-induced epidermal cells TetR-GFP fusion proteins are also mostly mobile; the situation in the SA-induced cells is similar but more data is necessary in that situation because the FCS curve looks not so typical (Fig. $4.52 \mathrm{~b}$ ):

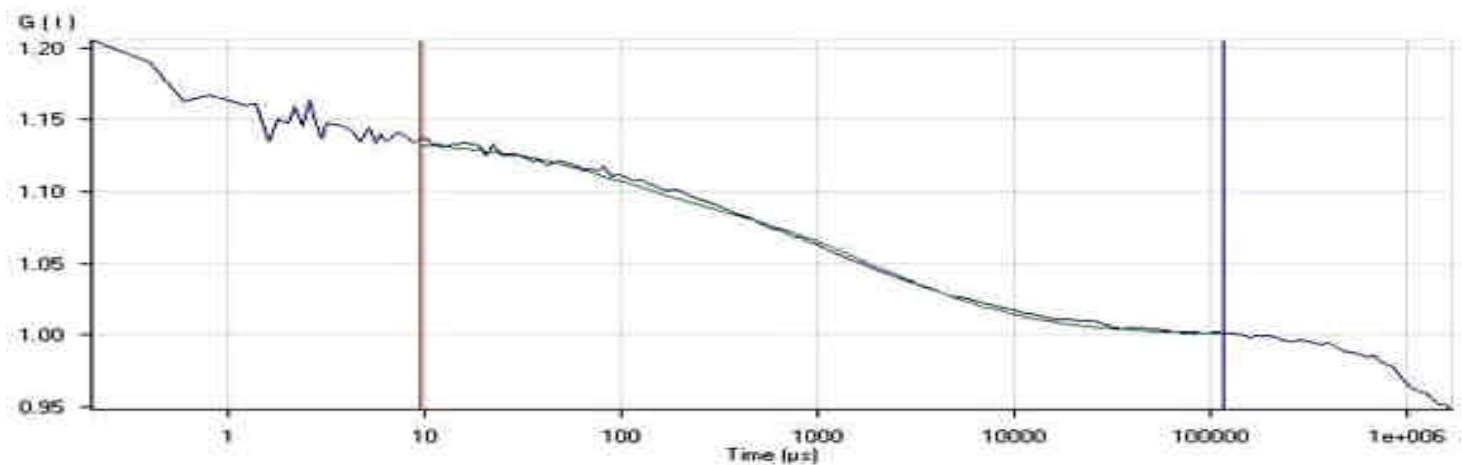

a) FCS autocorrelation curve derived from the non-SA-induced sample 


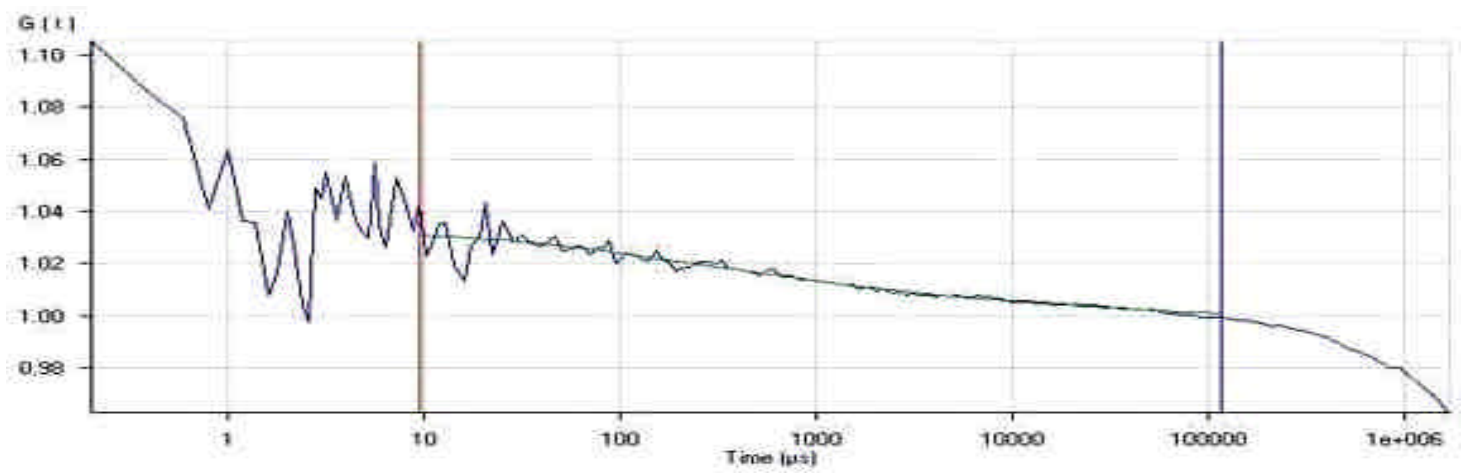

b) FCS autocorrelation curve derived from the SA-induced sample

Fig. 4.52. Autocorrelation curves of TetR-GFP in epidermal cells

The curve of the induced sample (Fig. 4.52 b) is not so typical for only-mobile fluorescent particles as the one from the non-induced sample (Fig. 4.52 a) but it also has an unusual drop in the beginning of the FCS curve, perhaps due to a low amount of fluorescent molecules in the detection volume; on the LSM pictures the TetR-GFP looks mobile but more measurements are necessary to determine more precisely the diffusion of TetR-GFP in epidermal cells.

\subsubsection{Summary of the mobility patterns of the TGA-GFP fusions}

\begin{tabular}{|l|c|c|c|}
\hline \multicolumn{1}{|c|}{-SA } & Trichoma cells & Stomata Guard cells & Epidermal cells \\
\hline \hline TGA2.1-GFP & mobile & mobile/immobile & immobile \\
\hline TGA2.2-GFP & mobile/immobile & mobile/immobile & mobile/immobile \\
\hline TGA1a-GFP & mobile & mobile & mobile/immobile \\
\hline TetR-GFP & mobile & mobile & mobile \\
\hline
\end{tabular}

\begin{tabular}{|l|c|c|c|}
\hline \multicolumn{1}{|c|}{ + SA } & Trichoma cells & Stomata Guard cells & Epidermal cells \\
\hline \hline TGA2.1-GFP & mobile/immobile & immobile & $?$ \\
\hline TGA2.2-GFP & mobile & mobile/immobile & immobile \\
\hline TGA1a-GFP & mobile/immobile & mobile/immobile & mobile/immobile \\
\hline TetR-GFP & mobile & mobile & $?$ \\
\hline
\end{tabular}

Table 4.2. Summary of the FCS/FLIP experiments

? stands for ambiguous results/insufficient data 


\section{Discussion}

\subsection{Subcellular localization of the GFP-tagged full-length TGA transcription factors}

Regulation of the subcellular localization of TGA transcription factors before and during the activation of the systemic acquired resistance (SAR) could be one of the ways the plants modulate the transcriptional activity of the as-1-like-containing promoters of immediate-early (Nt103, IEGT, etc.) and late $(P R)$ defense response genes. In order to study in living cells the presence of tobacco TGA2.1, TGA2.2 and TGA1a in the subcellular compartments (i.e. in the nucleus and in the cytosol), in-frame fusion proteins of the TGA factors (and of TetR, a bacterial DNA-binding protein as a control) and Cterminally-fused GFP reporter tags were constructed. Those constructs have been expressed transiently in plant protoplasts or constitutively in transgenic plants under the control of the HBT promoter (Sheen, 1993) and visualized by fluorescence or confocal laser-scanning microscopy. The non-fused GFP control and the non-targeted TetR-GFP fusion protein both showed more or less even distribution between the nucleus and the cytoplasm (see Fig. 4.2 and 46, Fig. 4.14 e), an indication that in plant cells the GFP protein tag itself contains no localization signals, which had been also demonstrated by Chui et al. (1996) and Haseloff et al. (1997). In contrast to that even distribution of the non-targeted GFP and TetR-GFP, all three TGA-GFP fusion proteins showed a prevailing tendency for accumulation in the nuclei of both transfected protoplasts and stabletransformed plants (see Fig. 4.3 to 4.5, Fig. 4.14), as it could be expected for eukaryotic transcription factors that have NLSs (RRLAQNREAARKSRLRKKAYVQQ) in the bZIP domains. The assumption that TGA-GFP proteins are accumulating in the nuclear compartment was clearly proven by 4,6-diamidino-6-phenylindole (DAPI)-staining of the chromatin in nuclei of transfected protoplasts, which have been already visualized for TGA-GFP fluorescence; when comparing the two images (see Fig. 4.7) it can be seen that both DAPI and GFP signals co-localize in the same cellular compartment i.e. in the nucleus. The expression of the reverse GFP-TGA constructs (the GFP-tag at the N terminus of TGA2.1 and TGA2.2) did not change the pattern of localization - the GFPTGA2.1 and GFP-TGA2.2 fusion proteins again were observed in the nuclei of transfected protoplasts and were excluded only from the nucleolus (Fig. 4.9); therefore it seems that the position of the GFP-tag either at the $\mathrm{N}$ or at C-terminus of the TGA factors has no effect on the NLS-determined nuclear targeting of the fusions. Furthermore, both part of the fusion proteins (the TGA N-terminal part and the GFP Cterminal part) seem to fold correctly in their native conformations, judging by the targeting to the nucleus and some other properties of the TGA derivatives (discussed later) and by the formation of functional chromophores of GFP, which depends on the native folding of the protein into the so-called " 3 -can" (Yang et al., 1996). The nuclear pattern of localization was not altered either by the transient co-expression of the TGA2.X-GFP fusion proteins and of wild-type heterodimer-partner TGA factors (TGA2.2 for TGA2.1-GFP and vice versa) driven by the sa me HBT promoter (see 4.1.4).

This nuclear localization of the GFP fusion proteins of TGA factors observed in living cells was expected and consistent with the biochemical data about the wild-type as-1- 
binding activity detected in nuclear protein extracts, known as "ASF-1" (Lam et al., 1989) which in tobacco consists mainly of TGA2.2 (about $80 \%$ ) and of TGA2.1 (about $10 \%$ ) as shown by Niggeweg et al. (2000b) by supershift analysis with an anti-TGA2.2serum, respectively anti-TGA2.1-serum. Still some experimental data from this work (asl-binding activity detected by EMSA in cytosolic extracts, see 4.3.3.2) and in the literature (detectable transcription of the mRNAs for A. thaliana TGA1 and TGA3, but those TGA factors were not detectable in the nuclear ASF-1 complex, Lam and Lam, 1995) suggests that there might be levels of regulation of the localization of some TGA factors, for example modulation of the nuclear entry of those proteins (by cytosolic retention by protein-protein interactions) or of a nuclear export of TGA factors, etc. In case that there might be some control of the subcellular distribution of the TGA factors, that might result in the formation of a depot of TGA molecules in the cytosol, retained there until the SA-signaling cascade is activated, then those retention interactions are released and TGA factors which are necessary for the activation of the gene expression of pathogen-induced genes are recruited into the nucleus; while other factors might be exported from the nucleus after fulfilling their functions. Another possibility is that there could be a shuttling of TGA factors between the nucleus and the cytosol with the purpose of co-importing other necessary inducible signals and factors which might lack a NLS of their own; such a mechanism in parsley cells was proposed by Ligternik et al. (1997) for the rapid (in $5 \mathrm{~min}$ ) nuclear translocation of the elicitor-responsive MAP kinase (EMP), involved in plant defense response, which lacks a NLS of its own. Such a pool perhaps is not detectable by the microscopical methods perhaps due to its very low concentration (the native abilities of the (hypothetical) cytosolic interacting partners to retain TGA proteins in the cytosol ae surely overwhelmed by the strong over-expression of the TGA-GFP fusions driven by the HBT promoter (Sheen, 1993), so most of the fusion proteins are directly imported into the nucleus) or due to some quenching of the GFP fluorescence by TGA-specific regulatory interactions (which might not allow the formation of fluorescent GFP chromophores until the interactions are released), or perhaps because of both and maybe other reasons.

In order to check whether there might be such a pool of TGA-GFP fusion proteins in the cytosol, nuclear and cytosolic protein extracts were prepared (see 3.7.3 for methods) and tested in Western blots with an affinity-purified polyclonal antiserum, recognizing equally well both the C-termini of TGA2.1 and TGA2.2 (Fig. 4.26 a), which was generated in the course of this work. Using this biochemical approach, minor fractions (compared to the nuclear pools) of the TGA2.1-GFP and TGA2.2-GFP fusion proteins were detected with the a-2.X-C antiserum in the cytosolic extracts from the corresponding transgenic plants (Fig. 4.28 a, a-2.X-C). In the nuclear preparation from the TGA2.1-GFP transgenic plant \#22 two bands of TGA2.1-GFP were present, probably the full-length TGA2.1-GFP and some kind of an N-terminally truncated form of TGA2.1-GFP, while only the truncated form of TGA2.1-GFP was detected in the corresponding cytosolic extract (an N-terminal cleavage of TGA2.1 was also reported by Kegler (2001) as an artifact from the preparation procedures). This result was confirmed with an antiserum against the N-terminus of TGA2.1 (Niggeweg, 1999) which recognize d much better the full-length TGA2.1-GFP, but was also able to detect the $\mathrm{N}$ truncated fusion protein both in nuclear and in cytosolic preparations, to a weaker extent 
in the later (Fig. $4.28 \mathrm{~b}, \mathrm{a}-2.1-\mathrm{N}$ ). TGA2.2-GFP was detected with the a-2.X-C antiserum both in nuclear and cytosolic extracts as a band of about $70 \mathrm{kDa}$ (the calculated molecular weight of TGA2.2 is about $36 \mathrm{kDa}$ and of GFP is about $27 \mathrm{kDa}$ ), which was much stronger in the nuclear preparation. The purity of the cytosolic extracts (i.e. whether they have been cross-contaminated with nuclear proteins) was controlled by parallel nuclear and cytosolic preparations from a TGA7 over-expressing plant (Schiermeyer, 2001); these extracts were tested with a antiserum against the N-terminus of TGA7 and there was a specific signal detectable only in nuclear fractions (Fig. $4.28 \mathrm{c}$, a-\&-N) which corresponds well with the results about an exclusively nuclear distribution of TGA7, as shown by Schiermeyer (2001). As an internal control for all nuclear and cytosolic extracts they had been tested with an antiserum against the TATA-binding protein (TBP); the specific signals were detected only in nuclear preparations (Fig. 4.28 d, a-TBP). Having in mind the results with the a-TGA7-N and a-TBP antisera, cytosolic preparations were assumed to be free from contamination with nuclear proteins and the detected TGA2.1-GFP and TGA2.2-GFP signals were considered coming from protein fractions, which are really present in the cytosol, possibly due to a cytoplasmic retention via protein-protein interactions, nuclear export, etc. Small pools of as-1-binding proteins (both endogenous and GFP fusions) were also detected in cytosolic fractions by EMSA (Fig. 4.27).

\subsection{Transient expression of separate $N$ - or $C$-termini of TGA factors}

One possible way of regulation of the subcellular distribution of the TGA factors leading to a minor portion of TGA factors in the cytosol might also be a nuclear export either as a single event (when some of them are no longer necessary in the nucleus) or as a shuttle mechanism for coimport for factors necessary for the SA-inducible gene expression. From an alignment analysis of the aminoacid sequences of the known TGA factors from $N$. tabacum and A. thaliana it came out that their extreme C-termini contain more or less conserved leucine-rich motifs (see Fig. 4.10) with a 2-2-1 spacing between the Leu residues, similar to already-known nuclear export sequences e.g. the NES in the activation domains of the HIV-1 Rev protein (Fischer et al., 1995) or of the HTLV-1 Rex protein (Bogerd et al., 1996). Those two NESs are classical examples for leucine-rich export signals which interact directly with a specific nuclear receptor called "e xportin-1" (XPO1/CRM1), a member of the transport receptors family of nuclear importins and exportins (known also as "karyopherins") in a Ran-GTP-dependent manner (Fornerod et al., 1997). The triple complex (protein-NES * Ran-GTP $*$ XPO1) is exported from the nucleus due to the ability of XPO1 to interact with nuclear pore components (Neville et al., 1997) and dissociates in the cytoplasm when the Ran-bound GTP is hydrolyzed to GDP by RanGAP/RanBP-activated Ran (Bischoff and Goerlich, 1997).

To find out whether there is XPO1-mediated nuclear export of tobacco TGA factors, fulllength proteins and also their separate $\mathrm{N}$ - or C-terminal domains were tested in a yeast two-hybrid system for interactions with the cDNA of $A$. thaliana exportin-1 (AtXPO1) in a collaboration with Dr. T Merkle (Freiburg University, Germany). In parallel transient assays were performed in tobacco BY-2 protoplasts with separate Nterminal or C- 
terminal domains of tobacco TGA factors, fused to the C-terminus of an in-frame fusion protein of $72.3 \mathrm{kDa}$ between chalcone synthase (CHS) and GFP; this reporter construct had been chosen because the domain fusions should be exceeding the molecular size for free diffusion of molecules through the nuclear pores $(50-60 \mathrm{kDa})$ in order to be targeted only due to their localization signals. The CHS-GFP fusion distributes evenly between the nucleus and the cytoplasm of BY-2 protoplasts, as shown with an out-of-frame fusion of CHS-GFP with the N-terminus of TGA1a, by which practically only CHS-GFP is expressed. TGA2.1 and TGA7 did not show interactions with AtXPO1 as full-length proteins in the Y2H system (see Table 4.1); clearly only TGA1a was able to interact with AtXPO1 both as a full-length protein (1-359 a.a.) and as a C-terminal domain (147-359 a.a.) but in the cytoplasm was localized only the Cterminal fusion protein (CHS-GFPTGA1a-C, Fig. $4.12 \mathrm{c}$ ), while the N-terminal fusion (Fig. 4.12 b) and the full-length TGA1a (not shown) were nuclear-localized, showing the prevalence of the tendency for nuclear localization of TGA1a. The results from the Y2H test about TGA2.2 could neither confirm nor exclude an interaction of XPO1 with the C-terminal domain of TGA2.2 (92-333 a.a.); in the transient assay the C-terminal domain of TGA2.2 fused to CHS-GFP localized in the cytoplasm, thus indicating export; therefore there seems to be some kind of interaction between TGA2.2-C and XPO1 but it was not clearly detectable, probably because this might not be a direct interaction but mediated by some other plant protein (and its yeast functional homologue) or because in planta TGA2.2 undergoes some kind of post-translational modification, which makes the interaction with XPO1 more efficient than in yeast cells. When two leucines in the putative NES at the G terminus of TGA2.2 were mutated by PCR into glycines (Leu315Gly and Leu318Gly) and this CHS-GFP-TGA2.2-C-LeuMut construct was transiently expressed in BY-2 protoplasts no change in the localization was observed, compared to the wild-type CHSGFP-TGA2.2-C fusion; therefore the leucine-rich aminoacid stretch at the C-termini of the TGA factors seems not to be a functional NES of the XPO1-recognizable type and further studies will be necessary to map the aminoacid residues determining the interaction between AtXPO1 and TGA1a, and to clarify the export properties of the Cterminus of TGA2.2. The possibility that the Cterminal constructs of the TGA factors stay in the cytoplasm because they have no NLS and are not imported in the nucleus at all could not be eliminated with certainty, but it seems not so likely since the basic CHSGFP protein $(72.3 \mathrm{kDa})$ is entering the nucleus despite the fact that it exceeds the empirically-determined limit for free diffusion through the nuclear pores; furthermore the two C-terminal fusions tested (of TGA2.2 and TGA1a) have slight differences in the pattern of localization - CHS-GFP-TGA2.2-C is completely excluded from the nucleus, while a portion of the CHS-GFP-TGA1a-C proteins is observed also in the nucleoplasm; still further experiments e.g. by treatment of the protoplasts with Leptomycin B (LMB, a specific inhibitor of XPO1/CRM1) are to be carried out to investigate this option.

\subsection{DNA-binding properties of the TGA-GFP fusion proteins}

The as-1-binding activities, known as "ASF-1" in nuclear preparations (Lam et al., 1989) and as "SARP" in total protein extracts (Jupin and Chua, 1996) have been shown to be quite similar in composition, comprising of more than $80 \%$ of TGA2.2 and about $10 \%$ 
of TGA2.1 in tobacco leaves, as detected in supershift analysis and Western blots (Niggeweg et al., 2000b). This information about TGA2.2 correlates well with previously reported data from Southwestern blots (Jupin and Chua, 1996), where a protein of about $40 \mathrm{kDa}$ (TGA2.2 has a calculated molecular weight of about $36 \mathrm{kDa}$ ), shorter than TGA1a (which is about $43 \mathrm{kDa}$ ) but immunologically related to it, was pointed out as the major component of SARP. A Western blot of purified SARP, tested with an antiserum against TGA2.1 detected a shorter TGA2.1 protein, compared to the recombinant one (Niggeweg et al., 2000b), probably due to an artificial N-terminal truncation during the protein extraction procedure, as shown by Kegler (2001). So far TGA1a was not detected by supershift analysis in either ASF-1 or SARP complexes neither by Niggeweg et al. (2000b), nor by Lam and Lam (1995), but it was detectable by immuno-precipitation in purified SARP from BY-2 suspension cell culture (Johnson et al., 2001). As long as the major part of ASF-1/SARP was shifted with the a-TGA2.2-antiserum, it seems likely that most of the TGA dimers that form ASF-1/SARP are either homodimers of TGA2.2 and/or heterodimers of TGA2.2 with already-known TGA factors (TGA2.1, TGA1a) or perhaps not-yet-identified members of the TGA family.

In this work, a GFP-tag of $27 \mathrm{kDa}$ was fused in-frame at the Gtermini of TGA2.1, TGA2.2 and TGA1a and the resulting TGA-GFP constructs were expressed constitutively in transgenic tobacco plants (see 4.2). In order to find out whether those fusions are still able to bind to the as-1-element, crude protein extracts were prepared from leaves of non-induced sterile-cultured plants with similar level of mRNA of the different TGA-GFP fusions and tested in a gel retardation assay for as-1-binding activity (4.2.1). The green fluorescent protein adds additional $27 \mathrm{kDa}$ to TGA2.1 $(50 \mathrm{kDa})$, TGA2.2 $(36 \mathrm{kDa})$ and TGA1a $(43 \mathrm{kDa})$, therefore as-1-binding complexes containing any kind of dimers of the TGA-GFP fusion proteins with themselves or with endogenous TGA factors should run slower (higher) in native gel electrophoresis than the ones built only from endogenous TGA factors; additionally it should be taken into consideration that the as-1-element can be occupied by one TGA dimer (the lower band in EMSAs, Fig. 1.3) or by two TGA dimers (the upper band in EMSAs, Fig. 1.3) as suggested by Tokuhisa et al. (1990). The results from the EMSA performed with crude protein extracts from wild-type (SNN) and TGA-GFP transgenic plants (see Fig. 4.16 and the legend to it) clearly demonstrate that the TGA-GFP fusions maintain their ability to form dimers and to bind to the as-1-element - the TGA2.2-GFP fusion protein dimerized both with itself and with endogenous TGA2.2 factors, resulting in both a single and a double occupation of the as-1-element with "TGA2.2 homodimers" in several combinations; the TGA2.1-GFP fusion was able to form heterodimers with the endogenous TGA2.2 factors, which also led to a single and a double occupation of as- 1 by homodimers of the endogenous TGA2.2 and the heterodimers of TGA2.1-GFP with TGA2.2 in different combinations, while TGA1a-GFP was also forming heterodimers with the endogenous TGA2.2, but that resulted only in a single occupation of as-1 (besides the wild-type binding activity, see SNN) by the TGA1a-GFP/TGA2.2 heterodimer. The se observations for a single an a double occupation of as-1-element by the homodimers of TGA2.2 and the heterodimers between TGA2.1 and TGA2.2, and the preference of TGA1a for a single occupation of as-1 correlate well with what was detected in EMSAs by Niggeweg et al. (2000a). It has to be mentioned that the as-1-binding activity described above was 
detected by an in vitro assay in protein extracts from non-induced plants grown in sterile conditions, which might not reflect $100 \%$ exactly the real situation; still it seems that all three TGA-GFP fusion proteins bind to the as-1-element under non-inducing conditions, which might represent a basal level of binding activity or it is also possible that the GFPtag at the C-terminus of the TGA factors influences positively the DNA-binding properties of TGA-GFP fusion factors, eventually by disturbing the binding of negative regulators (e.g. SAI, Jupin and Chua, 1996) to SARP.

\subsection{Effects of the expression of TGA-GFP fusions on the as-1-mediated gene expression}

The importance of TGA factors for the regulation of the expression of both immediateearly and late SA-inducible plant defense genes has been shown by the expression of dominant negative mutants of TGA2.2 in tobacco (TGA2.2trd, Niggeweg et al., 2000b) and of TGA2 in Arabidopsis (T2m, Pontier et al., 2001) which were not able anymore to bind to the $a s-1$-element but still were able to form dimers with other TGA factors. Those two mutants affected in the same way (negatively) the expression of the immediate-early GST genes but differed in the effect on the expression of late genes (TGA2.2trd reduced PR-1a gene expression, while T2m enhanced the expression of PR1, PR2 and PR3). Those results suggest that the promoters of GSTs and $P R$ s might differ in the recruitment of different TGA factors that might have positive or negative effects on the modulation of the transcriptional activity of $a s$-1-like -containing promoters.

In this work the influence of the TGA-GFP fusion proteins on the SA- or 2,4-D-inducible expression of the immediate-early GST gene Nt103 was studied. As discussed in 5.3, all three TGA2.1-GFP, TGA2.2-GFP and TGA1a-GFP fusions in crude leaf protein extracts from sterile-cultured plants were found to bind in vitro to the as-1-element without pretreatment of the leaves with SA or 2,4-D; however that did not lead to a constitutive activation of the expression of Nt103 (see the 0 time points on Fig. 4.17 and Fig. 4.22) indicating that the activation or/and the deactivation of additional components is necessary for the as-1-mediated transcription to take place. An increase of Nt103 mRNA was observed after 24 hours of floating of non-induced leaf discs (Fig. 4.17 -SA) probably due to a SA-independent late mechanism of transcription activation, but at the early time points without SA only very weak levels of the Nt103 transcript was detectable. In contrast, the effect of SA on the Nt103 mRNA level was visible as a 2-4fold average increase in leaves of both TGA2.1-GFP \#22 and TGA2.2-GFP \#16 plants and as a decrease or no effect in leaves of TGA1a-GFP \#19 plant (Fig. 4.17; Fig. 4.19 and Fig. 4.22), suggesting that the as-1-containing promoter of Nt103 can be induced by SA stronger in the presence of TGA2.1-GFP and TGA2.2-GFP fusion proteins than in the wild-type situation, probably because those two fusion proteins are involved in the formation of more active transcriptional complexes. The results about TGA1a-GFP suggest a negative effect of TGA1a-GFP fusion protein in leaves during the SA induction of $N t 103$, possibly a result of the formation and binding of non-functional (at least in leaves) heterodimers of TGA1a-GFP and the endogenous TGA factors to the Nt103 promoter. Upon 2,4-D treatment of leaf discs (Fig. 4.19 and 4.22) the effects of the TGAGFP fusions on the GST expression were less pronounced (also observed about TGA2.2 
by Niggeweg et al., 2000b); still there was a positive impact of the GFP fusions of TGA2.1 and TGA2.2, and a slightly negative effect of TGA1a-GFP on the Nt103 mRNA level, probably due to the same reasons discussed for the SA induction. In conclusion, the expression of the TGA2.X-GFP fusion proteins under the strong HBT promoter leads to similar effects (2-4 fold increase of the transcription of Nt103) as from an overexpression of functional TGA2.X factors (Kegler, 2001; Niggeweg, 1999); therefore the GFP tag seems not to disturb their activation properties and their regulatory interactions (or another possibility is that it might hinders only the negative of these interactions). As for TGA1a-GFP, the results of the experiments in this work seem in some contradiction with the activation properties of TGA1a, observed by Pascuzzi et al. (1998), Johnson et al., (2001) and others, so it might be either that the root-specific TGA1a can not mediate or hinders the SA or 2,4-D signaling in leaves, or the GFP tag at its C-terminus possibly influences negatively its activation potential.

\subsection{Analysis of the mobility properties of the TGA-GFP fusion proteins in nuclei}

It is logical to suppose that a spatial organization of the nuclear protein complexes and the chromatin might be important for the proper regulation of the nuclear processes and indeed in the nucleoplasm of interphase nuclei there seems to be a number of subcompartments of protein complexes (often referred to as "factories", Cardoso et al., 1999) implicated in essential processes such as replication, transcription, splicing, etc. (Lamond and Earnshaw, 1998; Misteli and Spector, 1998; for review see Cook, 1999). The mechanisms through which these compartments form and by which protein are transported through the nucleoplasm and recruited in those complexes are still largely unknown and subject of discussion; only recently the ectopic usage of GFP as a fluorescent marker has made it possible to observe directly the protein dynamics in nuclei of living cells, thus shedding more light in the organization of nuclear processes like DNA repair (Houtsmuller et al., 1999); regulation of gene transcription (McNally et al., 2000; Chen et al., 2002); RNA processing (Phair and Misteli, 2000), etc.

In the present work the nuclear molecular dynamics of the GFP-tagged TGA2.1, TGA2.2 and TGA1a tobacco transcription factors (and the bacterial DNA-binding TetR-GFP as a control) under non-induced and induced (+SA) conditions have been studied by fluorescence correlation spectroscopy (FCS, Madge et al., 1972) which has been combined with confocal laser-scanning microscopy (CLSM) performed before and after FCS measurements. This combination of methods gave the possibility of dual detection of the mobility patterns of the fusion proteins by estimating qualitatively the fluorescence loss in photobleaching (FLIP) at the focus of FCS measurements from the CLSM photos, which was taken together with the more precise quantitative measurement of the diffusion rates of the fluorescent molecules passing through the detection volume by FCS. The raw experimental data from the FCS measurement was fitted by the ConfoCor2 software using Levenberg-Marquardt least squares fitting to equations for two- or onecomponent diffusion model functions and the diffusion parameters of the fluorescent particles were derived from those model equations fits. Different types of cells (trichoma, stomata guard and epidermal cells) from tissues peeled off from the lower leaf surface of 
the transgenic plants were used for measurements, giving the chance for detection of celltype-specific patterns of mobility of the different TGA-GFP fusions. In particular, TGA2.1-GFP (see chapter 4.4.1) was present in nuclei of non-induced trichoma cells as two types of mobile fractions (slow- and fast-diffusing) in a ratio of 1:4 (slow: fast) as detected by FCS; this mobility was also recognizable on the CLMS photos as a general loss of fluorescence (FLIP) in the whole nucleus. Treatment with SA lead to a change in the ratio to 2:3 (slow: fast) e.g. to a 2-fold increase of the slow-diffusing fraction (which because of its decreased mobility is presumably involved in interactions with DNA e.g. with the as-1-element, or with other proteins), suggesting that upon induction the binding of TGA2.1-GFP heterodimers to the as-1-element is enhanced. In the nuclei of stomata guard cells the two mobile fractions were present at a 1:2 (slow: fast) ratio without stimulation; after SA treatment the fluorescent particles became immobile (detectable also on the CLSM pictures as a localized FLIP at the focus of measurements), indicating an almost complete association of TGA2.1-GFP in larger immobile structures (possibly including also DNA and other proteins). The situation in epidermal cells still needs further investigation, since not enough cells were measured to allow an explanation of the observed variations in the mobility pattern of TGA2.1-GFP in the nuclei of this type of cells. In contrast to TGA2.1, TGA2.2-GFP (chapter 4.4.2) in trichoma cells tends to become more mobile after SA treatment judged by the decrease of the slow-diffusing fraction, probably as a result of the SA-stimulated dissociation of the DNA-binding protein complexes in which TGA2.2-GFP is involved, or due to the high rates of their association and dissociation. In nuclei of stomata guard cells the application of SA does not seem to have effect on the diffusion parameters of TGA2.2-GFP - the ratio between the slow-diffusing and the fast-diffusing fractions stays approximately 1:1 without or with SA, possibly due to a saturation of the as-1-binding sites and the TGA2.2-GFPcontaining protein complexes. As for epidermal cells, the majority of TGA2.2-GFP fluorescent molecules seem to be immobile in both non-induced and induced samples (seen also as localized FLIPs on the CLSM photos), suggesting again a saturation of the TGA2.2-GFP targets and interactions. The effect of SA on the mobility of TGA1a-GFP (chapter 4.4.3) was similar in all cell types tested - the ratio between the slow-diffusing and the fast-diffusing component changed from 1:4 (in non-induced cells) to 2:3 in induced cells, indicating that SA enhances the immobilization also of the TGA1a-GFP fluorescent molecules (presumably by the formation of DNA-binding complexes), but due to the preference of TGA1a for a single occupation of the as-1-element, only a fraction of the activated TGA1a heterodimers can find a free DNA target, and the rest stayed mobile (although probably induced). The diffusion parameters of the bacterial TetR-GFP fusion, used as a control DNA-binding protein (chapter 4.4.4) did not change after SA treatment in all tested cell types, confirming in this way the specific effect of SA on the mobility of the TGA transcription factors (presumably a result of the DNAbinding affinity and/or their involvement in protein complexes). The interpretation of the diffusion patterns described above is somehow difficult, since in some cases the mobility behavior of one and the same fusion protein differs in the different tested cell types and sometimes varies also in cells of the same type (as in the case of TGA2.1-GFP in epidermal cells) perhaps due to differences in the developmental and cell-cycle phases of the cells; still for TGA2.1-GFP and TGA1a-GFP the experimental data suggests that SA enhances in general their binding affinity for the as-1-element, while for TGA2.2-GFP it 
seems that there might be a cell-specific type of regulation of its DNA-binding activity; more detailed SA induction time-course studies still have to be performed in the future to investigate those observations.

As mentioned above, the FCS data was fitted to model equations for 2- or 1-component free diffusion; still another interpretation of the experimental FCS data can be by using a model function for a 1-component anomalous sub-diffusion (Schwille et al., 1999; Wachsmuth et al., 2000) where the time dependence can serve as a measure for the degree of obstructions, caused by immobile obstacles, by a broad range of binding affinities, by caging or trapping, etc. This type of long-tail kinetics (Nagle, 1992) was observed using a fusion between EGFP and B-galactosidase as a reporter particularly in the nucle $i$ of transfected AT- 1 and COS-7 cells. The mobility of the fusion protein also varied when measured in cells from the same sample, probably due to differences in the condensation of chromatin during the different phases of the cell cycle (Wachsmuth et $a l ., 2000)$. Still both types of approaches reveal changes in the diffusion parameters of the TGA-GFP proteins upon stimulation with SA, which are presumably due to modulations of their interactions with components and complexes in the nucleoplasm Those type of differences in the mobility characteristics of DNA-binding proteins involved in transcriptional events have already been demonstrated by the "fluorescence recovery after photobleaching" (FRAP) technique for GFP fusions of the human TATA-binding protein and of the general transcription factor TFIIB by Chen et al. (2002). In transcriptionally active interphase nuclei the rate of the fluorescence recovery after photobleaching of the GFP-TBP molecules was much slower (in about $20 \mathrm{~min}$ ) in comparison to that of GFPTFIIB, whose fluorescence recovered within a few seconds; these findings suggest that TBP remains bound to the interphase euchromatin for multiple rounds of transcription and bleaches at the laser illumination focus with much slower rate of replacement of the bleached with non-bleached molecules, while TFIIB seems to cycle on and off the promoters of the transcribed genes, therefore bleached molecules are replaced quite fast by fluorescent ones. Similar bleaching effects and fluorescence recovery were observed in the present work, and although the diffusion parameters of the fluorescently-tagged TGA factors were determined by FCS and not by the rate of recovery of the fluorescence, it looks very probable that both the study of Chen et al. (2002) using the FRAP technique, and the present study using CLSM before and after FCS have investigated the same type of phenomenon - the variations in the mobility of GFP-tagged DNA-binding proteins before and during their implication in transcriptional events in the nucleus.

\subsection{Outlook}

Fluorescence correlations spectroscopy (FCS) is a very sensitive and reliable method for determining concentration, diffusion rates and other parameters of fluorescent molecules, still the conclusions from it have the drawback that in this case they are based on the assumption that changes in the mobility of the TGA-GFP fusion proteins are corresponding with the level of their DNA binding or with the interactions with other protein complexes, which, although logical might happen not to be entirely correct; therefore alternative methods for detection of DNA-protein or protein-protein interactions 
should also be performed, and by comparison with the FCS data the regularities between mobility and interactions should be established.

Chromatin immunoprecipitation (ChIP, Orlando, 2000) is a relatively new technique which detects DNA-protein complexes, stabilized via cross-linking with formaldehyde that are immuno-precipitated and the DNA fragments, derived from promoter areas after sheering of the genomic DNA subsequently serve as templates for PCR amplification after their release from the proteins. The advantage of this technique compared to gelshift assays is that the DNA-protein interactions happen in the plant rather than in vitro (as is with the binding reaction for gelshifts); therefore ChIP should reflect better the situation in vivo and more precise investigations of stimuli-dependent differences in the DNAbinding activity of proteins (e.g. of the TGA factors) can be performed with it.

Experiments with protein-protein interaction assays e.g. BIAcore chips with immobilized TGA proteins, on which via the "surface plasmon resonance" (SPR) technology the characteristics of the interacting partners and the kinetics and the order of the binding events can be detected, or "pull-down" assays of protein complexes with specific antisera aimed to detect differential interactions of the TGA factors might also be helpful to understand their relations with other proteins before and after stimulation.

Searching for interaction partners of the TGA factors involved in the control of their subcellular localization (one of which might be exportin-1) can also be performed in the classical yeast "two-hybrid" (Y2H) system, however there might be a limitation that potential cytosolic interactions might not be effectively detectable either because the reporter interaction happens in the nucleus of the yeast cell (that obstacle can be surmounted by using the "Ubiquitin-split" modification of $\mathrm{Y} 2 \mathrm{H}$ ) or because the TGA factors or their interacting partners might undergo post-translational modifications in planta before or after the SA-signaling cascade is activated.

Another possibility is to express in plant cells the studied proteins as fusions with separate domains of murine dihydrofolate reductase (DHFR, Subramaniam et al., 2001) which only after an interaction between the proteins reconstitutes the active enzyme, able to bind fluorescein-conjugated methotrexate (a high-affinity inhibitor of DHFR) in a 1:1 ratio; the resulting complex can be visualized by spectroscopy, fluorescence microscopy, fluorescence-activated cell sorting, etc.

It still has to be investigated in more details what is the effect of the GFP tag at the Cterminus of the TGA fusion proteins and whether it disturbs some interactions with potential negative regulators of the DNA-binding activity of the TGA factors, which are binding to this domain e.g. the TGA1a factor and the $\mathrm{pl} 20$ repressor (Johnson et al., 2001). 


\section{Summary}

Salicylic acid (SA) is an important signaling molecule in the regulation of plant defense response against pathogens. as-1-like cis-elements present in the promoters of many defense genes mediate SA- and also auxin-inducible gene expression. Those elements are recognized by the ASF-1/SARP protein complex, main components of which are DNAbinding proteins from the TGA family of bZIP plant transcription factors.

In this work the subcellular distribution of the TGA factors as a possible way for control of the transcriptional activity of the as-1-containing promoters was studied. In-frame fusion proteins of TGA2.1, TGA2.2 and TGA1a with GFP were created, over-expressed under the control of the HBT promoter transiently in plant protoplasts or stably in transgenic plants and visualized directly in the living cells by fluorescence and confocal laser-scanning microscopy. Most of the fluorescence from the three TGA-GFP fusion proteins was observed predominantly in the nucleus (excluding the nucleolus) in the microscopical studies, still with biochemical methods a pool of TGA2.1-GFP and TGA2.2-GFP was detected with antiserum recognizing both their C-termini in cytosolic extracts from the corresponding transgenic plants, perhaps due to a cytoplasmic retention or to nuclear export of TGA factors. C-terminal partial fusions of TGA2.2 and TGA1a at the C-terminus of CHS-GFP were also observed in the cytosol in transient assays, probably due to an export activity, but this still has to be further investigated.

In a gel-retardation in vitro assay the TGA-GFP fusion proteins were still able to recognize the as-1-element and to bind to it in the form of homo- or hetero-dimers. TGA2.2-GFP formed dimers with itself and also with endogenous TGA2 factors, while TGA2.1-GFP and TGA1a-GFP formed heterodimers with endogenous TGA2.2 A single and a double occupation of the as- 1 -element with different combinations of homo- and hetero-dimers were observed in EMSA with crude protein extracts from TGA2.1-GFP and TGA2.2-GFP transgenic plants and only a single occupation of the as-1-motif by a TGA1a-GFP/TGA2.2 heterodimer was detected with an extract from a TGA1a-GFPexpressing plant.

The TGA-GFP fusion proteins were also able to influence the expression level of the immediate-early GST gene Nt103 upon induction with salicylic acid or auxin in leaves. TGA2.1-GFP and TGA2.2-GFP showed in general a positive effect on the Nt103 mRNA level (2-4-fold increase compared to wild-type) which was stronger in the SA-induced expression than in the 2,4-D samples, while TGA1a-GFP seemed to influence slightly negatively or not at all the expression of Nt103 in both cases in leaves.

The mobility parameters of the different TGA-GFP fusion proteins in the nucleus were studied by FCS, combined with CLMS. In general salicylic acid had an enhancing effect on the interactions of the TGA2.1-GFP fusions in trichoma and stomata guard cells tested, as concluded from the increase of the slow-diffusing or of the immobile fraction after SA stimulation, which is presumably due to their involvement in interactions with other nuclear components (DNA or proteins). SA treatment made the TGA2.2-GFP fluorescent fusion proteins more mobile in nuclei of trichoma cells and had little or no effect on their mobility in stomata guard and epidermal cells. The slow fraction of the TGA1a-GFP fusion proteins increased after stimulation with SA in trichoma, stomata guard and epidermal cells. SA had no effect on the mobility of TetR-GFP. 


\section{Literature cited:}

Altschul SF, Madden TL, Schaeffer AA, Zhang J, Zhang Z, Miller W and Lipman DJ (1997)

Gapped BLAST and PSI-BLAST: a new generation of protein database search programs.

Nucl Acids Res 25, 3889-3402

Amsterdam A, Lin S, Moss L and Hopkins N (1996)

Requirements for green fluorescent protein detection in transgenic zebrafish embryos.

Gene 173, 107-111

\section{An G, Gosta M and Ha SB (1990)}

Nopaline synthase promotor is wound inducible and auxin inducible.

Plant Cell 2, 225-233

\section{Ausubel FM, Brent R, Kingston RE, Moore DD, Seidman JG and Struhl K (1988) \\ Current protocols in molecular biology.}

John Wiley \& Sons, New York 10022, USA

Baulcombe DC, Chapman S and Santa Cruz S (19950

Jellyfish green fluorescent protein as a reporter for virus infections.

Plant J 7 (6), 1045-1053

Benfey PN, Ren L and Chua NH (1989)

The CaMV $35 \mathrm{~S}$ enhancer contains at least two domains which can confer different developmental and tissue-specific expression patterns.

EMBO J 8, $2195-2202$

\section{Bent A (1996)}

Function meets structure in the study of plant disease resistance genes.

Plant Cell 8, 1757-1771

\section{Bevan M (1984)}

Binary Agrobacterium vectors for plant transformation.

Nucl Acids Res 12 (22), $8711-8721$

\section{Bischoff FR and Goerlich D (1997)}

RanBP1 is crucial for the release of RanGTP from importin- $\beta$-related nuclear transport factors.

EMBO J 14, $705-715$

Blumwald E, Aharon GS and Lam BC-H (1998)

Early signal transduction pathways in plant-pathogen interactions.

Trends Plant Sci 3, 342-346

Bogerd HP, Fridell RA, Bensom RE, Hua J and Cullen BR (1996)

Protein sequence requirements for function of the human T-cell leukemia virus type 1 Rex nuclear export signal delianted by a novle in vivo randomization-selection assay.

Mol Cel Biol 16 (8), 4207-4214

Bolwell GP, Butt VS, Davies DR and Zimmerlin A (1995)

The origin of the oxidative burst in plants.

Free Rad Res Comm 23, 517-532 
Boot KJM, van der Zaal BJ, Velterop J, Quint A, Mennes AM, Hooykaas PJJ and Libbenga KR (1993)

Further characterization of expression of auxin-induced genes in tobacco (Nicotiana tabacum) cellsuspension cultures

Plant Physiol 102, 513-520

\section{Bouchez D, Tokuhisa JG, Llewellyn DJ, Dennis ES and Ellis JG (1989)}

The ocs-element is a component of the promotor of several T-DNA and plant viral genes.

EMBO J 8 (13), 4197-4204

\section{Bradford MM (1976)}

A rapid and sensitive method for the quantification of microgram quantities of protein utilizing the principle of protein dye binding.

Anal Biochem 72, 248-254

Bradley DJ, Kjellbom P and Lamb CJ (1992)

Elicitor- and wound-induced oxidative cross-linking of a proline-rich plant cell wall protein: a novel rapid defense response.

Cell 70, 21-30

Brent R and Ptashne M (1981)

Mechanisms of action of the lexA gene product

Proc Natl Acad Sci USA 78, 42044208

Brunet A, Kanai F, Stehn J, Xu J, Sarbassova D, Frangioni JV, Dalal SN, DeCaprio JA, Greenberg MF and Yaffe MB (2002)

14-3-3 transits to the nucleus an participates in dynamic nucleocytoplasmic transport.

J Cell Biol 156 (5), 817-828

Bullock WO, Fernandez JMand Short JM(1987)

XL1-Blue: A high efficiency plasmid transforming recA-Escherichia coli strain with ßgalactosidase selection.

Biotechniques 5, 376-379

Cao H, Bowling SA, Gordon AS and Dong X (1994)

Characterization of an Arabidopsis mutant that is nonresponsive to inducers of systemic acquired resistance Plant Cell 6, 1583-1592

Cao H, Glazebrook J, Clarke JD, Volko S and Dong X (1997)

The Arabidopsis NPR1 gene that controls systemic acquired resistance encodes a novel protein containing ankyrin repeats.

Cell 88, 57-63

Cardoso MC, Sporbert A and Leonhardt H (1999)

Structure and function in the nucleus: subnuclear trafficking of DNA replication factors.

J Cell Biochem Suppl 23/33, 15-23

Casper S and Holt C (1996)

Expression of the green fluorescent protein-encoding gene from a tobacco mosaic virus-based vector.

Gene 173, 69-73

Chalfie M, Tu Y, Euskirchen G, Ward W and Prasher D (1994)

Green fluorescent proteins as a marker for gene expression.

Science 263, 802-805 
Chen D, Hinkley CS, Henry RW and Huang S (2002)

TBP dynamics in living human cells: Constitutive association of TBP with mitotic chromosomes.

Mol Biol Cel 13, 276-284

Chuang CF, Running MP, Williams RW and Meyerowitz EM (1999)

The PERIANTHIA gene encodes a bZIP protein involved $\mathrm{n}$ the determination of floral organ number in

Arabidopsis thaliana.

Genes Dev 13, 334-344

Chui WL, Niwa Y, Zeng W, Hirano T, Kobayashi H and Sheen J (1996)

Engineering GFP as a vital reporter in plants.

Curr Biol 6 (3), 325-330

Cody CW, Prasher DC, Westler WM, Prendergast FG and Ward WW (1993)

Chemical structure of the hexapeptide chromophore of the Aequorea victoria green fluorescent protein.

Biochem 32 (5), 1212-1218

Cook PR (1999)

The organization of replication and transcription.

Science 284, 1790-1795

Cubit A, Heim R, Adams S, Boyd A, Gross L and Tsien R (1995)

Understanding, improving and using green fluorescent protein.

TIBS 20, 448-455

Deblaere R, Bytebier B, de Greeve H, Deboeck F, Schell J, van Montagu M and Leemans J (1985)

Efficient octopine Ti-plasmid derived for Agrobacterium-mediated gene transfer.

Nucl Acids Res 13, 4777-4788

DeGiorgi F, Brini M, Bastianutto C, Marsault R, Montero M, Pizzo P et al. (1996)

Targeting aequorin and green fluorescent protein to intracellular organelles.

Gene 173, 113-117

\section{Delaney TP (1997)}

Genetic dissection of acquired resistance in plants.

Plant Physiol 113, 5-12

Dempsey DA, Shah J and Klessig DF (1999)

Salicylic acid and disease resistance in plants.

Crit Rev Plant Sci 18 (4), 547-575

Despres C, DeLong C, Glaze S, Liu E and Fobert PR (2000)

The Arabidopsis NPR1/NIM1 protein enhances the DNA binding activity of a subgroup of the TGA family of bZIP transcription factors.

Plant Cell 12, 279-290

Dower WJ, Miller JF and Ragsdale CW (1988)

High efficiency transformation of $E$. coli with high voltage electroporation.

Nucl Acids Res 16, 6127-6145

Droog F, Spek A, van der Kooy A, de Ruyter A, Hoge H, Libbenga K, Hooykaas P and van der Zaal B (1995)

Promotoranalysis of the auxin-regulated tobacco glutathione-S-transfrerase genes Nt103-1 and Nt103-35.

Plant Mol Biol 29, 413-429 


\section{Durner J, Shah J and Klessig DF (1997)}

Salicylic acid and disease resistance in plants.

Trends Plant Sci 2, 266-274

\section{Ellenberger TE, Brandl CJ, Struhl K and Harrison SC (1992)}

The GCN4 basic region leucine zipper binds DNA as a dimer of uninterrupted alpha helices: Crystal structure of the protein -DNA complex.

Cell 71, 1223-1237

\section{Ellis J and Jones D (1998)}

Structure and function of proteins controlling strain-specific pathogen resistance in plants

Curr Opin Plant Biol 1, 288-293

Elson EL and Madge D (1974)

Fluorescence correlation spectroscopy. I. Conceptual basis and theory.

Biopolymers 13, 1-27

Epel B, Padgett H, Heinlein M and Beachy R (1996)

Plant virus movement protein dynamics probed with a GFP -protein fusion.

Gene 173, 75-79

Fan W and Dong $X$ (2002)

In vivo interaction between NPR1 and transcription factor TGA2 leads to salicylic acid-mediated gene activation in Arabidopsis.

Plant Cell 14, 1-13

\section{Feinberg AP and Vogelstein B (1983)}

A technique for radiolabeling of DNA restriction endonuclease fragments to high specific activity.

Anal Biochem 132, 6-13

Fischer U, Huber J, Boelens WC, Mattaj IW and Luehrmann (1995)

The HIV-1 Rev activation domain is a nuclear export signal that accesses an export pathway used by specific cellular RNAs.

Cell 82, 475-483

\section{Fornerod M, Ohno M, Yoshida M an Mattaj IW (1997)}

CRM1 is an export receptor for leucine-rich nuclear export signals.

Cell 90, 1051-1060

\section{Fromm H, Katagiri F and Chua NH (1989)}

An octopine synthase enhancer element directs tissue-specific expression and binds ASF-1, a factor from tobacco nuclear extracts.

Plant Cell 1, 977-984

\section{Fromm H, Katagiri F and Chua NH (1991)}

The tobacco transcriptional activator TGA1a binds to a sequence in the 5'-upstream region of a gene encoding a TGA1a related protein. Mol Gen Genet 229, 181-188

GaffneyT, Friedrich L, Vernooij B, Negrotto D, Nye G, Uknes S, Ward E, Kessmann H and Ryals J (1993)

Requirement of salicylic acid for the induction of systemic acquired resistance.

Science 261, 754-756 


\section{Garreton V, Carpinelli J, Jordana X and Holuigue L (2002)}

The as-1 promotor element is an oxidative stress-responsive element and salicylic acid activates it via oxidative species.

Plant Physiol 130, 1-11

Haas J, Park EC and Seed B (1996)

Codon usage limitation in the expression of HIV-1 envelope glycoprotein.

Curr Biol 6, 315-324

\section{Hanahan D (1983)}

Studies on transformation of Escherichia coli with plasmids.

J Mol Biol 166, 557-580

\section{Hansen D, Koehler C, Neuhaus G and Merkle T (1999)}

Nuclear export of proteins in plants: AtXPO1 is the export receptor for leucine-rich nuclear export signals in Arabidopsis thaliana

Plant J 20 (6), 695-705

\section{Haseloff J, Siemering KR, Prasher DC and Hodge S (1997)}

Removal of a cryptic intron and subcellular localization of green fluorescent protein are required to mark transgenic Arabidopsis plants brightly.

Proc Natl Acad Sci USA 94, 2122-2127

Heim R, Prasher DC and Tsien RY (1994)

Wavelength mutations and posttranslational autoxidation of green fluorescent protein.

Proc Natl Acad Sci USA 91, 12501 -12504

\section{Heim R, Cubitt AB and Tsien RY (1995)}

Improved green fluorescence.

Nature 373, 663-664

\section{Heim R and Tsien RY (1996)}

Engineering green fluorescent protein for improved brightness, longer wavelengths and fluorescence resonance energy transfer.

Curr Biol 6, 178-182

\section{Hoekema A, Hirsch PR, Hooykaas PJJ and Schilperoort RA (1983)}

A binary plant vector strategy based on separation of vir- and T-region of the Agrobacterium tumefaciens

Ti-plasmid

Nature 303, 179-180

Horsch RB, Fry JE, Hoffmann NL, Eichholtz D, Rogers SG and Fraley RT (1985)

A simple and general method for transferring genes into plants.

Science 227, 1229-1231

\section{Horvath DM and Chua NH (1996)}

Identification of an immediate-early salicylic acid-inducible tobacco gene and characterization of induction by other compounds

Plant Mol Biol 31, 1061-1072

Horvath DM, Huang DJ and Chua NH (1998)

Four classes of salicylate-induced tobacco genes.

Mol Plant Microbe Interact 11, 895-905 
Houtsmuller A, Rademakers S, Nigg AL, Hoogstraten D, Hoeijmakers J H and Vermeulen W (1999) Action of DNA repair endonuclease ERCC1/XPF in living cells. Science 284, 958-961

\section{Houtsmuller A and Vermeulen W (2001)}

Macromolecular dynamics in living cell nuclei revealed by fluorescence redistribution after photobleaching Histochem Cell Biol 115, 13-21

Inoue H, Nojima H and Okayama H (1990)

High efficiency transformation of Escherichia coli with plasmids.

Gene 06, 23-28

Johnson C, Glover G and Arias J (2001)

Regulation of DNA binding and trans-activation by a xenobiotic stress-activated plant transcription factor. J Biol Chem 276 (1), 172-178

Jupin I and Chua NH (1996)

Activation of the CaMV as-1-cis -element by salicylic acid: differential DNA-binding of a factor related to TGA1a.

EMBO J 15 (20), 5679-5689

Kahana J, Schapp B and Silver P (1995)

Kinetics of spindle pole body separation in budding yeast.

Proc Natl Acad Sci USA 92, 9707-9711

\section{Katagiri F, Lam E and Chua NH (1989)}

Two tobacco DNA-binding proteins with homology to the nuclear factor CREB.

Nature 340, 727-730

\section{Katagiri F, Seipel K and Chua NH (1992)}

Identification of a novel dimer stabilization region in a plant bZIP transcription activator

Mol Cell Biol 12 (11), 4809-4816

Kegler C (2001)

Analysis of the transcription factor TGA2.1 from Nicotiana tabacum (in German)

$\mathrm{PhD}$ thesis, Georg-August University - Goettingen, Germany

Kim SR, Kim Y and An G (1993)

Identification of methyl jasmonate and salicylic acid response elements from the nopaline synthase (nos) promotor.

Plant Physiol 103, 97-103

Kinkema M, Fan W and Dong X (2000)

Nuclear localization of NPR1 is required for activation of PR gene expression.

Plant Cell 12, 2339-2350

\section{Kombrink E and Somssich IE (1997)}

Pathogenesis -related proteins and plant defense.

In: Plant Relationships - The Mycota (part A), 107-128

Eds Carroll G and Tudzynski P, Spinger-Verlag, Berlin, Germany

\section{Laemmli UK (1970)}

Cleavage of structural proteins during the assembly of the head of bacteriophage T4.

Nature 227, 680-685 


\section{Lam E, Benfey PN, Gilmartin PM, Fang RX and Chua NH (1989)}

Site-specific mutation alter in vitro factor binding and change promoter expression patterns in transgenic plants.

Proc Natl Acad Sci USA 86, 7890-7894

\section{Lam E and Lam KP (1995)}

Binding site requirements and differential representation of TGA factors in nuclear ASF-1 activity.

Nucl Acids Res 23 (180, 3778-3785

\section{Lam E, Kato $N$ and Lawton $M(2001)$}

Programmed cell death, mitochondria and the plant hypersensitive response.

Nature 411, 848-853

Lamb P and McKnight SL (1991)

Diversity and specificity in transcriptional regulation: the benefits of heterotypic dimerization.

TIBS 16, 417-422

\section{Lamond AI and Earnshaw WC (1998)}

Structure and function in the nucleus.

Science 280, 547-553

\section{Landschulz WH, Johnson PF and McKnight SL (1988)}

The leucine zipper: a hypothetical structure common to a new class of DNA binding proteins.

Science 240, 1759-1764

Le Gouill C, Parent JL, Rola-Pleszczynski M and Stankova J (1994)

Analysis of recombinant plasmids by a modified alkaline lysis method.

Anal Biochem 219, 164.

\section{Lenk I (2001)}

Analysis of the in vivo function of transcription factors TGA2.1 and TGA2.2 from tobacco as fusions with a constitutive activation domain (in German)

$\mathrm{PhD}$ thesis, Georg-August University - Goettingen, Germany

\section{Levine A, Tenhaken R, Dixon R and Lamb C (1994)}

$\mathrm{H}_{2} \mathrm{O}_{2}$ from the oxidative burst orchestrates the plant hypersensitive disease resistance response.

Cell 79, 583-593

\section{Li X, Zhang Y, Clarke JD, Li Y and Dong X (1999)}

Identification and cloning of a negative regulator of systemic acquired resistance, SNI1, through a screen for suppressors of $n p r l-1$.

Cell 98, 329-339

\section{Lim C, Kimata K, Oka M, Nomaguchi K and Kohno K (1995)}

Thermosensitivity of a green fluorescent protein utilized to reveal novel nuclear-like compartments.

J Biochem (Tokyo) 118, 13-17

\section{Litgernik W, Kroj T, zur Nieden U, Hirt H and Scheel D (1997)}

Receptor-mediated activation of a MAP kinase in pathogen defense of plants.

Science 276, 2054-2057

Liu $X$ and Lam E (1994)

Two binding sites for the plant transcription factor ASF-1 can respond to auxin treatment in transgenic tobacco.

J Biol Chem 269, 668-675 
Madge D, Elson E and Web WW (1972)

Thermodynamic fluctuations in a reacting system: measurement by fluorescent correlation spectroscopy. Phys Rev Lett 29, 705-708

\section{Mallamy J, Carr JP, Klessig DF and Raskin I (1990)}

Salicylic acid: a likely endogenous signal in the resistance response of tobacco to viral infection.

Science 250, 1002-1004

\section{Mallamy J, Hennig J and Klessig DF (1992)}

Temperature dependent induction of salicylic acid and its conjugates during the resistance response to tobacco mosaic virus infection.

Plant Cell 4, 359-366

McNally JG, Muller WG, WalkerD, Wolford R and Hager GL (2000)

The glucocorticoid receptor: rapid exchange with regulatory sites in living cells.

Science 287, 1262-1265

\section{Miao ZH and Lam E (1995)}

Construction of a trans-dominant inhibitor for members of the TGA family of transcription factors conserved in higher plants.

Plant J 7 (6), 887-896

Misteli T and Spector DL (1998)

The cellular organization of gene expression.

Curr Opin Cell Biol 10, 322-331

\section{Moores S, Sabry J and Spudich J (1996)}

Myosin dynamics in live Dictiostelium cells.

Proc Natl Acad Sci USA 93, 443-446

Morise H, Shimomura O, Johnson FH and Winant J (1974)

Intermolecular energy transfer in the bioluminescent system of Aequorea.

Biochem 13, 2656-2662

\section{Mullis KB and Faloona FA (1987)}

Specific synthesis of DNA in vitro via a polymerase-catalyzed chain reaction. Methods Enzymol 155, 335-350.

\section{Murashige T and Skoog F(1962)}

A revised medium for rapid growth and bioassays with tobacco tissue culture.

Plant Physiol 15, 473-497.

\section{Nagle JF (1992)}

Long tail kinetics in biophysics?

Biophys J 63, 366-370

Neuhaus G, Neuhaus - Uri G, Katagiri F, Seipel K and Chua NH (1994)

Tissue-specific expression of as-1 in transgenic tobacco.

Plant Cell 6, 827-834

\section{Neville M, Stutz F, Lee L, Davis LI and Rosbach M (1997)}

The importin-beta family member Crm1p bridges the interaction between Rev and the nuclear pore complex during nuclear export.

Curr Biol 7, 767-775 
Niggeweg R (1999)

Salicylic acid - and auxin-inducible gene expression in Nicotiana tabacum. functional role of TGA factors from subclass 2 (in German)

$\mathrm{PhD}$ thesis, University of Bielefeld, Bielefeld, Germany

\section{Niggeweg R, Thurow C, Weigel R, Pfitzner U and Gatz C (2000a)}

Tobacco TGA factors differ with respect to interaction with NPR1, activation potential and DNA-binding properties.

Plant Mol Biol 42, 775-788

\section{Niggerweg $R$, Thurow $C$, Kegler $C$ and Gatz $C$ (2000b)}

Tobacco transcription factor TGA2.2 is the main component of as -1 binding factor AFS -1 and is involved in salicylic acid- and auxin-inducible expression of as-1-containing target promoters.

J Biol Chem 275, 19897-19905

O'Shea EK, Klemm JD, Kim PS and Alber T (1991)

$\mathrm{X}$-ray structure of the GCN4 leucine zipper, a two-stranded parallel coiled coil.

Science 254, 539-544

\section{Odell GT, Nagy F and Chua NH (1985)}

Identification of DNA sequences required for activity of the cauliflower mosaic virus $35 \mathrm{~S}$ promotor. Nature 313, 810-812

\section{Orlando V (2000)}

Mapping chromosomal proteins in vivo by formaldehyde-crosslinked chromatin immunoprecipitation. Trends Biochem Sci 25, 99-103

Ormo M, Cubitt AB, Kallio K, Gross LA, Tsien RY and Remington SJ (1996)

Crystal structure of the Aequorea victoria green fluorescent protein.

Science 273 (5280), 1392-1395

\section{Pascuzzi P, Hamilton D, Bodily K and Arias J (1998)}

Auxin-induced stress potentiates trans-activation by a conserved plant basic/leucine-zipper factor.

J Biol Chem 273 (14), 26631-26637

\section{Peng M and Kuc J (1992)}

Peroxidase-generated hydrogen peroxide as a source of antifungal activity in vitro and on tobacco leaf discs.

Phytopathol 82, 696-699

\section{Phair RD and Misteli T (2000)}

High mobility of proteins in the mammalian cell nucleus.

Nature 404, 604-609

Prasher DC, Eckenrode VK, Ward WW, Prendergast FG and Cormier, MJ (1992)

Primary structure of the Aequorea victoria green fluorescent protein.

Gene 111 (2), 229-233

Prat S, Willmitzer L and Sanches-Serrano JJ (1989)

Nuclear proteins binding to a cauliflower mosaic virus $35 \mathrm{~S}$ truncated promotor

Mol Gen Genet 217, 209-214

\section{Prendergast FG and Mann KG (1978)}

Chemical and physical properties of aequorin and the green fluorescent protein isolated from Aequorea victoria.

Biochem 17, 3448-3453 
Qin XF, Holuiue L, Horvath DM and Chua NH (1994)

Immediate early transcription activation by salicylic acid via the cauliflower mosaic virus $a s$ - 1 element.

Plant Cell 6, 1087-1098

\section{Remington SJ (2000)}

Structural basis for understanding spectral variations in green fluorescent protein.

Meth Enzymol 305, 198-211

\section{Rieping M, Fritz M, Prat S and Gatz C (1994)}

A dominant negative mutant of PG13 suppresses transcription from a cauliflower mosaic virus $35 \mathrm{~S}$ truncated promotor in transgenic tobacco plants.

Plant Cell 6, 1087-1098

\section{Sambrook J, Fritsch EF and Maniatis T (1989)}

Molecular Cloning - A Laboratory Manual (2 $2^{\text {nd }}$ edition).

Cold Spring Harbor Laboratory Press, New York 11724, USA

\section{Sanger F, Nickler S and Coulson AR (1977)}

DNA sequencing with chain-terminating inhibitors.

Proc NatlAcad Sci USA 74, 5463-5467.

\section{Schiermeyer A (2001)}

Cloning and characterization of a new transcription factor of the TGA family from Nicotiana tabacum (in German)

$\mathrm{PhD}$ thesis, Georg-August University - Goettingen, Germany

\section{Schwille P, Korlach J and Webb WW (1999)}

Fluorescence correlation spectroscopy with single molecule sensitivity on cell and model membranes.

Cytometry 36, 176-182

\section{Sheen J (1993)}

Protein phosphatase activity is required for light-inducible gene expression in maize.

EMBO J 12, 3497-3505

Shimomura O, Johnson FH and Saiga Y (1962)

J Cell Comp Physiol 59, 223-239

\section{Shimomura O (1979)}

Structure of the chromophore of Aequorea green fluorescent protein.

FEBS Lett 104, 220-222

\section{Siemering KR, Golbik R, Sever R and Haseloff J (1996)}

Mutations that suppress the thermosensitivity of green fluorescent protein.

Curr Biol 6 (12), 1653-1663

\section{Stange C, Ramirez I, Gomes I, Jordana X and Holuigue L (1997)}

Phosphorilation of nuclear proteins directs binding to salicylic acid-responsive elements.

Plant J 11, 1315-1324

\section{Strompen G, Gruener R and Pfitzner M (1998)}

An as-1-like motif controls the level of expression of the gene for the pathogenesis -related protein 1a from tobacco.

Plant Mol Biol 37, 871-883 
Subramaniam R, Desveaux D, Spickler C, Michnick SW and Brisson N (2001)

Direct visualization of protein interactions in plant cells.

Nature Biotech 19, $769-772$

\section{Sutherland MW (1991)}

The generation of oxygen radicals during host plant responses to infection.

Physiol Mol Plant Pathol 39, 79-93

\section{Thurow C (2001)}

Biochemical purification, functional analysis and identification of interacting partners of the SARP complex from tobacco, involved in salicylic acid -inducible gene expression (in German)

$\mathrm{PhD}$ thesis, Georg-August University - Goettingen, Germany

\section{Tokuhisa JB, Singh K, Dennis ES and Peacock WJ (1990)}

A DNA binding protein factor recognizes two binding domains within the octopine synthase enhancer element.

Plant Cell 2, 215-224

\section{Towbin H, Staehlin T and Gordon $\mathbf{H}$ (1979)}

Electrophoretic transfer of proteins from polyacrylamide gels to nitrocellulose sheets: procedure and some applications.

Proc Natl Acad Sci USA 76, 4350-4354

\section{Tsien RY (1998)}

The green fluorescent protein.

Annu Rev Biochem 67, 509-544

Uknes S, Winter AM, Delaney T, Vernooij B, Morse A, Freidrich L, Nye G, Potter S, Ward E and Ryals J (1993a)

Biological induction of systemic acquired resistance in Arabidopsis.

Mol Plant Microb Interact 6, 692-698

Uknes S, Dincher S, Friedrich L, Negrotto D, Williams S, Thompson-Taylor H, Potter S, Ward E and Ryals J (1993b)

Regulation of pathogenesis-related protein 1a gene expression in tobacco.

Plant Cell 5, 159-169

\section{Ulmasov R, Hagen G and Guifoyle T (1994)}

The ocs element in the soybean GH2/4 promoter is activated by both active and inactive auxin and salicylic acid analogues.

Plant Mol Biol 26, 1055-1064

van der Zaal BJ, Droog FNJ, Pieterse FJ and Hooykaas PJJ (1996)

Auxin-sensitive elements from promotors of tobacco GST genes and a consensus as-1-like element differ only in relative strength.

Plant Physiol 110, 79-88

Verberne MC, Verpoorte R, Bol JF, Mercado-Blanco J and Linthorst HJ (2000)

Overproduction of salicylic acid in plants by bacterial transgenes enhances pathogen resistance.

Nature Biotech 18, 779-783

Wachsmuth M, Waldeck W and Langowski J (2000)

Anomalous diffusion of fluorescent probes inside living cell nuclei investigated by spatially-resolved fluorescence correlation spectroscopy.

J Mol Biol 298, 677-689 


\section{Wang S and Hazelrigg T (1994)}

Implications for $b c d$ mRNA localization from spatial distribution of exu protein in Drosophylla oogenesis. Nature 369, 400-403

\section{Ward WW and Bokman SH (1982)}

Reversible denaturation of Aequorea green fluorescent protein: physical separation and characterization of the renatured protein.

Biochem 21, 4535-4540

Ward ER, Uknes SJ, Williams SC, Dicher SS, Wiederhold DL, Alexander DC, Ahl-Goy P, Metraux J-P and Ryals JA (1991)

Coordinate gene activity in response to agents that induce systemic acquired resistance.

Plant Cell 3, 1085-1094

\section{Weinmann P, Gossen M, Hillen W, Bujard H and Gatz C (1994)}

A chimeric transactivator allows tetracycline-responsive gene expression in whole plants.

Plant J 5 (4), 559-569

\section{Wessel D and Fluegge UI (1984)}

A method for quantitative recovery of proteins in dilute solution in the presence of detergents and lipids.

Anal Biochem 138, 141-143

\section{White RF (1979)}

Acetylsalicylic acid (aspirin) induces resistance to tobacco mosaic virus in tobacco.

Virology 99, 410-412

\section{Xiang C, Miao ZH and Lam E (1996)}

Coordinated activation of as -1-type elements and a tobacco glutathione-S-transferase by auxins, salicylic acid, methyl jasmonate and hydrogen peroxide.

Plant Mol Biol 32, 415-426

Yang F, Moss LG and Phillips GN Jr (1996)

The molecular structure of green fluorescent protein.

Nature Biotech 14 (10), 1246-1256

\section{Yang P, Shah J and Klessig DF (1997)}

Signal perception and transduction in plant defense response.

Genes Dev 11, 1621-1639

Zhou JM, Trifa Y, Silva H, Pontier D, Lam E, Shah J and Klessig DF (2000)

NPR1 differentially interacts with members of the TGA/OBF family of transcription factors that bind an element of the PR-1 gene required for induction with salicylic acid.

Mol Plant Microbe Interact 13 (2), 191-202 
NB only sites of single-cutting restriction nucleases are shown on all maps!!!

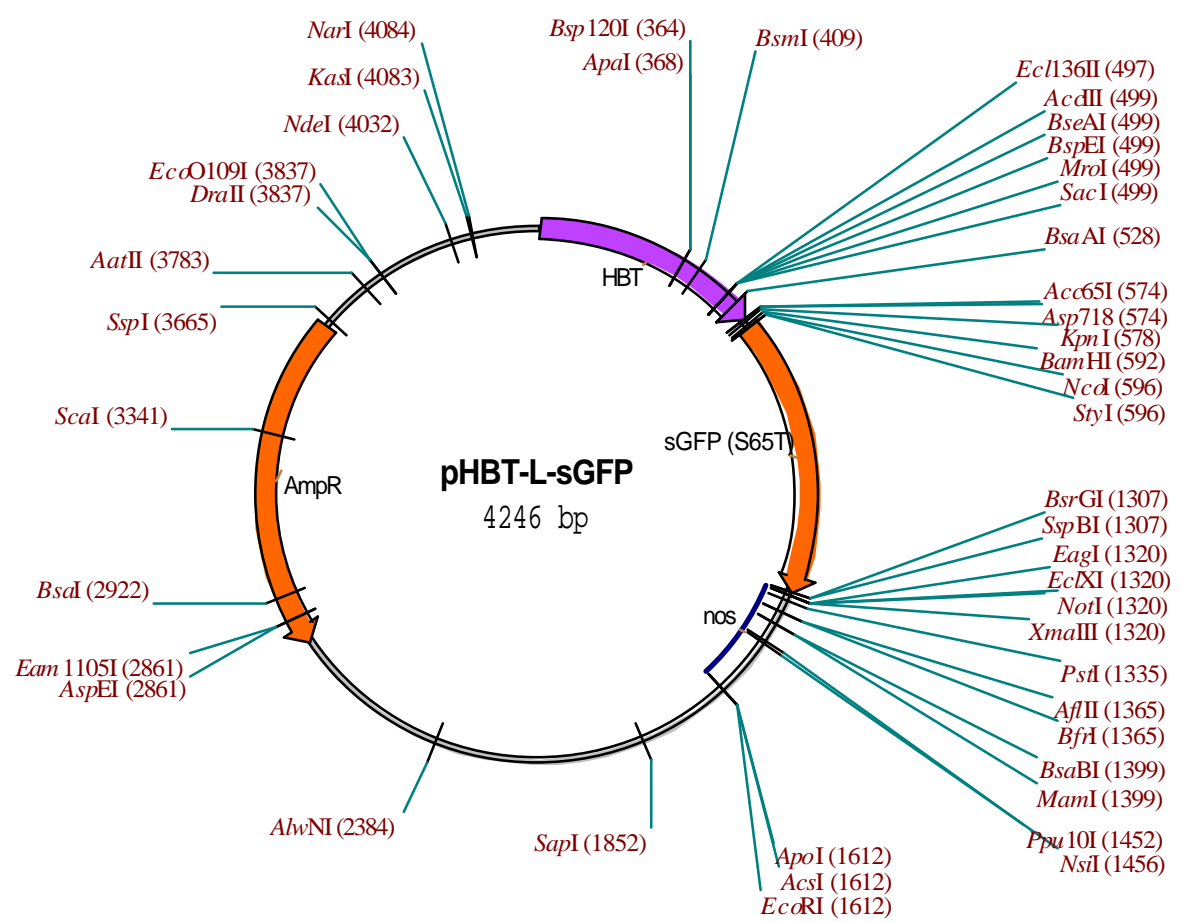

Fig. 8.1. Cloning vector for TGA-GFP fusions (see 3.4.1.2)

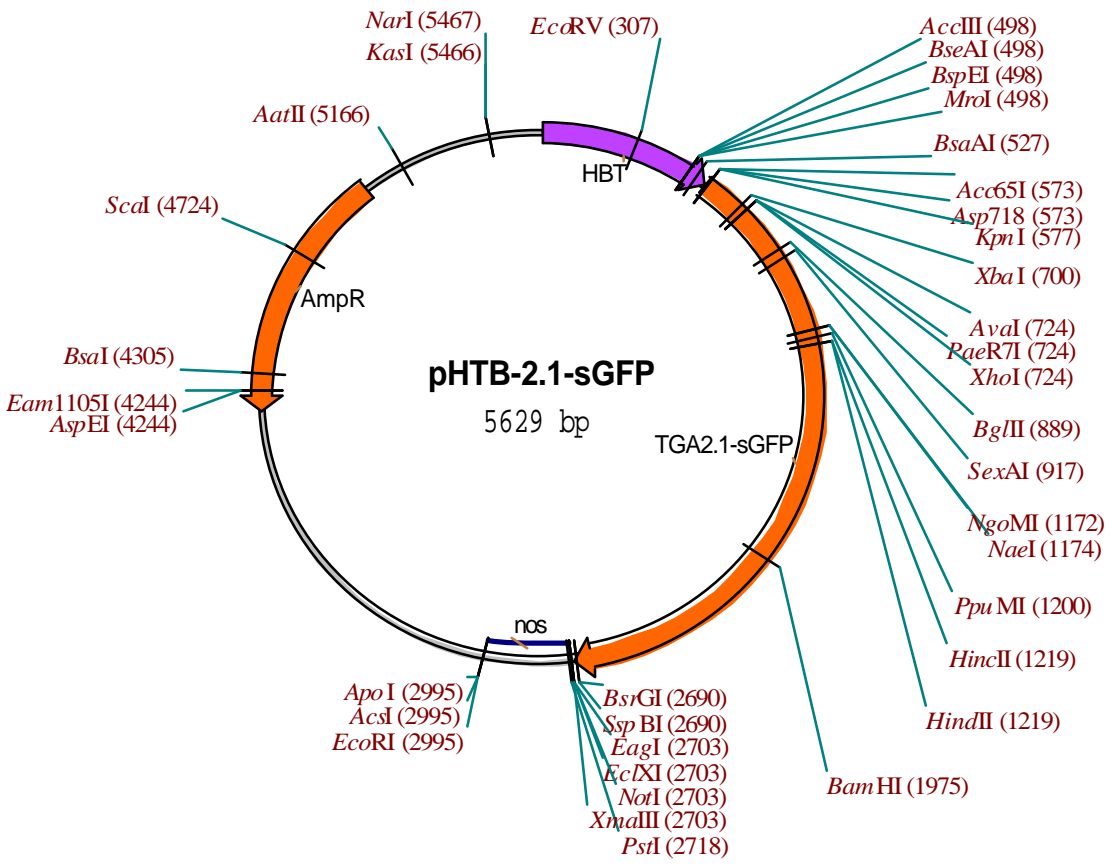

Fig. 8.2. Vector for transient expression of TGA2.1-GFP (see 3.4.1.3) 


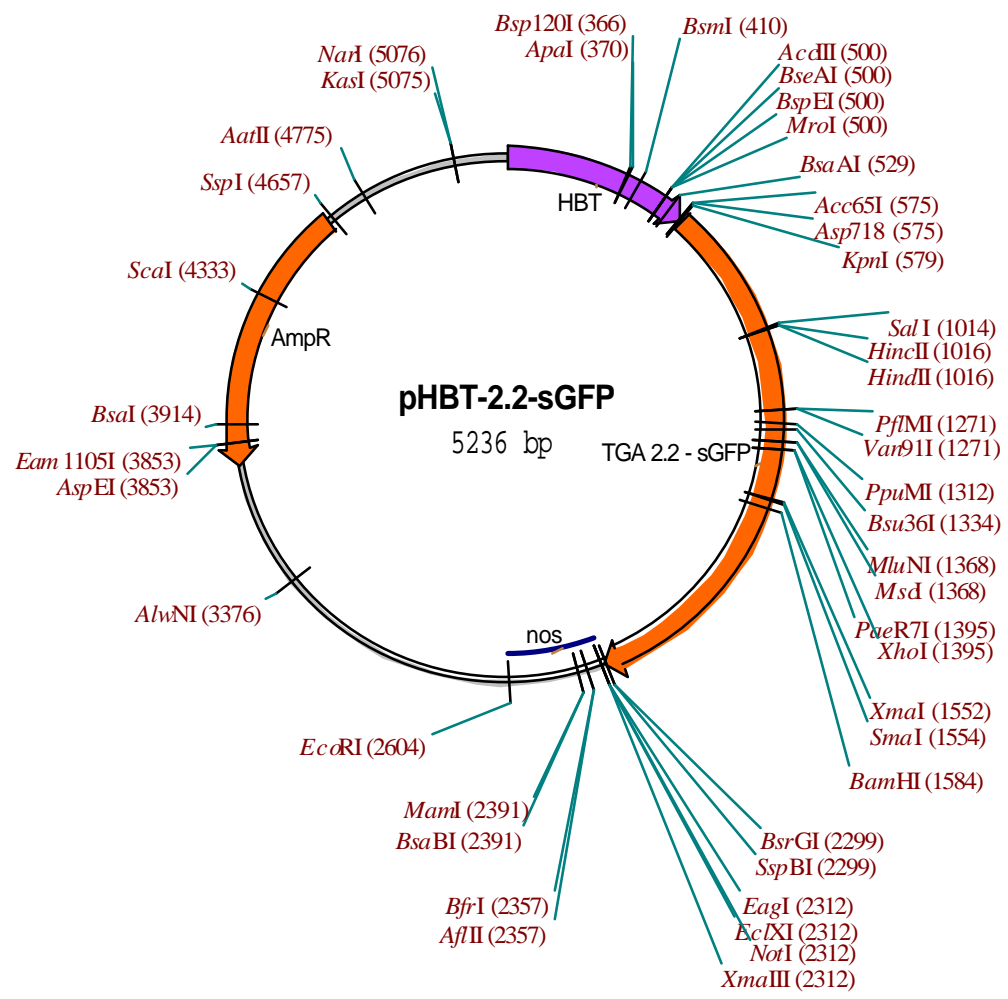

Fig. 8.3. Vector for transient expression of TGA2.2-GFP (see 3.4.1.4)

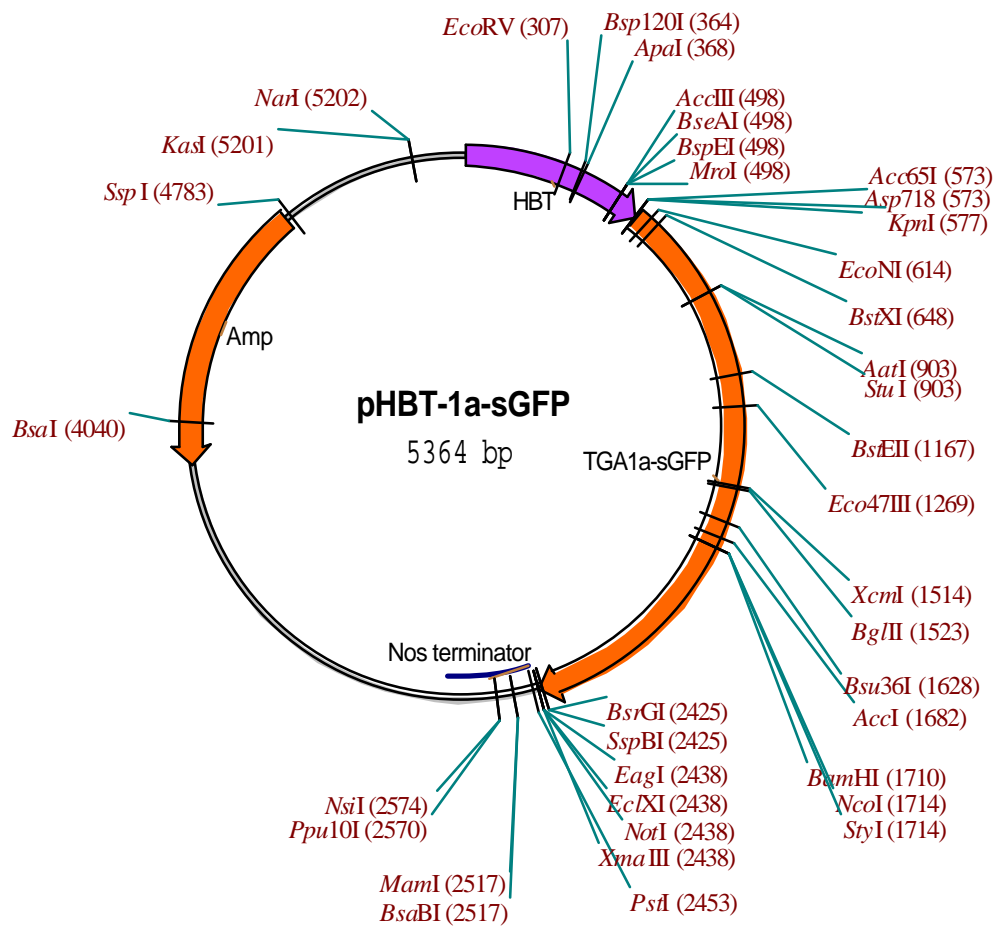

Fig. 8.4. Vector for transient expression of TGA1a-GFP (see 3.4.1.5) 


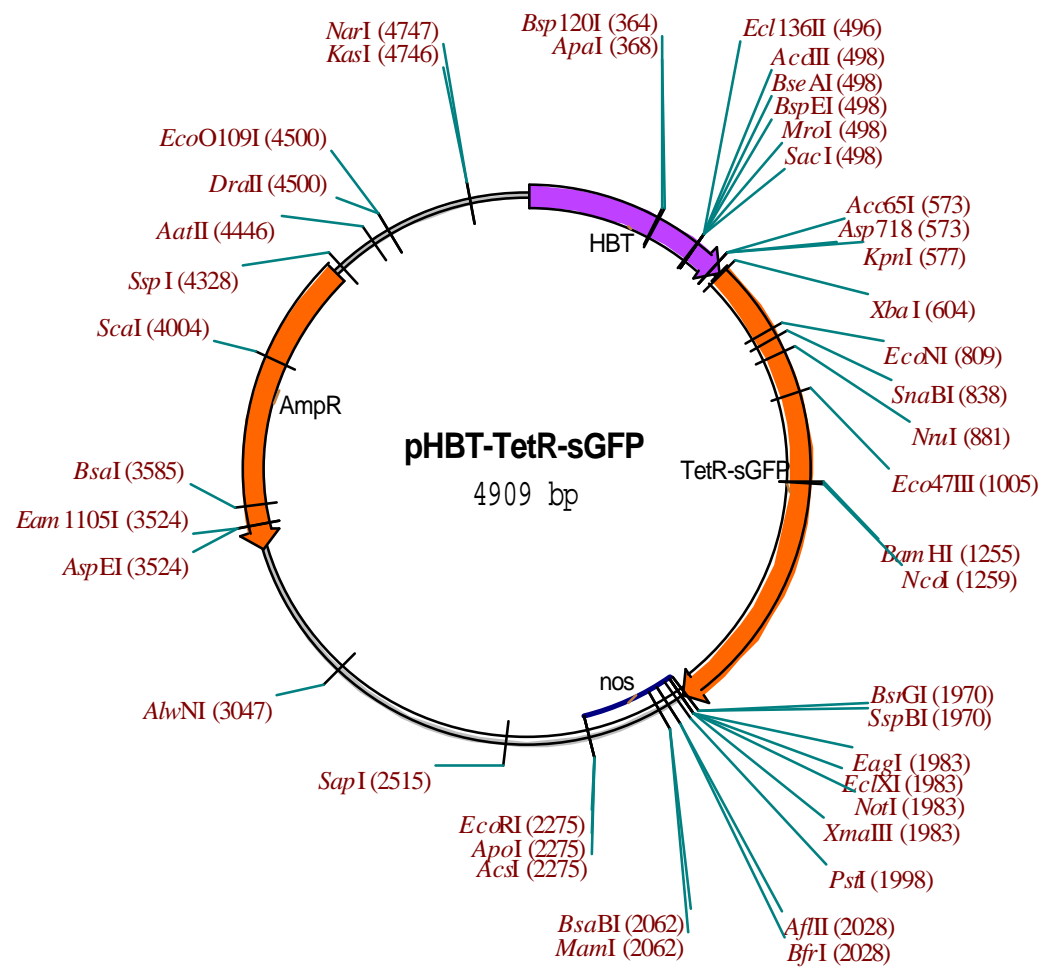

Fig. 8.5. Vector for transient expression of TetR-GFP (see 3.4.1.6)

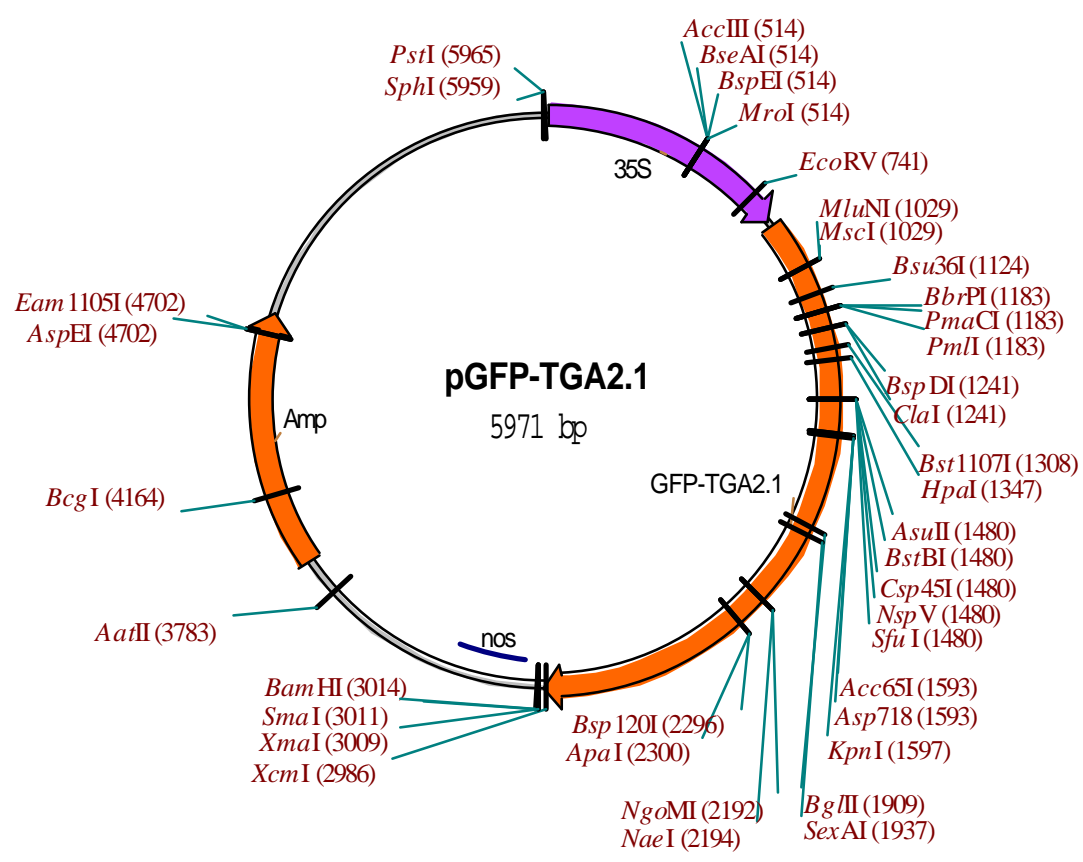

Fig. 8.6. Vector for transient expression of GFP-TGA2.1 (see 3.4.1.) 


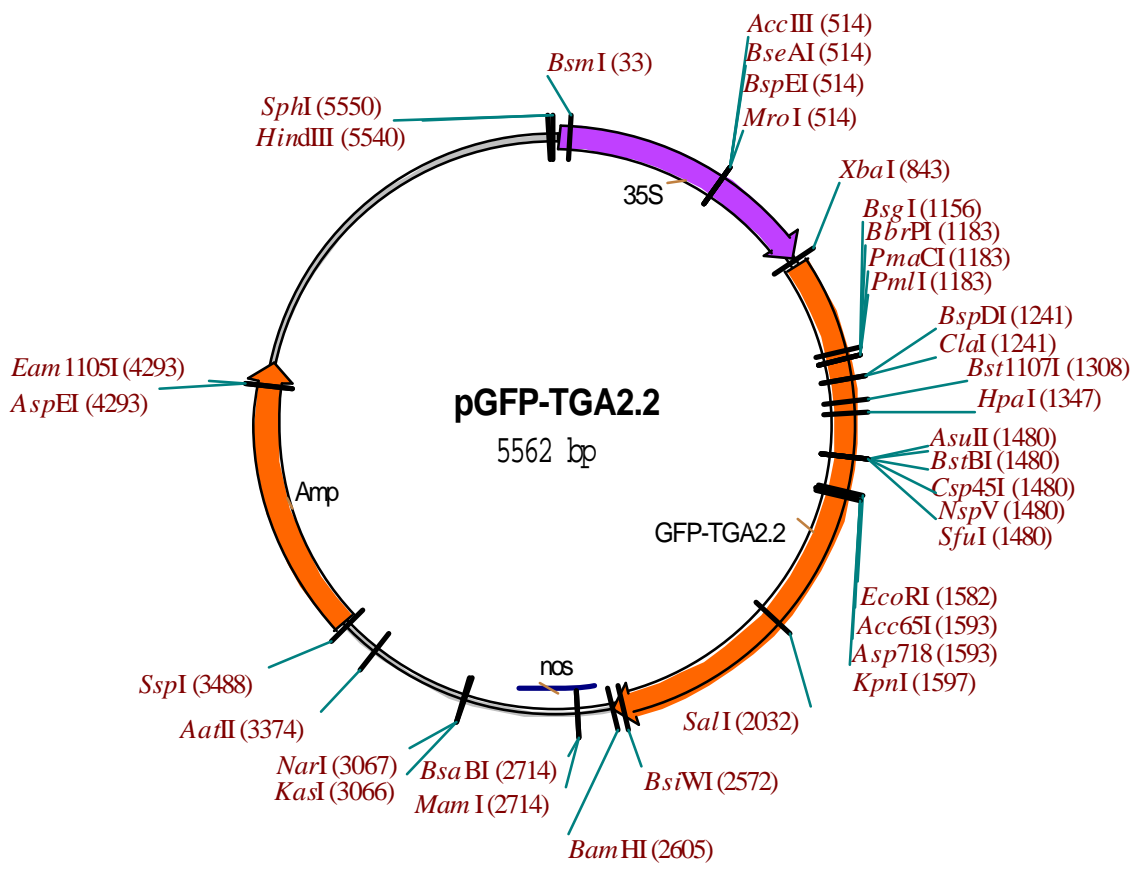

Fig. 8.7. Vector for transient expression of GFP-TGA2.1 (see 3.4.1.)

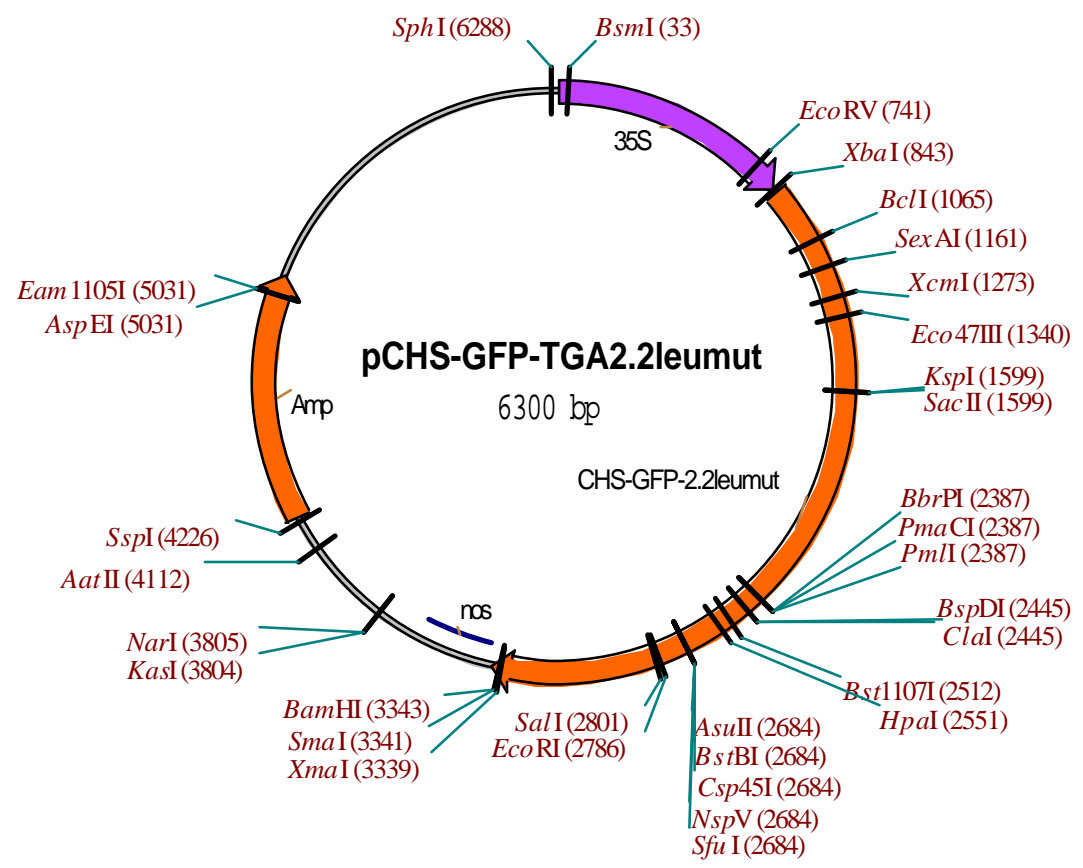

Fig. 8.8. Vector for transient expression of CHS-GFP-TGA2.2-C-LeuMut (see 3.4.1.) 


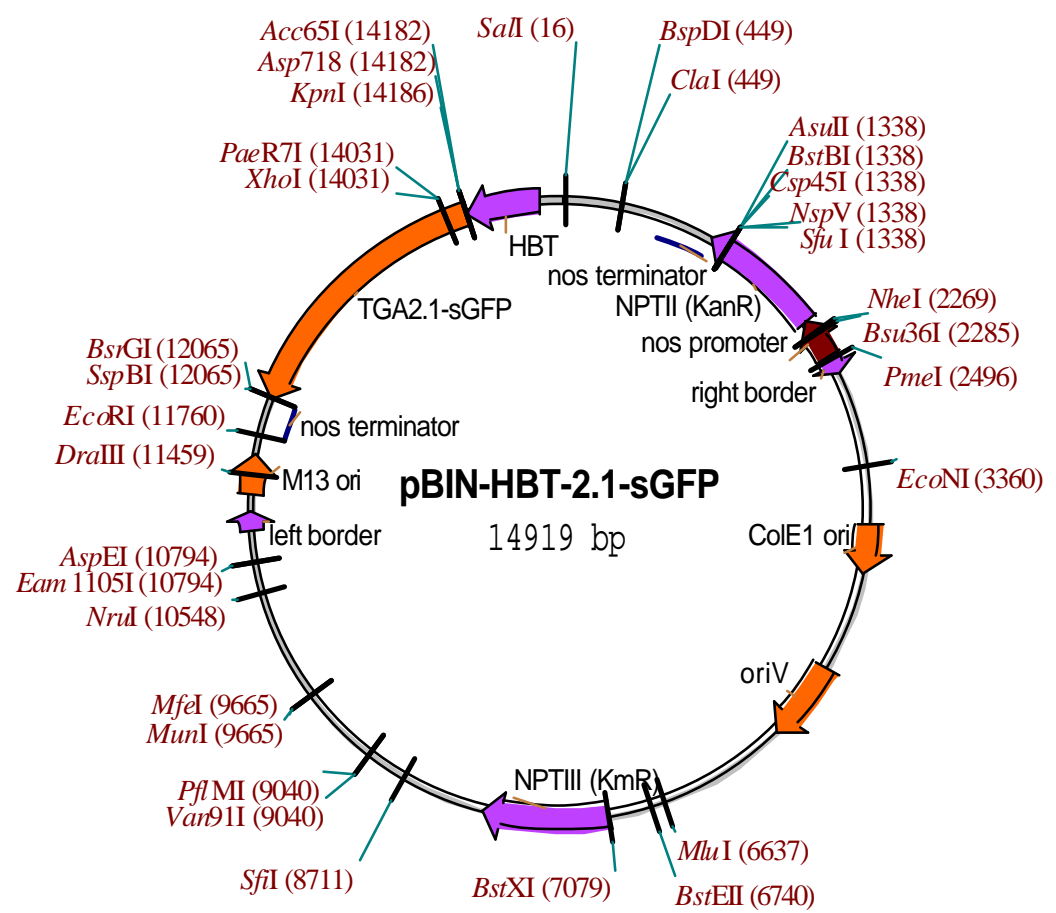

Fig. 8.9. Binary vector for stable transformation of tobacco with HBT::TGA2.1-GFP (see 3.4..)

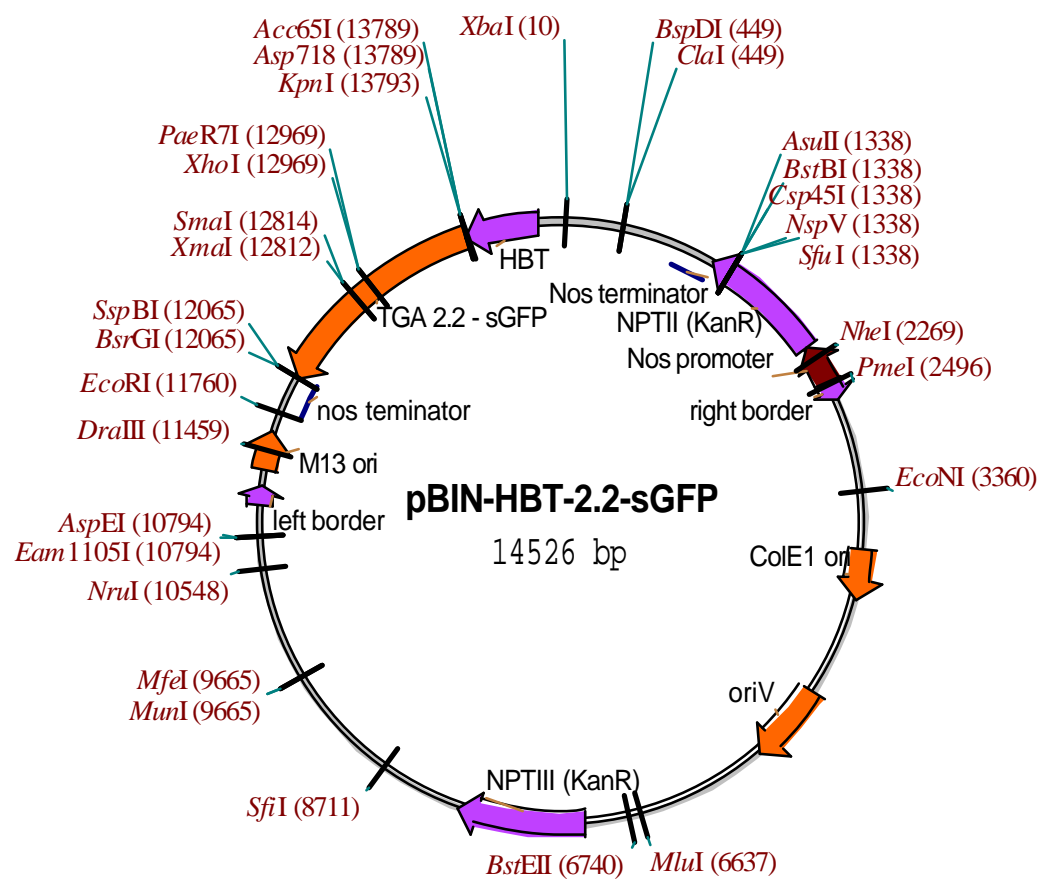

Fig. 8.10. Binary vector for stable transformation of tobacco with HBT::TGA2.2-GFP (see 3.4..) 


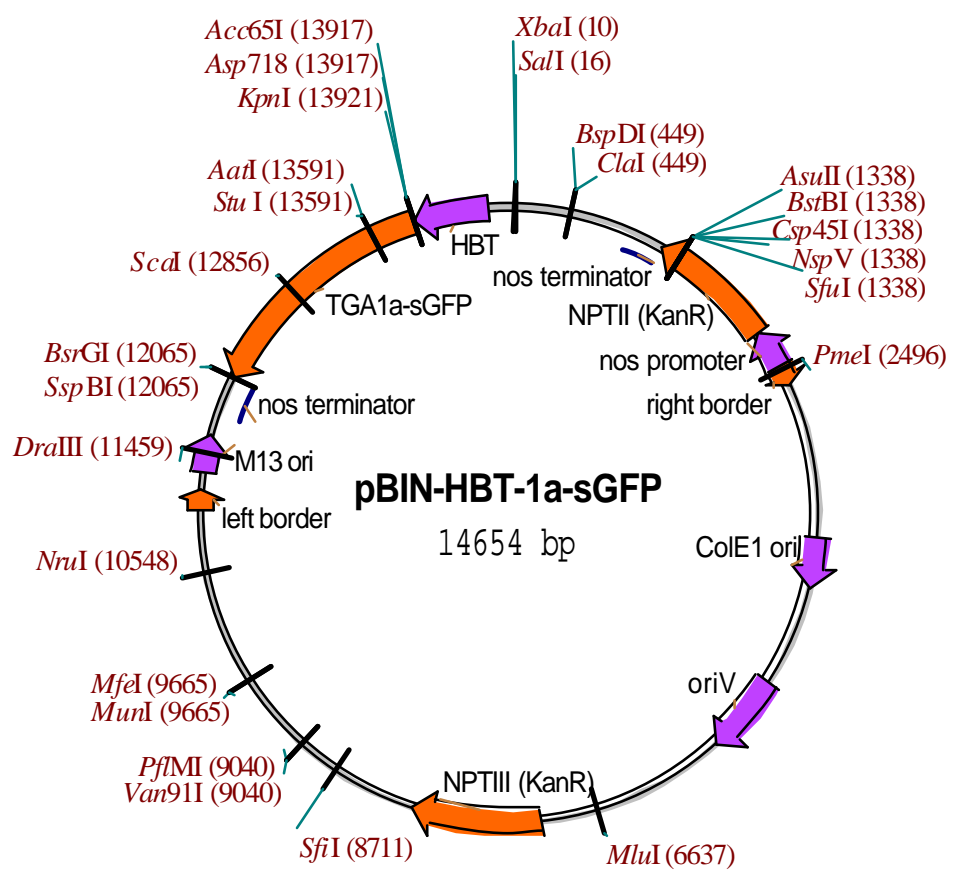

Fig. 8.11. Binary vector for stable transformation of tobacco with HBT::TGA1a-GFP (see 3.4..)

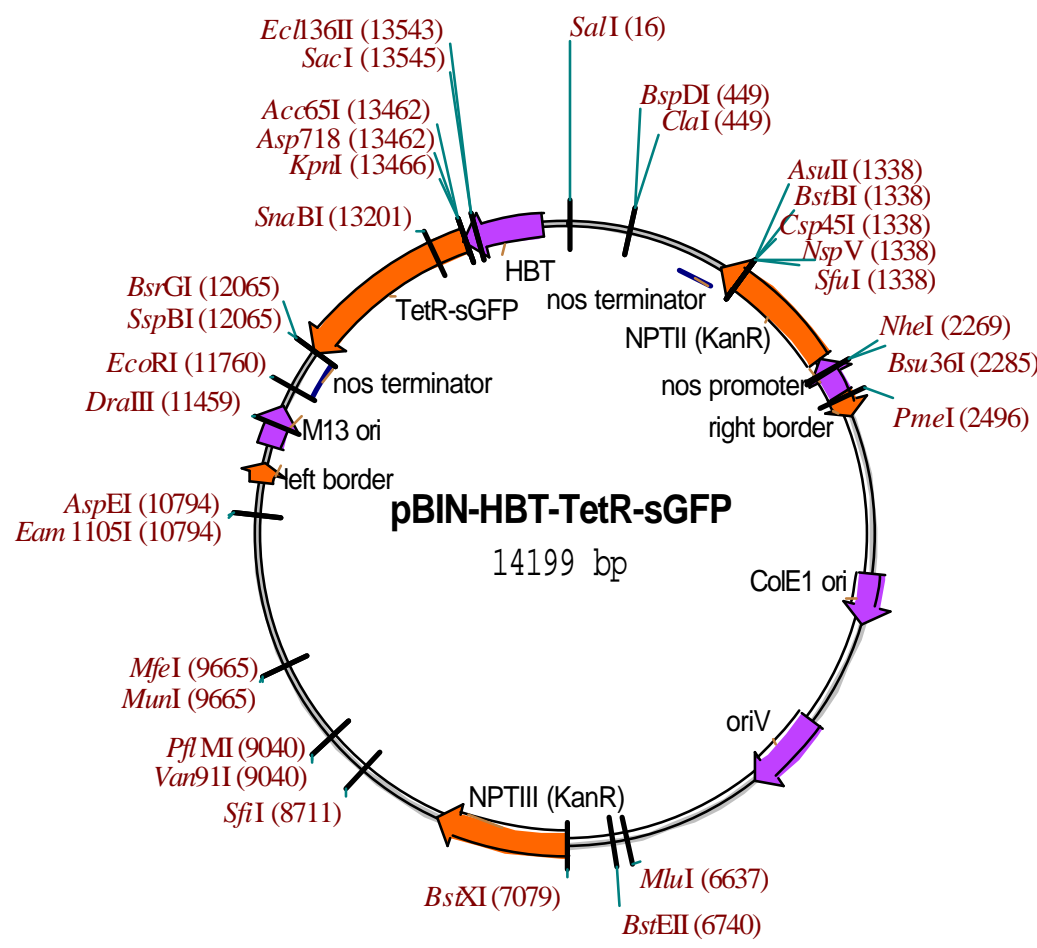

Fig. 8.12. Binary vector for stable transformation of tobacco with HBT::TetR-GFP (see 3.4..) 


\section{Acknowledgements}

I sincerely would like to thank:

- Prof. Dr. C. Gatz for the opportunity to work in her laboratory, for offering this interesting subject for a Ph.D. thesis to me, for the strict supervision of the work and the intense discussions on the progress of the project.

- Prof. Dr. D. Doenecke for accepting me as a member of the postgraduate program, supervised by him, and for all the support during the time.

- Assoc. Prof. Dr. G. Hinz for taking the coreference of this Ph.D. thesis and also for his advices on the methodology of molecular and cell biology.

- Dr. Guido Kriete for helping me in any way possible during the work, and for his deep interest in the project.

- Kirsten Bacia and Dr. Petra Schwille for the possibility to work with FCS, and also for their efforts during the measurements and processing of the data afterwards.

- Dr. Thomas Merkle for the fruitful work together, and the members of his group for the warm acceptance during my short stay in Freiburg.

- all present and former members of the laboratory (the list is quite long) for the friendly cooperation and for the nice attitude towards me both in the lab and in informal activities.

- all my friends (Bulgarian and all other nationalities, the same problem with the list here) in Goettingen and outside for the support and for making my stay here much easier and nicer.

- my family and Elitsa for their loving attitude and patience. 


\section{Curriculum vitae}

- Born on January $10^{\text {th }}, 1972$ in Sofia, Bulgaria; bulgarian citizenship

- September 1978 - July $1986-81^{\text {st }}$ school - Sofia, Bulgaria primary education

- September 1986- July 1991 - $114^{\text {th }}$ English language school - Sofia, Bulgaria secondary education

- June 1991 - graduation examination

- September 1991 - July 1996 - Sofia University "Sveti Kliment Ohridski” student in Biotechnological Processes; specialization Gene and Cell Engineering

- August 1995 - July 1996 - Hospital for Obstetrics and Gynecology - Sofia preparation of the M. Sc. thesis "Linkage analysis of Bipolar and Unipolar affective Disorders with Candidate-Genes in Two Large Pedigrees"

- July 1996 - state examination - defense of the M. Sc. thesis

- September 1996 - September 1997 - military service

- March 1998 - June 1999 - Institute for Plant Physiology - Sofia, Bulgaria research on "Characteristics of the $\mathrm{O}_{2}$-Releasing Complex of Photosystem II"

- June 1999 - December 1999 - Institute for Plant Genetics and Crop Plants Research - Gatersleben, Germany research on "Identification of single-nucleotide polymorphisms (SNPs) in the Wheat Genome"

- January 2000 - December 2002 - Albrecht-von-Haller Institute for Plant Sciences, Goettingen University - Goettingen, Germany

preparation of the present $\mathrm{Ph}$. D. thesis "Subcellular Localization of Nicotiana tabacum TGA Transcription Factors" member of the DFG postgraduate program No. 521 "Protein-Protein Interactions During Intracellular Transport of Macromolecules" 